
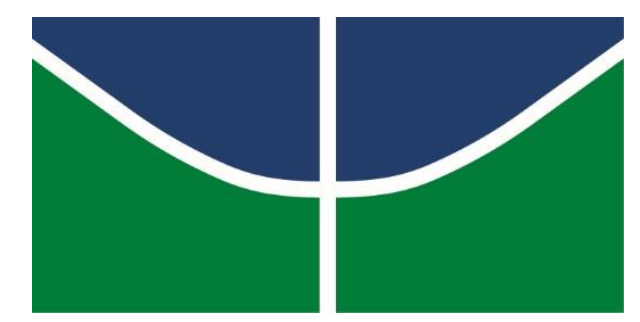

UNIVERSIDADE DE BRASÍLIA

INSTITUTO DE CIÊNCIAS HUMANAS

DEPARTAMENTO DE GEOGRAFIA

PROGRAMA DE PÓS-GRADUAÇÃO EM GEOGRAFIA

MÍDIA IMPRESSA COMO AUXÍLIO À REDUÇÃO DOS RISCOS ASSOCIADOS A DESASTRES NATURAIS NO DISTRITO FEDERAL

LUCAS LIMA COELHO

Orientação: Prof. Dra. Erćilia Torres Steinke

Brasília - DF

Setembro de 2016 
LUCAS LIMA COELHO

MÍDIA IMPRESSA COMO AUXÍLIO À REDUÇÃO DOS RISCOS ASSOCIADOS A DESASTRES NATURAIS NO DISTRITO FEDERAL

Dissertação de Mestrado apresentada ao Programa de Pós-Graduação do Departamento de Geografia (PPGEA) do Instituto de Ciências Humanas $(\mathrm{IH})$ da Universidade de Brasília (UnB) como requisito parcial para obtenção do grau de mestre em Geografia, sob orientação da Prof. Dra. Ercília Torres Steinke.

Brasília - DF

Setembro de 2016 


\section{MÍDIA IMPRESSA COMO AUXÍLIO À REDUÇÃO DOS RISCOS ASSOCIADOS A DESASTRES NATURAIS NO DISTRITO FEDERAL}

Banca examinadora, como consta em ata:

Prof. Dra. Ercília Torres Steinke - orientadora

Departamento de Geografia, Universidade de Brasília

Prof. Dra. Roselir de Oliveira Nascimento

Departamento de Geografia, Universidade de Brasília

Prof. Dr. Luis Alberto Martins Palhares de Melo

Empresa Brasileira de Pesquisa Agropecuária (EMBRAPA)

Brasília - DF

2016 
FICHA CATALOGRÁFICA

COELHO, Lucas Lima.

MÍDIA IMPRESSA COMO AUXÍLIO À REDUÇÃO DOS RISCOS ASSOCIADOS A DESASTRES NATURAIS NO DISTRITO FEDERAL.

Dissertação de mestrado. Universidade de Brasília, Departamento de Geografia, Programa de Pós-graduação em Geografia. Mestrado em Geografia, UnB, 2016.

1. Desastres Naturais

2. Mídia Impressa

3. Impactos Pluviais

4. Climatologia Geográfica

5. Distrito Federal

\section{CESSÃO DE DIREITOS}

AUTOR: Lucas Lima Coelho

TÍTULO: MÍDIA IMPRESSA COMO AUXÍLIO À REDUÇÃO DOS RISCOS ASSOCIADOS A DESASTRES NATURAIS NO DISTRITO FEDERAL

GRAU: Mestrado

ANO: 2016

É concedida à Universidade de Brasília permissão para reproduzir cópias desta dissertação de mestrado e emprestar ou vender tais cópias somente para propósitos ou fins acadêmicos e científicos. O autor reserva outros direitos de publicação e nenhuma parte desta dissertação de mestrado pode ser reproduzida sem autorização por escrito do autor.

Lucas Lima Coelho

Programa de Pós-Graduação em Geografia. Departamento de Geografia. Instituto de Ciências Humanas. Universidade de Brasília, Brasília, Distrito Federal.

Contato: omnilucas@gmail.com 


\section{DEDICATÓRIA}

A Deus, que em meio a todos os percalços sinuosos do processo me deu força para concluir esta dissertação; aos meus pais Jandira e Edilson, que mais uma vez foram fundamentais para que chegasse até aqui; à Heloísa, minha querida irmã, que cuidou de mim; à minha avó Maria e minha tia Janete, pela presença constante na minha vida; à professora Ercília, por todo companheirismo e por não desistir de mim; à minha família, que acreditou em mim; à minha avó Elze Coelho (in memoriam) pelas boas lembranças que deixou; à minha amiga Doralice Rodrigues (in memoriam) pelo carinho que me dedicou; aos meus amigos que me incentivaram a seguir em frente. 


\section{AGRADECIMENTOS}

Primeiramente a Deus, a Deus pela oportunidade de ter estudado, trabalhado e conhecido pessoas maravilhosas na Universidade de Brasília (UnB) e por ter me sustentado mesmo nos momentos mais difíceis;

À minha mãe, minha maior professora, que me ensinou a ser alguém de caráter e abdicou de muitas coisas em sua vida para poder me acompanhar dia após dia;

Ao meu pai, que sempre me incentivou e deu todo o apoio preciso para ingressar na Universidade de Brasília;

À minha irmã, por todo carinho que sempre me dedicou e por ter me ajudado a fazer este trabalho em certos momentos;

À minha avó Maria de Lima e minha tia Janete Oliveira, pelo amor e confiança que depositaram em mim durante todas as fases da minha vida;

À minha família, pelas palavras de carinho;

Aos meus amigos, que de perto ou longe estiveram acompanhando e incentivando minha vida acadêmica;

Aos meus amados irmãos da Igreja Batista Nova Jerusalém, pelas orações e suporte;

À Prof. Dra. Ercília Torres Steinke, minha orientadora querida, por ter me despertado meu interesse para a Climatologia, abrindo as portas do Laboratório de Climatologia Geográfica para que pudesse realizar essa e outras pesquisas;

À Prof. Dra. Roselir de Oliveira Nascimento, pelo incentivo a permanecer estudando ao longo desses anos ("tudo pela ciência") e por aceitar fazer parte da banca examinadora;

Ao Prof. Dr. Luís Alberto Martins Palhares de Melo, pela prestatividade e por aceitar fazer parte da banca examinadora; 
A Elenilson Oliveira, meu professor de Geografia no Ensino Médio, pelo apoio que me prestou em diversos momentos da minha formação e pela inspiração que me deu para cursar Geografia;

A Henrique Von Kriiger e Simoní Hiargles, à época secretários da graduação e pósgraduação em Geografia da UnB respectivamente, que me auxiliaram sobremaneira a ingressar no curso de mestrado e me deram palavras de ânimo quando enfrentei dificuldades.

A Lucas Garcia e Raina Santos, que me ajudaram na elaboração de mapas;

A Hugo César, Rafael Furtado e Raphael Parizotto, que me auxiliaram na recuperação, coleta e sistematização dos dados perdidos da dissertação anterior que foi furtada;

Aos meus amigos do Laboratório de Climatologia Geográfica (LCGea) Hugo Crisóstomo, Igor Taveira e lago Medeiros, que sempre estiveram na torcida por mim; Aos funcionários e estagiários do Departamento de Geografia Agnelo Pereira, Arthur Cavalcante, Bruna, Caio Lemos, Ivano Correia, Jorge Oliveira e Lindalúcia Pereira que sempre foram muito solícitos para comigo;

À Coordenação de Aperfeiçoamento de Pessoal de Ensino Superior (CAPES), pela bolsa de estudos que me bancou financeiramente durante a maior parte do mestrado;

A todos os professores com quem tive a oportunidade de estudar conviver durante minha trajetória escolar e acadêmica, pelo empenho e dedicação para comigo. 
Mas o que quer dizer este poema? - perguntou-me alarmada a boa senhora.

E o que quer dizer uma nuvem? - respondi triunfante. Uma nuvem - disse ela - umas vezes quer dizer chuva, outras vezes bom tempo... Mário Quintana. 


\section{RESUMO}

Desde sua fundação, o Distrito Federal (DF) e suas Regiões Administrativas (RA's), tem passado por um intenso processo de urbanização, o que tem agravado a intensidade de desastres naturais cuja ocorrência é associada ao regime pluviométrico. Nesse contexto, a presente pesquisa pesquisa teve como objetivo identificar e analisar informações referentes aos seguintes desastres naturais: alagamentos, enxurradas, erosões, movimentos de massa, quedas de granizo e vendavais associados a episódios de precipitação entre 2000 e 2010, publicadas na mídia impressa do DF, com a finalidade de consolidar os dados para identificação dos desastres que mais afetam cada Região Administrativa (RA). Para alcançar os objetivos, o trabalho sistematizou notícias diárias do jornal Correio Braziliense e utilizou dados pluviométricos do Instituto Nacional de Meteorologia (INMET) para identificar a ocorrência de desastres naturais relacionados às chuvas na região. Os desastres foram identificados baseados na classificação do Centro de Estudos e Pesquisas em Engenharia e Defesa Civil (CEPED) da Universidade Federal de Santa Catarina (UFSC). Os resultados mostraram que o fator humano é o principal catalisador da ocorrência de desastres naturais no Distrito Federal. Ao todo foram encontrados 439 registros de desastres naturais, sendo 217 ocorrências de alagamentos, 85 de vendavais, 81 de enxurradas, 29 de erosão, 21 de granizo e 6 de movimentos de massa. As Regiões Administrativas mais afetadas foram o Plano Piloto (RA I), com 100 desastres, e Ceilândia (RA IX) com 31 desastres. Foi constatado que as precipitações não são as principais causadoras dos desastres naturais estudados, como é comumente divulgado e observado pela mídia impressa, mas sim que elas favorecem a exposição dos desastres. A técnica utilizada pode servir como ferramenta de planejamento para mitigação da ocorrência de desastres naturais.

Palavras-chave: Desastres Naturais, Mídia Impressa, Impactos Pluviais, Climatologia, Distrito Federal. 


\begin{abstract}
The Distrito Federal (DF) and its Administrative Regions (RA's in Portuguese), since its foundation, has undergone an intense process of urbanization, which has aggravated the intensity of natural disasters whose occurrence is associated with the pluviometric regime. In this context, this research study aimed to identify and analyze information relating to the following natural disasters: floods, flash floods, erosions, mass movements, hail-storms and gales associated with episodes of rainfall between 2000 and 2010, published in the press media DF, with the purpose of consolidating the data to identify the disasters that most affect each Administrative Region (RA). In order to reach the objectives, the work systematized daily news from the Correio Braziliense newspaper and used pluviometric data from the National Institute of Meteorology (INMET) to identify the occurrence of natural disasters related to rainfall in the region. The disasters were identified based on the classification of the Center for Studies and Research in Engineering and Civil Defense (CEPED) of the Federal University of Santa Catarina (UFSC). The results showed that the human factor is the main catalyst for the occurrence of natural disasters in the Distrito Federal. Altogether, 439 records of natural disasters were found, with 217 occurrences of flooding, 85 of gales, 81 of flash floods, 29 of erosion, 21 of hail-storms and 6 of mass movements. It was verified that rainfall is not the main cause of the natural disasters studied, as is commonly reported and observed in the press media, but they favor the exposure of disasters. The technique used can serve as a planning tool to mitigate the occurrence of natural disasters.
\end{abstract}

Key-Words: Natural Disasters, Press Media, Pluvial Impacts, Climatology, Distrito Federal. 


\section{SUMÁRIO}

Pág.

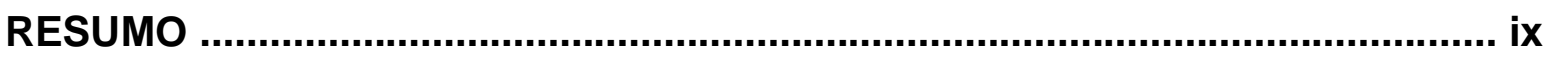

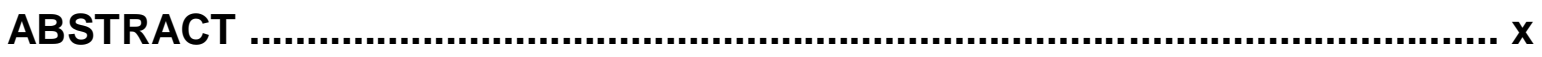

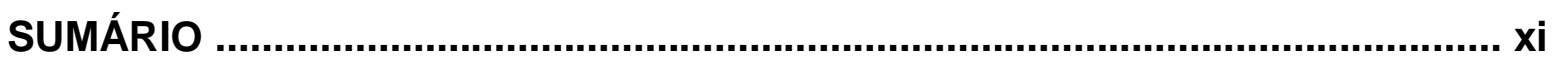

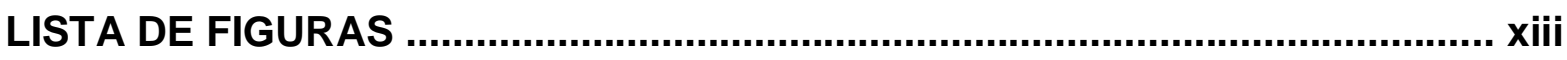

LISTA DE GRÁFICOS, QUADROS E TABELAS LISTA DE FIGURAS

LISTA DE ABREVIATURAS, SIGLAS E SÍMBOLOS ..................................... xxi

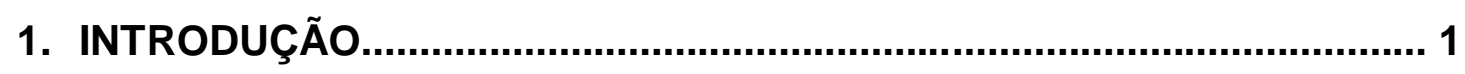

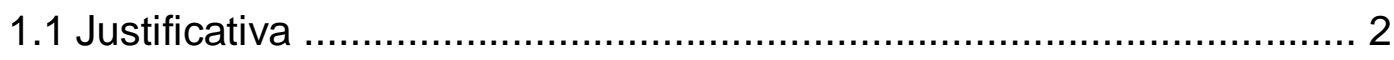

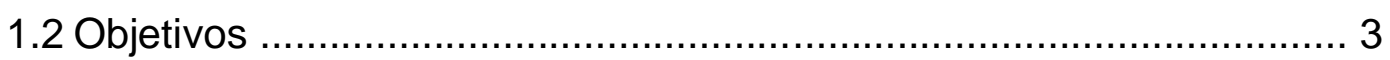

1.2.1.1 Objetivo Geral............................................................ 3

1.2.1.2 Objetivos Específicos.................................................. 3

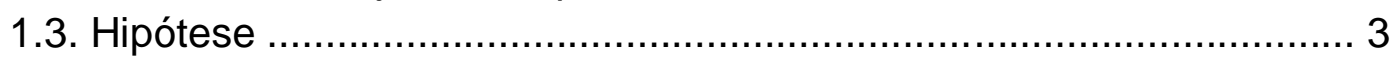

2. REFERENCIAL TEÓRICO ….......................................................... 4

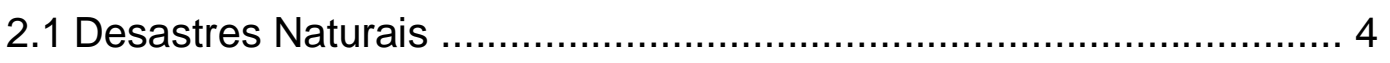

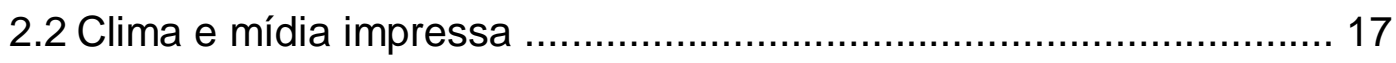

2.2.1. Clima e mídia impressa no mundo.......................................... 17

2.2.2. Clima e mídia impressa no Brasil............................................ 24

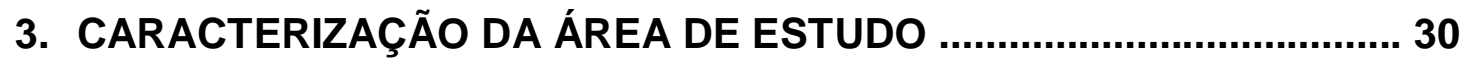

3.1. Histórico da ocupação do Distrito Federal ..................................... 30

3.2. Localização e delimitação da área de estudo ................................. 35

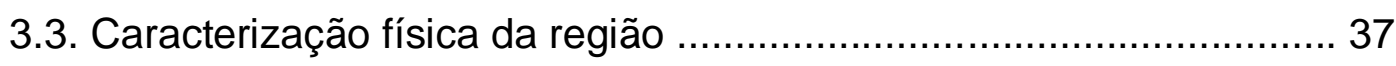

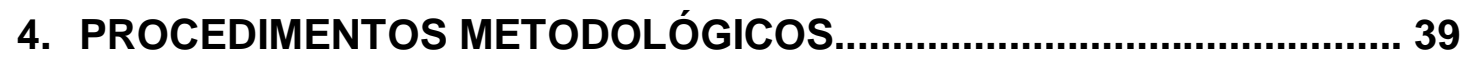

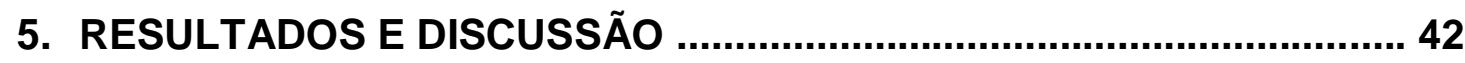

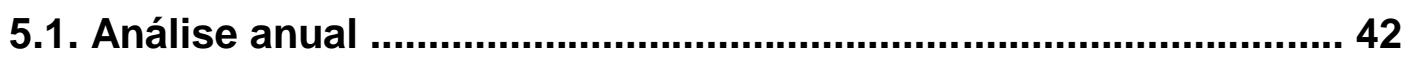

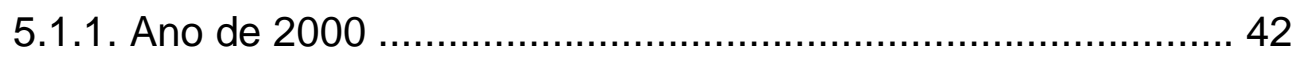




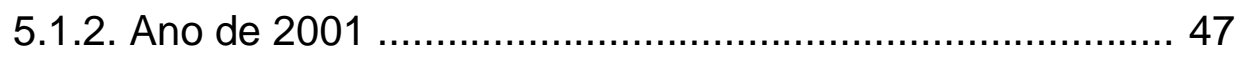

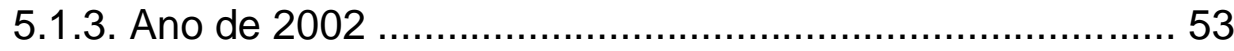

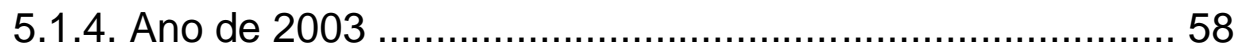

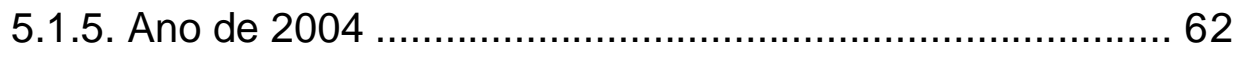

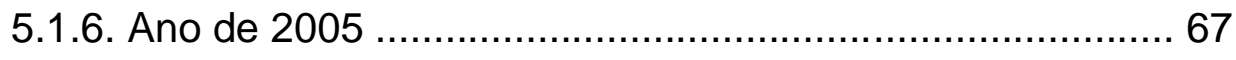

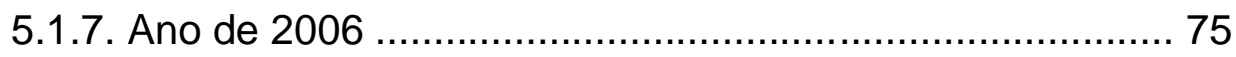

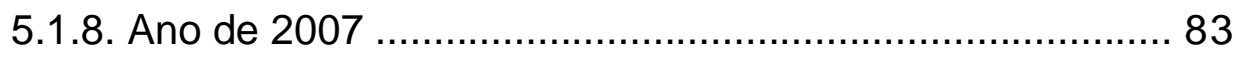

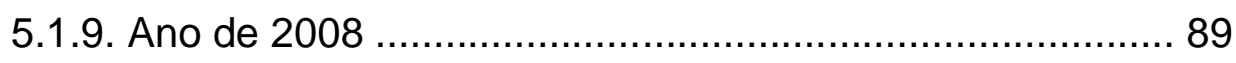

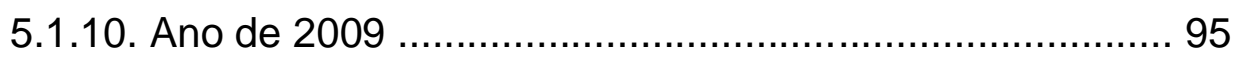

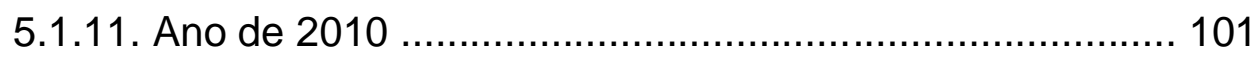

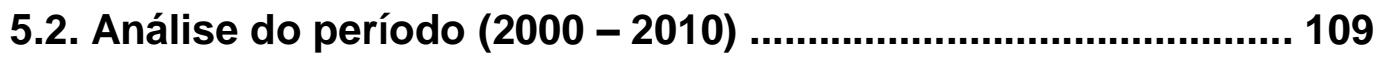

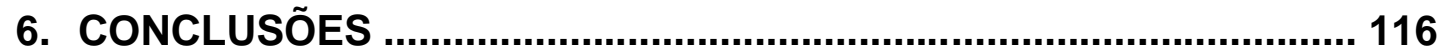

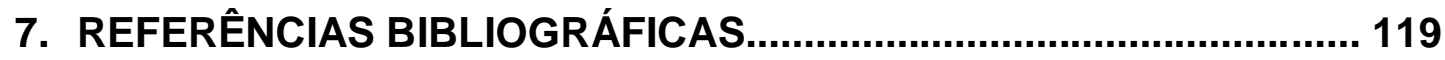

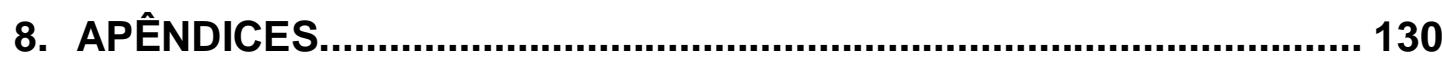




\section{LISTA DE FIGURAS}

Pág.

Figura 1. Cartograma do número de desastres naturais por país no período de 1976 a 2005.

6

Figura 2. Cartograma da ocorrência de desastres naturais em 2010 por país.

Figura 3. Cartograma do número mortes e pessoas afetadas por desastres naturais por país no período de 1976 a 2005.

Figura 4. Cartograma do número de pessoas afetadas por desastres naturais em 2010 por país

Figura 5. Número de ocorrências de alagamentos por país no período de 1974 a 2003.

Figura 6. Número de ocorrências de alagamentos por país no período de 1974 a 2003.

Figura 7. Mapa das Regiões Administrativas do Distrito Federal em sua atual configuração.

Figura 8. Organograma da dissertação.

Figura 9. Mapa de distribuição das estações meteorológicas do INMET no DF

Figura 10. Recorte de reportagem de janeiro de 2000.

Figura 11. Recorte de reportagem de fevereiro de 2000.

Figura 12. Recorte de reportagem de janeiro de 2001.

Figura 13. Recorte de reportagem de março de 2001.

Figura 14. Recorte de reportagem de dezembro de 2002.

Figura 15. Recorte de reportagem de fevereiro de 2004.

Figura 16. Recorte de reportagem de fevereiro de 2004.

Figura 17. Recorte de reportagem de março de 2005.

Figura 18. Recorte de reportagem de março de 2005.

Figura 19. Recorte de reportagem de março de 2005. 
Figura 20. Recorte de reportagem de fevereiro de 2006.

Figura 21. Recorte de reportagem de março de 2006.

Figura 22. Recorte de reportagem de outubro de 2006.

Figura 23. Recorte de reportagem de março de 2007.

Figura 24. Recorte de reportagem de novembro de 2007.

Figura 25. Recorte de reportagem de março de 2007.

Figura 26. Recorte de reportagem de fevereiro de 2008.

Figura 27. Recorte de reportagem de outubro de 2008.

Figura 28. Recorte de reportagem de janeiro de 2009.

Figura 29. Recorte de reportagem de abril de 2009.

Figura 30. Recorte de reportagem de novembro de 2010.

Figura 31. Recorte de reportagem de março de 2010.

Figura 32. Recorte de reportagem de outubro de 2010

Figura 33. Mapa da ocorrência de alagamentos por Região Administrativa no período de 2000 a 2010.

Figura 34. Mapa da ocorrência de enxurradas por Região Administrativa no período de 2000 a 2010.

Figura 35. Mapa da ocorrência de erosão por Região Administrativa no período de 2000 a 2010.

Figura 36. Mapa da ocorrência de granizo por Região Administrativa no período de 2000 a 2010.

Figura 37. Mapa da ocorrência de movimentos de massa por Região Administrativa no período de 2000 a 2010.

Figura 38. Mapa da ocorrência de vendavais por Região Administrativa no período de 2000 a 2010. 


\section{LISTA DE GRÁFICOS, QUADROS E TABELAS}

Pág.

Gráfico 1. Porcentagem de Desastres naturais no Brasil no período entre 1991 e 2012.

Gráfico 2. Frequência anual de desastres naturais ocorridos no Brasil entre 1991 e 2012.

Gráfico 3. Comparação entre os desastres naturais ocorridos no período 1991-2011 e no período 2002-2012.

Gráfico 4. Evolução histórica dos desastres naturais ocorridos no Brasil entre 1991 e 2012.

Gráfico 5. Comparativo de ocorrência de tipo de desastres ocorridos por ano no período 1991-2012.

Gráfico 6. Porcentagem de pessoas afetadas por desastres naturais por tipo de desastre.

Gráfico 7. Número de artigos publicados com as palavras-chave climate (clima) e press media (mídia impressa) em periódicos com fator de impacto $>1$ na plataforma Web of Science.

Gráfico 8. Variação anual do total mensal de precipitação e da média mensal da temperatura do ar no Distrito Federal no período de 1961 a 1990.

Gráfico 9. Precipitação mensal acumulada em 2000 na Estação Brasília do INMET (DF).

Gráfico 10. Precipitação mensal acumulada em 2000 na Estação Roncador do INMET (DF).

Gráfico 11. Número de reportagens encontradas mensalmente em 2000. Fonte dos dados: Correio Braziliense.

Gráfico 12. Porcentagem de desastres naturais encontrados nas reportagens ocorridos em 2000.

Gráfico 13. Precipitação mensal acumulada em 2001 na Estação Brasília do INMET (DF).

Gráfico 14. Precipitação mensal acumulada em 2001 na Estação Roncador do INMET (DF). 
Gráfico 15. Número de reportagens encontradas mensalmente em 2001.

Gráfico 16. Porcentagem de desastres naturais encontrados nas reportagens ocorridos em 2001.

Gráfico 17. Precipitação mensal acumulada em 2002 na Estação Brasília do INMET (DF).

Gráfico 18. Precipitação mensal acumulada em 2002 na Estação Roncador do INMET (DF).

Gráfico 19. Número de reportagens encontradas mensalmente em 2002.

Gráfico 20. Porcentagem de desastres naturais encontrados nas reportagens ocorridos em 2002.

Gráfico 21. Precipitação mensal acumulada em 2003 na Estação Brasília do INMET (DF).

Gráfico 22. Precipitação mensal acumulada em 2003 na Estação Roncador do INMET (DF).

Gráfico 23. Número de reportagens encontradas mensalmente em 2003.

Gráfico 24. Porcentagem de desastres naturais encontrados nas reportagens ocorridos em 2003

Gráfico 25. Precipitação mensal acumulada em 2004 na Estação Brasília do INMET (DF).

Gráfico 26. Precipitação mensal acumulada em 2004 na Estação Roncador do INMET (DF).

Gráfico 27. Número de reportagens encontradas mensalmente em 2004.

Gráfico 28. Porcentagem de desastres naturais encontrados nas reportagens ocorridos em 2004.

Gráfico 28. Precipitação mensal acumulada em 2005 na Estação Brasília do INMET (DF).

Gráfico 29. Precipitação mensal acumulada em 2005 na Estação Roncador do INMET (DF). 
Gráfico 30. Número de reportagens encontradas mensalmente em 2005.

Gráfico 31. Porcentagem de desastres naturais encontrados nas reportagens ocorridos em 2005.

Gráfico 32. Precipitação mensal acumulada em 2006 na Estação Brasília do INMET (DF).

Gráfico 33. Precipitação mensal acumulada em 2006 na Estação Roncador do INMET (DF).

Gráfico 34. Número de reportagens encontradas mensalmente em 2006.

Gráfico 35. Porcentagem de desastres naturais encontrados nas reportagens ocorridos em 2006.

79

Gráfico 36. Precipitação mensal acumulada em 2007 na Estação Brasília do INMET (DF).

Gráfico 37. Precipitação mensal acumulada em 2007 na Estação Roncador do INMET (DF).

Gráfico 38. Número de reportagens encontradas mensalmente em 2007.

Gráfico 39. Porcentagem de desastres naturais encontrados nas reportagens ocorridos em 2007.

Gráfico 40. Precipitação mensal acumulada em 2008 na Estação Brasília do INMET (DF).

Gráfico 41. Precipitação mensal acumulada em 2008 na Estação Roncador do INMET (DF).

Gráfico 42. Número de reportagens encontradas mensalmente em 2008.

Gráfico 43. Porcentagem de desastres naturais encontrados nas reportagens ocorridos em 2008.

Gráfico 44. Precipitação mensal acumulada em 2009 na Estação Brasília do INMET (DF).

Gráfico 45. Precipitação mensal acumulada em 2009 na Estação Roncador do INMET (DF). 
Gráfico 46. Número de reportagens encontradas mensalmente em 2009.

Gráfico 47. Porcentagem de desastres naturais encontrados nas reportagens ocorridos em 2008

Gráfico 48. Precipitação mensal acumulada em 2010 na Estação Brasília do INMET (DF).

Gráfico 49. Precipitação mensal acumulada em 2010 na Estação Roncador do INMET (DF).

Gráfico 50. Número de reportagens encontradas mensalmente em 2009.

Gráfico 51. Porcentagem de desastres naturais encontrados nas reportagens ocorridos em 2010.

Quadro 1. Quadro de crescimento da população no Distrito Federal conforme censos demográficos realizados.

Quadro 2. Número de reportagens encontradas mensalmente em 2000 com tipologia de desastres naturais.

Quadro 3. Número de reportagens encontradas mensalmente em 2001 com tipologia de desastres naturais.

Quadro 4. Número de reportagens encontradas mensalmente em 2002 com tipologia de desastres naturais.

Quadro 5. Número de reportagens encontradas mensalmente em 2003 com tipologia de desastres naturais.

Quadro 6. Número de reportagens encontradas mensalmente em 2004 com tipologia de desastres naturais.

Quadro 7. Número de reportagens encontradas mensalmente em 2005 com tipologia de desastres naturais.

Quadro 8. Número de reportagens encontradas mensalmente em 2006 com tipologia de desastres naturais

Quadro 9. Número de reportagens encontradas mensalmente em 2007 com tipologia de desastres naturais.

Quadro 10. Número de reportagens encontradas mensalmente em 2008 com tipologia de desastres naturais. 
Quadro 11. Número de reportagens encontradas mensalmente em 2009 com tipologia de desastres naturais.

Quadro 12. Número de reportagens encontradas mensalmente em 2009 com tipologia de desastres naturais. 


\section{LISTA DE ABREVIATURAS, SIGLAS E SÍMBOLOS}

$\%$

Porcentagem

$\S$

Inciso

$\stackrel{\circ}{ } \mathrm{C}$

Temperatura em Graus Celsius

Art.

Artigo

BR

Rodovia federal

BID

Banco Interamericano de Desenvolvimento

CEASA

Centrais de Abastecimento do Distrito Federal

CEB

Companhia Energética de Brasília

CNUMAD

Conferência das Nações Unidas sobre o

Meio Ambiente e o Desenvolvimento

CODEPLAN

Companhia de Planejamento do Distrito Federal

CAESB

Companhia de Saneamento Ambiental do Distrito Federal

CPTEC

Centro de Previsão de Tempo e Estudos Climáticos

CSN

Companhia Siderúrgica Nacional

DETRAN

Departamento Estadual de Trânsito

DF

Distrito Federal

DFTrans

Transporte Urbano do Distrito Federal

DER

Departamento de Estradas e Rodagem

DNER

Departamento Nacional de Estradas e Rodagem

DNIT

Departamento Nacional de Infraestruturas Terrestres

ENOS

El Niño - Oscilação Sul

EPIA

Estrada Parque Indústria e Abastecimento

EPTG

Estrada Parque Taguatinga-Guará

ETE

Estação de Tratamento de Esgoto

h.

Horas 
IBAMA Instituto Brasileiro do Meio Ambiente e dos Recursos Naturais IBGE Instituto Brasileiro de Geografia e Estatística INMET Instituto Nacional de Meteorologia INPE Instituto Nacional de Pesquisas Espaciais IPCC Painel Intergovernamental sobre Mudanças Climáticas IPHAN Instituto do Patrimônio Histórico e Artístico Nacional $\mathrm{JK}$ Juscelino Kubitschek

$\mathrm{mm}$ Milímetros (precipitação)

$\mathrm{mEc}$ Massa Equatorial Continental

$\mathrm{mTa}$ Massa Tropical Atlântica NOVACAP Companhia Urbanizadora da Nova Capital do Brasil

$\mathrm{OMM}$ Organização Meteorológica Mundial

ONU Organização das Nações Unidas

PNUMA Programa das Nações Unidas para o Meio Ambiente RA Região Administrativa do Distrito Federal SEBRAE Serviço Brasileiro de Apoio às Micro e Pequenas Empresas SCIA Setor Complementar de Indústria e Abastecimento

SIA Setor de Indústria e Abastecimento

SIG Setor de Indústrias Gráficas

SIV-Água Sistema Integrado de Vigilância, Preservação e Conservação de Mananciais

Trim. Trimestre

UnB Universidade de Brasília UFG Universidade Federal de Goiás 


\section{INTRODUÇÃO}

Nos últimos anos, os desastres de origem meteorológica e climática têm sido observados numa grande frequência ao redor do mundo (Marcelino, Nunes e Kobiyama, 2006; Armond, 2014). Com as dinâmicas sociais se sobrepondo às dinâmicas naturais, por meio de processos como a urbanização, a situação da sociedade frente aos desastres tem se agravado, 0 que dificulta a sua recuperação (Fialho, 2013).

As melhorias tecnológicas da segunda metade do século XX permitiram um grande avanço no monitoramento dos fenômenos climáticos. Dessa maneira, pesquisadores descobriram indícios da existência de alguns fenômenos, como o buraco na camada de ozônio, o efeito estufa e o aquecimento global (Armond e Sant'Anna Neto, 2012).

Nesse contexto, a Organização das Nações Unidas (ONU) criou Painel Intergovernamental sobre Mudanças Climáticas (IPCC), em 1988. O IPCC, auxiliado na sua criação pelo Programa das Nações Unidas para o Meio Ambiente (PNUMA) e pela Organização Meteorológica Mundial (OMM), acompanha e realiza estudos sobre a evolução das mudanças climáticas para facilitar que os países criem instrumentos para mitigação dos seus efeitos (Leite, 2015).

Em 1992, a ONU realizou uma grande conferência na cidade do Rio de Janeiro - a ECO-92 - onde as mudanças climáticas novamente estiveram em destaque com a Convenção-Quadro das Nações Unidas para Mudanças Climáticas. Essa convenção formulou a Agenda 21, documento que criou bases para que a sociedade, global e localmente, cooperasse para a solução de problemas socioambientais (Novaes, 2003).

Em 1997, outro documento, o Protocolo de Kyoto, foi ratificado por 55 países, que se comprometeram a reduzir em pelo menos $5 \%$ as suas emissões de gases de efeito estufa entre 2008 e 2012, por meio de ações na área de transportes e no uso de energias renováveis, entre outras (Brasil, 2001). 
A atenção dada aos fenômenos relacionados às mudanças climáticas, levou a mídia a considerar que a frequência e a intensidade dos desastres naturais é uma consequência da mudança climática pela qual a Terra vem passando (Ely, 2009). Essa forma de abordagem, que permanece até os dias de hoje, leva a uma interpretação errônea do grande público sobre os fenômenos, criando uma falsa noção de causalidade entre os desastres e os eventos climáticos que acontecem em seu cotidiano (Steinke, 2004).

O território do DF apresenta, há alguns anos, inúmeros casos de desastres naturais relacionados à ocorrência de precipitações. Os prejuízos que esses desastres causam são mais expressivos entre as populações que moram na periferia. Quando associadas às vulnerabilidades sociais, as vulnerabilidades naturais levam a inúmeras perdas - financeiras, materiais e de vidas - no advento de desastres (Steinke, 2004; Steinke et al., 2006).

As condições atmosféricas impactam diretamente a população e afetam as suas atividades cotidianas. Assim, ocorre midialização dos fenômenos atmosféricos e impactos resultantes deles. A "midialização" é entendida como o processo de divulgação e reprodução de um fato, fenômeno ou processo pelos diversos tipos da mídia (Franzão Neto, 2006).

No Distrito Federal, o processo de midialização dos fenômenos climáticos não é diferente do que acontece em outros contextos, pois a região vem passando por inúmeros desastres naturais, principalmente os de origem meteorológica (Steinke et al., 2006b; Tavares, 2008; Coelho et al., 2013).

\subsection{Justificativa}

A importância desse estudo se dá pelo fato de que durante os anos de 2000 a 2010, o Distrito Federal (DF) apresentou inúmeros desastres naturais cuja intensidade foi amplificada pela abundância de chuvas. O estudo também atende às recomendações de Monteiro (1969) e Zavattini (1996, 2003), que chamam atenção para a carência de estudos de climatologia dinâmica no Centro-Oeste. 


\subsection{Objetivos}

\subsubsection{Objetivo Geral}

Identificar e analisar informações referentes aos seguintes desastres naturais: alagamentos, enxurradas, erosões, movimentos de massa, quedas de granizo e vendavais associados a episódios de precipitação entre 2000 e 2010, publicadas na mídia impressa do DF, com a finalidade de consolidar os dados para identificação dos desastres que mais afetam cada Região Administrativa (RA).

\subsubsection{Objetivos Específicos}

Com relação aos objetivos específicos, são estes:

- Identificar, por meio de análise documental diária no jornal impresso Correio Braziliense, nas edições publicadas entre 2000 e 2010, as ocorrências de desastres relacionadas às chuvas intensas;

- Classificar as ocorrências publicadas nas reportagens de acordo com a classificação do Centro de Estudos e Pesquisas sobre Desastres (CEPED) da Universidade Federal de Santa Catarina (UFSC);

- Confeccionar mapas da distribuição dos desastres associados à chuva no período de estudo.

\subsection{Hipótese}

A hipótese levantada pelo estudo é que a expansão urbana sem 0 devido planejamento e infraestrutura pré-estabelecidos antes da ocupação é o principal condicionante para ocorrência de desastres naturais no DF, e não as precipitações. 


\section{REFERENCIAL TEÓRICO}

\subsection{Desastres Naturais}

Os desastres naturais ocorrem em todas as partes do mundo, determinados a partir da delicada relação entre a sociedade e Natureza, que sempre se deu de maneira violenta quando a humanidade buscou ocupar o meio natural (Kobiyama, 2006).

Grande parte da história humana se deu sob influência de desastres naturais dos mais variados tipos, que aliados à variabilidade climática auxiliam desde votações políticas e aumento de fiéis de religiões até mesmo a ascendência e descendência de diversas culturas (Gasper e Reeves, 2011; Gaillard e Texier, 2010; Zhang et al., 2010).

De acordo com a Organização da Nações Unidas - ONU (2008), entre a década de 1970 até 2000, as perdas econômicas associadas aos desastres naturais cresceram de 12 bilhões para 83 bilhões de dólares. Entre 1974 e 2003, Guha-Sapir, Hargitt e Hoyois (2004) apontam que mais de 2 milhões de pessoas foram mortas por desastres naturais e 182 milhões de pessoas ficaram desabrigadas, afetando cumulativamente mais de 5 bilhões de pessoas.

Para entender melhor os desastres, primeiramente é necessário estabelecer o que são os riscos. Veyret (2007) define risco como a probabilidade de um evento (de origem natural ou não), interagir com vulnerabilidades sociais e the propiciar danos à sociedade, podendo ainda esse risco mudar no tempo e no espaço.

Quanto ao termo desastres, Gonçalves (2003) o define como um evento acima da capacidade de superação ou mitigação dos seus efeitos pela sociedade atingida, cujas consequências alteram ou modificam as funções do território.

Por sua vez, Amaral e Guthjar (2011, p. 20) definem os desastres naturais como: 
(...) A ocorrência de um fenômeno natural que modifica a área terrestre e atinge áreas ou regiões habitadas, causando danos materiais e humanos. A ocupação e intervenção humana em áreas de perigo geológico potencializam a ocorrência de desastres.

É preciso ressaltar que os desastres naturais, apesar das adversidades que provocam à sociedade, também possuem aspectos positivos. Por exemplo, a inundação de um rio pode ser perigosa para as pessoas que vivem em suas margens, porém a mesma inundação fornece ao solo inundado água, sedimento e nutrientes que são fundamentais para o desenvolvimento da biota. Dessa maneira, os fenômenos da Natureza podem oferecer benefícios que podem até ser proveitosos para o ser humano no longo prazo (Silva et al., 2003; Hallegate e Dumas, 2009).

Para realizar o estudo dos desastres naturais, White (1974) e Hewitt (1983) recomendaram a análise de seis itens principais:

- Considerar as áreas de perigo ocupadas pela sociedade;

- Estabelecer uma área de resistência a eventos extremos;

- Sondar a população para saber como ela percebe os desastres;

- Analisar medidas adequadas de resposta aos desastres;

- Presumir como se darão os processos políticos sobre essas medidas;

- Entender como a sociedade contribui para favorecer a ocorrência de desastres.

$\mathrm{Na}$ atualidade, a ocorrência de desastres naturais tem crescido no mundo, sendo o Brasil um dos países mais afetados, como mostram as Figuras 1 e 2. Alguns fatores são preponderantes para ocorrência de desastres, como a geomorfologia, a extensão territorial e número de habitantes (Kobiyama, 2006).

Em relação ao número de pessoas afetadas por desastres, o Brasil é um dos países com mais vítimas, como mostram as Figuras 3 e 4 . 


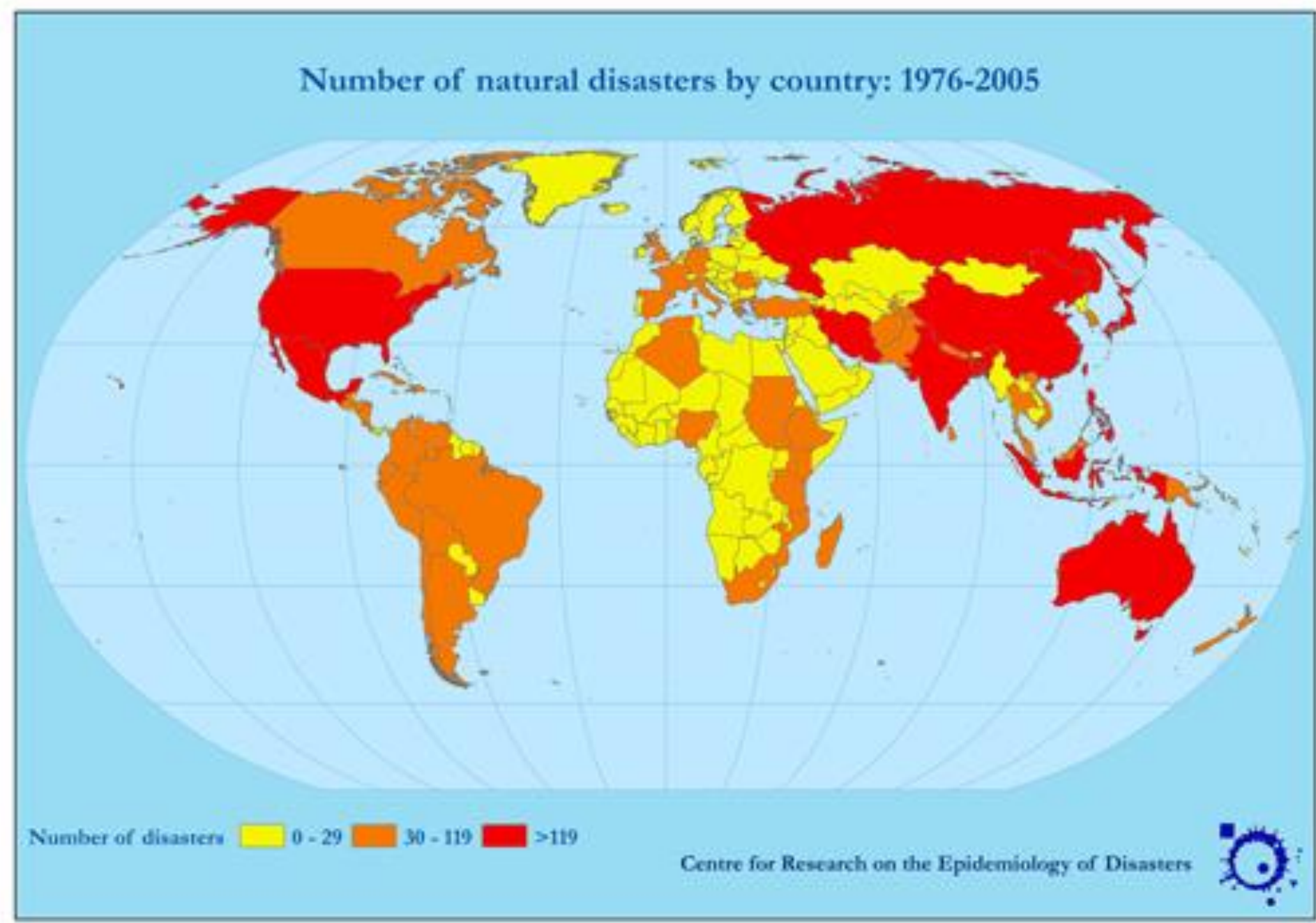

Figura 1. Cartograma do número de desastres naturais por país no período de 1976 a 2005. Fonte: Reprodução / EM-DAT (2015). 


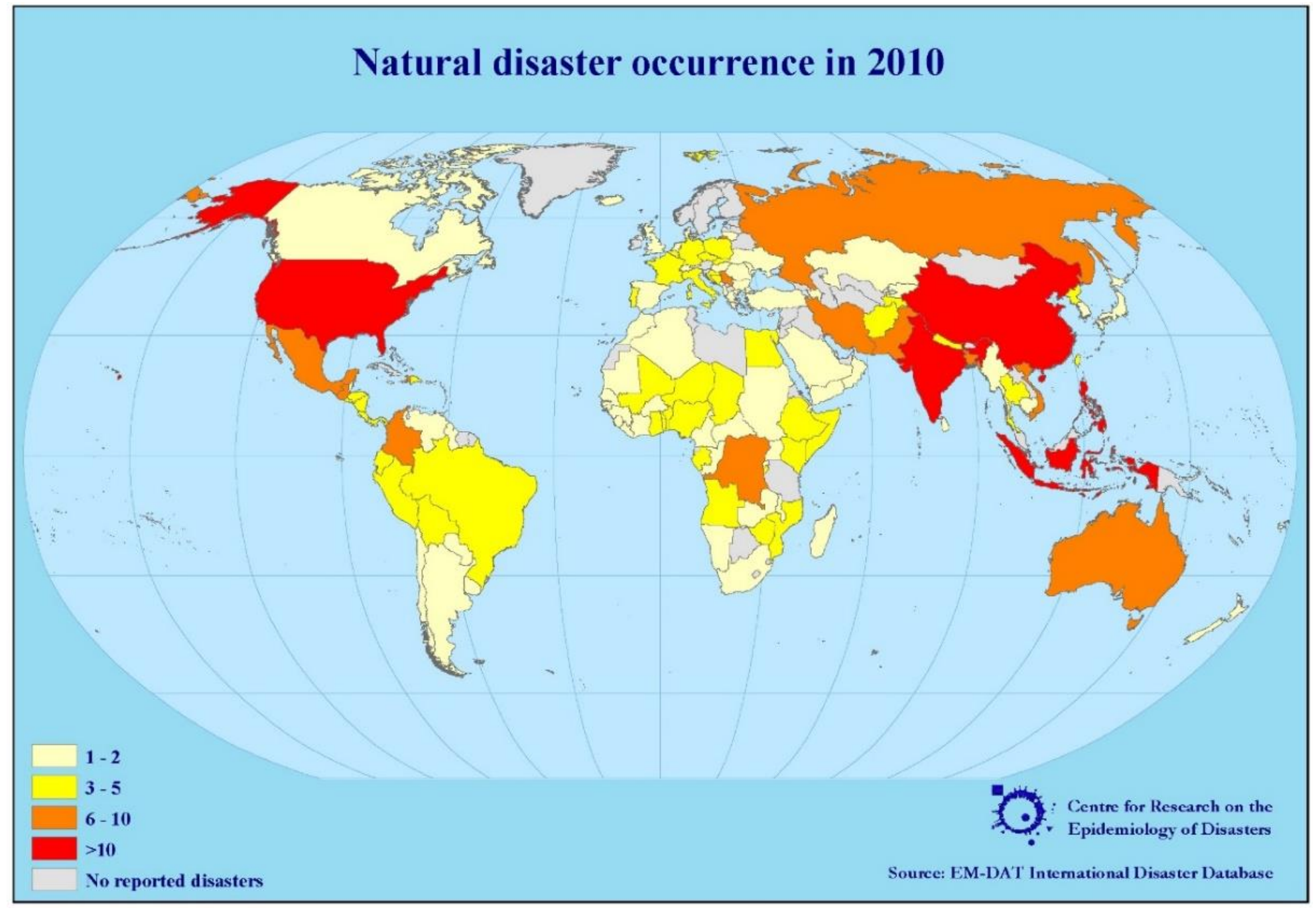

Figura 2. Cartograma da ocorrência de desastres naturais em 2010 por país. Fonte: Reprodução / EM-DAT (2015). 


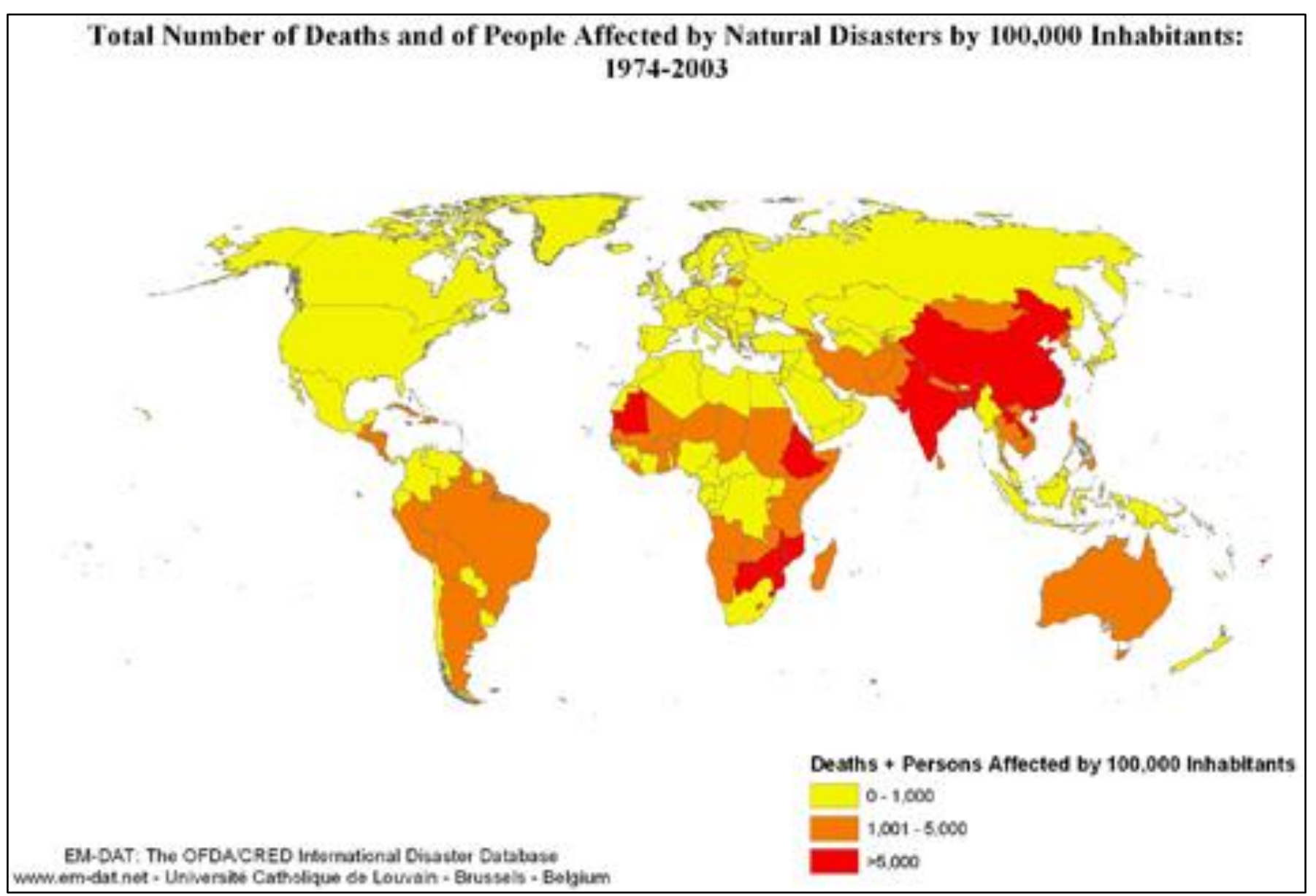

Figura 3. Cartograma do número mortes e pessoas afetadas por desastres naturais por país no período de 1976 a 2005.

Fonte: Reprodução / EM-DAT (2015). 


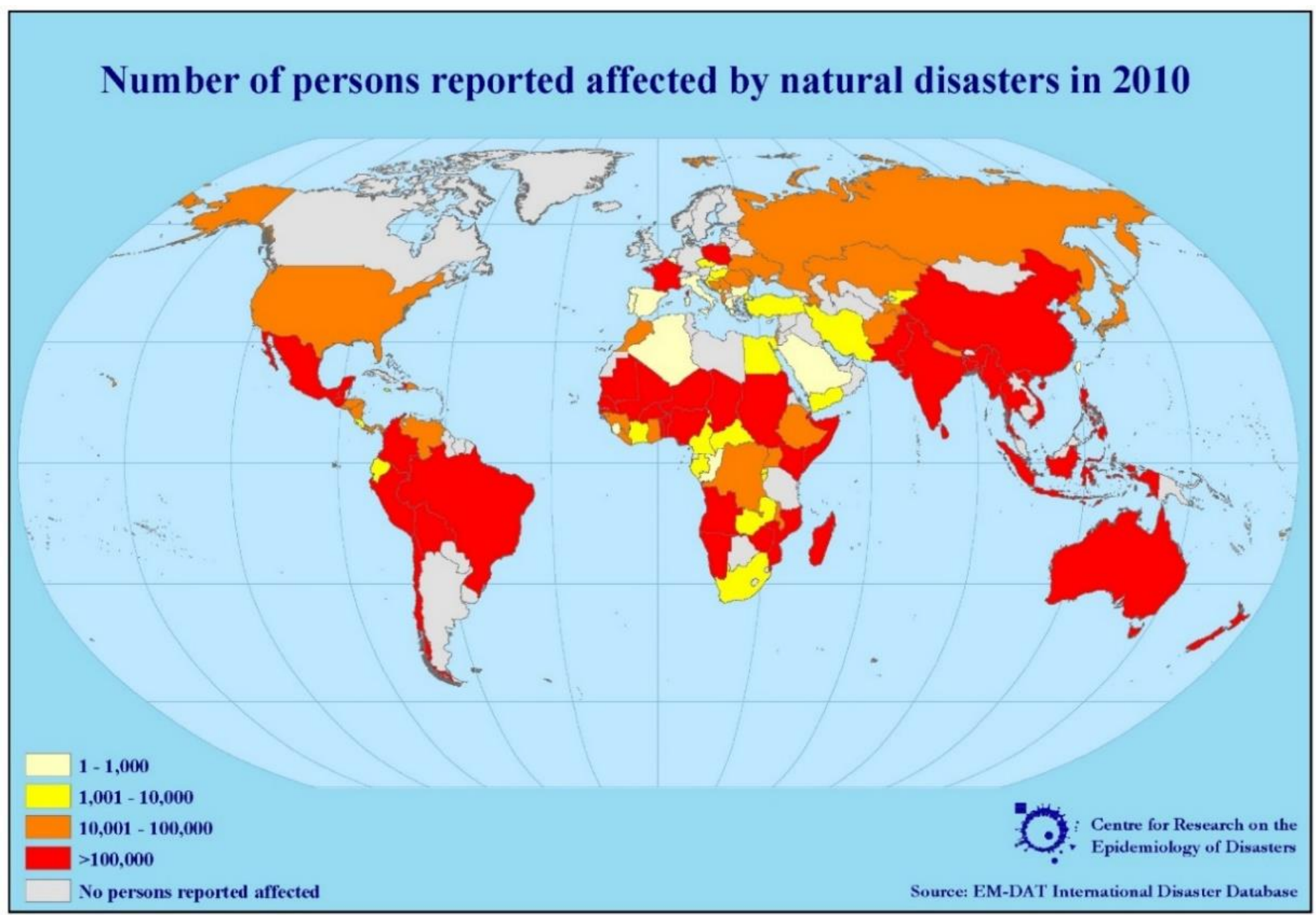

Figura 4. Cartograma do número de pessoas afetadas por desastres naturais em 2010 por país. Fonte: Reprodução / EM-DAT (2015). 
Em relação a todos os tipos de desastres, de acordo com os dados do EM-DAT (2015), até 2004 os desastres naturais teriam causado mais de 10 mil mortes no mundo. No tempo histórico, a ocorrência de desastres é pouco estudada, porém segundo Kobyiama (2006, p. 13) há dois aspectos que se reproduzem temporalmente:

Um é a repetitividade, isto é, os desastres podem ocorrer diversas vezes em um mesmo lugar. Por exemplo, se não houver alteração na condição climática e na condição geomorfológica, a inundação e o escorregamento podem ocorrer várias vezes no mesmo local. O outro aspecto é que um determinado tipo de desastre pode alterar-se ao longo do tempo em um mesmo local. Devido as intervenções humanas, as condições geoambientais normalmente se alteram, por exemplo, através das formas de uso do solo. Isto pode facilitar ou diminuir a possibilidade de ocorrência de um tipo de desastre e até provocar o surgimento de outro tipo.

As melhorias tecnológicas são responsáveis pela redução na ocorrência ou consequências de alguns tipos de desastres, como estiagens e epidemias. Como exemplo, temos os EUA e a Austrália, que apesar de sofrerem com uma quantidade considerável de movimentos de massa (Figura 5) e alagamentos e inundações (Figura 6), não tem tantas pessoas afetadas por desastres como os países emergentes. 


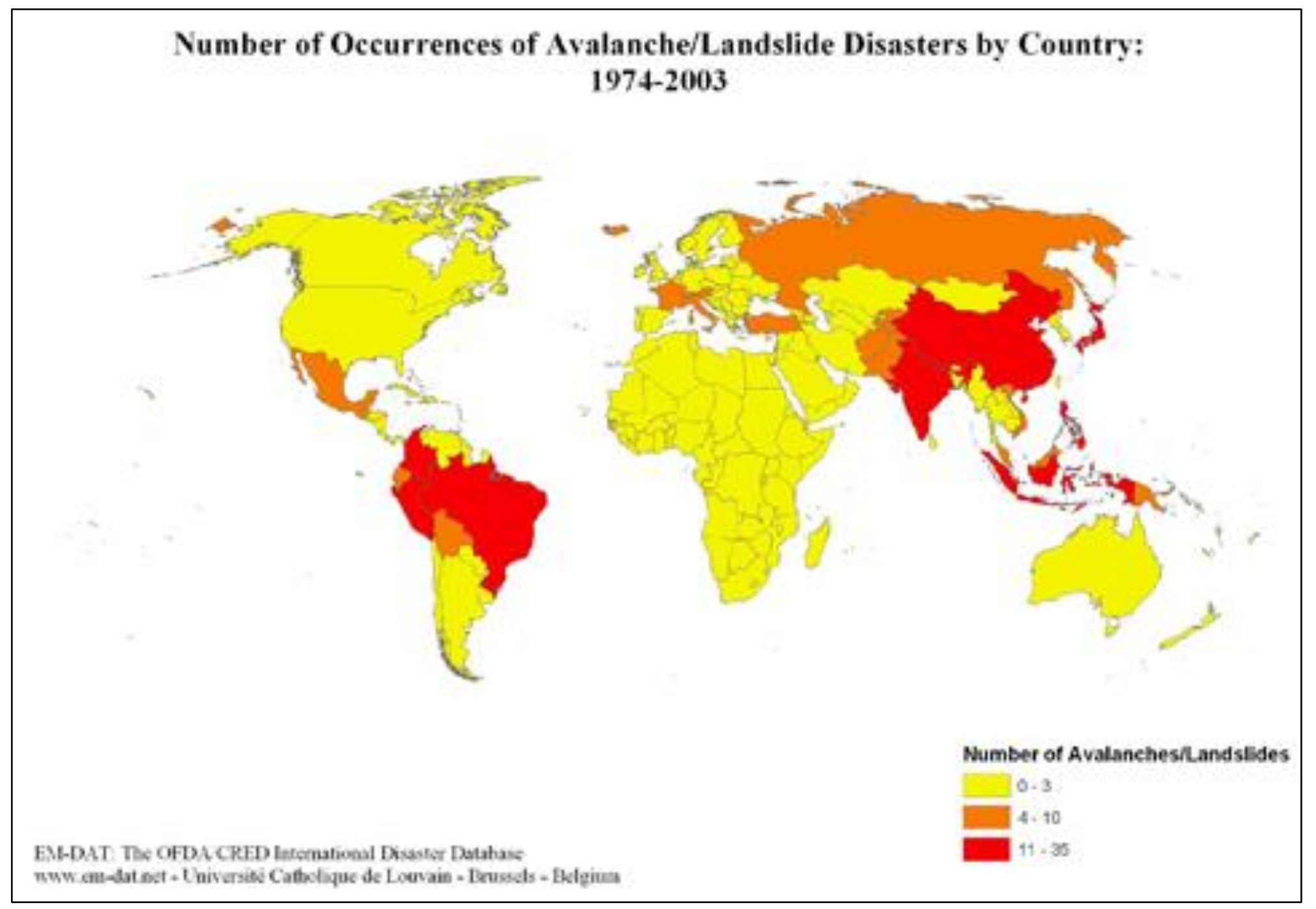

Figura 5. Número de ocorrências de alagamentos por país no período de 1974 a 2003. Fonte: Reprodução / EM-DAT (2015). 


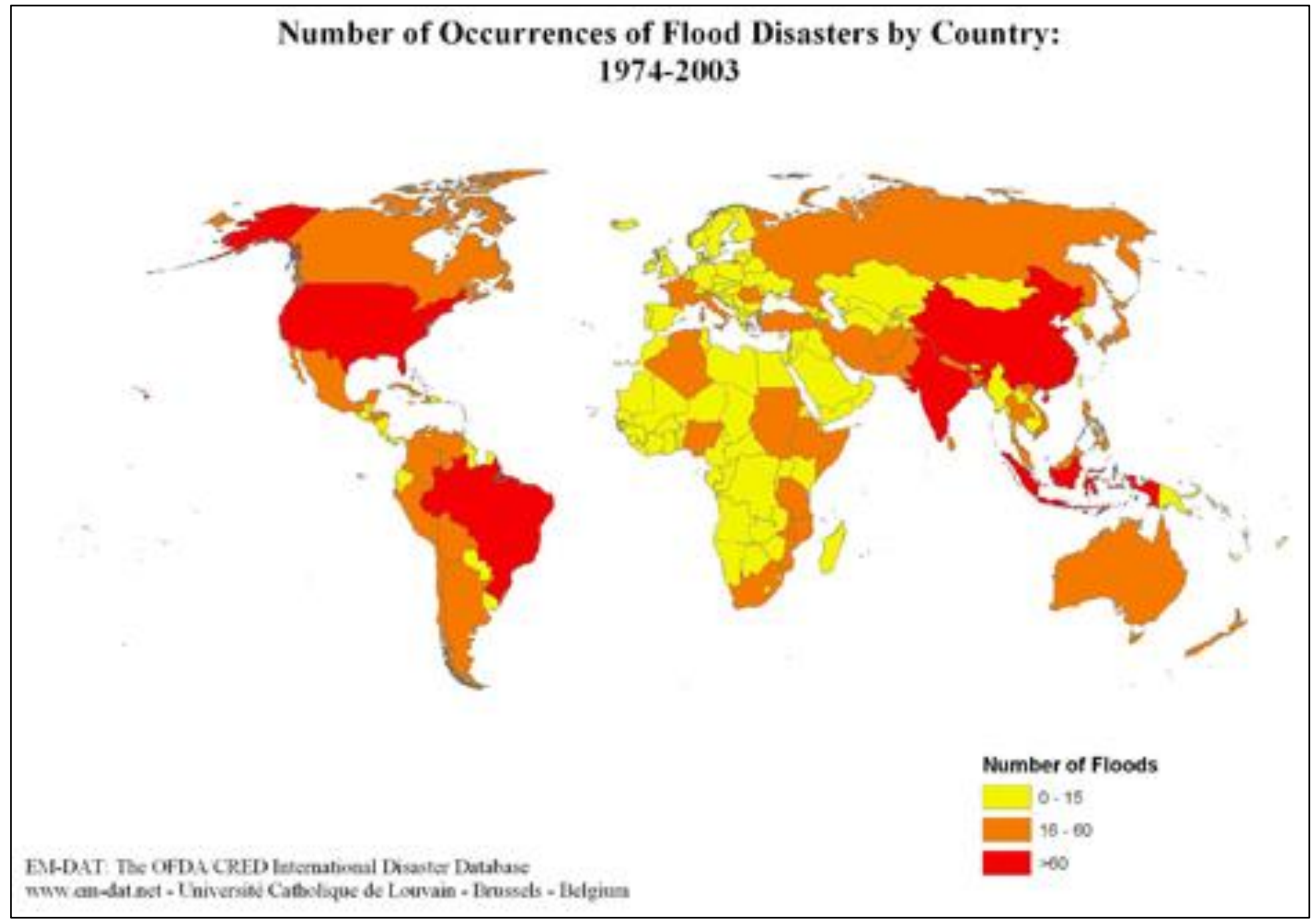

Figura 6. Número de ocorrências de alagamentos por país no período de 1974 a 2003. Fonte: Reprodução / EM-DAT (2015). 
Amaral e Guthjar (2011, p. 24) destacam que:

No Brasil, as condições climáticas fazem com que a Região Centro Oeste seja uma das mais afetadas por incêndios florestais. $\mathrm{Na}$ Região Nordeste, o desastre natural que mais atinge a população é a seca. A Região Sul é a área mais sujeita a vendavais e granizos, por ser a mais afetada pelas frentes frias.

Segundo o CENAD (2013), entre 1990 e 2012 ocorreram mais de 38 mil registros de ocorrência de desastres naturais no Brasil. Desses, mais de 8.515 ocorreram na década de 1990, 21.741 ocorreram na década de 2000 e entre 2010 e 2012, ocorreram 8.740 desastres.

Os Gráficos 1, 2, 3 e 4 mostram como de 2001 a 2012 essa evolução na ocorrência de desastres se deu de maneira mais acelerada que na década de 1990. Esse processo é resultado: (i) da melhoria de técnicas na coleta de dados sobre desastres e do aparelhamento da Defesa Civil, (ii) do aumento populacional e ocupação de áreas de risco (iii) do aumento da intensidade dos desastres naturais, influenciados por fenômenos naturais como o El Niño e La Niña.

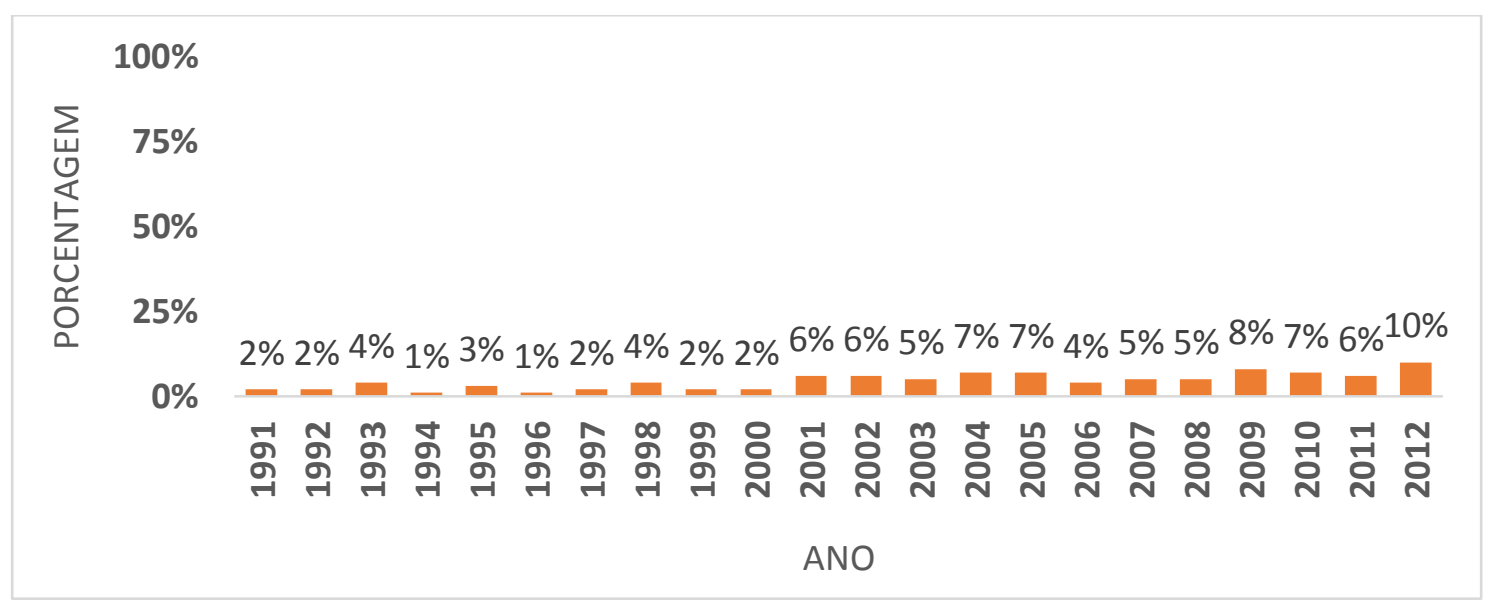

Gráfico 1. Porcentagem de Desastres naturais no Brasil no período entre 1991 e 2012.

Fonte: CENAD (2013). 


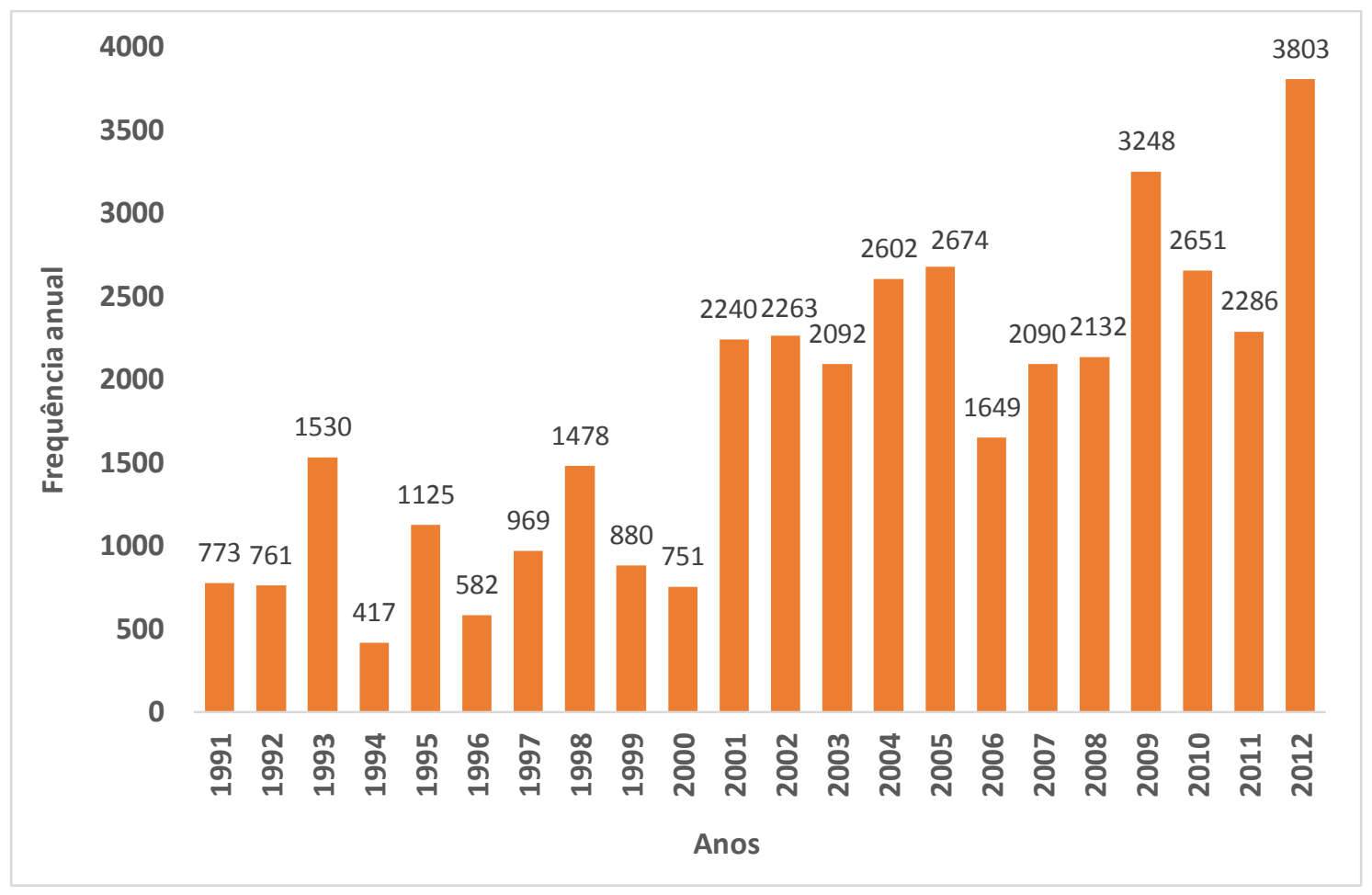

Gráfico 2. Frequência anual de desastres naturais ocorridos no Brasil entre 1991 e 2012.

Fonte: CENAD (2013).

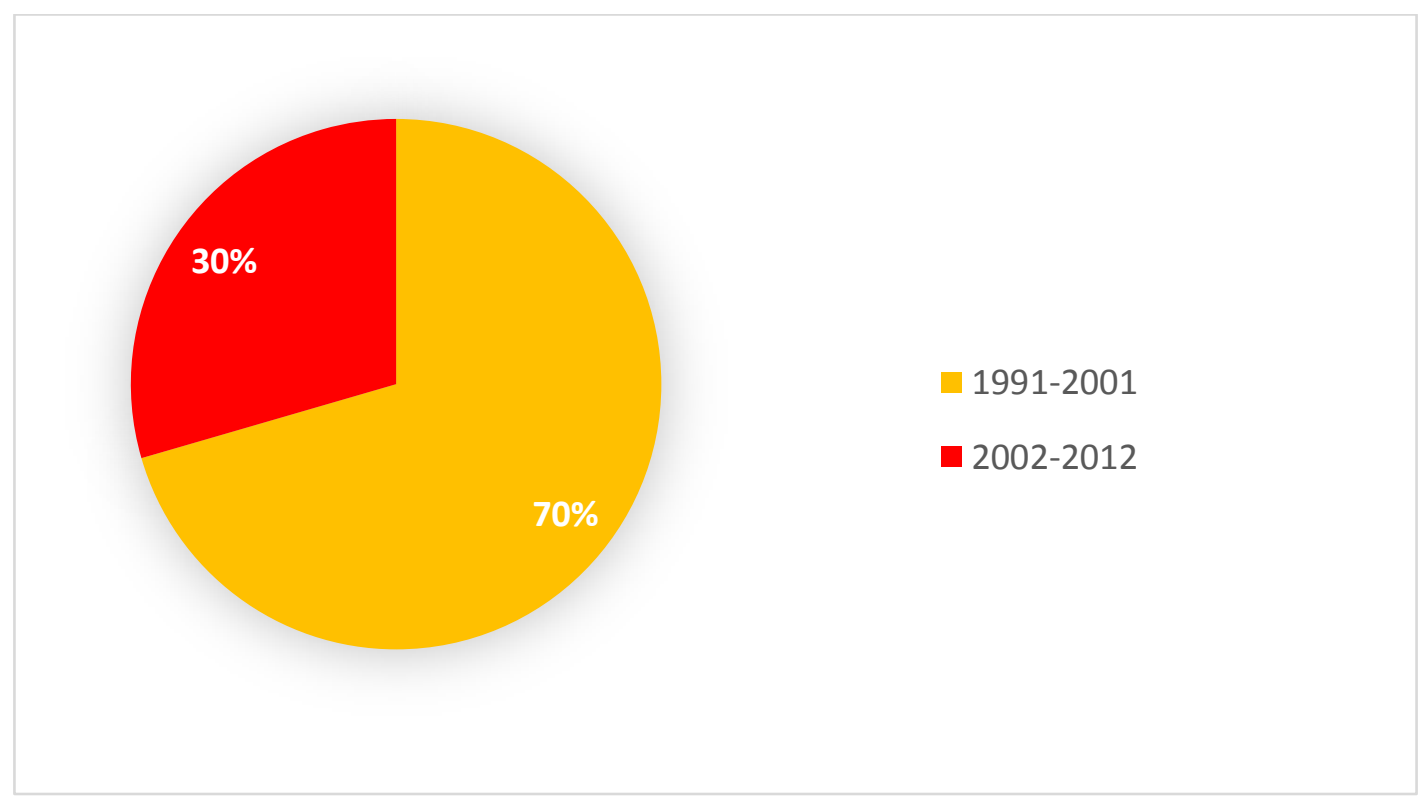

Gráfico 3. Comparação entre os desastres naturais ocorridos no período 1991-2011 e no período 2002-2012.

Fonte: CENAD (2013). 


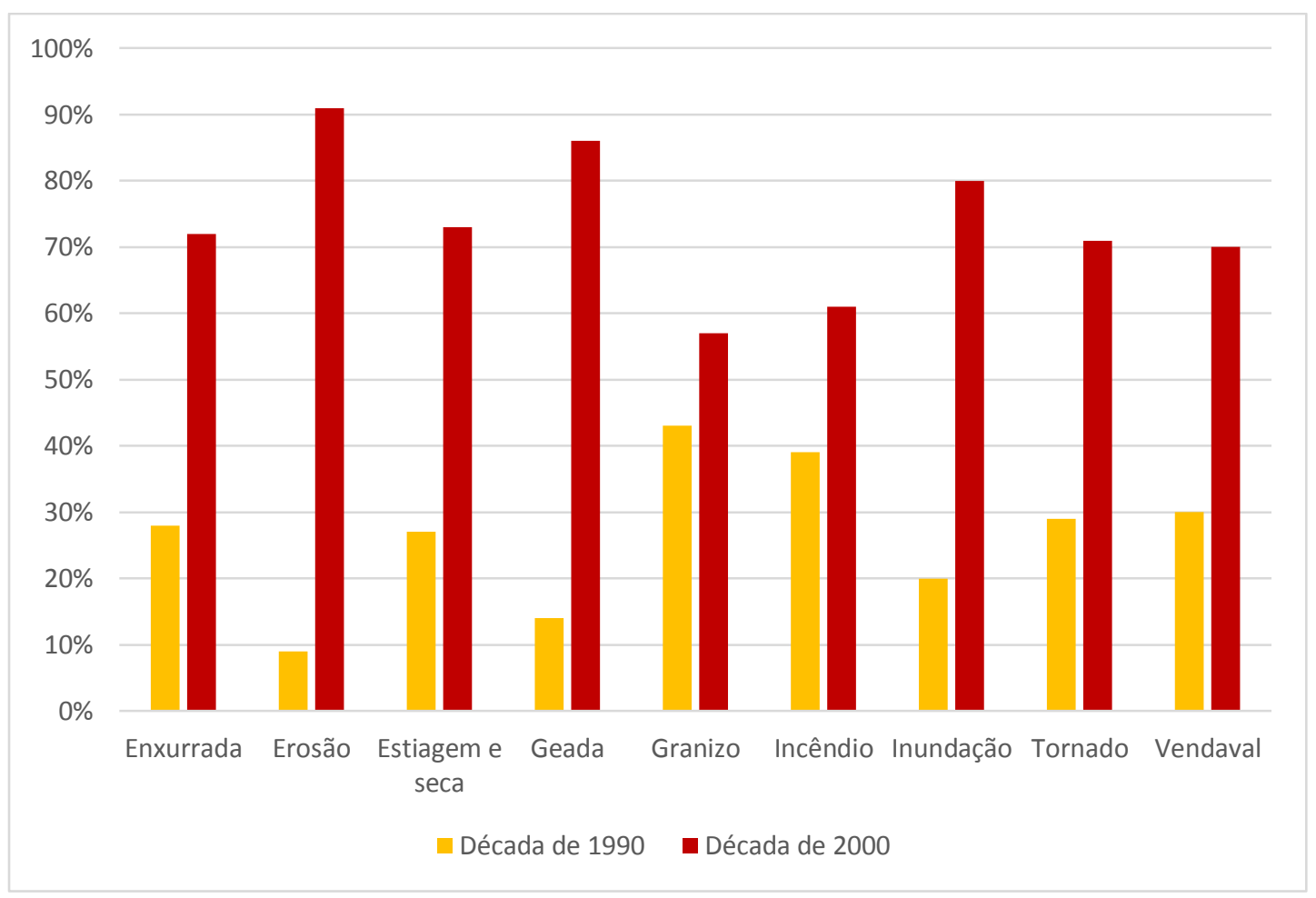

Gráfico 4. Evolução histórica dos desastres naturais ocorridos no Brasil entre 1991 e 2012.

Fonte: CENAD (2013).

Nos Gráficos 5 e 6, observa-se que a estiagem ainda é o principal desastre natural que ocorre no país, apesar de os meios tecnológicos e obras como a transposição do rio São Francisco amenizarem os seus efeitos sobre a população no Nordeste. As enxurradas e erosão são respectivamente o segundo e terceiro desastres naturais com maior número de ocorrência registradas, devido ao maior número de chuvas que aconteceu entre 2001 e 2012. 


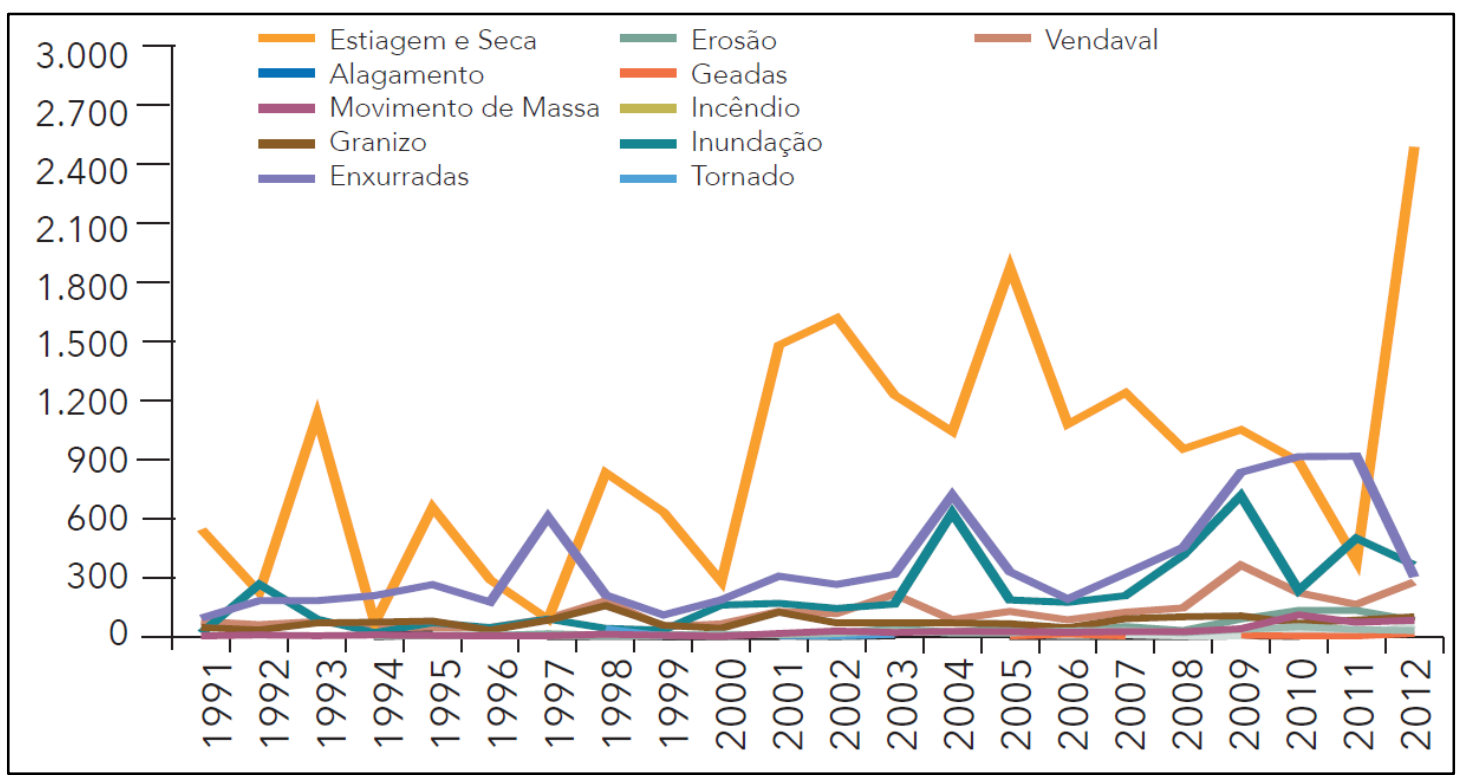

Gráfico 5. Comparativo de ocorrência de tipo de desastres ocorridos por ano no período 19912012.

Fonte: Reprodução / CENAD (2013).

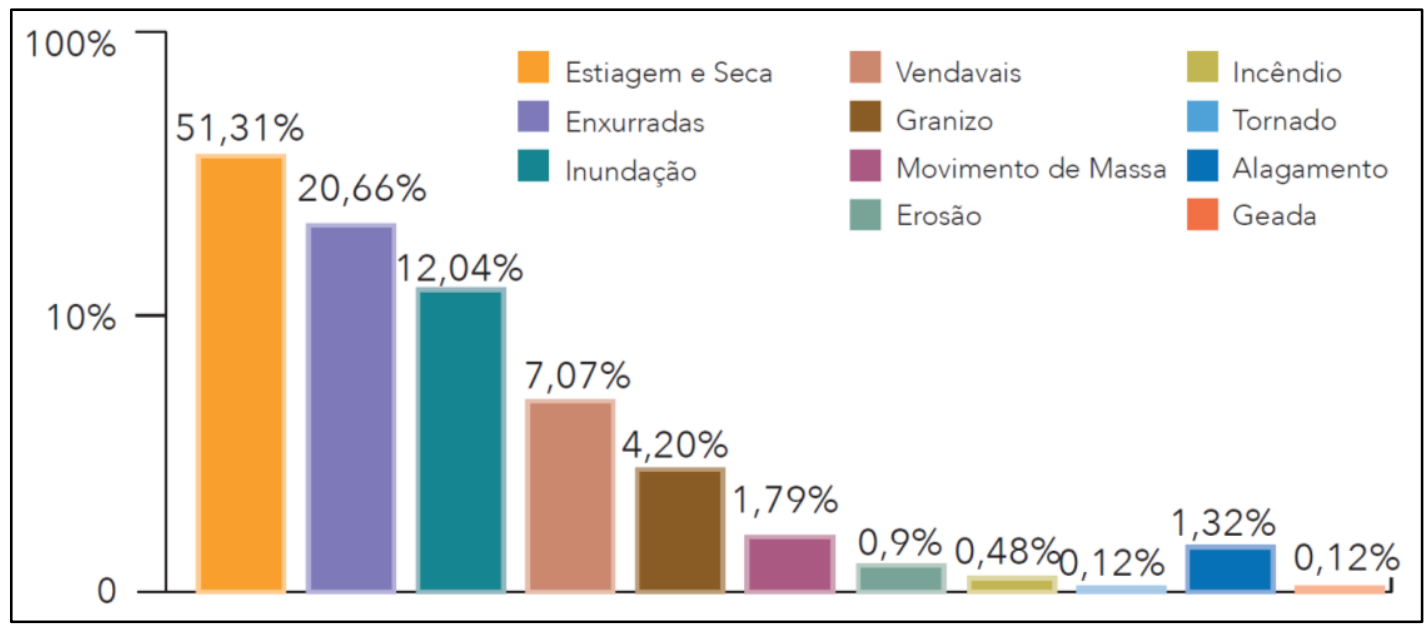

Gráfico 6. Porcentagem de pessoas afetadas por desastres naturais por tipo de desastre.

Fonte: Reprodução / CENAD (2013).

Ressalta-se o fato de que as chuvas não são as principais catalisadoras de desastres, mas favorecem a ocorrência desses. $O$ aumento da população, o crescimento desordenado das cidades e a ocupação de áreas de risco, entre outros fatores, ainda são os maiores responsáveis pela ocorrência dos desastres no país (Brasil, 2012). 


\subsection{Clima e mídia impressa}

Com a difusão das novas tecnologias de informação, a mídia está cada vez mais presente no cotidiano das pessoas, atingindo todas as parcelas da população. No entanto, cada cidadão possui graus diferenciados de curiosidade e envolvimento, que varia de acordo com os temas que são debatidos na mídia (Steinke, 2006a).

A imprensa atua diretamente na formação de opinião da população. A importância que ela tem para compreensão dos fatos e fenômenos científicos e na reprodução destes para a sociedade é fundamental para inserção dos fenômenos climáticos na formação e nas discussões do senso comum (Gunther et al., 2001; Choi, Yang e Chang, 2009; Daddow, 2012).

Mesmo quando a informação veiculada é a mesma, sua apreensão é distinta, tanto pelo reprodutor da informação quanto pelo público. O mesmo acontece com a temática das mudanças climáticas, onde se observa grande parte dos veículos de comunicação se baseiam no sensacionalismo para ganhar público (Steinke, 2004; Nisbett, 2009; Höijer, 2010; Smith e Joffe, 2013).

Dessa maneira, o jornal impresso pode ser utilizado como fonte primária de informações para a análise científica, desde que receba o tratamento adequado. Cabe ressaltar que é por meio da mídia que o cidadão comum tem acesso ao conhecimento científico (Cooper, 2011).

\subsubsection{Clima e mídia impressa no mundo}

Hoje, cada vez mais a mídia influencia na formação da opinião da população a respeito dos temas concernentes ao tempo e clima, sobremaneira naqueles que envolvem as mudanças climáticas. Isto tem chamado a atenção de pesquisadores ao redor do mundo. Prova disso é o aumento do número de publicações que envolvem o estudo da mídia impressa e o clima em periódicos de alto fator de impacto, como mostra o Gráfico 7. 


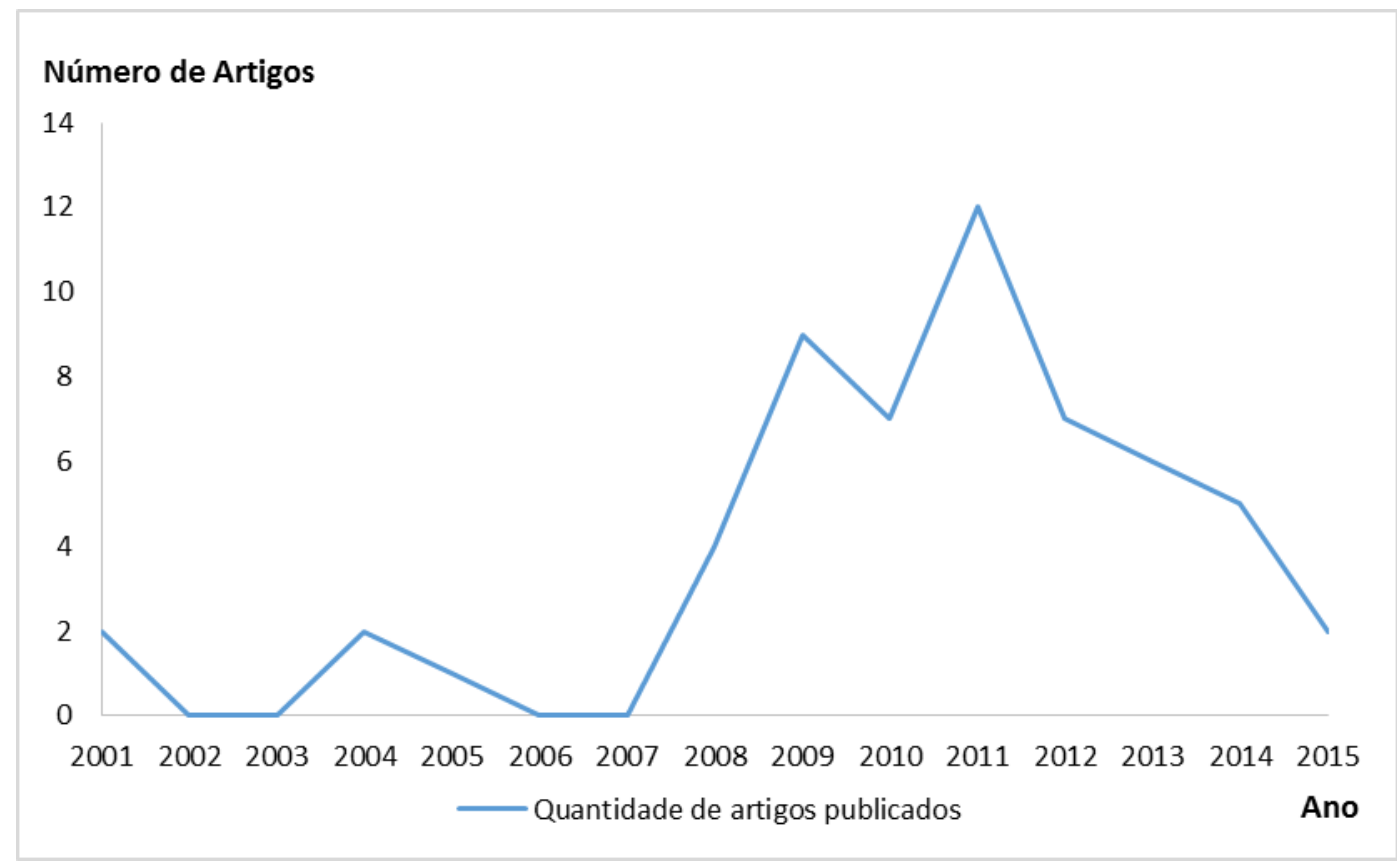

Gráfico 7. Número de artigos publicados com as palavras-chave climate (clima) e press media (mídia impressa) em periódicos com fator de impacto > 1 na plataforma Web of Science.

Fonte: Reuters (2015).

No Canadá, Ahchong e Dodds (2007) utilizaram os jornais Toronto Star e The Globe and Mail como base da sua pesquisa. Sua pesquisa estudou as notícias referentes ao período de 1998 a 2007. Eles mostraram que o número de notícias sobre aquecimento global e as mudanças climáticas aumentou consideravelmente no período estudado. Para os autores, as estratégias de mitigação dos efeitos das mudanças climáticas deveriam dar espaço a estratégias de adaptação a elas.

DiFrancesco e Young (2011) analisaram os jornais The Globe and Mail e The National Post. A partir de uma abordagem antropológica, os autores constataram que a linguagem visual e linguística das notícias as colocavam em direções opostas. Por vezes, as reportagens mostravam imagens que contradiziam o que estava no texto e vice-versa. Os autores apontam em como isso confunde e ajuda a dividir a opinião pública com relação aos efeitos das mudanças climáticas.

Os Estados Unidos da América (EUA) destacam-se por ser, junto com o Reino Unido um dos berços da discussão a respeito de mídia e clima. O país 
tem um forte lobby tanto a favor quanto contra as mudanças climáticas e o aquecimento global e é um dos principais - se não o principal - países emissores de gases estufa. Isso faz dos EUA um campo fértil nesse campo de pesquisa (Antilla, 2010).

Antilla (2005) utilizou softwares de pesquisa para pesquisa de palavras em jornais. A autora analisou 32 palavras-chave em 255 jornais norteamericanos de março de 2003 a fevereiro de 2004. O estudo constatou que a maioria das notícias são construídas retoricamente, com base na incerteza, controvérsia e ceticismo sobre existência ou não das mudanças climáticas e de seus efeitos sobre a sociedade.

O trabalho de Liu et al. (2008) pesquisou 795 reportagens para expor a caracterização do aquecimento global e das mudanças climáticas no jornal regional texano The Houston Chronicle, de 1992 a 2005. Para tanto, dividiram a análise dos dados em vários atributos para identificar a apropriação das informações científicas pela mídia. Os autores observaram que a atenção gerada pelas notícias aumentava consideravelmente na medida em que estas noticiavam os efeitos das mudanças climáticas como catástrofes.

M. Boykoff e J. Boykoff $(2004,2007)$ analisaram os jornais The New York Times, The Washington Post, The Los Angeles Times e The Wall Street Journal, considerados os quatro maiores dos EUA, no período entre 1998 e 2002. Para os autores, as notícias desses jornais contribuíram para criação de um ambiente de grande divergência entre o discurso popular e o discurso científico. Isto impactou a formulação de políticas públicas e a campanha de eleição presidencial americana.

No Peru, Takahashi e Meisner (2012) realizaram uma das poucas pesquisas com foco em países em desenvolvimento, mostrando a força que as vozes estrangeiras possuem sobre países nessa situação. $O$ estudo analisou notícias publicadas nos jornais Correo, El Comercio, El Peruano (jornal oficial do governo peruano), Expreso, La Primera, La Razon, La Republica, Gestion, Ojo, e Peru21, de 2000 a 2010. Os resultados mostraram novamente que a cobertura jornalística prioriza ações de mitigação ao invés de ações de 
adaptação às mudanças climáticas. Os autores apontam que estas medidas ainda são insuficientes para um país como o Peru, que possui muitas vulnerabilidades ambientais.

$\mathrm{Na}$ Índia, o trabalho de Billett (2010) traz contribuições especiais ao analisar os jornais (publicados em inglês) The Times of India, The Hindu, Hindustan Times e The Indian Express por meio de palavras-chave e entrevistas com seus escritos. A questão das mudanças climáticas é debatida com base numa pergunta chave: os países emergentes devem desenvolver-se aumentando a emissão de gases estufa ou diminuir as emissões e 0 crescimento econômico subjacente? $\mathrm{O}$ autor chama atenção para o que chama de "divisão de responsabilidade dos riscos" (risk-responsability divide, em inglês) que é realizada desigualmente. Ele constata que os países ricos são os maiores responsáveis pelas emissões de gases estufa e querem manter seu alto nível de emissões reduzindo as emissões dos países em desenvolvimento.

O trabalho de Sampei e Aoyagi-Usui (2009) analisou os três jornais de maior circulação no Japão: Yomiuri Shimbun, Asahi Shimbun e Mainichi Shimbun, de janeiro de 1998 a julho de 2007. Os resultados mostraram que conforme avançaram os anos, a cobertura das notícias sobre o aquecimento global teve uma resposta mais rápida da opinião pública. Isto gerou uma forte campanha nacional em prol da redução de gases estufa. Conforme a campanha avançou, a quantidade de notícias sobre aquecimento global aumentou consideravelmente.

Na Finlândia, Lyytimäki (2011) analisou os jornais Helsingin Sanomat, Keskisuomalainen, Aamulehti, Ilta-Sanomat, Iltalehti e Maaseudun Tulevaisuus por meio de um software de pesquisa, utilizando a palavra-chave "mudança climática", de 1990 a 2010. Os resultados mostraram a importância de acompanhar a cobertura midiática como um fator preponderante para a formulação e implementação de políticas ambientais.

Pasquaré e Oppizzi (2012) realizaram a análise dos dois maiores jornais italianos, o La Repubblica e o Corriere della Sierra, de 2007 a 2008, por meio de software de pesquisa de palavras-chave. Os resultados apresentados 
expuseram que o foco midiático das mudanças climáticas se dá no país mais pelos danos socioambientais que elas podem causar do que na prevenção dos seus efeitos.

A Noruega traz o estudo de Eide e Ytterstad (2011), baseado nos jornais Verdens Gang e Aftenposten. Os autores mostraram que as discussões sobre mudanças climáticas cresceram substancialmente no país após a Conferência Climática de Bali em 2007. Eles também ressaltam a importância de os jornalistas manterem o bom senso na publicação das notícias para que se evite 0 alarde e o sensacionalismo.

O Reino Unido é o país que apresenta a maior quantidade de trabalhos científicos encontrados sobre clima e mídia impressa, pois serve base institucional para a maioria dos pesquisadores da temática e apresenta um grande número de jornais e tabloides (Russill e Nyssa, 2009).

As pesquisas de Boykoff (2008) e Boykoff e Mansfield (2008), analisaram os jornais The Sun, Daily Mail, Daily Express e The Mirror, examinando notícias publicadas de 2000 a 2006. Por meio de palavras-chave somadas a entrevista de jornalistas e editores, eles buscaram identificar o foco das coberturas jornalísticas e a repercussão delas sobre a população. Os resultados mostraram que as reportagens focam mais em eventos climáticos e movimentos ambientais e políticos do que na análise de vulnerabilidades e riscos das mudanças climáticas.

Doulton e Brown (2009) investigaram a construção discursos midiáticos sobre as mudanças climáticas. Seus resultados permitiram os autores observarem que os discursos se dividem em oito grupos: (i) otimismo, (ii) racionalismo, (iii) mitigação ética, (iv) autojustiça, (v) ocorrência de desastres, (vi) catástrofes potenciais, (vii) crises e (viii) oportunidades. Essa pesquisa foi continuada em outro estudo (Brown et al., 2011), que analisou cerca de 1300 jornais ingleses de abrangência local e regional no período que vai de 1997 a 2007 com base em softwares de busca de palavras-chave. Os estudos chamam atenção para o fato de que a mídia tem mudado a escala dos efeitos dos fenômenos relacionados às mudanças climáticas da escala global para a 
escala local. De acordo com os estudos, isto gera distorções drásticas na apreensão da população local sobre o aquecimento global e as mudanças climáticas.

O trabalho de Cherry et al. (2015) se debruçou na análise dos jornais The Guardian, The Independent, The Telegraph e The Times de 2006 a 2011, com foco nas emissões de carbono. A pesquisa mostrou que as reportagens desses jornais marginalizam os aspectos sociais em prol dos aspectos tecnológicos e econômicos.

O trabalho de Gavin et al. (2011) verificou nos jornais e tabloides britânicos The Guardian, The Times, The Independent, The Telegraph, The Mail, The Express, The Mirror, The Sun, as conexões que estes faziam entre as mudanças climáticas e as inundações no Reino Unido de janeiro de 2001 a julho de 2007. Para tanto utilizaram um sistema base de dados nacional da cobertura de mídia impressa (Lexis Nexis). Os resultados apontaram que mesmo que o debate entre os jornalistas e os cientistas se dê de forma tênue, ele colabora para melhoria das políticas públicas sobre o tema.

As pesquisas de Jaspal e Nerlich (2012) e Jaspal, Nerlich e Koteyko (2012) trazem à tona a análise dos comentários de leitores do jornal Daily Mail sobre notícias referentes às mudanças climáticas, baseados numa análise sociológica. Os resultados mostraram que as construções sociais feitas pelos leitores com relação à temática das mudanças climáticas são controversas porque próprias as reportagens publicadas pelo jornal difundem ideias contraditórias muitas vezes.

Na Rússia, Poberezhskaya (2014) analisou a cobertura de três eventos (Conferências Climáticas de Kyoto e Copenhagen e a onda de calor na Rússia em 2010) em cinco jornais russos: Komsomol'skaya Pravda, Rossiyskaya Gazeta, Izvestiya, Kommersant e Sovetskaya Rossiya. O artigo mostrou que os grandes veículos da mídia impressa na Rússia maquiam as práticas pouco eficazes da política desse país para criar medidas de mitigação às mudanças climáticas. 
$\mathrm{Na}$ Oceania, Kenix (2004) realiza uma análise comparativa entre o jornal independente Scoop e o jornal de grande circulação The New Zealand Herald nos anos de 2006 e 2007. Os resultados mostraram como são diferentes as abordagens do mesmo assunto pelos jornais e em como o jornal mais popular tem um compromisso com a propaganda catastrófica das mudanças climáticas.

Schmidt et al. (2013) realizaram uma ampla revisão bibliográfica da abordagem da relação entre clima e mídia impressa em 27 países de 1996 a 2010. Os resultados apontaram que a mídia dos países ocidentais se preocupa mais com a questão das mudanças climáticas do que os países do oriente. De acordo com os autores, há ainda uma grande discordância entre os países do oriente e do ocidente sobre os efeitos econômicos de se adotar medidas para prevenção e mitigação das consequências das mudanças climáticas.

Dando prosseguimento à pesquisa anterior, Schäfer et al. (2014) pesquisas quais eram palavras-chave que chamavam mais atenção da mídia nos dois jornais mais vendidos da Alemanha, Austrália e Índia de 1996 a 2010. Para tanto, eles usaram uma série de análises matemáticas para verificar a influência das características meteorológicas em vários períodos distintos e medir a atenção social dada a esses eventos. Como resultado, os autores puderam constatar que que os fenômenos meteorológicos e suas consequências funcionam como importantes chamamentos de leitores para reportagens nesses três países.

Zamith et al. (2013) analisaram o tratamento das mudanças climáticas em jornais de quatro países: Argentina (La Nación), Brasil (Folha de São Paulo), Colômbia (El Tiempo) e Estados Unidos (The New York Times). A pesquisa expôs a fragilidade das discussões, focadas sempre nas catástrofes, e a falta de foco das coberturas sobre as mudanças na Argentina e na Colômbia. No Brasil e nos Estados Unidos os jornais focavam as políticas de mitigação dos efeitos das mudanças climáticas.

No trabalho de Ford e King (2015) a abordagem da adaptação às mudanças climáticas pela mídia é o foco. Para realizar a análise os autores utilizaram o software de busca de palavras-chave Pro-Quest para verificar a 
questão nos jornais Globe \& Mail e Toronto Star (Canadá) e The New York Times e The Washington Post (EUA). O estudo constatou que a maioria das notícias e reportagens publicadas trata apenas das necessidades de adaptação do homem às mudanças climáticas, não mostrando as medidas efetivas que já estão sendo tomadas para incentivar e preparar a população para as mudanças.

\subsubsection{Clima e mídia impressa no Brasil}

Ao se falar em desastres de gênese climática, a maioria das pessoas remete seu pensamento aos fenômenos de grandes proporções, como os furacões e os tornados, pois o senso comum associa esses fenômenos com a ocorrência de morte e destruição. Porém, as tempestades tropicais, como as que ocorrem na região Centro-Oeste e no Distrito Federal também geram impactos negativos e, dependendo da área atingida, até mortes. Sendo assim, é possível afirmar que a população do Distrito Federal também sofre com desastres de origem climática e, a cada ano que passa, as ocorrências tendem a aumentar em função da ocupação em áreas de risco (Steinke, 2004).

No Brasil, há uma opinião sendo formada pelo grande público de que as precipitações, agravadas por fenômenos associados a mudanças climáticas, são as principais responsáveis pelos desastres naturais que vêm ocorrendo frequentemente nos últimos anos (CEPED, 2013; BRASIL, 2012, 2013, 2014).

Todavia, a população tem crescido de forma vertiginosa desde a década de 70, e esse crescimento, aliado à modernização agrária ocorrida, resultou em um grande inchaço das cidades (Silva, 1982), que por sua vez impulsionou um grande processo de ocupação de áreas vulneráveis (Zanella, 2006).

As práticas de estudo da mídia pela Geografia e outras ciências ainda são incipientes, tanto no Brasil quanto em outros países emergentes e pobres (sobretudo na África). Isso ocorre por vários motivos: os meios de comunicação estão concentrados nas mãos de grandes empresas; há dificuldade no acesso às publicações, principalmente as publicadas antes de 2000; as publicações não estão digitalizadas por meio de softwares e disponibilizadas em ferramentas de pesquisa; etc. (Schmidt et al., 2013). Nesse contexto, a 
imprensa é um dos principais meios de informação dos fenômenos climáticos que ocorrem no espaço geográfico (Armond e Sant'Anna Neto, 2012).

A imprensa atua diretamente na formação de opinião da população. Ela possui grande importância para compreensão dos fenômenos meteorológicos e climáticos pela sociedade. Steinke (p. 7, 2004) aponta como isso ocorre:

\begin{abstract}
O nível de cobertura da imprensa em relação aos aspectos climáticos e suas relações também deve ser considerado, uma vez que é por meio da mídia que o público em geral recebe informações a respeito de tais como, as mudanças climáticas. É papel do jornalista alertar a sociedade para a gravidade da situação, se ela ocorrer, sem cometer o pecado do sensacionalismo e sem explorar de modo irresponsável as previsões catastróficas dos cientistas.
\end{abstract}

Com relação à mídia impressa, Zanella (2006, p. 202) destaca o quão relevante é a análise do jornal impresso:

Ver a cidade através da linguagem escrita sobre ela, utilizando o aporte do jornal, talvez seja uma das formas mais cruéis de enxergar a realidade de uma cidade. No entanto é, também, uma maneira complexa de se poder ver e entender as relações de vivência que quem a escreve possui com ela, e de como ela reflete o pensar do morador, principalmente daquele que vivencia as inundações, temática aqui abordada.

Devido a recorrência dos desastres naturais relacionados às chuvas no Brasil, diversos estudos já foram publicados sobre a relação entre a mídia impressa e desastres.

O trabalho de Cambra e Coelho Netto (1997) abordou as chuvas no Rio de Janeiro no mês de março de 1993. Os autores utilizaram dados meteorológicos e notícias dos jornais impressos Jornal do Brasil e O Globo. Os resultados mostraram que a ocupação dos morros e encostas pelas favelas em alguns bairros da cidade, em curso desde a década de 40, resultou em um aumento do fluxo superficial das águas provenientes da chuva. Isto, por conseguinte, provocou alagamentos e enchentes, pois o crescimento do sistema de drenagem pluvial urbano acompanhou para expansão da cidade.

Zanella (2006), com diferente abordagem, realizou um trabalho em Curitiba que extrapolou a simples análise dos dados meteorológicos e de 
notícias na mídia impressa, utilizando os jornais Gazeta do Povo, Jornal do Estado, e O Estado do Paraná. Ela usou os jornais entender a percepção dos moradores no Bairro do Cajuru quanto às inundações que estes sofriam constantemente. A autora mostrou que a imprensa local dava mais destaque às perdas materiais do que aos desastres provocados pela chuva, sem levar em conta todo o sentimento imaterial que se perdia conjuntamente. Ela também ressalta na pesquisa 0 fato de que 0 crescimento urbano e o número de eventos pluviométricos intensos aumentaram na mesma proporção que o crescimento da ocupação de áreas de risco, principalmente os leitos dos rios.

Souza (2007) estudou a relação entre clima e saúde em ambientes urbanos, com ênfase em problemas respiratórios. O autor utilizou notícias de jornais para verificar como a imprensa mostrava os problemas de saúde enfrentados pela população. Sua pesquisa identificou uma forte conexão entre eventos climáticos extremos e suas consequências e as enfermidades do aparelho respiratório.

O trabalho de Teodoro (2008) tratou sobre planejamento urbano e problemas na cidade de Maringá (PR). Para realizar seu trabalho, o autor associou os dados de precipitação com informações obtidas nos jornais. Ele obteve como resultado a associação entre o número de notícias publicadas sobre o assunto com o aumento da precipitação.

Armond e Sant'anna Neto (2012) realizaram pesquisa correlacionando climatologia e mídia impressa, como proposta metodológica, para a cidade do Rio de Janeiro. O trabalho levou utilizou reportagens do jornal carioca $O$ Extra entre 2006 e 2010 e relacionou as reportagens com dados de precipitação. $\mathrm{Na}$ maioria das notícias os autores verificaram que a mídia impressa relatava que as chuvas eram as principais responsáveis pelos desastres. Eles ressaltam a importância de se apurar com mais precisão essa noção de causalidade entre as chuvas e os desastres. Adicionalmente, a pesquisa mostrou que as informações da mídia impressa, atreladas aos dados da Defesa Civil e de outros índices socioeconômicos podem ajudar na realização análise mais elaborada do clima na dimensão sócio-espacial. 
O Distrito Federal (DF), mesmo sendo resultante de certo planejamento, vem sofrendo há muitos anos com desastres naturais relacionados à precipitação. $O$ fato é que na região as precipitações sempre ocorreram em grande volume, por estar localizada na região intertropical. O regime climático alternadamente seco e úmido em vigência na região concentra mais de $75 \%$ das chuvas entre outubro e abril (Barros, 2003), favorecendo a ocorrência de desastres. Coelho et al. (2013, p.3) cita um exemplo:

\begin{abstract}
Por exemplo, em 1963 ocorreu um evento pluviométrico de grande intensidade (132,8 mm em 24h.) na cidade de Brasília, mas como nesta época a cidade era pouco habitada, não houve registro de desastres. Hoje se o mesmo evento ocorresse certamente alguns dos mais de 2 milhões de habitantes sofreriam com inundações, uma vez que esta vem passando por um processo intenso de ocupação desordenada acompanhado de impermeabilização do solo por meio da substituição da cobertura vegetal por asfalto e concreto.
\end{abstract}

O estudo de Steinke et al. (2006a), pesquisou a relação entre o que era divulgado na mídia e o período de estiagem no DF, encontrando vários equívocos conceituais e sensacionalismos afetam o imaginário da população brasiliense. Os autores relataram que alguns jornais locais dizem em algumas de suas reportagens que Brasília, devido à baixa umidade característica do auge do período de estiagem, possui "clima de deserto", fato que foi cientificamente refutado pelos autores, mas que é amplamente reproduzido pela população.

Steinke et al. (2006b), baseou sua pesquisa no mês extremamente chuvoso de outubro de 2006, onde a precipitação acumulada mensalmente registrou um volume de $526,4 \mathrm{~mm}$, valor $205 \%$ superior ao da Normal Climatológica e cerca de um terço do volume de precipitação acumulada que é registrada anualmente para o DF, que é de 1540,6 mm. Para tanto, foram utilizadas reportagens publicadas no jornal impresso Correio Braziliense para verificar os impactos desse mês chuvoso sobre a população e relacioná-las com os dados meteorológicos do período. Os autores constataram que a origem desse excedente pluviométrico foi um encontro excepcional e antecipado da umidade amazônica com frentes frias provenientes do Sudeste, que gerou grandes linhas de instabilidade, além da ocorrência do fenômeno 
das Zonas de Convergência do Atlântico Sul (ZCAS) e ressaltam o fato de que a rápida urbanização pela qual passou a capital é responsável pelos desastres.

Barreto (2008) analisou dos meses de fevereiro de 2004 e março de 2005 e verificou os impactos das chuvas de verão no Distrito Federal, visando encontrar as áreas vulneráveis às fortes precipitações que costumam ocorrer nessa época do ano. Para realização da pesquisa, a autora se baseou em dados da rede pluviométrica da Companhia de Saneamento Ambiental do Distrito Federal (CAESB), de infraestrutura e ocupação urbana, do Corpo de Bombeiros Militar do DF, e ainda de dados da mídia impressa local. Os resultados mostraram que as principais áreas de risco do DF são aquelas onde o relevo é dissecado, com casas próximas aos leitos dos rios, encostas e erosões, como é o caso da Vila Rabelo, Fercal, Estrutural e de condomínios e chácaras na Ceilândia; e também áreas onde a infraestrutura de drenagem pluvial é insuficiente, pois não acompanhou o crescimento da área urbana, como é o caso do Plano Piloto de Brasília.

Tavares (2008), estudou o período de 1982 a 1992 e 1999 a 2005, relacionando as notícias publicadas nos jornais de maior circulação do DF, o Correio Braziliense e o Jornal de Brasília, com dados meteorológicos. O autor constatou que no primeiro período os impactos das chuvas eram melhores abordados pelos jornais e comentados com maior cuidado, pois naquele tempo a mídia impressa não sofria concorrência de outras mídias, como a Internet. No segundo período, segundo o autor, os impactos das chuvas foram negligenciados na maioria das vezes.

Coelho et al. (2013) que estudou os impactos pluviais do ano chuvoso de 1992, utilizando também notícias do jornal Correio Braziliense para entender os impactos que a chuva de mais de $2000 \mathrm{~mm}$, registrados em algumas estações da CAESB, trouxe naquele ano atípico. Os autores constataram que o alto montante acumulado de chuva nesse ano se deu em razão da ocorrência de um forte fenômeno El Niño-Oscilação Sul que se deu no período que compreende os anos de 1990-1993. As áreas mais afetadas no período corresponderam às mesmas que Barreto (2008) havia apresentado para um 
período posterior, como Ceilândia e Samambaia, mostrando assim a reincidência dos impactos pluviais sobre essas localidades. 


\section{CARACTERIZAÇÃO DA ÁREA DE ESTUDO}

\subsection{Histórico de ocupação do Distrito Federal}

Ao final do século XIX, era latente a necessidade interiorização do Brasil, que até o momento concentrava todas as suas atividades próximas ao litoral, exceto no Sul e Sudeste. Quando se instalou a República, em 1889, foi proposta uma constituinte que culminou na constituição de 1891. Nessa constituição foi definido que haveria uma área no Planalto Central onde seria construída uma nova capital, conforme artigo da Constituição de 1891:

Art 3 - Fica pertencendo à União, no planalto central da República, uma zona de 14.400 quilômetros quadrados, que será oportunamente demarcada para nela estabelecer-se a futura Capital Federal.

Parágrafo único - Efetuada a mudança da Capital, o atual Distrito Federal passará a constituir um Estado.

(BRASIL, 1891).

A localização no Planalto Central foi adotada para garantir a soberania do território nacional, utilizando-se de uma estratégia militar milenar de ocupação das terras altas próximas às nascentes. Em 1892, Floriano Peixoto, presidente à época, chama o então diretor do Observatório Nacional, o geodésio belga Luis Cruls, para definir a área onde seria concretizada a construção desta nova capital. Cruls escolhe um quadrilátero e define então que consideraria um ponto no interior do país, próximo ao centro e com terras acima de 1000 metros, encontrando então duas possibilidades: o Espigão Mestre e a região próxima da Serra dos Pireneus. A partir de uma expedição que ficou conhecida como Missão Cruls, o pesquisador e sua equipe elaboraram o Relatório Cruls, que delineava a proposta de localização da futura capital do país no estado de Goiás, e optava pela área próxima à Serra dos Pireneus. O relatório foi apresentado, mas ficou engavetado devido à ascendência da República "Café com Leite", onde os estados de Minas Gerais, representando o leite, e São Paulo, que representava o café e era a grande força motriz da economia, não tinham interesse em transferir a capital da cidade do Rio de Janeiro para o Planalto Central por razões de cunho políticoeconômico (Cruls, 1992; Carpintero, 1998). 
Com a Revolução de 1930, Getúlio Vargas assume o poder e retoma os projetos para transferência da capital para a ocupação do interior do país e criação de um mercado interno robusto. De acordo com Carpintero (1998), para que a construção de Brasília se concretizasse, Vargas adotou algumas medidas:

- Para facilitar a cedência da área da futura capital do país, que se localizaria em uma parte do estado de Goiás, Vargas ajuda a mudança da capital desse estado, de Cidade de Goiás para Goiânia, que além de ser uma região mais próxima do quadrilátero Cruls, estaria mais integrada com o eixo econômico do estado. O governador do Goiás, Pedro Ludovico, apoia a ideia, que futuramente se mostraria uma decisão acertada por dinamizar a economia do estado. Goiânia foi fundada em 1933;

- O presidente concebe a Fundação Brasil Central, para criar cidades e povoamentos no Planalto Central que possibilitariam 0 apoio à construção da nova capital;

- Cria a Companhia Siderúrgica Nacional (CSN), em 1941, na cidade de Volta Redonda, Rio de Janeiro, visando a produção do aço que seria utilizado na construção.

Em 1945 Getúlio Vargas foi derrubado, sendo sucedido em 1946 pelo governo de Eurico Gaspar Dutra. Nesse período, foi realizada uma nova Assembleia Constituinte em 1946, onde foi novamente incluída a criação da nova capital, no ato das disposições constitucionais transitórias:

Art. 4 - A Capital da União será transferida para o planalto central do Pais.

$\S 1$ - Promulgado este Ato, o Presidente da República, dentro em sessenta dias, nomeará uma Comissão de técnicos de reconhecido valor para proceder ao estudo da localização da nova Capital.

$\S 2$ - O estudo previsto no parágrafo antecedente será encaminhado ao Congresso Nacional, que deliberará a respeito, em lei especial, e estabelecerá o prazo para o início da delimitação da área a ser incorporada ao domínio da União. 
(Brasil, 1946).

A comissão que avaliou a localização da nova capital ficou conhecida como Comissão Poli Coelho, que aprofundou os estudos de Luiz Cruls e decidiu pela construção final desta na área próxima a Serra dos Pireneus, em 1948. Após retornar ao poder democraticamente, Getúlio Vargas assina em 1953 a lei $n^{\circ} 1803$, que definia:

Art. 1ํ - É o Poder Executivo autorizado a mandar proceder, como achar conveniente, na região do Planalto Central, compreendida entre os paralelos sul $15^{\circ} 30^{\prime}$ e $17^{\circ}$ e os meridianos a W. Gr. $46^{\circ} 30^{\prime}$ e $49^{\circ}$ 30', aos estudos definitivos para a escolha do sítio da nova Capital Federal, que deverão ficar concluídos dentro de 3 (três) anos.

$\S 1$ 을 Os estudos mencionados neste artigo deverão satisfazer às seguintes condições:

a) clima e salubridade favoráveis;

b) facilidade de abastecimento de água e energia elétrica;

c) facilidade de acesso às vias de transporte terrestres e aéreas;

d) topografia adequada;

e) solo favorável às edificações e existência de materiais de construção;

f) proximidade de terras para cultura;

g) paisagem atraente.

$\S 2^{\circ}$ Os estudos serão feitos na base de uma cidade para 500.000 habitantes.

§ 3o O prazo para o início dêstes estudos será de 60 (sessenta) dias, a contar da vigência desta Lei.

Art $2^{\circ}$ Em torno dêste sítio será demarcada, adotados os limites naturais ou não, uma área aproximada de $5.000 \mathrm{~km}^{2}$ (cinco mil quilômetros quadrados), que deverá conter, da melhor forma, os requisitos necessários à constituição do Distrito Federal e que será incorporado ao Patrimônio da União.

Art 3ㅇ O Govêrno Federal mandará realizar estudos definitivos sôbre as condições do abastecimento de água e energia elétrica; reconhecimento sôbre o estabelecimento do plano rodoferroviário, que deverá ligar a futura capital a todos os Estados, com sua adaptação ao Plano Geral de Viação Nacional; o estudo definitivo das vias de transportes necessárias à efetivação da mudança da Capital; 
o plano de desapropriações das áreas necessárias e o plano urbanístico da nova Capital.

Art $4{ }^{\circ} \mathrm{O}$ Govêrno Federal mandará estudar pela sua Secretaria e por cada uma dos Ministérios o plano de sua mudança para a futura capital e dos órgãos ou representações que the são inerentes, assim como os efeitos da medida sôbre os Departamentos subsidiários, sediados nos diversos pontos do território nacional.

Art 5ㅇ O Govêrno Federal mandará estudar, pelo órgão competente, o problema da transferência dos Poderes Legislativo e Judiciário, assim como do funcionalismo público federal e sua instalação na nova Capital.

Art $6^{\circ}$ Os planos parciais constituirão o Plano Geral da Mudança da Capital e poderão ser encaminhados, por etapas, à aprovação do Congresso, conforme o exigirem circunstâncias e a urgência de execução de cada um.

Art 7ํㅡ Govêrno Federal mandará estudar a situação decorrente da transferência da sede do Govêrno para o atual Distrito Federal e a organização do novo Estado da Guanabara, previsto na Constituição.

Art 8 É o Poder Executivo autorizado a abrir, pelo Ministério da Viação e Obras Públicas, o crédito especial de Cr $\$ 20.000 .000,00$ (vinte milhões de cruzeiros), para atender aos encargos criados por esta Lei.

(BRASIL, 1953).

Para realizar os estudos técnicos da área onde seria construída a cidade (e não o quadrilátero), Getúlio Vargas contratou a empresa americana Donald J. Belcher and Associates, que realizava levantamento de dados por meio de aerofotogrametria, que entregou em 1955 o Relatório técnico sobre a Nova Capital da República, que ficou conhecido como Relatório Belcher, onde definia cinco possíveis sítios para a construção da nova capital. A comissão de transferência da nova capital optou pelo sítio castanho, na região que ficava mais próxima ao centro do quadrilátero. Entretanto, antes da entrega do Relatório Belcher, em 1954, o presidente Vargas se suicidou por pressões políticas que vinha sofrendo e o vice-presidente Café Filho assumiu a presidência no período até ter um infarto em 1955. No hiato político que se instaurou, os trabalhos ficaram paralisados, até que em 1956, Juscelino Kubitschek (JK), presidente eleito, tomou posse (Carpintero, 1998). 
A meta síntese do governo de JK era a construção da nova capital, sendo que ao assumir, o presidente age rapidamente para que Brasília fosse construída, criando a Companhia Urbanizadora da Nova Capital do Brasil (NOVACAP), instituição que seria responsável pela transferência da capital do Rio de Janeiro para Brasília, tendo como presidente Israel Pinheiro e diretor técnico o arquiteto Oscar Niemeyer. A NOVACAP, por sua vez, lançou o edital do concurso para construção da nova capital, voltada para escolha do projeto da cidade, onde só permitia equipes nacionais, lideradas por arquitetos ou engenheiros, e exigia a apresentação das equipes de um mapa na escala 1:25.000 e um relatório explicativo. Poderiam ser apresentados também detalhamentos como abastecimento de água e energia. A área urbana deveria ser projetada para apenas 500.000 habitantes e era fornecida uma cópia para os concorrentes dos relatórios Crulz e Belcher, contendo também os mapas com a localização da represa do Paranoá e do aeroporto (Carpintero, 1998).

A equipe vencedora foi a do arquiteto e urbanista Lúcio Costa, que se baseou na topografia do sítio escolhido para fazer o traçado da cidade, que se assemelha ao formato de um avião, utilizando o conceito de cidade linear, onde uma via central é criada e permite o crescimento da cidade a partir do eixo rodoviário. Costa também se baseou conceito de cidade jardim, de Ebenezer Howard, para criar as superquadras. Para que a construção da cidade pudesse ocorrer em tempo recorde, foi necessário pular a etapa de planejamento de dimensionamento do espaço dos ministérios e outros órgãos que seriam transferidos, o que ocasionou futuramente a insuficiência de escritórios na Esplanada, já que mais ministérios foram criados (CARPINTERO,1998).

Após a definição do projeto a NOVACAP iniciou e organizou a construção de Brasília, que foi inaugurada em 21 de abril de 1960, com a maioria dos prédios administrativos sendo projetados de acordo com a arquitetura modernista de Oscar Niemeyer. Desde então, o Distrito Federal vem passando por um intenso processo de urbanização. Foram criadas por Israel Pinheiro as cidades-satélites, hoje conhecidas como Regiões 


\begin{tabular}{|c|c|c|c|c|c|}
\hline Ano & $\begin{array}{c}\text { População } \\
\text { Urbana }\end{array}$ & $\begin{array}{c}\text { População } \\
\text { Urbana (\%) }\end{array}$ & $\begin{array}{c}\text { População } \\
\text { Rural }\end{array}$ & $\begin{array}{c}\text { População } \\
\text { Rural (\%) }\end{array}$ & $\begin{array}{c}\text { População } \\
\text { Total }\end{array}$ \\
\hline $\mathbf{1 9 6 0}$ & 88.334 & 63,02 & 51.830 & 36,98 & 140.164 \\
\hline $\mathbf{1 9 7 0}$ & 516.082 & 96,02 & 21.410 & 3,98 & 537.492 \\
\hline $\mathbf{1 9 8 0}$ & 1.139 .031 & 96,78 & 37.904 & 3,22 & 1.176 .935 \\
\hline $\mathbf{1 9 9 1}$ & 1.515 .889 & 94,68 & 85.205 & 5,32 & 1.601 .094 \\
\hline $\mathbf{2 0 0 0}$ & 1.954 .442 & 95,66 & 88.727 & 4,34 & 2.043 .169 \\
\hline $\mathbf{2 0 1 0}$ & 2.476 .249 & 96,62 & 86.714 & 3,38 & 2.562 .963 \\
\hline
\end{tabular}

Administrativas, para acomodar a crescente população que já não cabia no Plano Piloto. Na década de 70, conforme o Quadro 1, a população já havia ultrapassado os 500 mil habitantes, com várias invasões próximas à área central que foram transferidas para as cidades-satélites.

Quadro 1. Quadro de crescimento da população no Distrito Federal conforme censos demográficos realizados. Fonte dos dados: Censos Demográficos do IBGE. Elaborado pelo autor.

Atualmente, mais de 50 anos após sua fundação, o DF possui mais do que o quíntuplo da população para o qual foi projetado (quase 2.6 milhões de habitantes), fruto da crescente expansão e especulação imobiliária que atuam sobre a região e seu Entorno. O crescimento desordenado ocasionou diversos problemas na área urbana, sendo a chuva um sério agravante desses problemas.

\subsection{Localização e delimitação da área de estudo}

A área utilizada para este trabalho corresponde ao Distrito Federal (DF), localizado no Planalto Central do Brasil, na região Centro-Oeste. De acordo com o Instituto Brasileiro de Geografia e Estatística (IBGE) o DF possui área de $5.802 \mathrm{~km}^{2}$, tendo como limítrofes: o paralelo $15^{\circ} 30^{\prime} \mathrm{S}$ ao Norte, o paralelo $16^{\circ}$ 03' S ao Sul, a Leste o rio Preto e a Oeste o rio Descoberto. O DF também é compreendido politicamente em 31 Regiões Administrativas (Figura 7). 


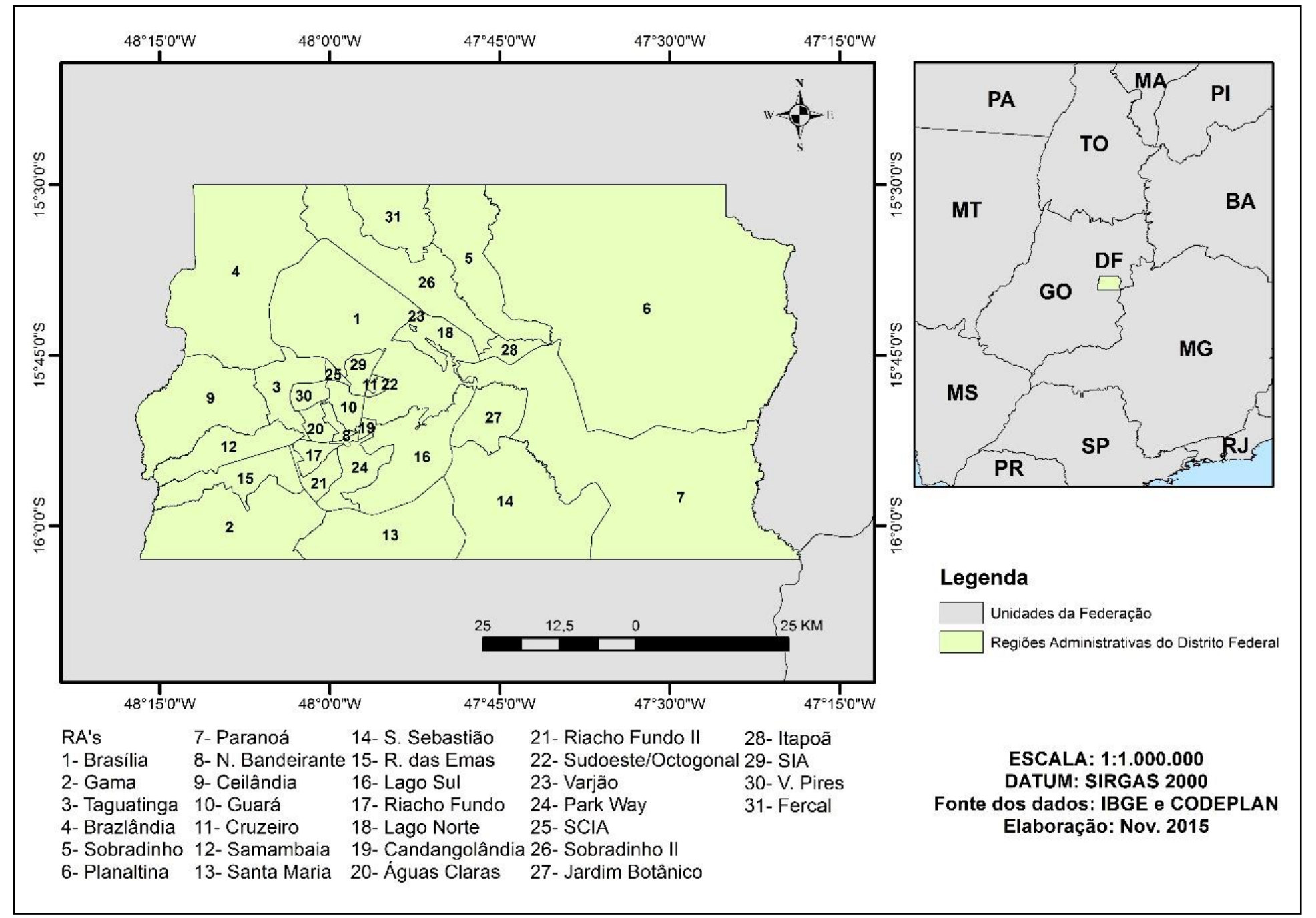

Figura 7. Mapa das Regiões Administrativas do Distrito Federal em sua atual configuração. Fonte dos dados: IBGE / CODEPLAN. 


\subsection{Caracterização física da região}

Com relação à formação geológica, o DF está localizado na faixa de dobramentos Brasília, sendo composta por rochas metassedimentares dos grupos Canastra, Paranoá, Araxá e Bambuí. Há predominância dos solos dos tipos Latossolo Vermelho (LV), Latossolo Vermelho-Amarelo (LVA) e Cambissolos (C), os quais representam $85,49 \%$ dos solos presentes no território do DF. Os outros tipos de solo que ocorrem no DF são o Argissolos, Nitossolos, Neossolos Flúvicos, Gleissolos e Neossolos Quartzarêncos (Martins et al., 2004).

Steinke (2003) dividiu as unidades morfológicas do Distrito Federal em quatro padrões segundo o grau de dissecação do relevo e a posição altimétrica, a saber: Padrão Aplainado Superior; Padrão Aplainado Inferior; Padrão em Colinas e Padrão Dissecado. Esses padrões condicionam a hidrografia da região, cujos cursos d'água pertencem às três Regiões Hidrográficas mais importantes da América do Sul: a bacia do Paraná (Rio São Bartolomeu, Lago Paranoá, Rio Descoberto, Rio Corumbá e Rio São Marcos), bacia do São Francisco (Rio Preto) e bacia do Tocantins (Rio Maranhão). padrão encontrado determina a ocorrência de rios de planalto e de grande quantidade de canais de primeira ordem e de nascentes.

Já a caracterização do clima no Distrito Federal está sujeita à predominância das seguintes massas de ar: massa Tropical Atlântica (mTa) que, devido à ação persistente do Anticiclone Semifixo do Atlântico Sul, possui atuação relevante durante 0 ano todo. Durante o verão a massa Equatorial Continental $(\mathrm{mEc})$, atraída pelos sistemas depressionários do interior do continente, como a Baixa do Chaco, tende a avançar do NW, ora para SE, ora para ESE, atingindo a região, onde provoca elevação das temperaturas, sendo responsável ainda pelo aumento da umidade e das precipitações. Essas massas de ar, associados à posição geográfica da região permitem observar dois períodos marcantes, um seco e outro chuvoso. De maneira geral é possível afirmar que o período compreendido entre os meses de maio a setembro (seco) possui as seguintes características: intensa insolação, pouca nebulosidade, forte evaporação, baixos teores de umidade no ar, pluviosidade reduzida e grande amplitude térmica (máximas elevadas e mínimas reduzidas). 
O inverso se dá no semestre outubro a abril (período chuvoso): a insolação se reduz, a nebulosidade aumenta, diminui a evaporação, os teores de umidade do ar e a pluviosidade aumentam, e a amplitude térmica reduz-se, pois as máximas mantêm-se e as mínimas elevam-se (Nimer, 1989). O comportamento anual da chuva e da temperatura do ar no Distrito Federal é mostrado no gráfico 8.

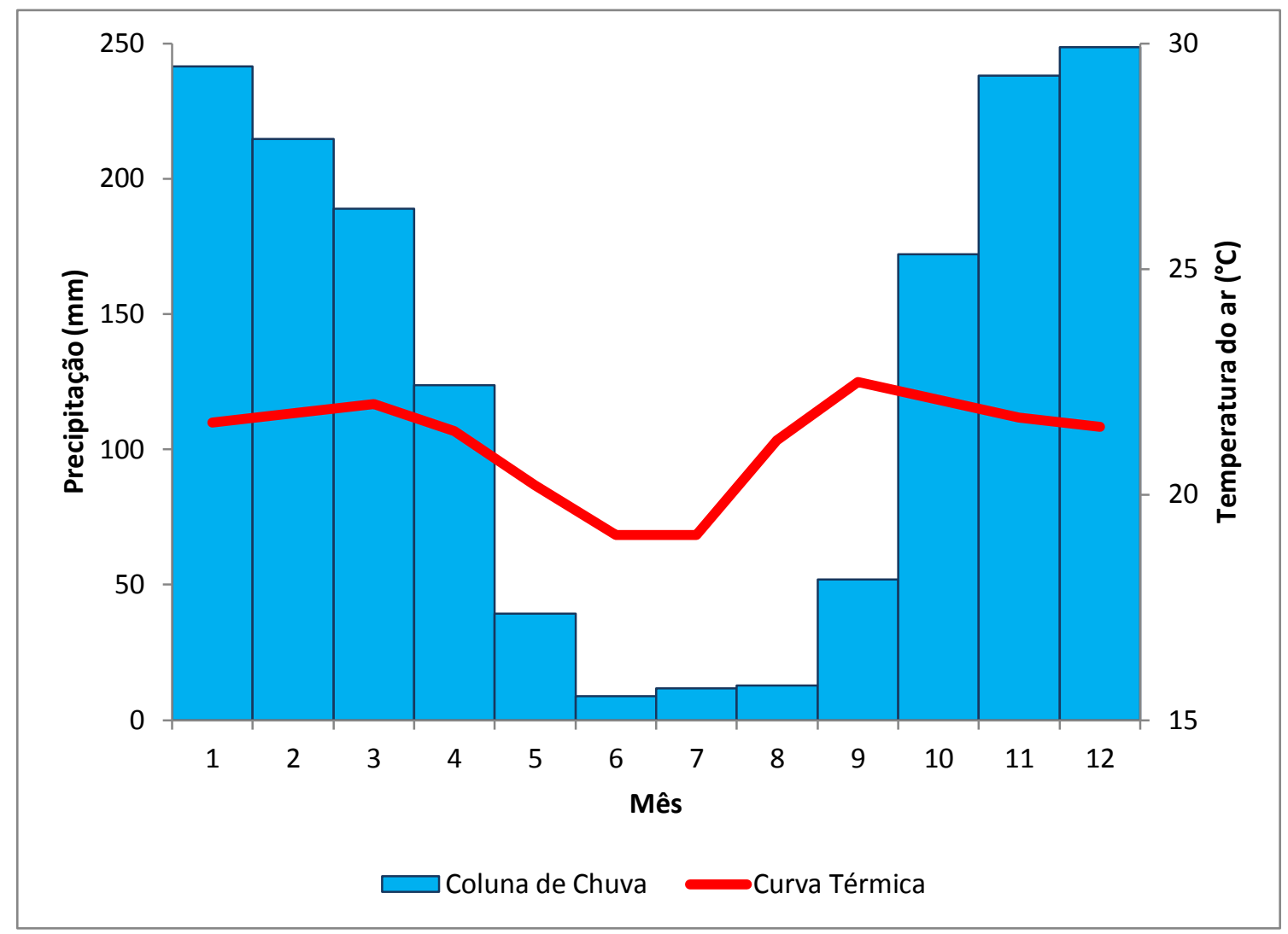

Gráfico 8. Variação anual do total mensal de precipitação e da média mensal da temperatura do ar no Distrito Federal no período de 1961 a 1990. Fonte dos dados: Normais Climatológicas 1961-1990. Elaborado pelo autor.

Quanto à vegetação, segundo a Secretaria de Meio Ambiente e Recursos Hídricos SEMARH (2000), a área de estudo situa-se na região do Cerrado e apresenta diferentes tipos de vegetação, tais como: Cerradão, Cerrado Típico, Campo Cerrado, Campo Sujo e Campo Limpo, Matas Ciliares, Veredas e Campos Rupestres. 


\section{PROCEDIMENTOS METOLÓGICOS}

O desenvolvimento da pesquisa foi organizado em três etapas, conforme é mostrado na Figura 12.

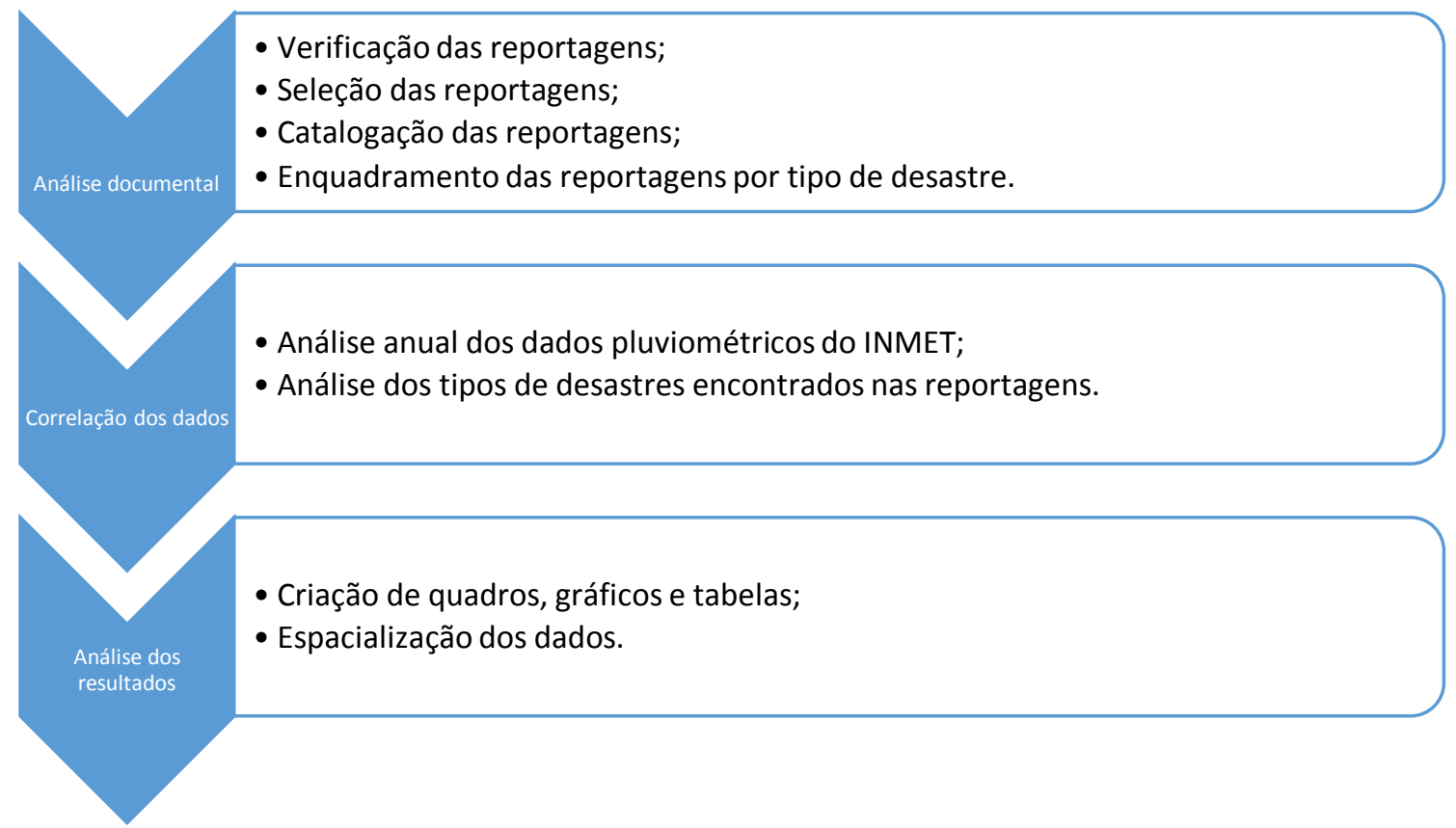

Figura 8. Organograma da dissertação.

Fonte: Elaborado pelo autor.

Na primeira etapa foi realizada a análise documental sobre desastres naturais relacionados à precipitação. $O$ documento usado foi o principal jornal impresso do Distrito Federal, o Correio Braziliense. Esse procedimento consiste em:

- Verificar todas as edições diárias publicadas entre 2000 e 2010, pelo acesso no Centro de Documentação do jornal e pela busca no sistema Busca CB na Internet;

- Selecionar todas as notícias referentes a desastres naturais associados à precipitação publicadas entre 2000 e 2010;

- Catalogar cada notícia selecionada em um banco de dados, no qual as notícias foram classificadas e listadas de acordo com a data, a página, o caderno do jornal, a ocorrência ou não de fotos, o título da notícia, informações adicionais (que relatam apenas dados pontuais e 
relevantes das notícias), tipo de desastre associado às chuvas, a RA afetada e a referência bibliográfica da notícia;

- Os desastres naturais citados nas reportagens foram enquadrados em categorias, utilizando parte da classificação de desastres naturais do CEPED (2013). Nem todos os tipos de desastres caberão à pesquisa porque nem todos os enumerados pela publicação estão associados à ocorrência de chuvas. Serão utilizados os seguintes tipos desastres: enxurrada; alagamento; vendaval; granizo; movimento de massa; erosão.

A escolha deste jornal se deveu ao fato de o Correio Brazilense ser publicado diariamente desde 1960, ano de fundação de Brasília. Um importante registro histórico dos fenômenos meteorológicos ocorridos na cidade está contido em seu acervo. Além disso, não são encontradas em outras fontes relatos semelhantes e com tanta riqueza de detalhes sobre os problemas urbanos relacionados à chuva. Esses aspectos conferem credibilidade às informações apresentadas e permitem a identificação de fatos relevantes para a pesquisa, conforme aponta Coelho et al. (2013). Adicionalmente, esse acervo tem a vantagem de ser acessível por meio da Internet.

$\mathrm{Na}$ segunda etapa foi realizada a análise das tabelas, separando os desastres naturais por ano, tipo e quantidade de reportagens encontradas. Durante essa etapa também foi realizada a correlação dos entre as reportagens selecionadas com as estações pluviométricas do INMET, anualmente. Essa etapa tem como intuito verificar se o comportamento da pluviometria acompanhou a quantidade de desastres que ocorreram entre 2000 e 2010. 


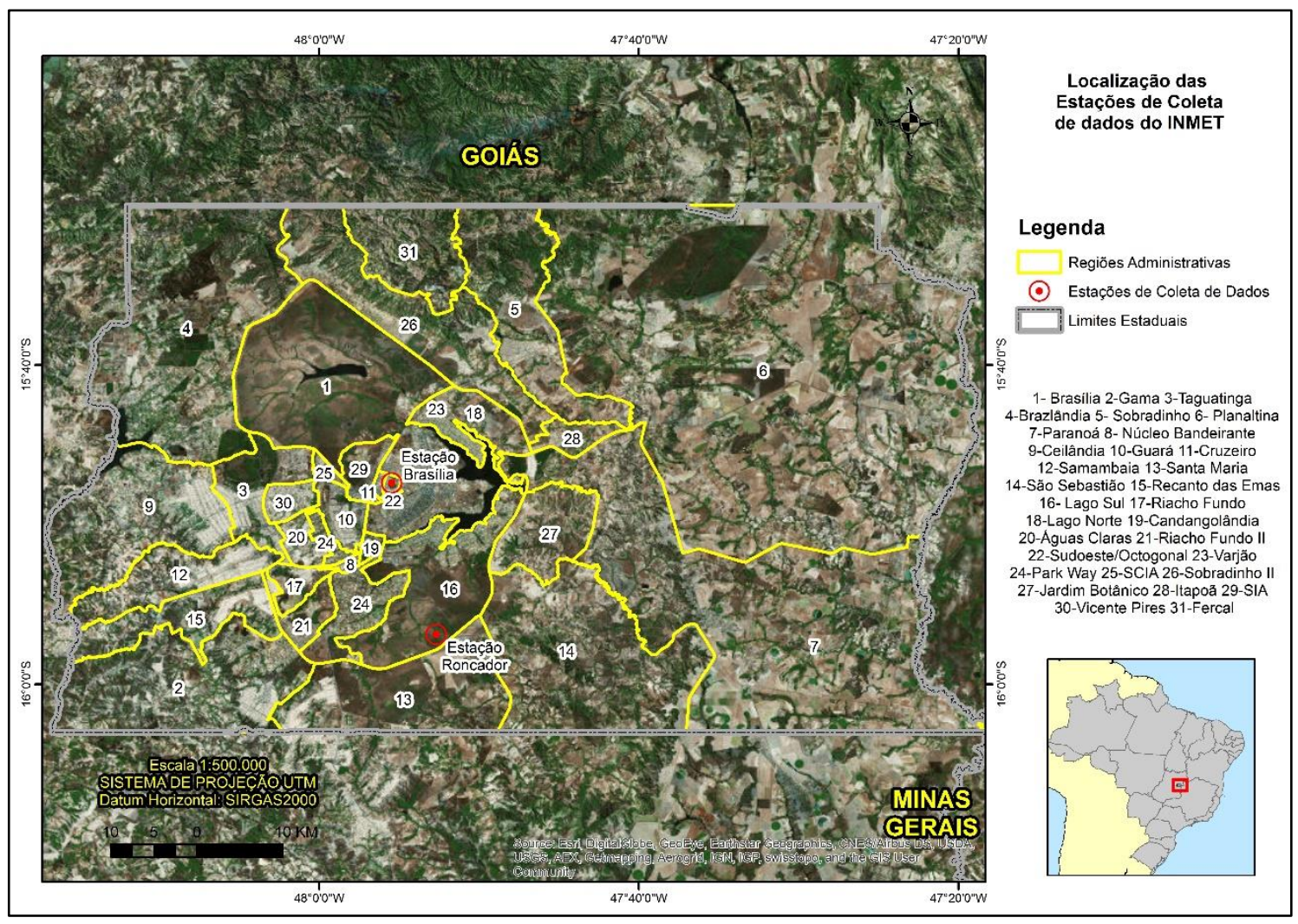

Figura 9. Mapa de distribuição das estações meteorológicas do INMET no DF. Elaborado por Lucas Garcia Magalhães Peres.

A terceira e última etapa consistirá na análise e discussão dos resultados. Nessa etapa foram criados gráficos e quadros e foi realizada a espacialização dos dados. A análise foi realizada ano a ano. 


\section{RESULTADOS E DISCUSSÃO}

\subsection{Análise anual}

\subsubsection{Ano de 2000}

O ano de 2000 foi um ano com chuva espacialmente variáveis, tendo registrado na Estação Brasília do INMET um total de precipitação acumulada anualmente de 1377,3 mm de chuva (Gráfico 9), aproximadamente 11,6\% abaixo da Normal Climatológica de precipitação e na Estação Roncador do INMET, $1696 \mathrm{~mm}$, cerca de 10\% acima da Normal, que é de 1540,6 mm (Gráfico 10).

No período chuvoso, ou seja, de novembro a abril, os gráficos de precipitação acumulada mensalmente mostram que em janeiro e fevereiro os valores ficaram abaixo da Normal, superando e igualando-se a ela nos meses de março e abril, respectivamente. Em agosto e setembro as chuvas superaram a Normal, indício de que o período chuvoso começou mais cedo, e permaneceram acima da média em outubro e novembro na área urbana (Estação Brasília), caindo em dezembro. Na área da Estação Roncador, que está localizada numa área de proteção ambiental bem preservada, a precipitação do outubro foi abaixo da Normal, mas a superou nos meses de novembro e dezembro.

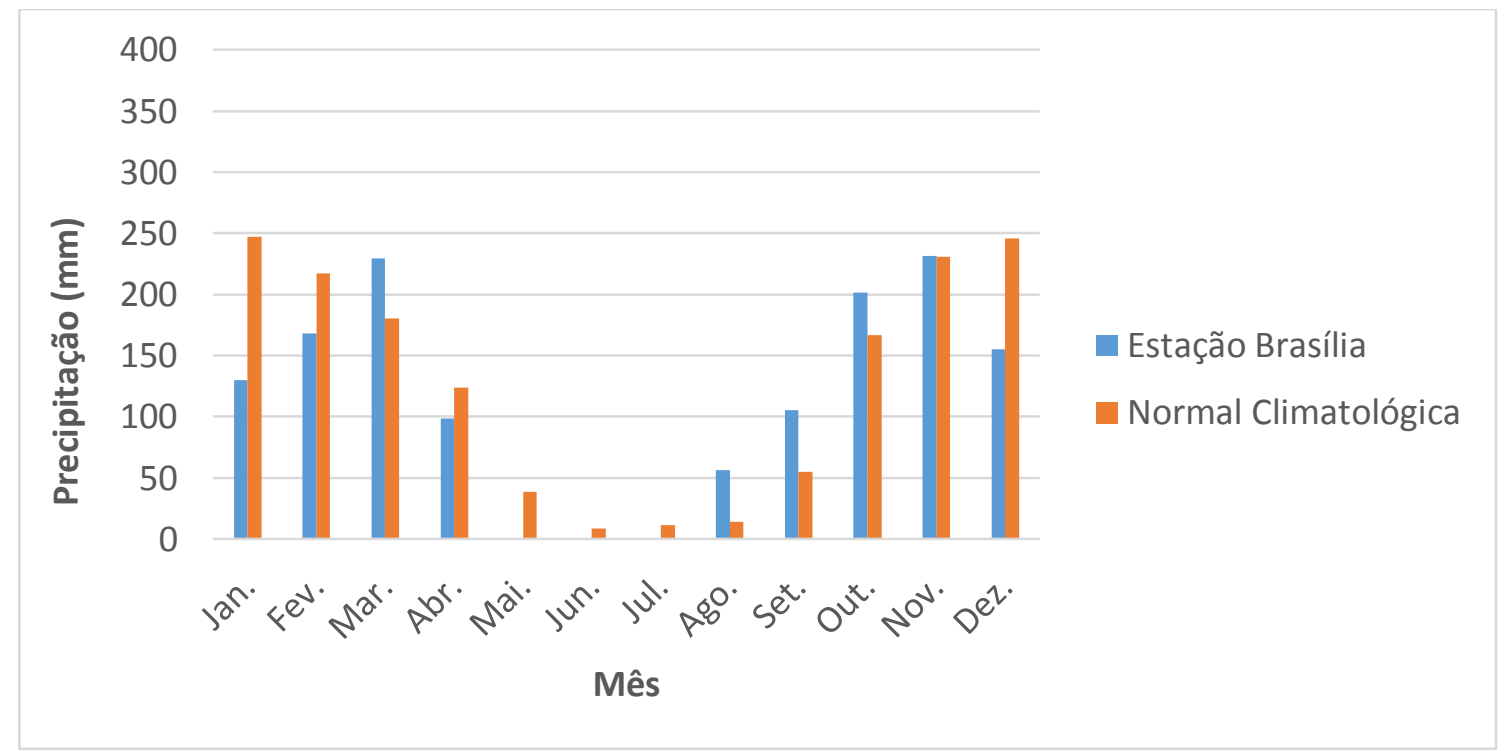

Gráfico 9. Precipitação mensal acumulada em 2000 na Estação Brasília do INMET (DF). 


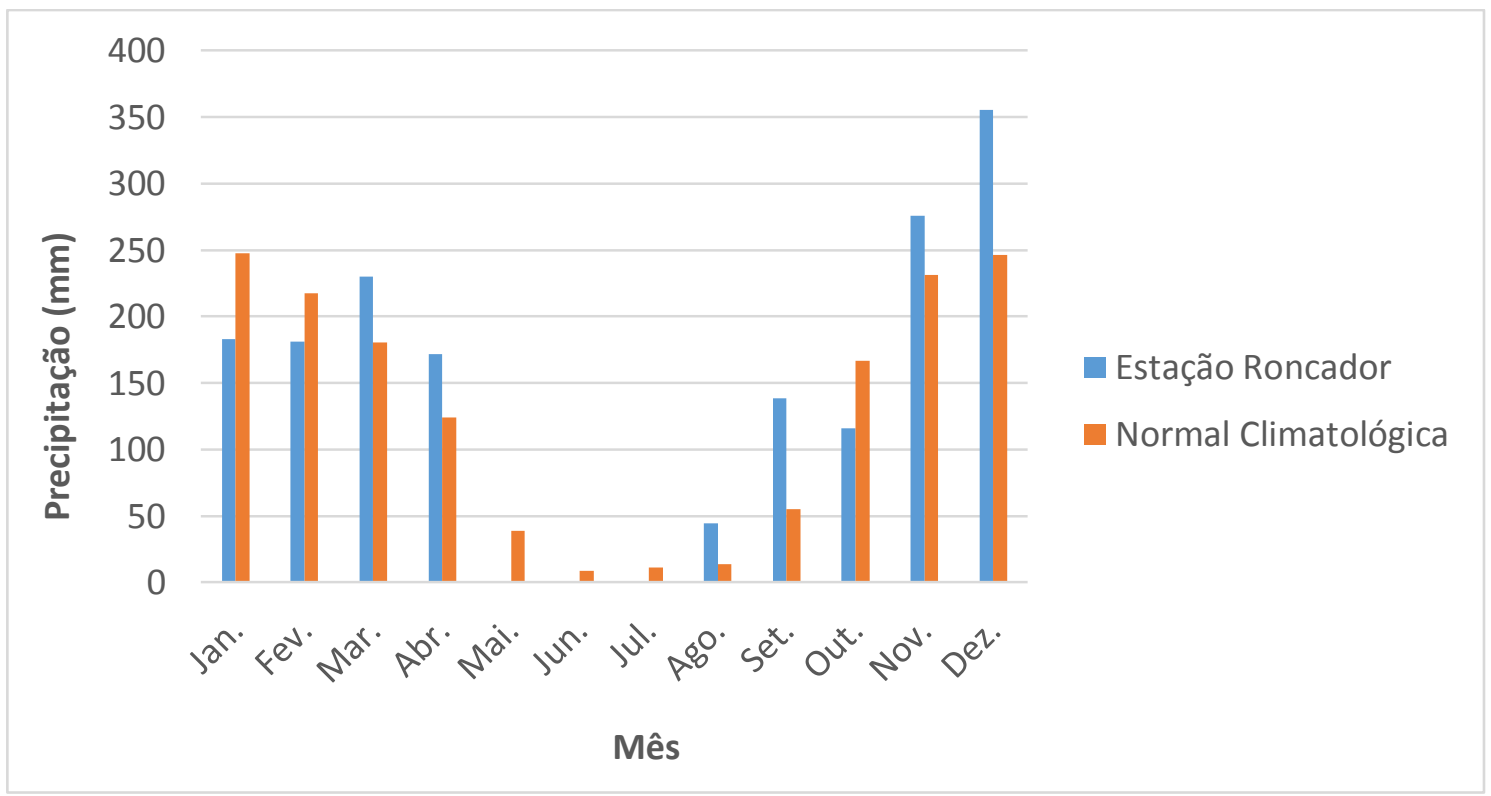

Gráfico 10. Precipitação mensal acumulada em 2000 na Estação Roncador do INMET (DF).

Em 2000 foram encontradas 14 reportagens referentes à desastres naturais associados às precipitações, observando-se que a maior quantidade de notícias se deu nos meses de janeiro, com 4 reportagens, e outubro, com 3 reportagens, como pode ser aferido no Gráfico 11 e no Apêndice I.

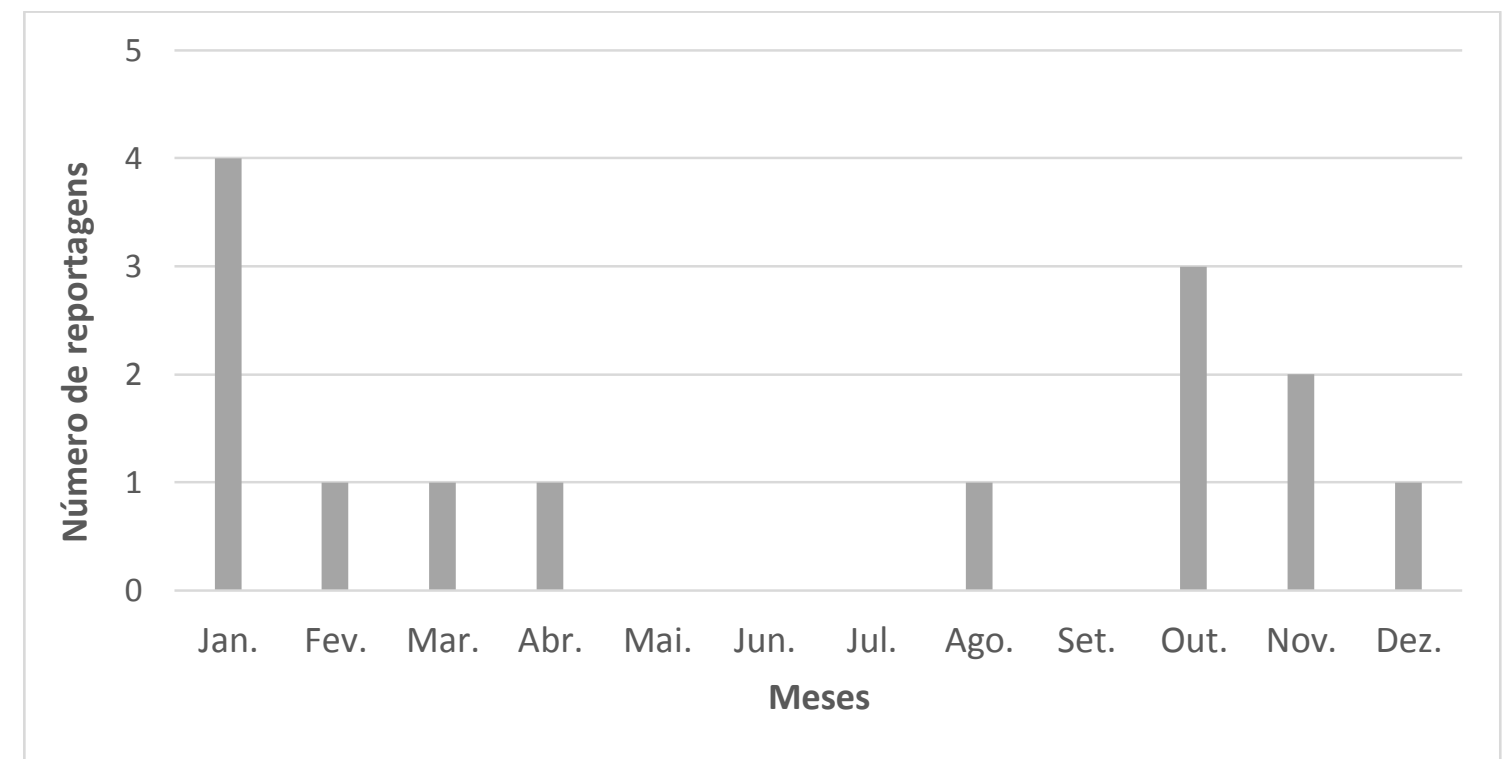

Gráfico 11. Número de reportagens encontradas mensalmente em 2000. Fonte dos dados: Correio Braziliense. Elaborado pelo autor.

De acordo com o que foi registrado nas reportagens (Quadro 2), a Região Administrativa mais afetada foi o Recanto das Emas (RA XV), com 7 ocorrências de desastres. Ceilândia (RA XI) e Samambaia (RA XII) tiveram 6 
ocorrências de desastres, e Taguatinga (RA III), 5 ocorrências. É importante salientar que à época Águas Claras (RA XX) e Vicente Pires (RA XXX) ainda não haviam sido desmembradas de Taguatinga (RA III), mas para todos os efeitos, sempre que foram identificados desastres nessas RA's estes foram contabilizados devidamente nos seus nomes específicos para facilitar a visualização.

\begin{tabular}{|c|c|c|c|c|c|c|c|}
\hline $\begin{array}{l}\text { Região } \\
\text { Administrativa }\end{array}$ & Alagam. & Enx. & Erosão & Granizo & $\begin{array}{l}\text { Movimento } \\
\text { de Massa }\end{array}$ & Vendaval & Total \\
\hline $\begin{array}{l}\text { Plano Piloto } \\
\text { (RA I) }\end{array}$ & 3 & 0 & 0 & 0 & 0 & 0 & 3 \\
\hline Gama (RA II) & 0 & 0 & 0 & 0 & 0 & 0 & 0 \\
\hline $\begin{array}{l}\text { Taguatinga } \\
\text { (RA III) }\end{array}$ & 1 & 2 & 0 & 0 & 0 & 2 & 5 \\
\hline $\begin{array}{l}\text { Brazlândia } \\
\text { (RA IV) }\end{array}$ & 1 & 1 & 0 & 0 & 0 & 0 & 2 \\
\hline $\begin{array}{l}\text { Sobradinho } \\
\text { (RA V) }\end{array}$ & 0 & 0 & 0 & 0 & 0 & 0 & 0 \\
\hline $\begin{array}{l}\text { Planaltina (RA } \\
\text { VI) }\end{array}$ & 1 & 1 & 1 & 0 & 0 & 0 & 3 \\
\hline $\begin{array}{l}\text { Paranoá (RA } \\
\text { VII) }\end{array}$ & 0 & 0 & 0 & 0 & 0 & 0 & 0 \\
\hline Núcleo & & & & & & & \\
\hline $\begin{array}{l}\text { Bandeirante } \\
\text { (RA VIII) }\end{array}$ & 0 & 0 & 0 & 0 & 0 & 0 & 0 \\
\hline $\begin{array}{l}\text { Ceilândia (RA } \\
\text { IX) }\end{array}$ & 2 & 2 & 0 & 0 & 0 & 2 & 6 \\
\hline Guará (RA X) & 0 & 0 & 1 & 0 & 0 & & 1 \\
\hline Cruzeiro (RA XI) & 2 & 1 & 0 & 0 & 0 & 1 & 4 \\
\hline $\begin{array}{l}\text { Samambaia } \\
\text { (RA XII) }\end{array}$ & 2 & 2 & & 0 & 0 & 2 & 6 \\
\hline $\begin{array}{l}\text { Santa Maria } \\
\text { (RA XIII) }\end{array}$ & 1 & 1 & 1 & 0 & 0 & 1 & 4 \\
\hline $\begin{array}{l}\text { São Sebastião } \\
\text { (RA XIV) }\end{array}$ & 0 & 0 & 0 & 0 & 0 & 0 & 0 \\
\hline $\begin{array}{l}\text { Recanto das } \\
\text { Emas (RA XV) }\end{array}$ & 2 & 2 & 2 & 0 & 0 & 1 & 7 \\
\hline $\begin{array}{l}\text { Lago Sul (RA } \\
\text { XVI) }\end{array}$ & 0 & 0 & 0 & 0 & 0 & 0 & 0 \\
\hline $\begin{array}{l}\text { Riacho Fundo } \\
\text { (RA XVII) }\end{array}$ & 0 & 0 & 0 & 0 & 0 & 0 & 0 \\
\hline $\begin{array}{l}\text { Lago Norte (RA } \\
\text { XVIII) }\end{array}$ & 0 & 0 & 0 & 0 & 0 & 0 & 0 \\
\hline $\begin{array}{l}\text { Candangolândia } \\
\text { (RA XIX) }\end{array}$ & 0 & 0 & 0 & 0 & 0 & 0 & 0 \\
\hline $\begin{array}{l}\text { Águas Claras } \\
\text { (RA XX) }\end{array}$ & 0 & 0 & 0 & 0 & 0 & 0 & 0 \\
\hline $\begin{array}{l}\text { Riacho Fundo II } \\
\text { (RA XXI) }\end{array}$ & 0 & 0 & 0 & 0 & 0 & 0 & 0 \\
\hline $\begin{array}{l}\text { Sudoeste / } \\
\text { Octogonal (RA } \\
\text { XXII) }\end{array}$ & 1 & 0 & 0 & 0 & 0 & 1 & 2 \\
\hline
\end{tabular}




\begin{tabular}{|c|c|c|c|c|c|c|c|}
\hline $\begin{array}{l}\text { Varjão (RA } \\
\text { XXIII) }\end{array}$ & 0 & 0 & 0 & 0 & 0 & 0 & 0 \\
\hline $\begin{array}{l}\text { Park Way (RA } \\
\text { XXIV) }\end{array}$ & 0 & 0 & 0 & 0 & 0 & 0 & 0 \\
\hline $\begin{array}{l}\text { Setor } \\
\text { Complementar } \\
\text { de Indústria e } \\
\text { Abastecimento } \\
\text { (RA XXV) }\end{array}$ & 0 & 0 & 0 & 0 & 0 & 0 & 0 \\
\hline $\begin{array}{l}\text { Sobradinho II } \\
\text { (RA XXVI) }\end{array}$ & 0 & 0 & 0 & 0 & 0 & 0 & 0 \\
\hline $\begin{array}{l}\text { Jardim Botânico } \\
\text { (RA XXVII) }\end{array}$ & 0 & 0 & 0 & 0 & 0 & 0 & 0 \\
\hline $\begin{array}{l}\text { Itapoã (RA } \\
\text { XXVII) }\end{array}$ & 0 & 0 & 0 & 0 & 0 & 0 & 0 \\
\hline $\begin{array}{l}\text { Setor de } \\
\text { Indústria e } \\
\text { Abastecimento } \\
\text { (RA XXIX) }\end{array}$ & 0 & 0 & 0 & 0 & 0 & 1 & 1 \\
\hline $\begin{array}{l}\text { Vicente Pires } \\
\text { (RA XXX) }\end{array}$ & 0 & 0 & 0 & 0 & 0 & 0 & 0 \\
\hline Fercal (RA XXXI) & 0 & 0 & 0 & 0 & 0 & 0 & 0 \\
\hline Total & 16 & 12 & 5 & 0 & 0 & 11 & 44 \\
\hline
\end{tabular}

Quadro 2. Número de reportagens encontradas mensalmente em 2000 com tipologia de desastres naturais. Elaborado pelo autor.

Em relação à tipologia de desastres naturais, os alagamentos foram os desastres naturais que ocorreram com maior frequência, sendo observados 16 vezes nas Regiões Administrativas; seguidos por enxurradas, com 12 ocorrências; vendavais, com 11 ocorrências e erosão, com 5 ocorrências. As porcentagens de cada tipo de desastres podem ser observadas no Gráfico 12.

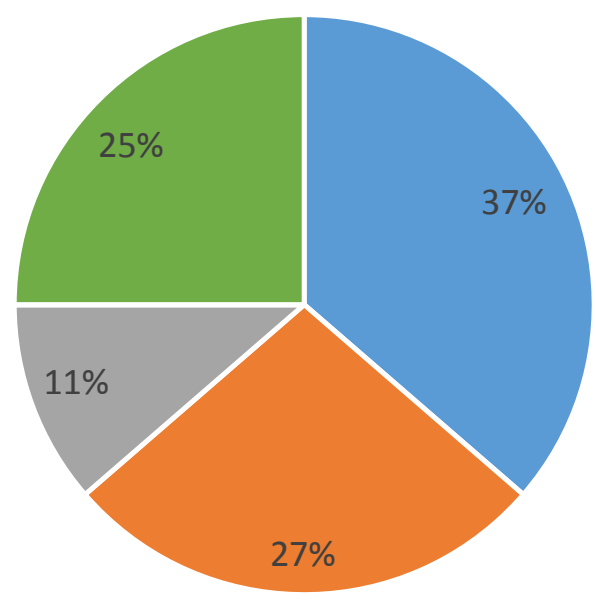

- Alagamento

- Enxurrada

- Erosão

- Vendaval

Gráfico 12. Porcentagem de desastres naturais encontrados nas reportagens ocorridos em 2000. Elaborado pelo autor. 
Dentre as reportagens analisadas, duas se destacam. Em Brazlândia (RA IV), um temporal alagou mais de cem casas na Quadra 6 (Figura 10). De acordo com a reportagem, naquele período a área urbana ainda não possuía rede de captação de águas pluviais, o que aliado à impermeabilização do solo, resíduos sólidos e falta de áreas de escoamento superficial provocou o alagamento.
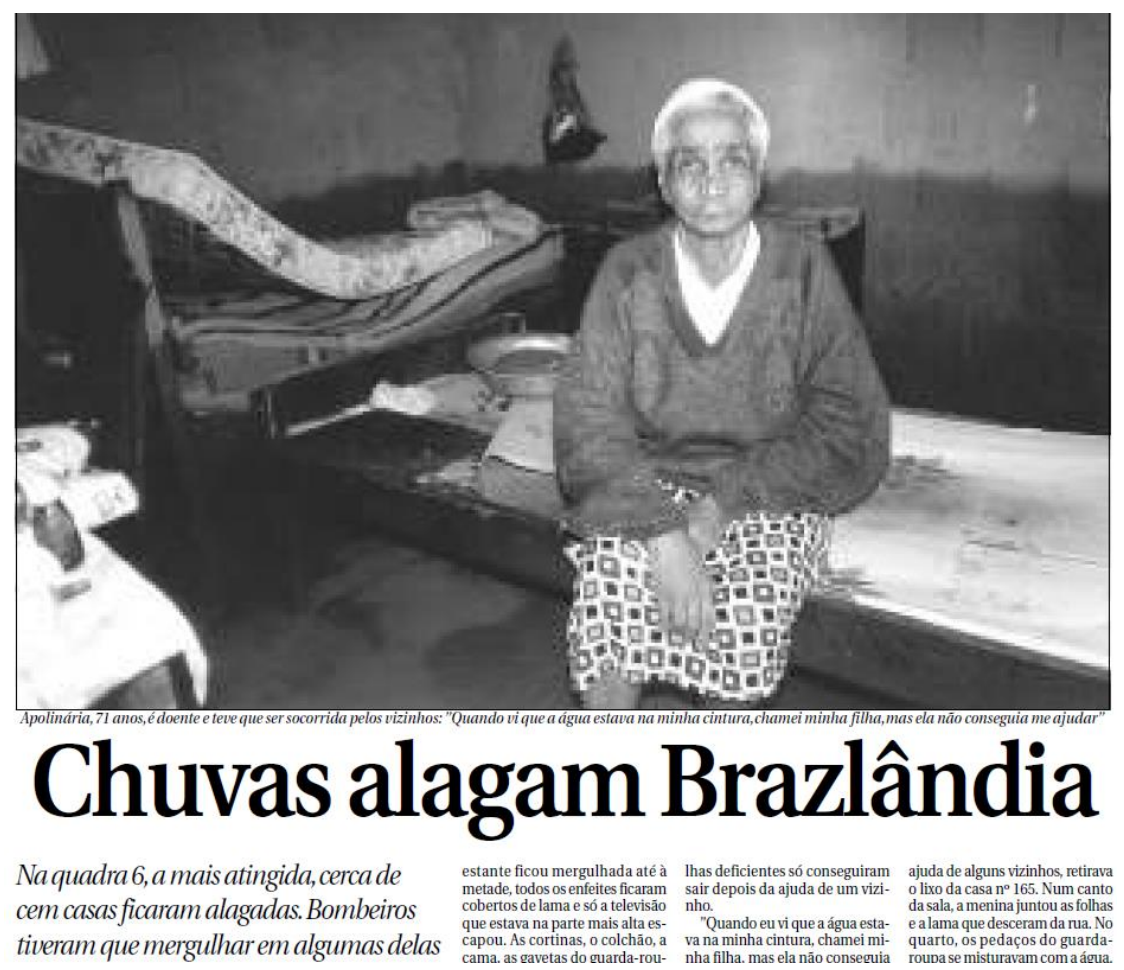

Figura 10. Recorte de reportagem de janeiro de 2000 (Apêndice I, Notícia no 2). Fonte: Correio Braziliense.

Em Santa Maria (RA XIII), as enxurradas mostram como os desastres naturais impactam diretamente a população mais carente, que não tem muita capacidade de resiliência aos desastres. Durante uma forte chuva, três homens que atravessavam uma ponte improvisada foram carregados por uma enxurrada durante uma forte chuva que caiu na região (Figura 11). Um deles veio a óbito, o que preocupou a vizinhança local devido à quantidade de crianças que passava pelo local. Costa (2011) aponta que a população ocupou inicialmente a RA de maneira irregular, na forma de invasão. Somente depois que já estava ocupado o espaço foi regularizado e recebeu a devida urbanização, e enquanto se urbanizou, Santa Maria enfrentou diversos desastres. 


\section{A chuva, a erosão e a morte}

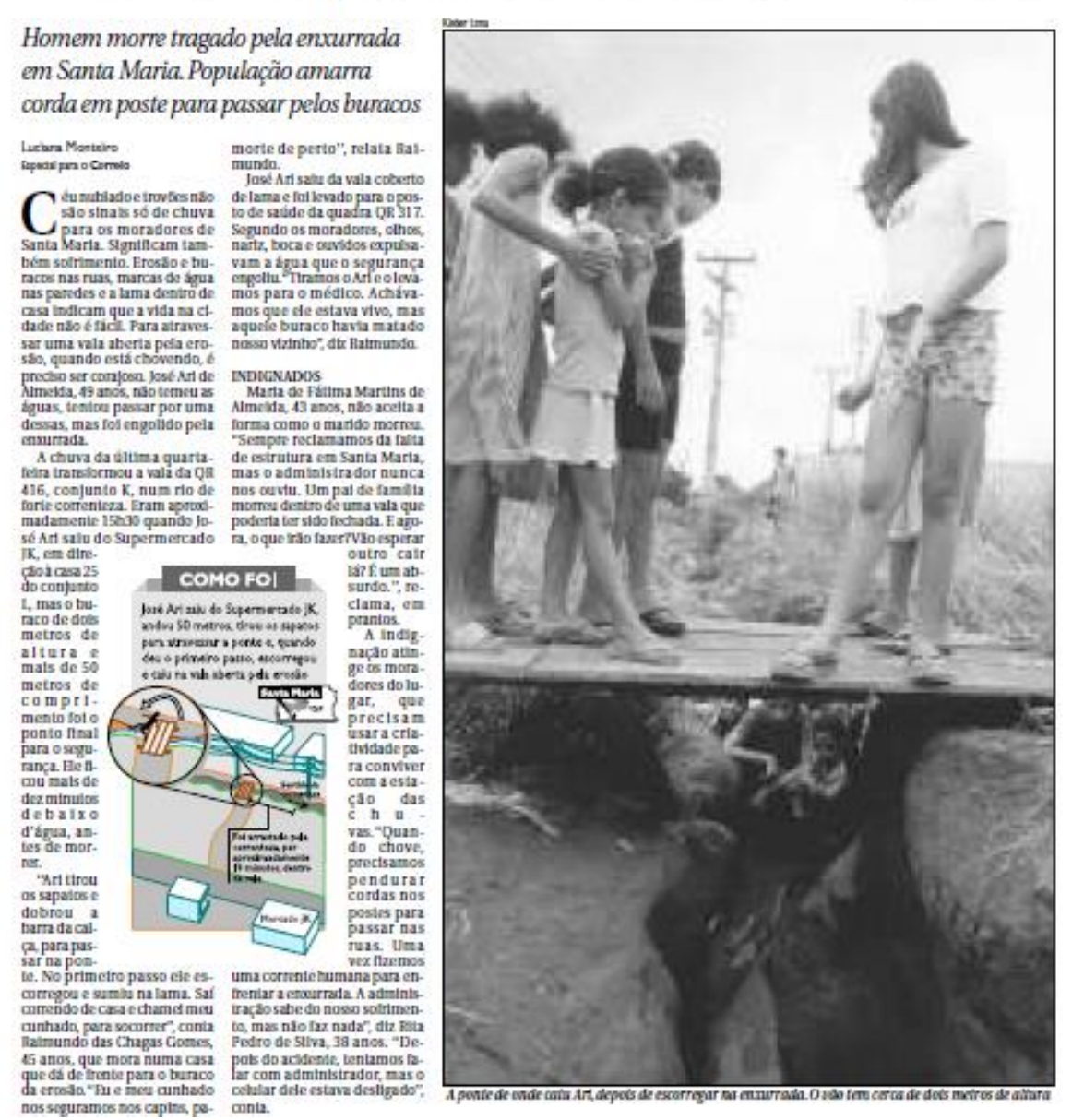

Figura 11. Recorte de reportagem de fevereiro de 2000 (Apêndice I, Notícia no 5). Fonte: Correio Braziliense.

\subsubsection{Ano de 2001}

O ano de 2001 foi um ano que seguiu a tendência da Normal Climatológica, ficando abaixo das médias mensais, o que caracteriza um ano pouco chuvoso. A Estação Brasília do INMET registrou um total de precipitação acumulada anualmente de 1285,5 mm de chuva (Gráfico 13), aproximadamente 16\% abaixo da média de precipitação anual da Normal Climatológica e na Estação Roncador do INMET, 1160,6 mm, cerca de 24,7\% abaixo da Normal, que é de 1540,6 mm (Gráfico 14).

No período chuvoso, de novembro a abril, os gráficos de precipitação acumulada mensalmente mostram que em janeiro e fevereiro os valores ficaram abaixo da Normal, superando a média no mês de março. Em abril, mês 
que caracteriza o fim da estação chuvosa e início da estação seca, as chuvas foram irregulares, superando a média na Estação Brasília e ficando abaixo da média na Estação Roncador. Em agosto as chuvas superaram a Normal, iniciando o período chuvoso começou mais cedo, e mesmo seguindo a tendência da Normal, as médias de setembro a dezembro permaneceram abaixo da média.

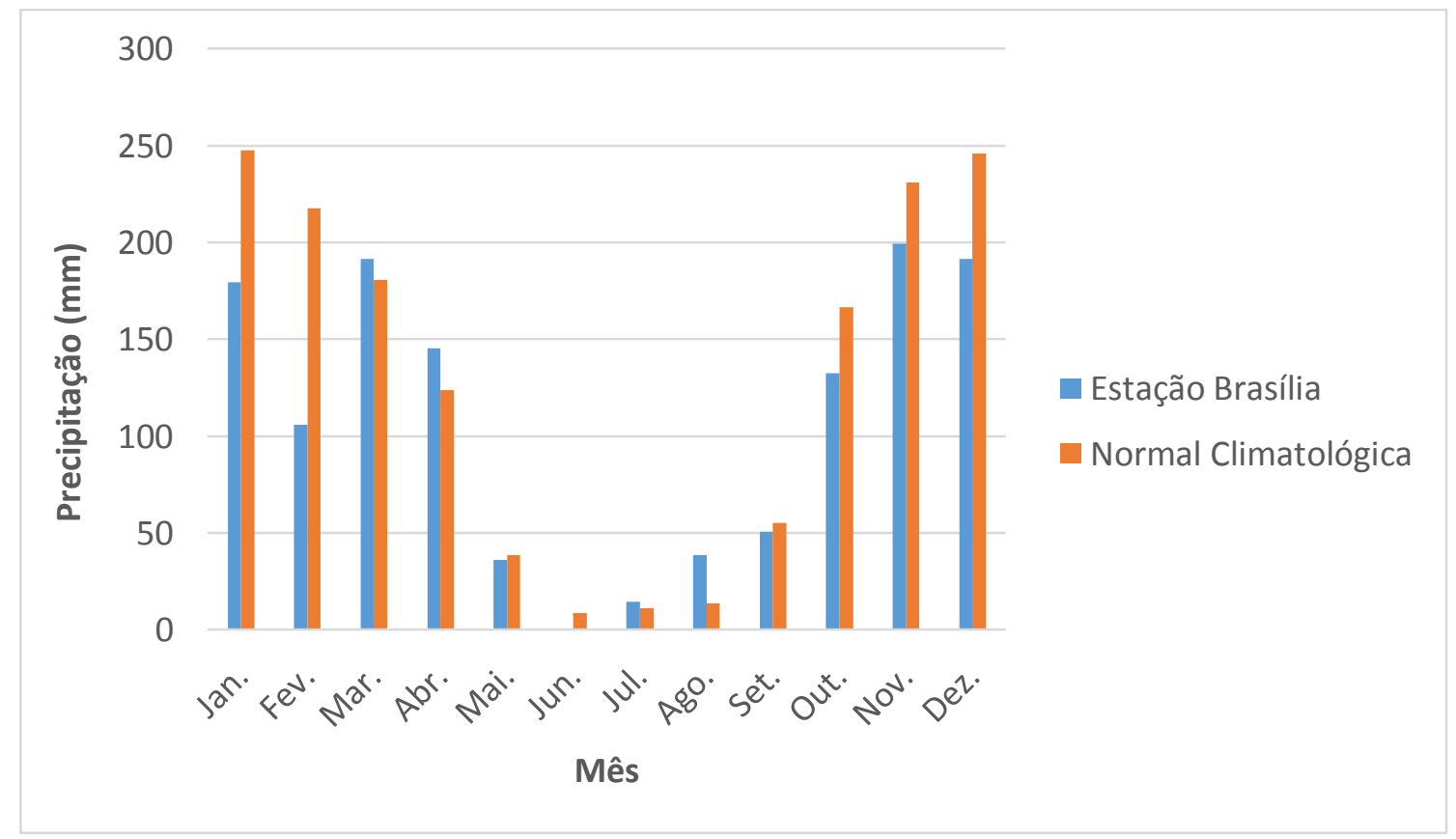

Gráfico 13. Precipitação mensal acumulada em 2001 na Estação Brasília do INMET (DF).

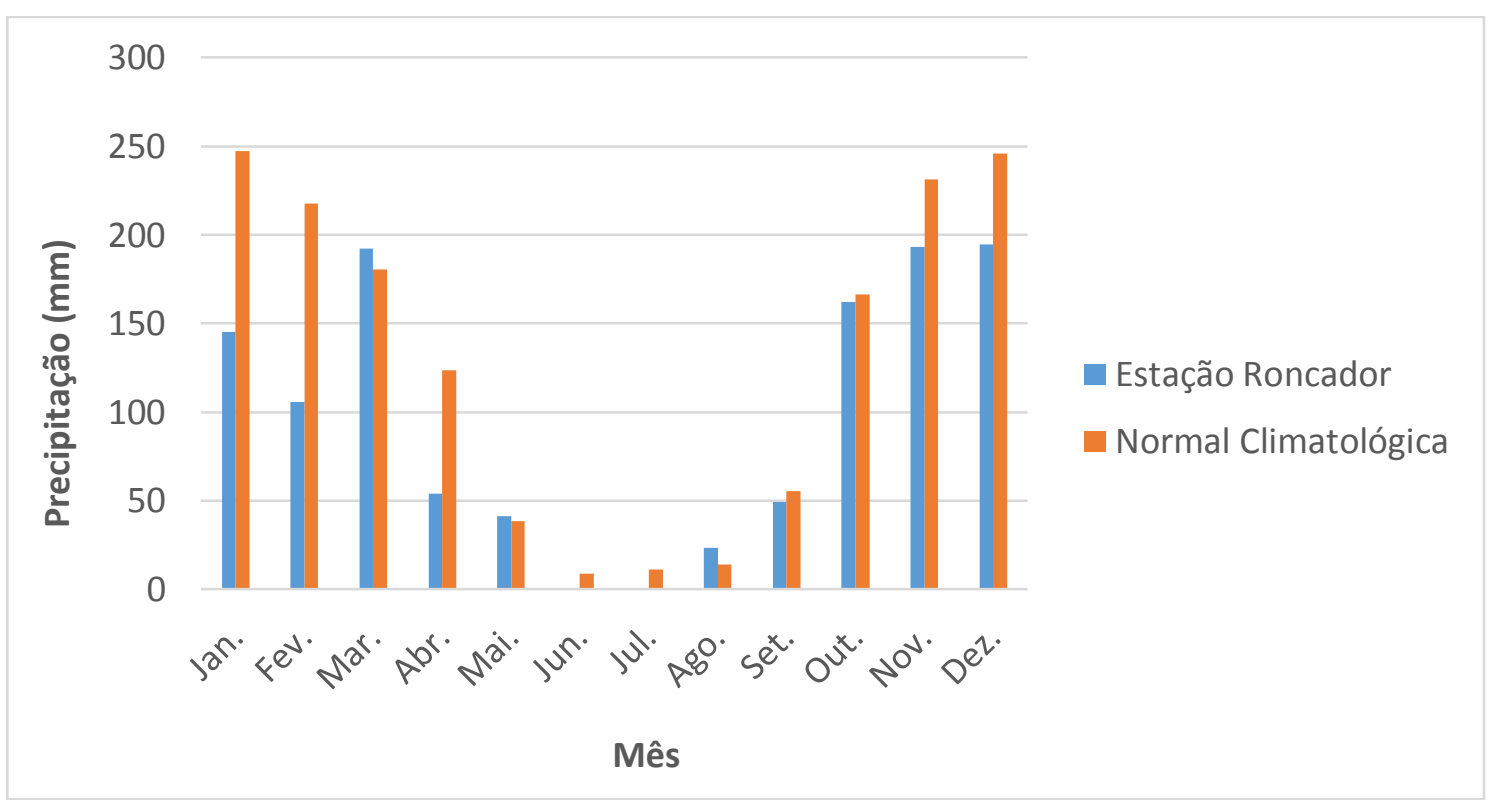

Gráfico 14. Precipitação mensal acumulada em 2001 na Estação Roncador do INMET (DF). 
Em 2001 foram encontradas 6 reportagens referentes à desastres naturais associados às precipitações, observando-se que a maior quantidade de notícias se deu nos meses de janeiro e março, com 2 reportagens cada com 3 reportagens, como pode ser aferido no Gráfico 15 e no Apêndice II.

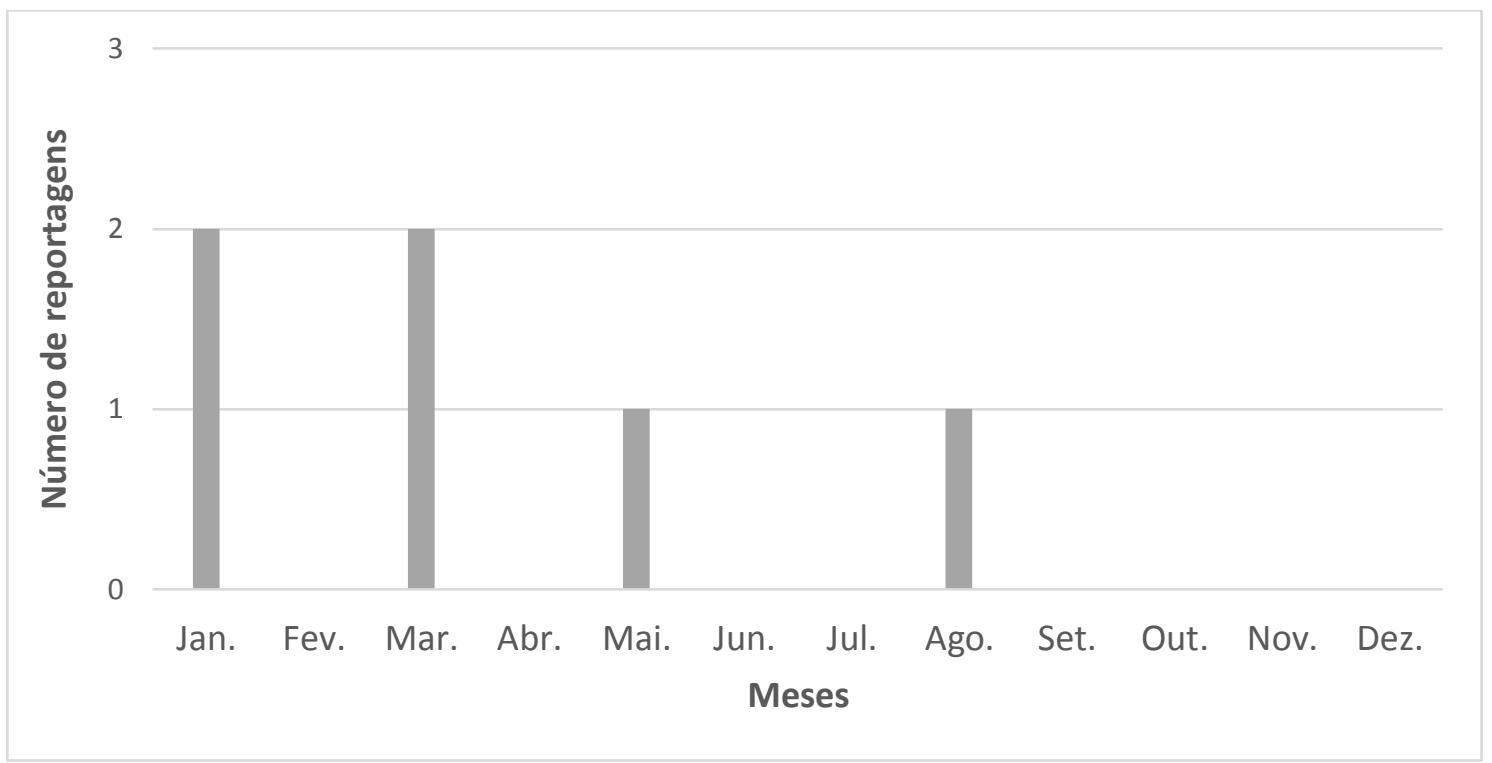

Gráfico 15. Número de reportagens encontradas mensalmente em 2001. Fonte dos dados: Correio Braziliense. Elaborado pelo autor.

De acordo com o que foi registrado nas reportagens, as Regiões Administrativas mais afetadas foram Brasília (RA I) e Santa Maria (RA XIII), com 3 ocorrências de desastres. Completam o Quadro 3 as RA's do Guará (RA $X)$ e Cruzeiro (RA XI), que tiveram uma ocorrência de desastre cada.

\begin{tabular}{|c|c|c|c|c|c|c|c|}
\hline $\begin{array}{c}\text { Região } \\
\text { Administrativa }\end{array}$ & Alagamento & Enxurrada & Erosão & Granizo & $\begin{array}{c}\text { Movimento } \\
\text { de Massa }\end{array}$ & Vendaval & Total \\
\hline Plano Piloto (RA I) & 2 & 0 & 0 & 0 & 0 & 1 & 3 \\
\hline Gama (RA II) & 0 & 0 & 0 & 0 & 0 & 0 & 0 \\
\hline $\begin{array}{l}\text { Taguatinga (RA } \\
\text { III) }\end{array}$ & 0 & 0 & 0 & 0 & 0 & 0 & 0 \\
\hline Brazlândia (RA IV) & 0 & 0 & 0 & 0 & 0 & 0 & 0 \\
\hline Sobradinho (RA V) & 0 & 0 & 0 & 0 & 0 & 0 & 0 \\
\hline Planaltina (RA VI) & 0 & 0 & 0 & 0 & 0 & 0 & 0 \\
\hline Paranoá (RA VII) & 0 & 0 & 0 & 0 & 0 & 0 & 0 \\
\hline $\begin{array}{l}\text { Núcleo } \\
\text { Bandeirante (RA } \\
\text { VIII) }\end{array}$ & 0 & 0 & 0 & 0 & 0 & 0 & 0 \\
\hline Ceilândia (RA IX) & 0 & 0 & 0 & 0 & 0 & 0 & 0 \\
\hline Guará (RA X) & 1 & 0 & 0 & 0 & 0 & 0 & 1 \\
\hline Cruzeiro (RA XI) & 1 & 0 & 0 & 0 & 0 & 0 & 1 \\
\hline $\begin{array}{l}\text { Samambaia (RA } \\
\text { XII) }\end{array}$ & 0 & 0 & 0 & 0 & 0 & 0 & 0 \\
\hline
\end{tabular}




\begin{tabular}{|c|c|c|c|c|c|c|c|}
\hline $\begin{array}{l}\text { Santa Maria (RA } \\
\text { XIII) }\end{array}$ & 0 & 1 & 2 & 0 & 0 & 0 & 3 \\
\hline $\begin{array}{l}\text { São Sebastião (RA } \\
\text { XIV) }\end{array}$ & 0 & 0 & 0 & 0 & 0 & 0 & 0 \\
\hline $\begin{array}{l}\text { Recanto das Emas } \\
\text { (RA XV) }\end{array}$ & 0 & 0 & 0 & 0 & 0 & 0 & 0 \\
\hline Lago Sul (RA XVI) & 0 & 0 & 0 & 0 & 0 & 0 & 0 \\
\hline $\begin{array}{l}\text { Riacho Fundo (RA } \\
\text { XVII) }\end{array}$ & 0 & 0 & 0 & 0 & 0 & 0 & 0 \\
\hline $\begin{array}{l}\text { Lago Norte (RA } \\
\text { XVIII) }\end{array}$ & 0 & 0 & 0 & 0 & 0 & 0 & 0 \\
\hline $\begin{array}{l}\text { Candangolândia } \\
\text { (RA XIX) }\end{array}$ & 0 & 0 & 0 & 0 & 0 & 0 & 0 \\
\hline $\begin{array}{l}\text { Águas Claras (RA } \\
\text { XX) }\end{array}$ & 0 & 0 & 0 & 0 & 0 & 0 & 0 \\
\hline $\begin{array}{l}\text { Riacho Fundo II } \\
\text { (RA XXI) }\end{array}$ & 0 & 0 & 0 & 0 & 0 & 0 & 0 \\
\hline $\begin{array}{l}\text { Sudoeste / } \\
\text { Octogonal (RA } \\
\text { XXII) }\end{array}$ & 0 & 0 & 0 & 0 & 0 & 0 & 0 \\
\hline Varjão (RA XXIII) & 0 & 0 & 0 & 0 & 0 & 0 & 0 \\
\hline $\begin{array}{l}\text { Park Way (RA } \\
\text { XXIV) }\end{array}$ & 0 & 0 & 0 & 0 & 0 & 0 & 0 \\
\hline $\begin{array}{l}\text { Setor } \\
\text { Complementar de } \\
\text { Indústria e } \\
\text { Abastecimento } \\
\text { (RA XXV) }\end{array}$ & 0 & 0 & 0 & 0 & 0 & 0 & 0 \\
\hline $\begin{array}{l}\text { Sobradinho II (RA } \\
\text { XXVI) }\end{array}$ & 0 & 0 & 0 & 0 & 0 & 0 & 0 \\
\hline $\begin{array}{l}\text { Jardim Botânico } \\
\text { (RA XXVII) }\end{array}$ & 0 & 0 & 0 & 0 & 0 & 0 & 0 \\
\hline Itapoã (RA XXVII) & 0 & 0 & 0 & 0 & 0 & 0 & 0 \\
\hline $\begin{array}{l}\text { Setor de Indústria } \\
\text { e Abastecimento } \\
\text { (RA XXIX) }\end{array}$ & 0 & 0 & 0 & 0 & 0 & 0 & 0 \\
\hline $\begin{array}{l}\text { Vicente Pires (RA } \\
\text { XXX) }\end{array}$ & 0 & 0 & 0 & 0 & 0 & 0 & 0 \\
\hline Fercal (RA XXXI) & 0 & 0 & 0 & 0 & 0 & 0 & 0 \\
\hline Total & 4 & 1 & 2 & 0 & 0 & 1 & 8 \\
\hline
\end{tabular}

Quadro 3. Número de reportagens encontradas mensalmente em 2001 com tipologia de desastres naturais. Elaborado pelo autor.

Em relação à tipologia de desastres naturais, os alagamentos foram os desastres naturais que ocorreram com maior frequência, sendo observados 4 vezes nas Regiões Administrativas; seguidos por erosões, com 2 ocorrências; enxurradas e vendavais, com uma ocorrência cada. As porcentagens de cada tipo de desastres podem ser observadas no Gráfico 16. 


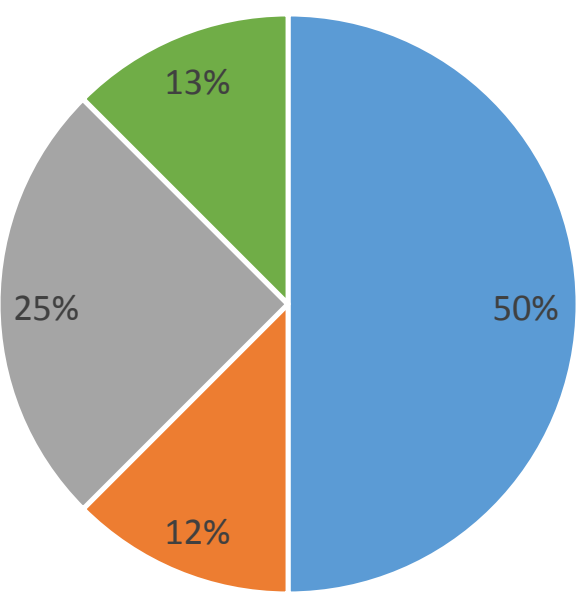

- Alagamento

- Enxurrada

- Erosão

- Vendaval

Gráfico 16. Porcentagem de desastres naturais encontrados nas reportagens ocorridos em 2001. Elaborado pelo autor.

No ano de 2001, destacam-se duas reportagens, ambas referentes à criação e urbanização da Região Administrativa de Santa Maria (RA XIII). Na primeira, a enxurrada carrega o cascalho que a Administração de Santa Maria põe para tapar erosão que fica no meio da rua no Conjunto "A" da quadra 402. A RA ainda não apresentava infraestrutura de coleta de águas pluviais, o que preocupou os moradores que afirmavam que a força das enxurradas era capaz de levar pessoas.

A segunda reportagem aponta para um problema que afetava a cidade vizinha à Santa Maria, Novo Gama, no estado de Goiás. A ocupação da RA reduziu o volume da lâmina d'água de um ribeirão por causa de lixo e de erosões. Os areais às margens do ribeirão Santa Maria, somados às chuvas entupiram o sistema de abastecimento e distribuição de água na cidade vizinha, o que afetou mais de 50 mil pessoas. 


\section{SANTA MARIA \\ Erosão destrói ruas e põe moradores em risco}

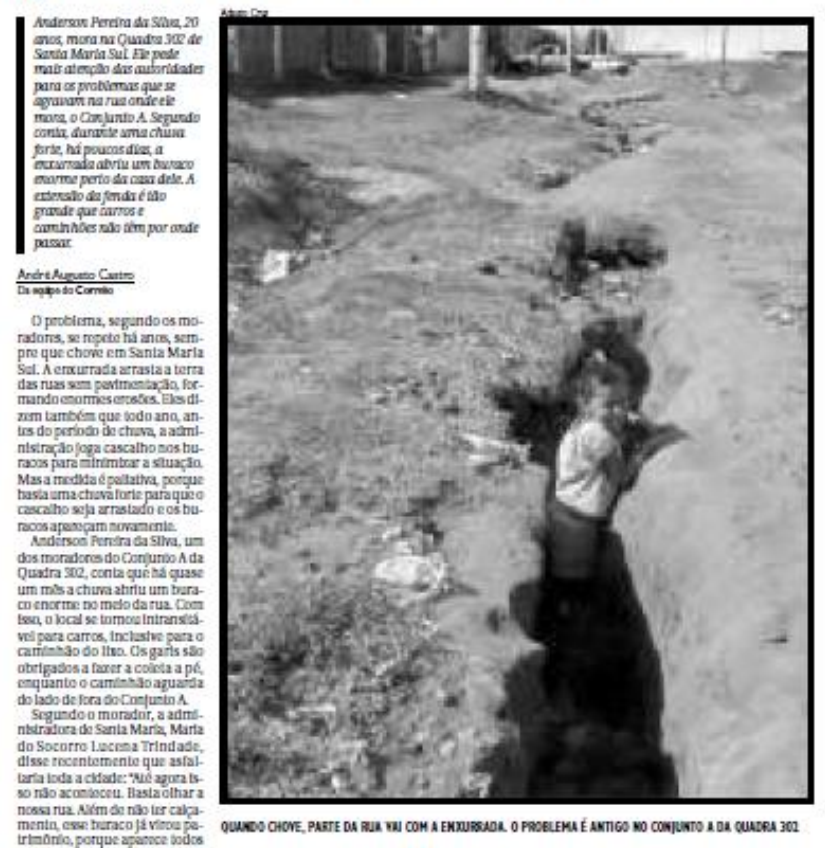

Figura 12. Recorte de reportagem de janeiro de 2001 (Apêndice II, Notícia no 2). Fonte: Correio Braziliense.

$$
\begin{aligned}
& \text { Movo GamA } \\
& \text { Criação de Santa Maria, no DF, reduziu o volume e encheu de lixo o ribeirão que } \\
& \text { abastece a cidade vizinha. Com as chuvas, } 50 \text { mil moradores estão sem água }
\end{aligned}
$$

\section{Estado de emergência}

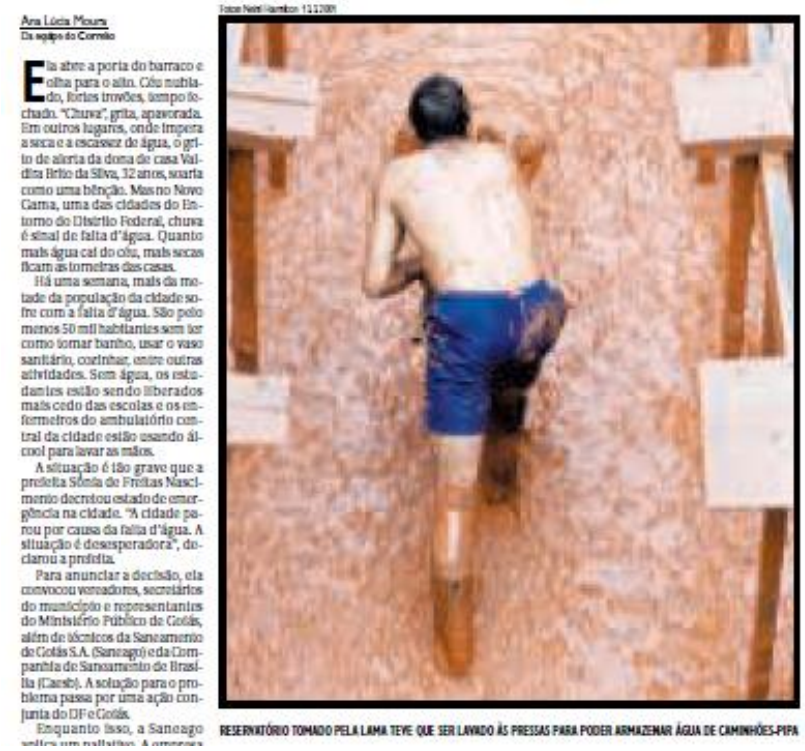

Figura 13. Recorte de reportagem de março de 2001 (Apêndice II, Notícia no 4). Fonte: Correio Braziliense. 


\subsubsection{Ano de 2002}

O ano de 2002 seguiu a tendência da Normal Climatológica, mas ficou abaixo das médias mensais, ou seja, foi um ano pouco chuvoso. A Estação Brasília do INMET registrou um total de precipitação acumulada anualmente de 1389,5 mm de chuva (Gráfico 17), aproximadamente 10\% abaixo da média de precipitação anual da Normal Climatológica e na Estação Roncador do INMET, $1154,9 \mathrm{~mm}$, cerca de 25\% abaixo da Normal, que é de 1540,6 mm (Gráfico 18).

No período chuvoso, de novembro a abril, os gráficos de precipitação acumulada mensalmente mostram que entre janeiro e abril os valores ficaram abaixo da média, exceto pelo mês de fevereiro que na Estação Brasília foi ligeiramente superior à Normal Climatológica. Em setembro, mês caracterizado pelas chuvas irregulares devido à retomada da estação chuvosa, houve chuvas acima da média, porém em outubro elas ficaram aquém do esperado para 0 mês. Em novembro e dezembro as chuvas foram irregulares, sendo que novembro foi abaixo a média na Estação Brasília de novembro e superou a média na Estação Roncador. $O$ inverso ocorreu em dezembro, quando a precipitação registrada na Estação Brasília foi acima da média e na Estação Roncador as chuvas superaram a Normal.

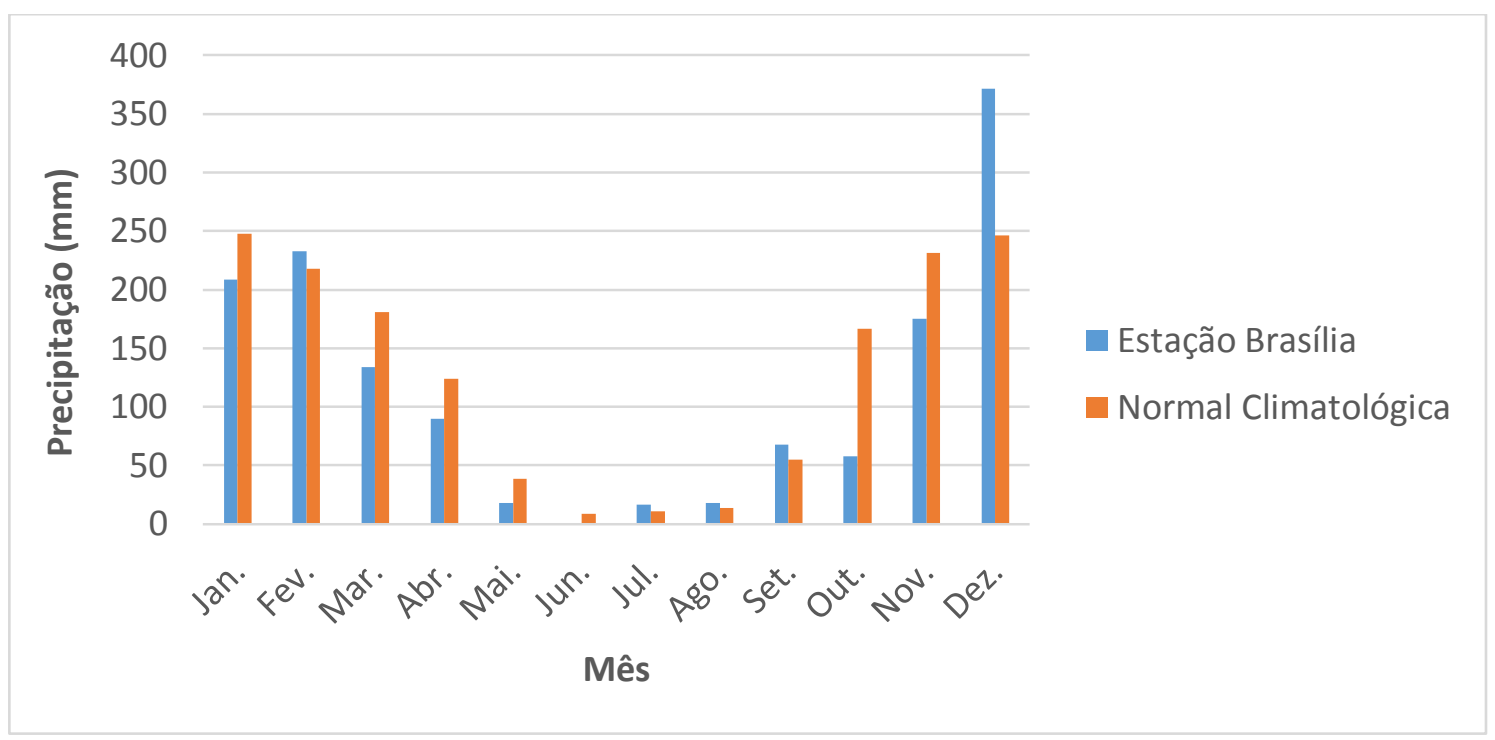

Gráfico 17. Precipitação mensal acumulada em 2002 na Estação Brasília do INMET (DF). 


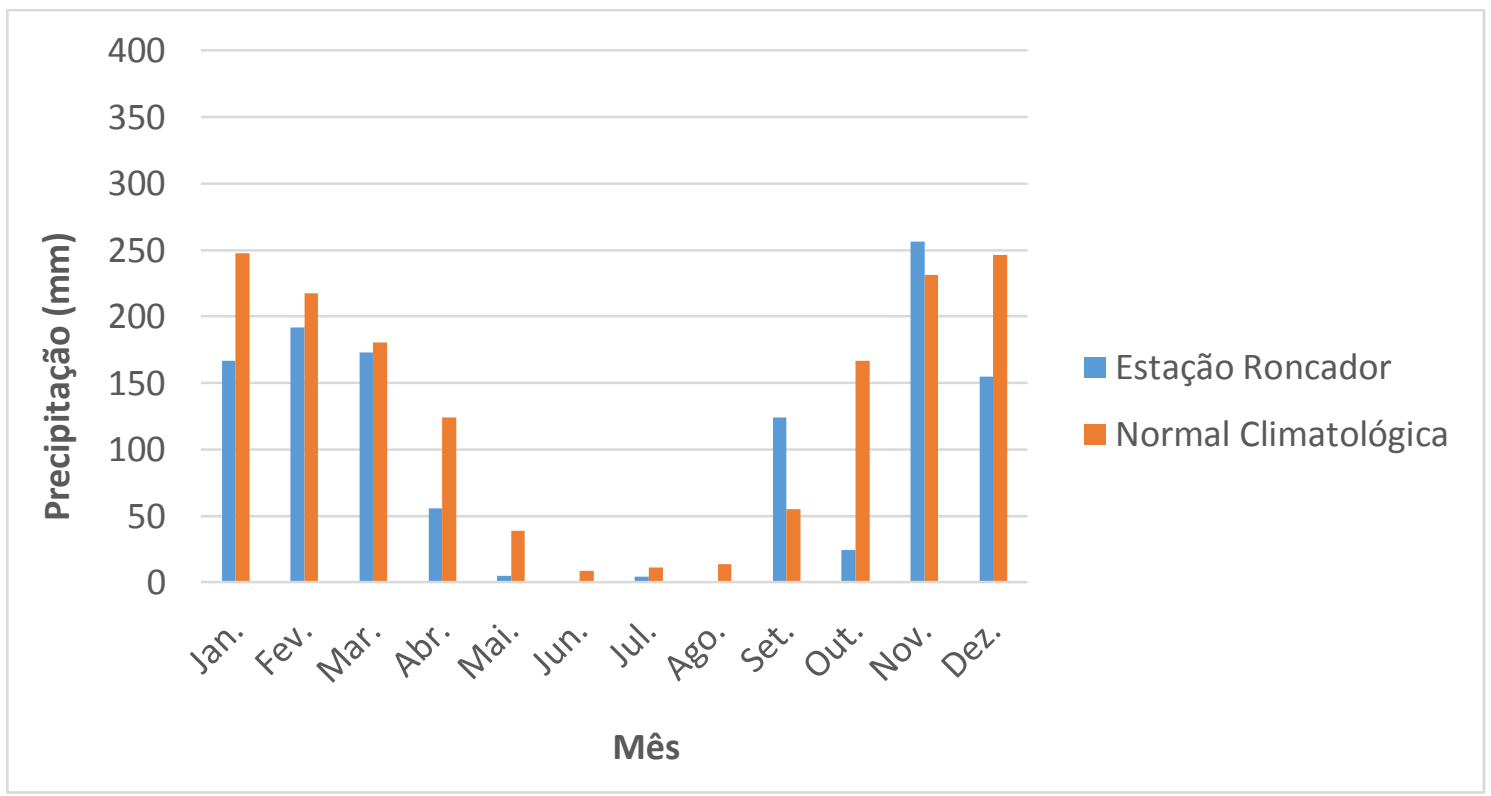

Gráfico 18. Precipitação mensal acumulada em 2002 na Estação Roncador do INMET (DF).

Em 2002 foram encontradas 6 reportagens referentes à desastres naturais associados às precipitações, observando-se que a maior quantidade de notícias se deu no mês de dezembro, com 2 reportagens, como pode ser aferido no Gráfico 19 e no Apêndice III.

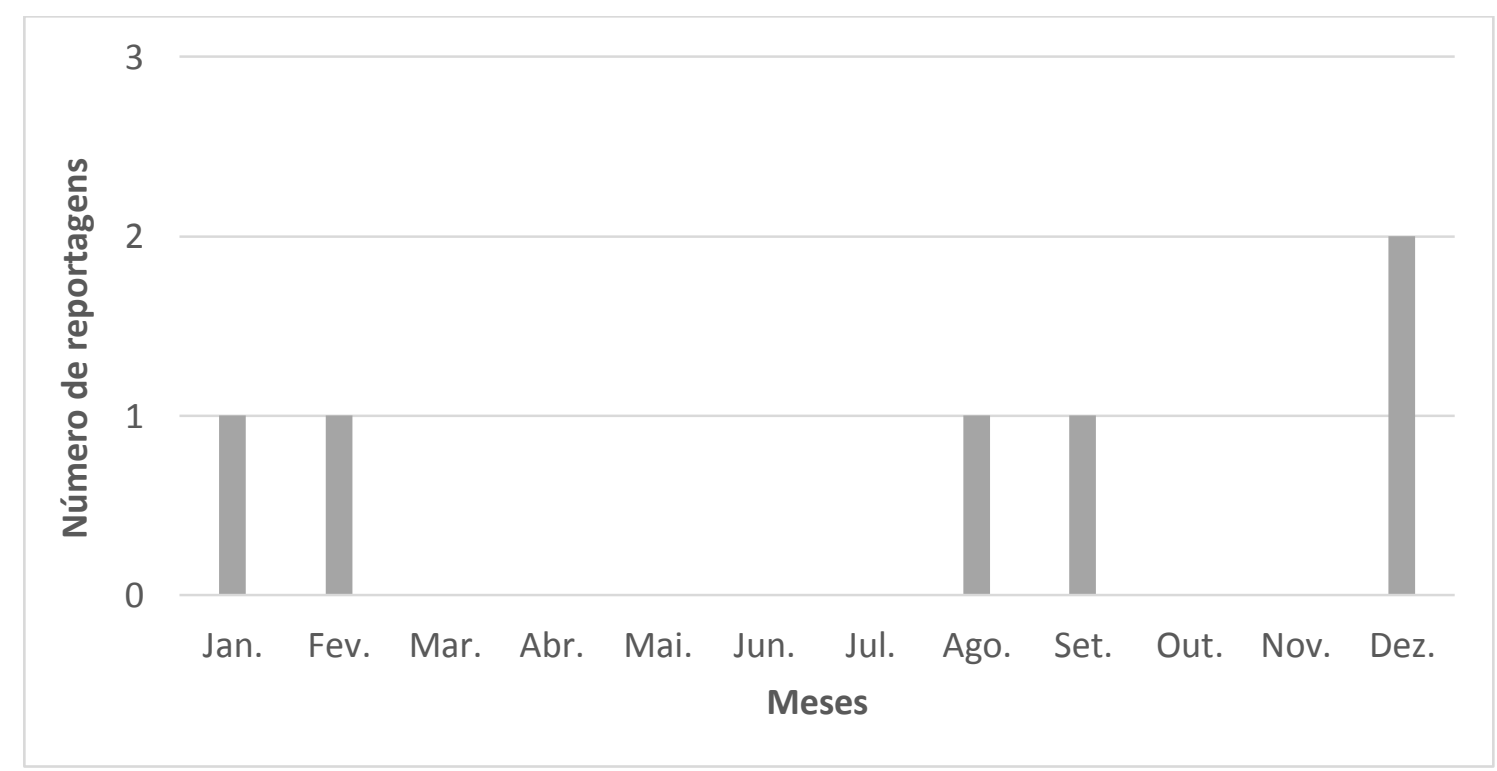

Gráfico 19. Número de reportagens encontradas mensalmente em 2002. Fonte dos dados: Correio Braziliense. Elaborado pelo autor.

De acordo com o que foi registrado nas reportagens, a Região Administrativa mais afetada foi o Riacho Fundo (RA XVII), com 5 ocorrências 
de desastres (Quadro 4). Taguatinga (RA III), Ceilândia (RA XI), Guará (RA X) e Samambaia (RA XII) tiveram 3 ocorrências de desastre cada.

\begin{tabular}{|c|c|c|c|c|c|c|c|}
\hline $\begin{array}{l}\text { Região } \\
\text { Administrativa }\end{array}$ & Alagamento & Enxurrada & Erosão & Granizo & $\begin{array}{c}\text { Movimento } \\
\text { de Massa }\end{array}$ & Vendaval & Total \\
\hline $\begin{array}{l}\text { Plano Piloto } \\
\text { (RA I) }\end{array}$ & 1 & 0 & 0 & 1 & 0 & 0 & 2 \\
\hline Gama (RA II) & 0 & 0 & 0 & 0 & 0 & 0 & 0 \\
\hline $\begin{array}{l}\text { Taguatinga } \\
\text { (RA III) }\end{array}$ & 1 & 0 & 0 & 1 & 0 & 1 & 3 \\
\hline $\begin{array}{l}\text { Brazlândia (RA } \\
\text { IV) }\end{array}$ & 0 & 0 & 0 & 1 & 0 & 0 & 1 \\
\hline $\begin{array}{l}\text { Sobradinho } \\
\text { (RA V) }\end{array}$ & 0 & 0 & 0 & 0 & 0 & 0 & 0 \\
\hline $\begin{array}{l}\text { Planaltina (RA } \\
\text { VI) }\end{array}$ & 0 & 0 & 0 & 0 & 0 & 0 & 0 \\
\hline $\begin{array}{l}\text { Paranoá (RA } \\
\text { VII) }\end{array}$ & 0 & 0 & 0 & 0 & 0 & 0 & 0 \\
\hline \multicolumn{8}{|l|}{ Núcleo } \\
\hline $\begin{array}{l}\text { Bandeirante } \\
\text { (RA VIII) }\end{array}$ & 0 & 0 & 0 & 0 & 0 & 0 & 0 \\
\hline $\begin{array}{l}\text { Ceilândia (RA } \\
\text { IX) }\end{array}$ & 1 & 0 & 0 & 1 & 0 & 1 & 3 \\
\hline Guará (RA X) & 2 & 1 & 0 & 0 & 0 & 0 & 3 \\
\hline $\begin{array}{l}\text { Cruzeiro (RA } \\
\mathrm{XI})\end{array}$ & 0 & 0 & 0 & 0 & 0 & 0 & 0 \\
\hline $\begin{array}{l}\text { Samambaia } \\
\text { (RA XII) }\end{array}$ & 1 & 1 & 0 & 1 & 0 & 0 & 3 \\
\hline $\begin{array}{l}\text { Santa Maria } \\
\text { (RA XIII) }\end{array}$ & 1 & 1 & 0 & 0 & 0 & 0 & 2 \\
\hline $\begin{array}{l}\text { São Sebastião } \\
\text { (RA XIV) }\end{array}$ & 1 & 1 & 0 & 0 & 0 & 0 & 2 \\
\hline $\begin{array}{l}\text { Recanto das } \\
\text { Emas (RA XV) }\end{array}$ & 1 & 1 & 0 & 0 & 0 & 0 & 2 \\
\hline $\begin{array}{l}\text { Lago Sul (RA } \\
\text { XVI) }\end{array}$ & 0 & 0 & 0 & 0 & 0 & 0 & 0 \\
\hline $\begin{array}{l}\text { Riacho Fundo } \\
\text { (RA XVII) }\end{array}$ & 2 & 1 & 0 & 1 & 0 & 1 & 5 \\
\hline $\begin{array}{l}\text { Lago Norte } \\
\text { (RA XVIII) }\end{array}$ & 0 & 0 & 0 & 0 & 0 & 0 & 0 \\
\hline $\begin{array}{l}\text { Candangolând } \\
\text { ia (RA XIX) }\end{array}$ & 0 & 0 & 0 & 0 & 0 & 0 & 0 \\
\hline $\begin{array}{l}\text { Águas Claras } \\
\text { (RA XX) }\end{array}$ & 0 & 0 & 0 & 0 & 0 & 0 & 0 \\
\hline $\begin{array}{l}\text { Riacho Fundo } \\
\text { II (RA XXI) }\end{array}$ & 0 & 0 & 0 & 0 & 0 & 0 & 0 \\
\hline Sudoeste / & & & & & & & \\
\hline $\begin{array}{l}\text { Octogonal (RA } \\
\text { XXII) }\end{array}$ & 0 & 0 & 0 & 0 & 0 & 0 & 0 \\
\hline $\begin{array}{l}\text { Varjão (RA } \\
\text { XXIII) }\end{array}$ & 0 & 0 & 0 & 0 & 0 & 0 & 0 \\
\hline $\begin{array}{l}\text { Park Way (RA } \\
\text { XXIV) }\end{array}$ & 0 & 0 & 0 & 0 & 0 & 0 & 0 \\
\hline $\begin{array}{l}\text { Setor } \\
\text { Complementa }\end{array}$ & 0 & 0 & 0 & 0 & 0 & 0 & 0 \\
\hline
\end{tabular}




\begin{tabular}{|c|c|c|c|c|c|c|c|}
\hline $\begin{array}{l}\text { r de Indústria } \\
\text { e } \\
\text { Abasteciment } \\
\text { o (RA XXV) }\end{array}$ & & & & & & & \\
\hline $\begin{array}{l}\text { Sobradinho II } \\
\text { (RA XXVI) }\end{array}$ & 0 & 0 & 0 & 0 & 0 & 0 & 0 \\
\hline Jardim & & & & & & & \\
\hline $\begin{array}{l}\text { Botânico (RA } \\
\text { XXVII) }\end{array}$ & 0 & 0 & 0 & 0 & 0 & 0 & 0 \\
\hline $\begin{array}{l}\text { Itapoã (RA } \\
\text { XXVII) }\end{array}$ & 0 & 0 & 0 & 0 & 0 & 0 & 0 \\
\hline $\begin{array}{l}\text { Setor de } \\
\text { Indústria e } \\
\text { Abasteciment } \\
\text { o (RA XXIX) }\end{array}$ & 1 & 0 & 0 & 0 & 0 & 0 & 1 \\
\hline $\begin{array}{l}\text { Vicente Pires } \\
\text { (RA XXX) }\end{array}$ & 0 & 0 & 0 & 0 & 0 & 0 & 0 \\
\hline $\begin{array}{l}\text { Fercal (RA } \\
\text { XXXI) }\end{array}$ & 0 & 0 & 0 & 0 & 0 & 0 & 0 \\
\hline Total & 12 & 6 & 0 & 6 & 0 & 3 & 27 \\
\hline
\end{tabular}

Quadro 4. Número de reportagens encontradas mensalmente em 2002 com tipologia de desastres naturais. Elaborado pelo autor.

Em relação à tipologia de desastres naturais, os alagamentos foram os desastres naturais que ocorreram com maior frequência, sendo observados 12 vezes nas Regiões Administrativas; seguidos por enxurradas e queda de granizo, com 6 ocorrências; e vendavais, com 3 ocorrências. As porcentagens de cada tipo de desastres podem ser observadas no Gráfico 20.

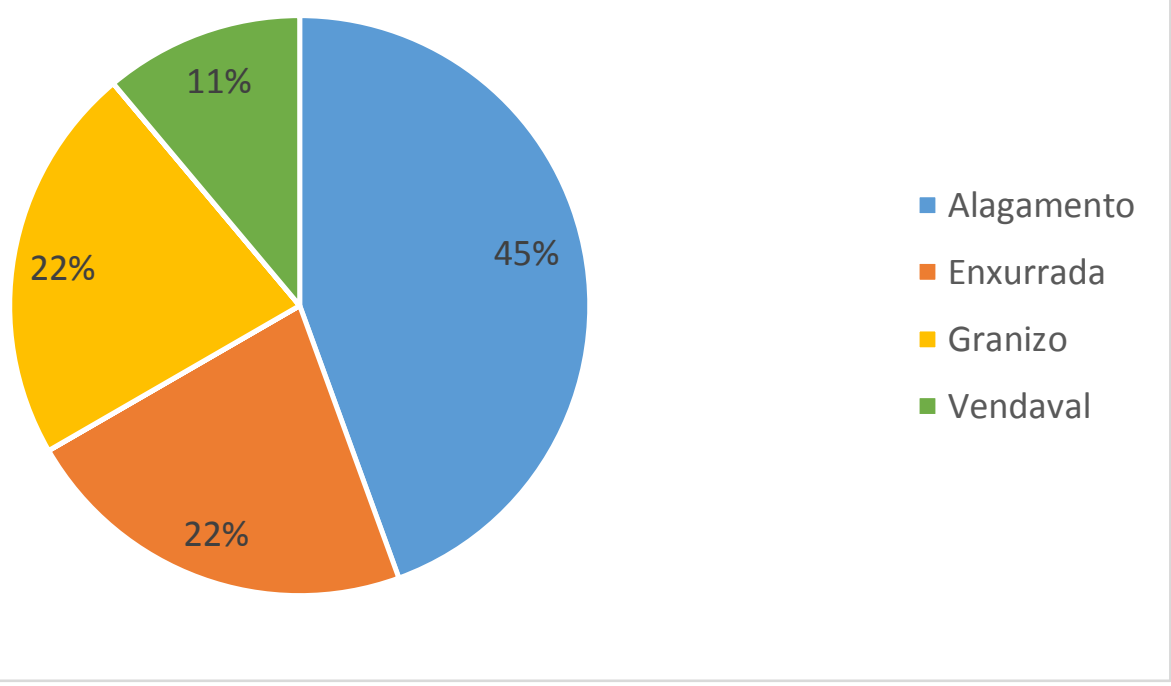

Gráfico 20. Porcentagem de desastres naturais encontrados nas reportagens ocorridos em 2002. Elaborado pelo autor.

Dentre as notícias de 2002, destaca-se a do dia 31 de dezembro. De acordo com a reportagem, a chuva mais forte do ano ocorreu no dia 29, 
quando foi registrado pelo INMET 94,8 mm de precipitação. Vários pontos do DF ficaram alagados, dentre os quais: o recém-inaugurado acesso da via L4 para a Ponte JK, lojas na Asa Sul e Norte e a Feira dos Importados. Em algumas áreas, o nível d'água chegou a ficar com $50 \mathrm{~cm}$ de altura.

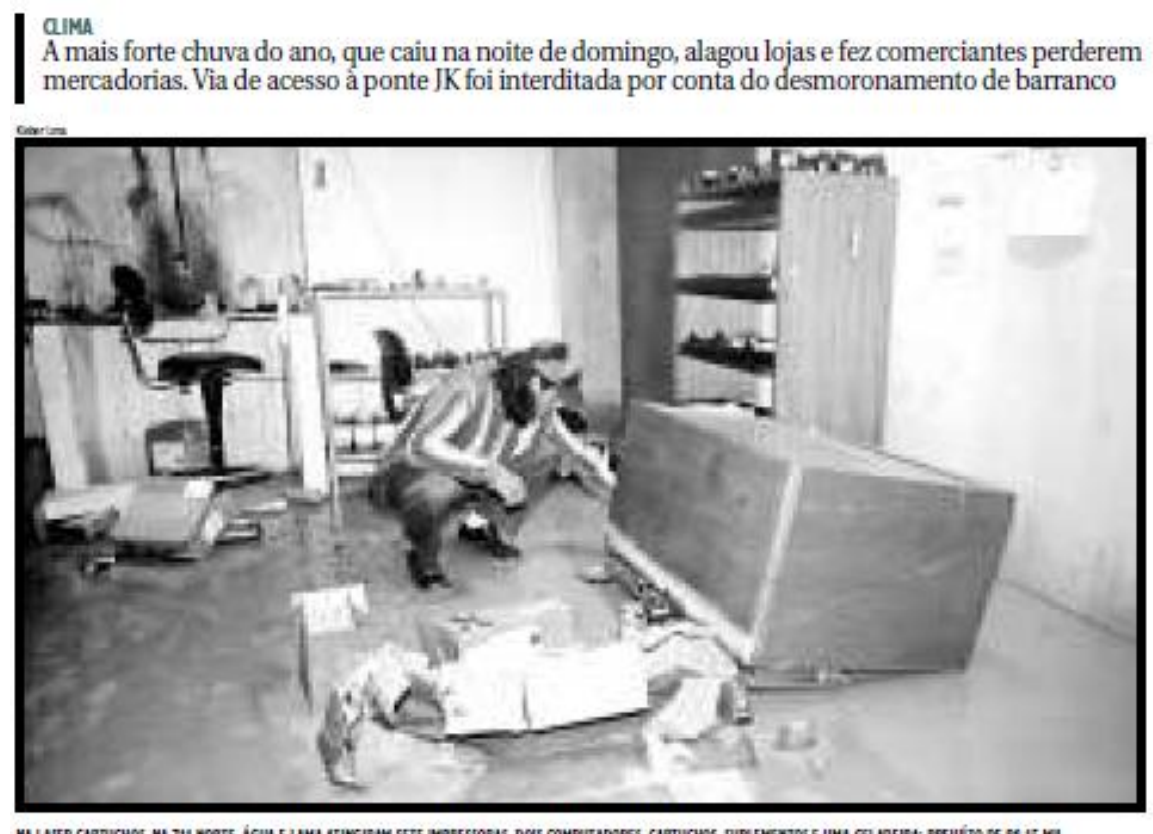

\section{Dia de contabilizar os prejuízos}

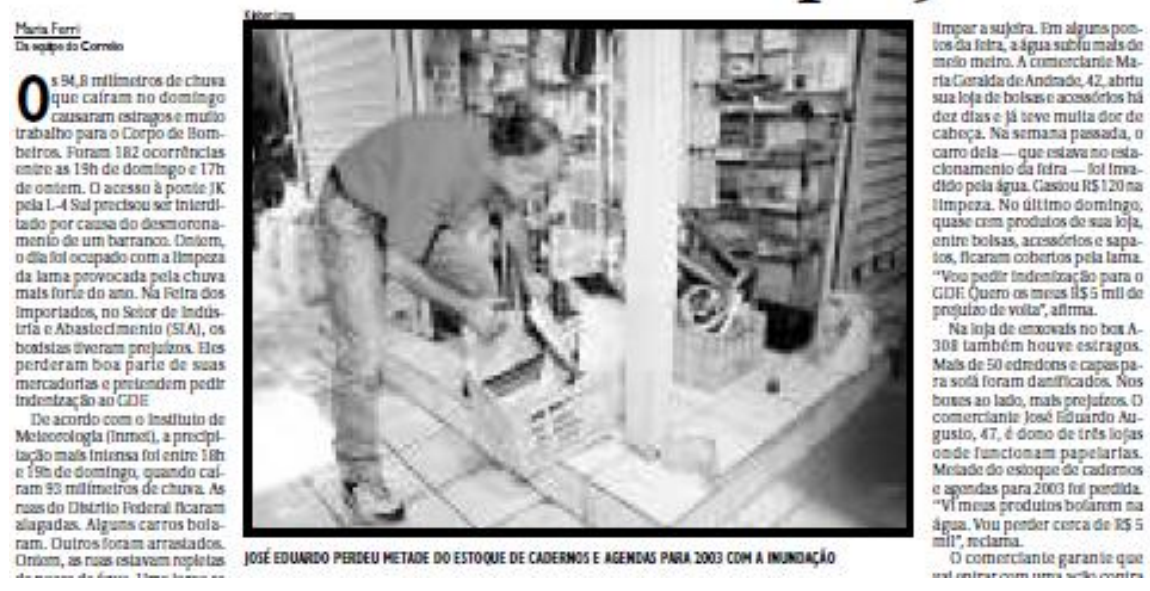

Figura 14. Recorte de reportagem de dezembro de 2002 (Apêndice III, Notícia ํㅜ 6). Fonte: Correio Braziliense. 


\subsubsection{Ano de 2003}

O ano de 2003 foi um ano pouco chuvoso. A Estação Brasília do INMET registrou um total de precipitação acumulada anualmente de 1287,2 $\mathrm{mm}$ de chuva (Gráfico 21), aproximadamente 17\% abaixo da média de precipitação anual da Normal Climatológica e a Estação Roncador do INMET registrou 1095,1 mm, cerca de 29\% abaixo da Normal, que é de 1540,6 mm (Gráfico 22).

No período chuvoso, de novembro a abril, observamos dois comportamentos distintos na área urbana (Estação Brasília) e na área preservada (Estação Roncador). Os gráficos de precipitação da Estação Brasília que em janeiro, fevereiro e abril os valores ficaram abaixo da média, superando a média apenas em março. Na Estação Roncador, as médias foram superadas em janeiro e março, e ficaram abaixo do esperado em fevereiro e abril. À exceção do mês de novembro, entre agosto e dezembro ambas as estações tiveram comportamentos semelhantes, com chuvas acima da média em agosto e abaixo da média setembro, outubro e dezembro.

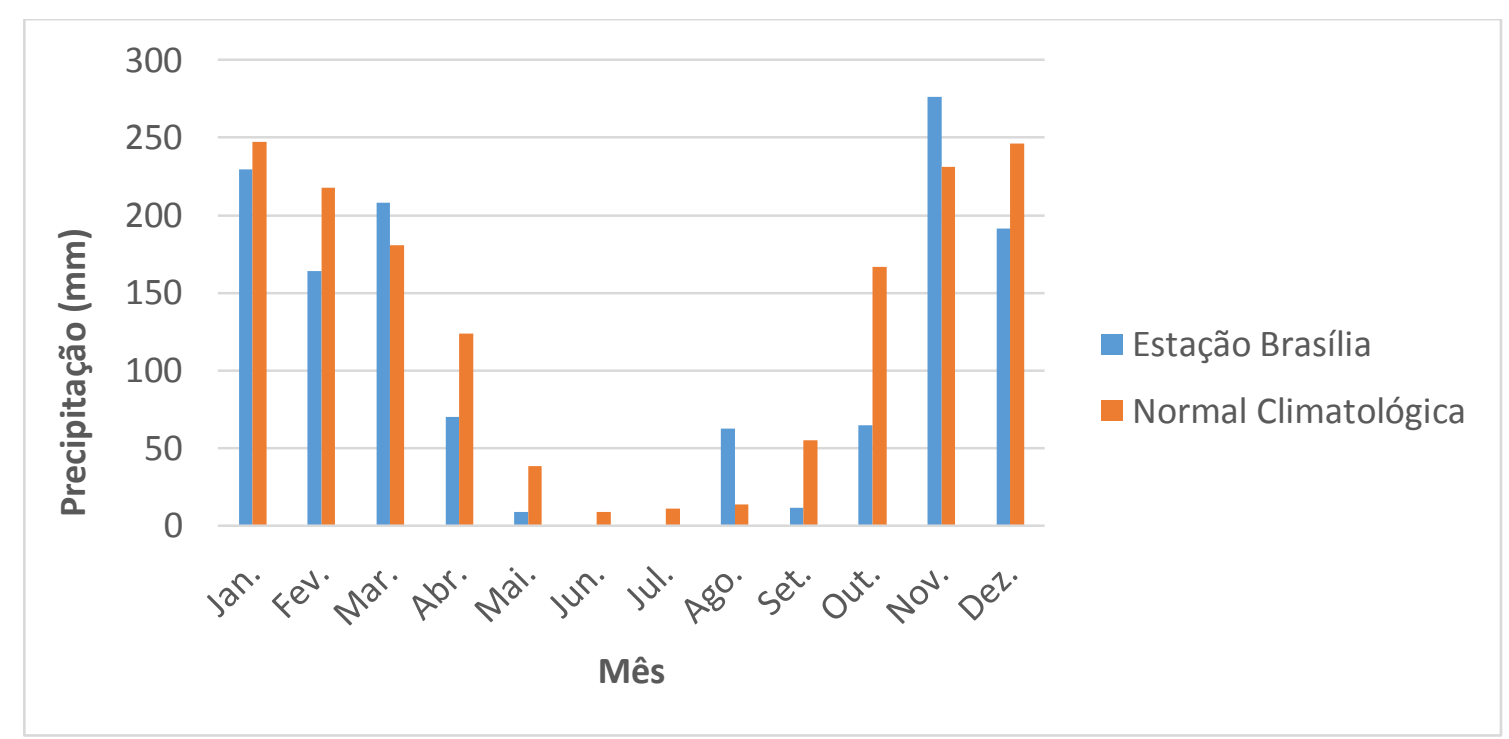

Gráfico 21. Precipitação mensal acumulada em 2003 na Estação Brasília do INMET (DF). 


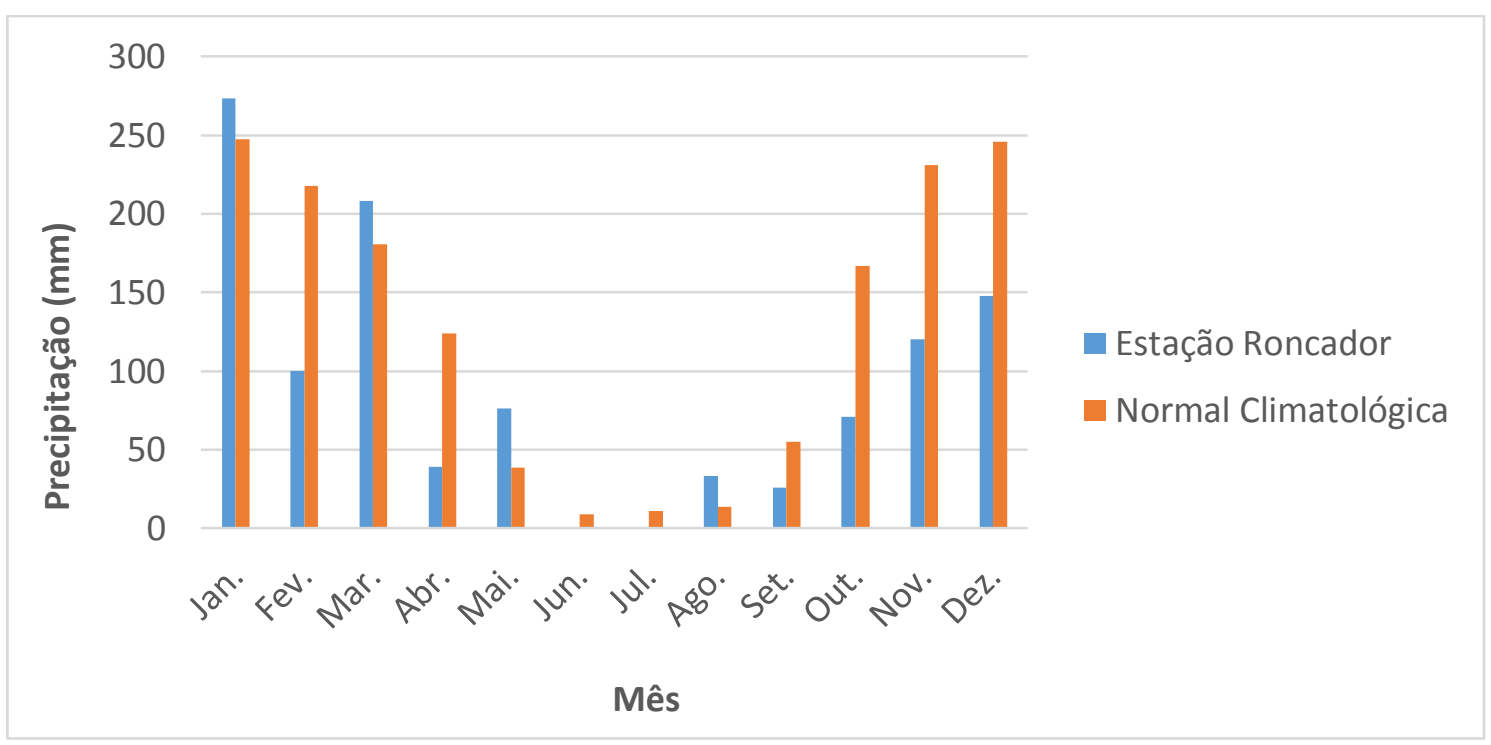

Gráfico 22. Precipitação mensal acumulada em 2003 na Estação Roncador do INMET (DF).

Mesmo com um volume de chuvas abaixo da média, mas de valores razoáveis, em 2003 foram encontradas apenas 2 reportagens referentes à desastres naturais associados às precipitações, nos meses de janeiro e dezembro respectivamente, como pode ser aferido no Gráfico 23 e no Apêndice IV.

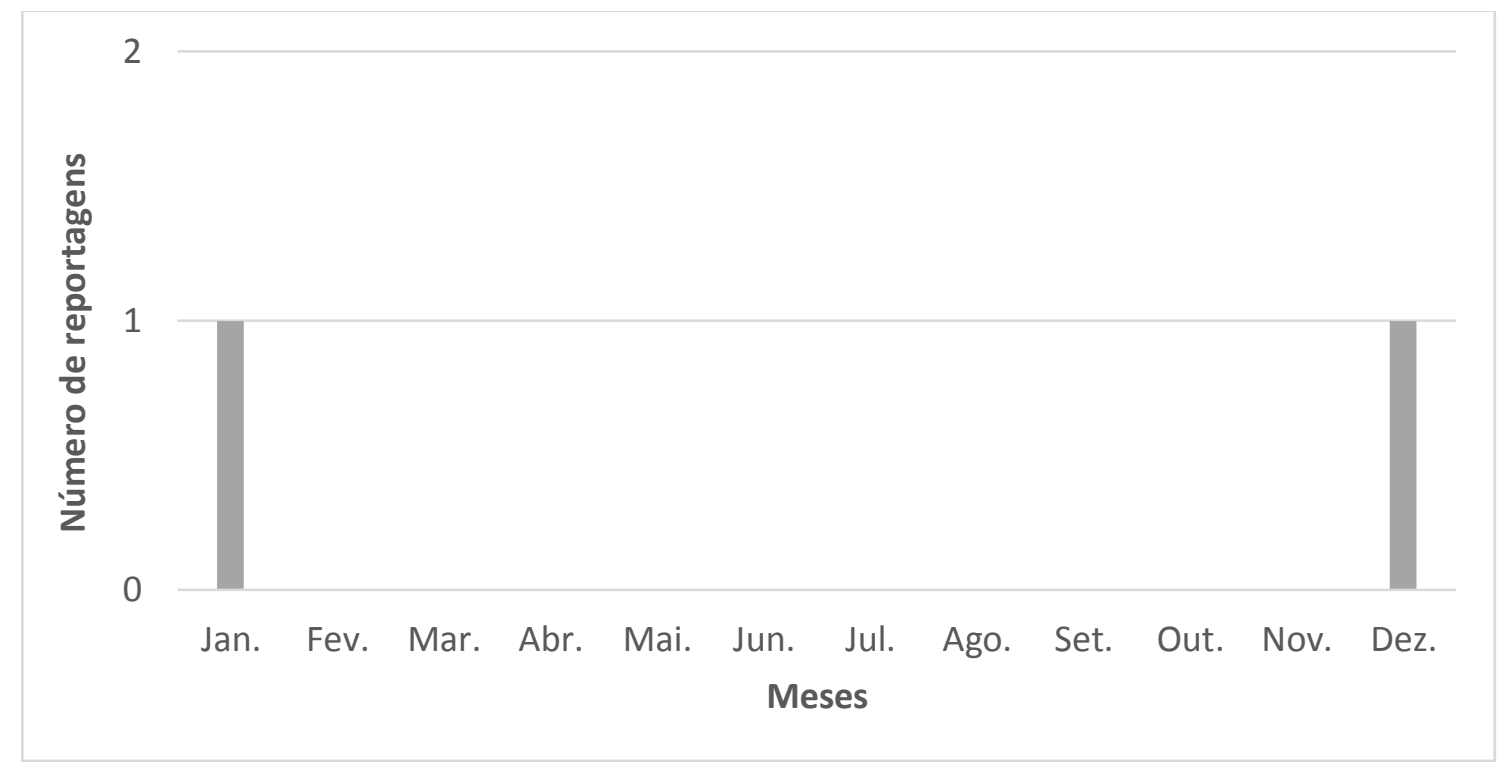

Gráfico 23. Número de reportagens encontradas mensalmente em 2003. Fonte dos dados: Correio Braziliense. Elaborado pelo autor.

De acordo com o que foi registrado nas reportagens, as Regiões Administrativas mais afetadas foram Recanto das Emas (RA XV) e o Jardim Botânico (RA XXVII), com 3 ocorrências de desastres cada (Quadro 5). Santa 
Maria (RA XIII), com 2 ocorrências, e o Guará (RA X), com uma ocorrência de desastres, completam o quadro.

\begin{tabular}{|c|c|c|c|c|c|c|c|}
\hline $\begin{array}{l}\text { Região } \\
\text { Administrativa }\end{array}$ & Alagamento & Enxurrada & Erosão & Granizo & $\begin{array}{l}\text { Movimento } \\
\text { de Massa }\end{array}$ & Vendaval & Total \\
\hline $\begin{array}{l}\text { Plano Piloto (RA } \\
\text { I) }\end{array}$ & 0 & 0 & 0 & 0 & 0 & 0 & 0 \\
\hline Gama (RA II) & 0 & 0 & 0 & 0 & 0 & 0 & 0 \\
\hline $\begin{array}{l}\text { Taguatinga (RA } \\
\text { III) }\end{array}$ & 0 & 0 & 0 & 0 & 0 & 0 & 0 \\
\hline $\begin{array}{l}\text { Brazlândia (RA } \\
\text { IV) }\end{array}$ & 0 & 0 & 0 & 0 & 0 & 0 & 0 \\
\hline $\begin{array}{l}\text { Sobradinho (RA } \\
\text { V) }\end{array}$ & 0 & 0 & 0 & 0 & 0 & 0 & 0 \\
\hline Planaltina (RA VI) & 0 & 0 & 0 & 0 & 0 & 0 & 0 \\
\hline Paranoá (RA VII) & 0 & 0 & 0 & 0 & 0 & 0 & 0 \\
\hline $\begin{array}{l}\text { Núcleo } \\
\text { Bandeirante (RA } \\
\text { VIII) }\end{array}$ & 0 & 0 & 0 & 0 & 0 & 0 & 0 \\
\hline Ceilândia (RA IX) & 0 & 0 & 0 & 0 & 0 & 0 & 0 \\
\hline Guará (RA X) & 0 & 0 & 0 & 0 & 0 & 1 & 1 \\
\hline Cruzeiro (RA XI) & 0 & 0 & 0 & 0 & 0 & 0 & 0 \\
\hline $\begin{array}{l}\text { Samambaia (RA } \\
\text { XII) }\end{array}$ & 0 & 0 & 0 & 0 & 0 & 0 & 0 \\
\hline $\begin{array}{l}\text { Santa Maria (RA } \\
\text { XIII) }\end{array}$ & 1 & 0 & 0 & 0 & 0 & 1 & 2 \\
\hline $\begin{array}{l}\text { São Sebastião } \\
\text { (RA XIV) }\end{array}$ & 0 & 0 & 0 & 0 & 0 & 0 & 0 \\
\hline $\begin{array}{l}\text { Recanto das } \\
\text { Emas (RA XV) }\end{array}$ & 1 & 1 & 0 & 0 & 0 & 1 & 3 \\
\hline Lago Sul (RA XVI) & 0 & 0 & 0 & 0 & 0 & 0 & 0 \\
\hline $\begin{array}{l}\text { Riacho Fundo (RA } \\
\text { XVII) }\end{array}$ & 0 & 0 & 0 & 0 & 0 & 0 & 0 \\
\hline $\begin{array}{l}\text { Lago Norte (RA } \\
\text { XVIII) }\end{array}$ & 0 & 0 & 0 & 0 & 0 & 0 & 0 \\
\hline $\begin{array}{l}\text { Candangolândia } \\
\text { (RA XIX) }\end{array}$ & 0 & 0 & 0 & 0 & 0 & 0 & 0 \\
\hline $\begin{array}{l}\text { Águas Claras (RA } \\
\mathrm{XX} \text { ) }\end{array}$ & 0 & 0 & 0 & 0 & 0 & 0 & 0 \\
\hline $\begin{array}{l}\text { Riacho Fundo II } \\
\text { (RA XXI) }\end{array}$ & 0 & 0 & 0 & 0 & 0 & 0 & 0 \\
\hline $\begin{array}{l}\text { Sudoeste / } \\
\text { Octogonal (RA } \\
\text { XXII) }\end{array}$ & 0 & 0 & 0 & 0 & 0 & 0 & 0 \\
\hline Varjão (RA XXIII) & 0 & 0 & 0 & 0 & 0 & 0 & 0 \\
\hline $\begin{array}{l}\text { Park Way (RA } \\
\text { XXIV) }\end{array}$ & 0 & 0 & 0 & 0 & 0 & 0 & 0 \\
\hline $\begin{array}{l}\text { Setor } \\
\text { Complementar } \\
\text { de Indústria e } \\
\text { Abastecimento } \\
\text { (RA XXV) }\end{array}$ & 0 & 0 & 0 & 0 & 0 & 0 & 0 \\
\hline $\begin{array}{l}\text { Sobradinho II (RA } \\
\text { XXVI) }\end{array}$ & 0 & 0 & 0 & 0 & 0 & 0 & 0 \\
\hline
\end{tabular}




\begin{tabular}{|llllllll|}
\hline $\begin{array}{l}\text { Jardim Botânico } \\
\text { (RA XXVII) }\end{array}$ & 1 & 0 & 0 & 1 & 0 & 1 & 3 \\
Itapoã (RA XXVII) & 0 & 0 & 0 & 0 & 0 & 0 & 0 \\
$\begin{array}{l}\text { Setor de Indústria } \\
\text { e Abastecimento }\end{array}$ & 0 & 0 & 0 & 0 & 0 & 0 & 0 \\
$\begin{array}{l}\text { (RA XXIX) } \\
\text { Vicente Pires (RA }\end{array}$ & 0 & 0 & 0 & 0 & 0 & 0 & 0 \\
XXX) & 0 & 0 & 0 & 0 & 0 & 0 & 0 \\
Fercal (RA XXXI) & 0 & 1 & 0 & 1 & 0 & 4 & 9 \\
Total & 3 & & & & & & \\
\hline
\end{tabular}

Quadro 5. Número de reportagens encontradas mensalmente em 2003 com tipologia de desastres naturais. Elaborado pelo autor.

Em relação à tipologia de desastres naturais, os vendavais foram os desastres naturais que ocorreram com maior frequência, sendo observados 4 vezes nas Regiões Administrativas; seguidos por alagamentos, com 3 ocorrências; e enxurradas e queda de granizo, com uma ocorrência. As porcentagens de cada tipo de desastres podem ser observadas no Gráfico 24.

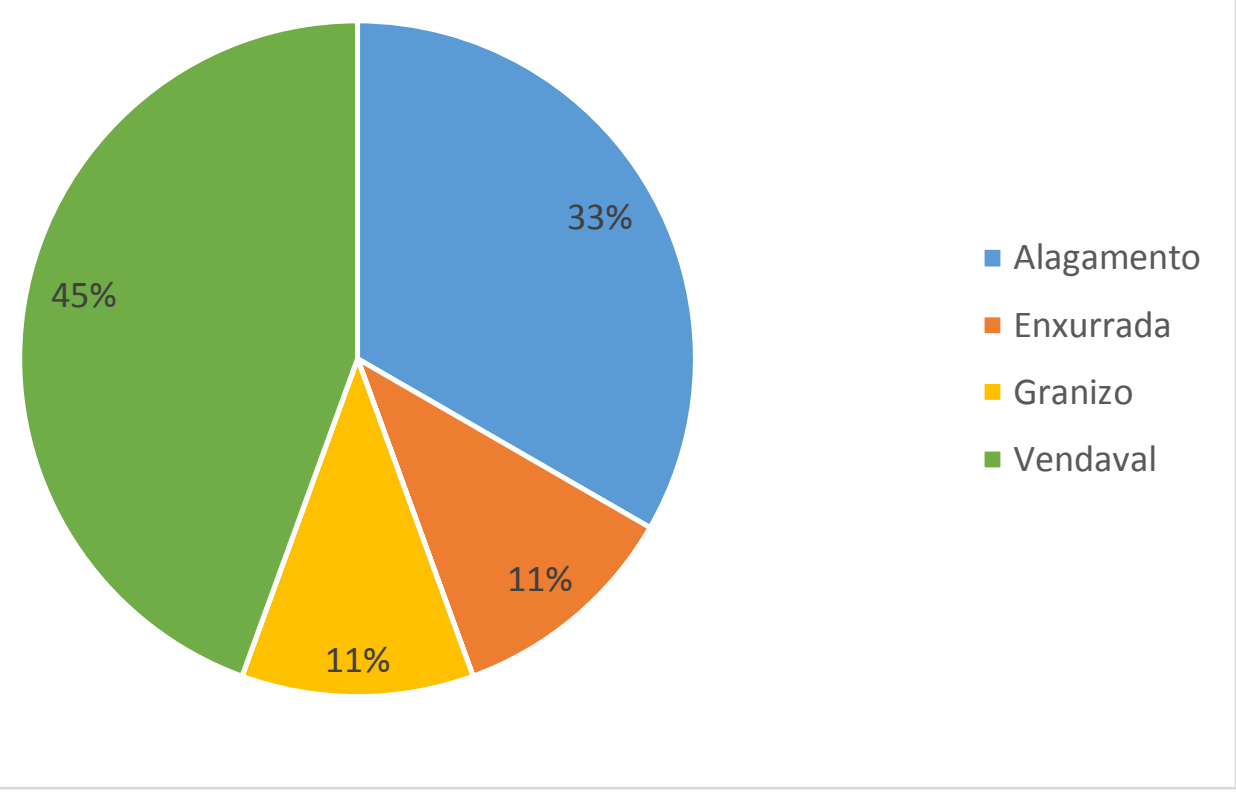

Gráfico 24. Porcentagem de desastres naturais encontrados nas reportagens ocorridos em 2003. Elaborado pelo autor.

Em 2003 destaca-se a reportagem do dia 2 de janeiro (Apêndice IV, Notícia $\mathrm{n}-1$ ), que mostra a ocorrência de desastres naturais em diversas localidades. Na Santa Maria, um vendaval acompanhado de chuva levantou o teto de ginásio recém-inaugurado, que tombou pela metade, e também arrancou telhados de casas. No Recanto das Emas, moradores também sofreram com destelhamentos em suas casas e relataram que fortes 
enxurradas que estavam carregando o asfalto das ruas. $O$ vento arrancou árvores pelas raízes e destruiu viveiros no Jardim Botânico o vento arrancou árvores pelas raízes e o granizo destruiu viveiros de plantas, causando danos de mais de 1 milhão de reais.

\subsubsection{Ano de 2004}

O ano de 2004 foi um ano típico, ou seja, apresentou características próximas da média, tendo registrado na Estação Brasília do INMET um total de precipitação acumulada anualmente de $1619 \mathrm{~mm}$ de chuva (Gráfico 25), aproximadamente $5 \%$ acima da média de precipitação anual da Normal Climatológica. A Estação Roncador do INMET registrou 1478,7 mm, cerca de $5 \%$ abaixo da Normal, que é de 1540,6 mm (Gráfico 26).

Os meses de janeiro a abril apresentaram precipitações intensas, superiores à Normal Climatológica. Destaca-se o mês de fevereiro, que em virtude de diversos episódios de ZCAS seguidos no Brasil (INMET, s. a.), levou a Estação Brasília a registrar incríveis $422,3 \mathrm{~mm}$ de precipitação, quase 0 dobro da média do mês, que é de $217,5 \mathrm{~mm}$. A estação seca nesse ano se prolongou, encerrando-se apenas em outubro, mês que é caracterizado pelas chuvas esparsas devido à transição da estação seca para a chuvosa, o que consequentemente ocasionou os resultados diferentes registrados na Estação Brasília e Roncador. Por sua vez, os meses de novembro e dezembro foram abaixo da média histórica. 


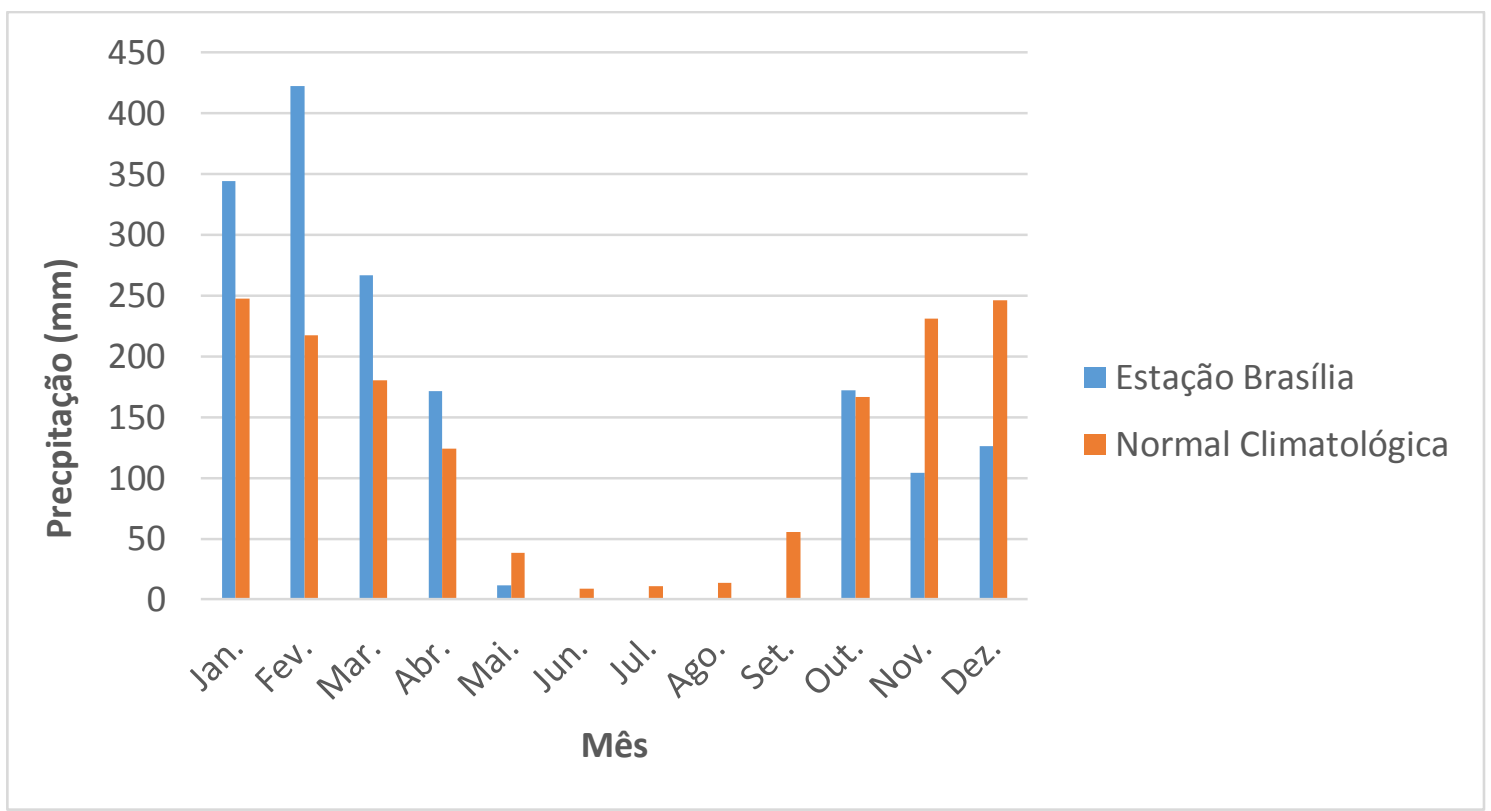

Gráfico 25. Precipitação mensal acumulada em 2004 na Estação Brasília do INMET (DF).

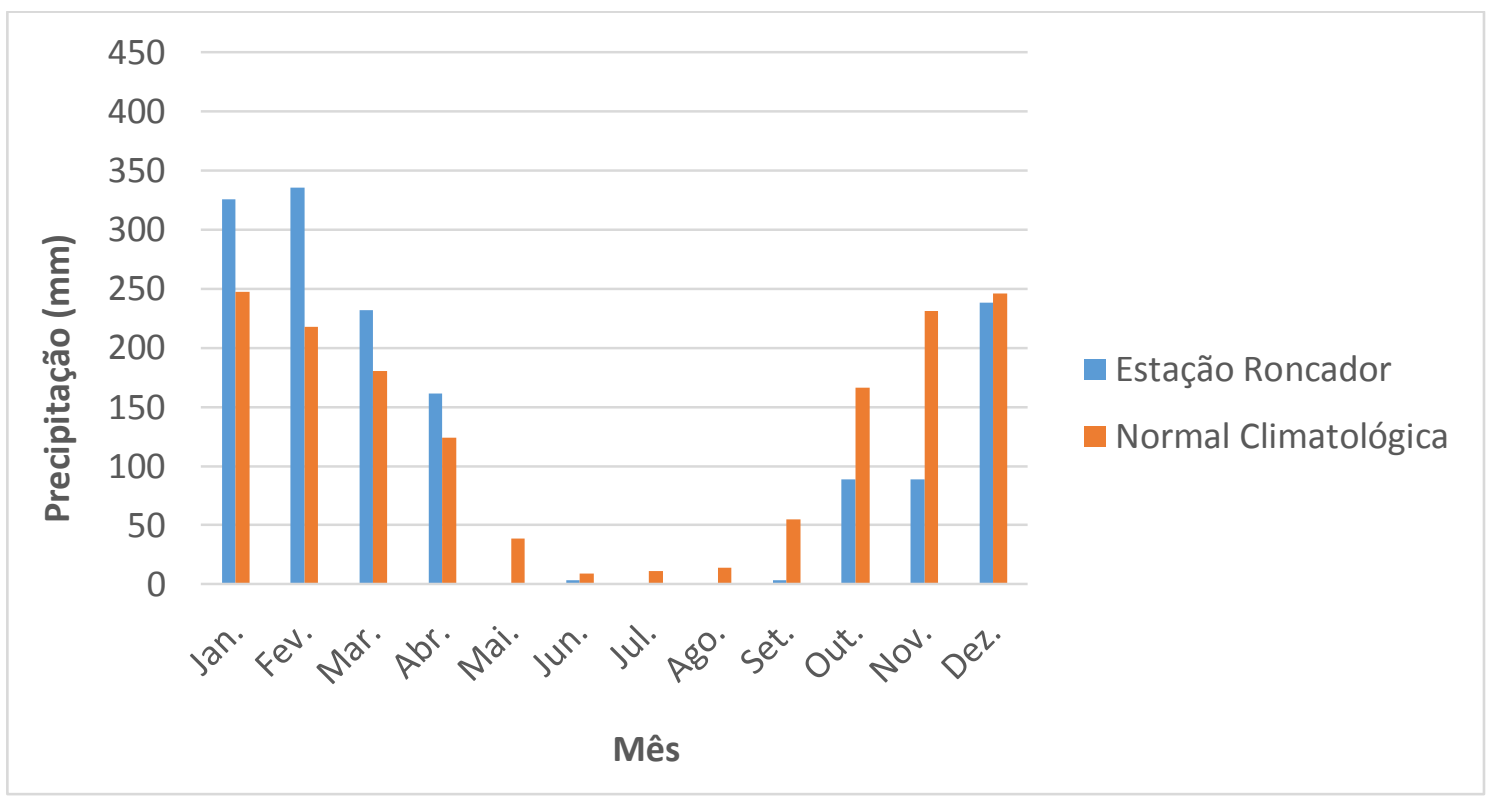

Gráfico 26. Precipitação mensal acumulada em 2004 na Estação Roncador do INMET (DF).

Em 2004 foram encontradas 13 reportagens referentes à desastres naturais associados às precipitações, nos meses de fevereiro, março, abril e também em dezembro, como pode ser aferido no Gráfico 27 e no Apêndice V. 


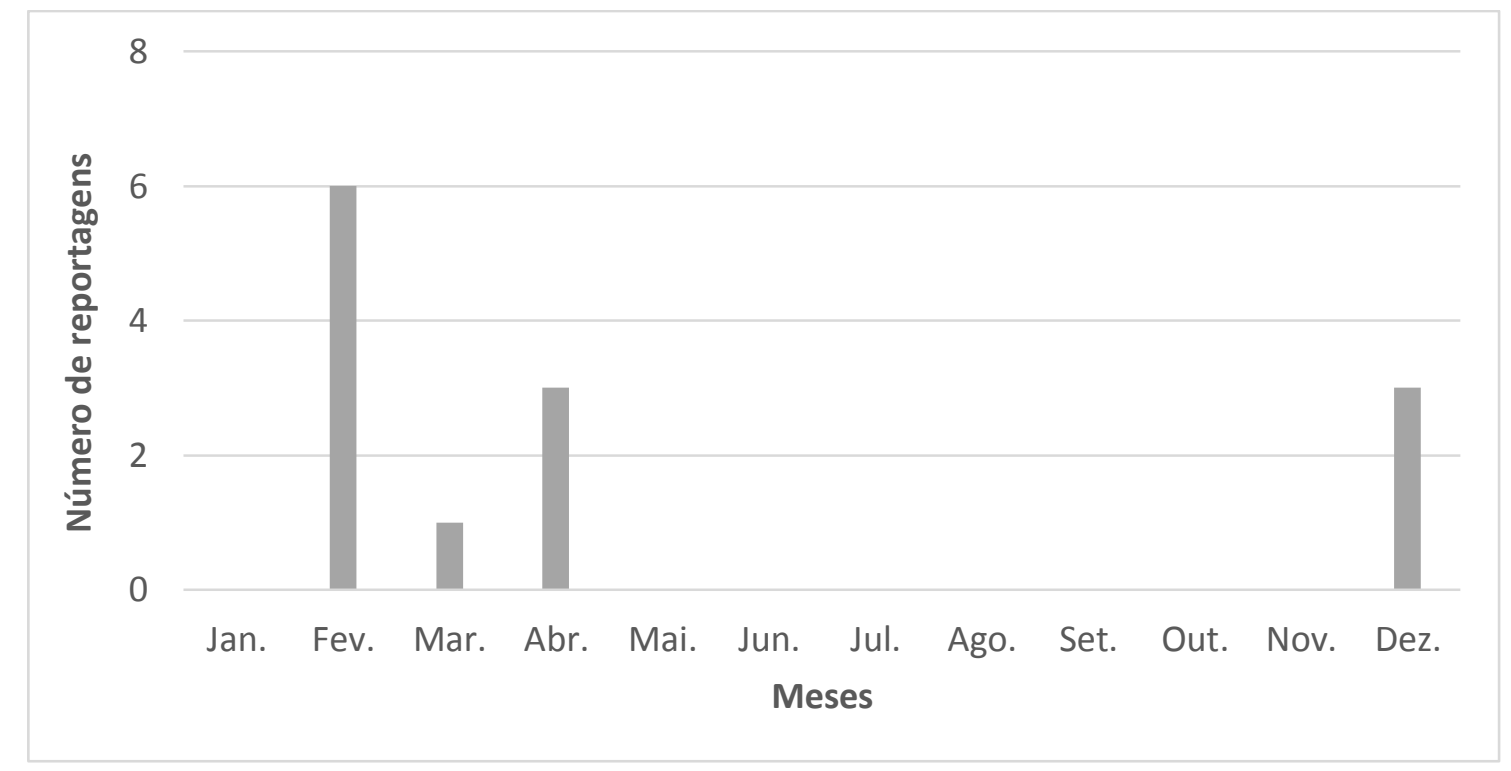

Gráfico 27. Número de reportagens encontradas mensalmente em 2004. Fonte dos dados: Correio Braziliense. Elaborado pelo autor.

De acordo com o que foi registrado nas reportagens, a Região Administrativa mais afetada foi o Plano Piloto (RA I), com 10 ocorrências de desastres; seguido por Itapoã (RA XXVII), com 4 ocorrências. SIA (RA XXIX), Lago Sul (RA XVI) e SCIA (RA XXV) apresentaram 3 ocorrências cada.

\begin{tabular}{|c|c|c|c|c|c|c|c|}
\hline $\begin{array}{l}\text { Região } \\
\text { Administrativa }\end{array}$ & Alagamento & Enxurrada & Erosão & Granizo & $\begin{array}{l}\text { Movimento } \\
\text { de Massa }\end{array}$ & Vendaval & Total \\
\hline Plano Piloto (RA I) & 6 & 0 & 0 & 0 & 0 & 4 & 10 \\
\hline Gama (RA II) & 0 & 0 & 0 & 0 & 1 & 0 & 1 \\
\hline Taguatinga (RA III) & 0 & 0 & 0 & 0 & 0 & 0 & 0 \\
\hline Brazlândia (RA IV) & 1 & 1 & 0 & 0 & 0 & 0 & 2 \\
\hline Sobradinho (RA V) & 0 & 0 & 0 & 0 & 0 & 0 & 0 \\
\hline Planaltina (RA VI) & 1 & 1 & 0 & 0 & 0 & 0 & 2 \\
\hline Paranoá (RA VII) & 0 & 0 & 0 & 0 & 0 & 0 & 0 \\
\hline $\begin{array}{l}\text { Núcleo } \\
\text { Bandeirante (RA } \\
\text { VIII) }\end{array}$ & 1 & 0 & 0 & 0 & 0 & 0 & 1 \\
\hline Ceilândia (RA IX) & 0 & 0 & 0 & 0 & 0 & 0 & 0 \\
\hline Guará (RA X) & 0 & 0 & 0 & 0 & 0 & 1 & 1 \\
\hline Cruzeiro (RA XI) & 0 & 0 & 0 & 0 & 0 & 0 & 0 \\
\hline $\begin{array}{l}\text { Samambaia (RA } \\
\text { XII) }\end{array}$ & 0 & 0 & 0 & 0 & 0 & 0 & 0 \\
\hline $\begin{array}{l}\text { Santa Maria (RA } \\
\text { XIII) }\end{array}$ & 0 & 0 & 0 & 0 & 0 & 0 & 0 \\
\hline $\begin{array}{l}\text { São Sebastião (RA } \\
\text { XIV) }\end{array}$ & 1 & 0 & 0 & 0 & 0 & 0 & 1 \\
\hline $\begin{array}{l}\text { Recanto das Emas } \\
\text { (RA XV) }\end{array}$ & 0 & 0 & 0 & 0 & 0 & 0 & 0 \\
\hline Lago Sul (RA XVI) & 1 & 2 & 0 & 0 & 0 & 0 & 3 \\
\hline Riacho Fundo (RA & 0 & 0 & 0 & 0 & 0 & 0 & 0 \\
\hline
\end{tabular}




\begin{tabular}{|c|c|c|c|c|c|c|c|}
\hline XVII) & & & & & & & \\
\hline $\begin{array}{l}\text { Lago Norte (RA } \\
\text { XVIII) }\end{array}$ & 0 & 0 & 0 & 0 & 0 & 0 & 0 \\
\hline $\begin{array}{l}\text { Candangolândia } \\
\text { (RA XIX) }\end{array}$ & 0 & 0 & 0 & 0 & 0 & 0 & 0 \\
\hline $\begin{array}{l}\text { Águas Claras (RA } \\
\mathrm{XX)}\end{array}$ & 0 & 0 & 0 & 0 & 0 & 1 & 1 \\
\hline $\begin{array}{l}\text { Riacho Fundo II (RA } \\
\text { XXI) }\end{array}$ & 0 & 0 & 0 & 0 & 0 & 0 & 0 \\
\hline $\begin{array}{l}\text { Sudoeste / } \\
\text { Octogonal (RA } \\
\text { XXII) }\end{array}$ & 0 & 0 & 0 & 0 & 0 & 0 & 0 \\
\hline Varjão (RA XXIII) & 0 & 0 & 0 & 0 & 1 & 0 & 1 \\
\hline $\begin{array}{l}\text { Park Way (RA } \\
\text { XXIV) }\end{array}$ & 0 & 0 & 0 & 0 & 0 & 0 & 0 \\
\hline $\begin{array}{l}\text { Setor } \\
\text { Complementar de } \\
\text { Indústria e } \\
\text { Abastecimento (RA } \\
\text { XXV) }\end{array}$ & 1 & 1 & 0 & 0 & 0 & 1 & 3 \\
\hline $\begin{array}{l}\text { Sobradinho II (RA } \\
\text { XXVI) }\end{array}$ & 0 & 0 & 0 & 0 & 0 & 0 & 0 \\
\hline $\begin{array}{l}\text { Jardim Botânico } \\
\text { (RA XXVII) }\end{array}$ & 0 & 0 & 0 & 0 & 0 & 0 & 0 \\
\hline Itapoã (RA XXVII) & 1 & 1 & 0 & 0 & 1 & 1 & 4 \\
\hline $\begin{array}{l}\text { Setor de Indústria } \\
\text { e Abastecimento } \\
\text { (RA XXIX) }\end{array}$ & 1 & 1 & 0 & 0 & 0 & 1 & 3 \\
\hline $\begin{array}{l}\text { Vicente Pires (RA } \\
\text { XXX) }\end{array}$ & 1 & 0 & 0 & 0 & 0 & 1 & 2 \\
\hline Fercal (RA XXXI) & 0 & 0 & 0 & 0 & 0 & 0 & 0 \\
\hline Total & 15 & 7 & 0 & 0 & 3 & 10 & 35 \\
\hline
\end{tabular}

Quadro 6. Número de reportagens encontradas mensalmente em 2004 com tipologia de desastres naturais. Elaborado pelo autor.

Em relação à tipologia de desastres naturais, os alagamentos foram os desastres naturais que ocorreram com maior frequência, sendo observados 15 vezes nas Regiões Administrativas; seguidos por vendavais, com 10 ocorrências; enxurradas, com 7 ocorrências; e movimentos de massa, com 3 ocorrências. As porcentagens de cada tipo de desastres podem ser observadas no Gráfico 28. 


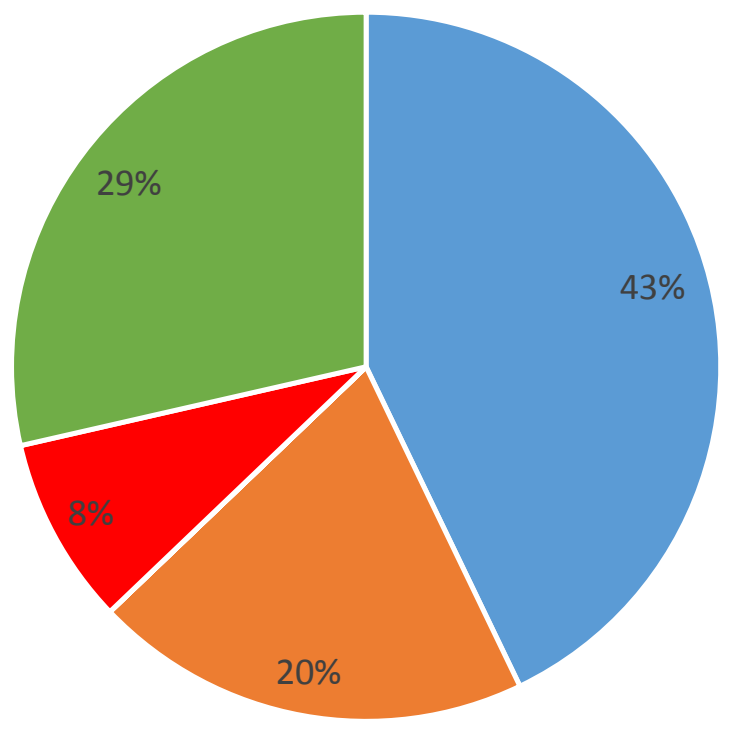

- Alagamento

- Enxurrada

- Movimento de Massa

- Vendaval

Gráfico 28. Porcentagem de desastres naturais encontrados nas reportagens ocorridos em 2004. Elaborado pelo autor.

Dentre as reportagens do ano de 2004, destaca-se duas do mês de fevereiro, que foi um dos meses mais chuvosos estudados entre 2000 e 2010, tendo registrado 422,3 $\mathrm{mm}$ na Estação Brasília do INMET. Nesse ano, os alagamentos e ventanias assolaram o DF, sobretudo o Plano Piloto, provocando o fechamento de tesourinhas, quedas de árvores e até mesmo mortes.

Uma pessoa morreu atropelada durante temporal perto do ParkShopping. Na Asa Sul, tesourinhas ficaram alagadas e um carro foi atingido por árvore. Previsão é de tempo fechado até domingo

\section{Estragos que não têmfim}
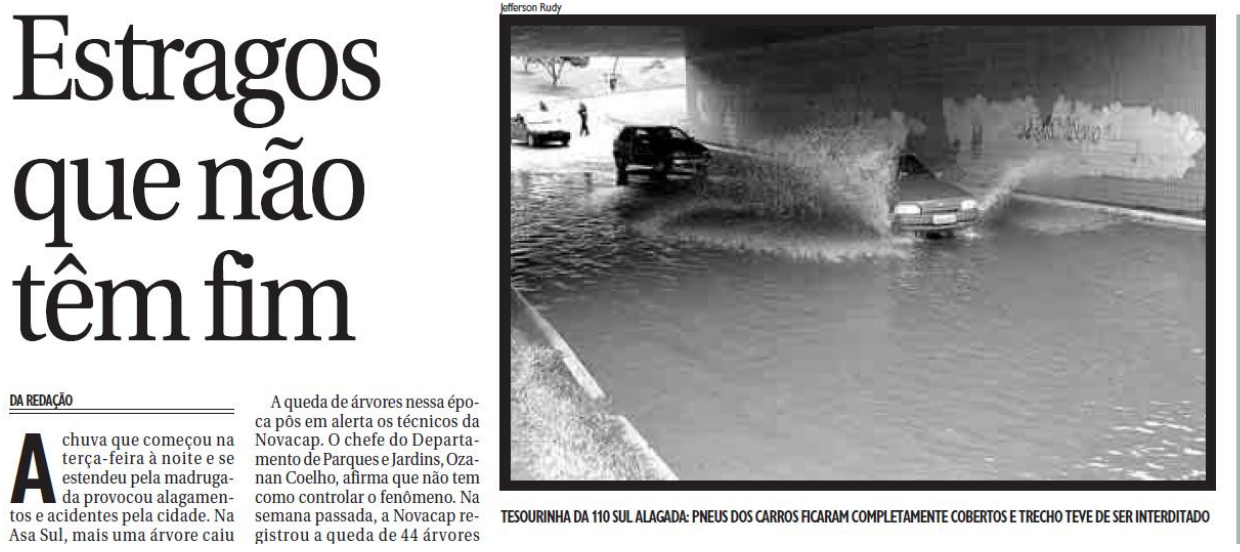

Evitando os transtornos

A previsão do Inmet é que
as chuvas durem até abril. as chuvas durem até abril. dem ser tomados para diminuir riscos e prejuízos. De beiros e a Defesa Civil, atitudes simples ajudam a evitar áidentes, como quedas de inundaçōes, "Como as precipitações estão mais fortes, as pessoas devem desenvolver percepção de riscos e tomar alguns cuidados. Se as recodas, muitos prejuizos e perdas poderiam ser evitados", adverte o subsecretário de Defesa Civil, Nilo Abreu.

Oscuidados, segundo ele,

Figura 15. Recorte de reportagem de fevereiro de 2004 (Apêndice $V$, Notícia $n^{\circ}$ 6). Fonte: Correio Braziliense. 


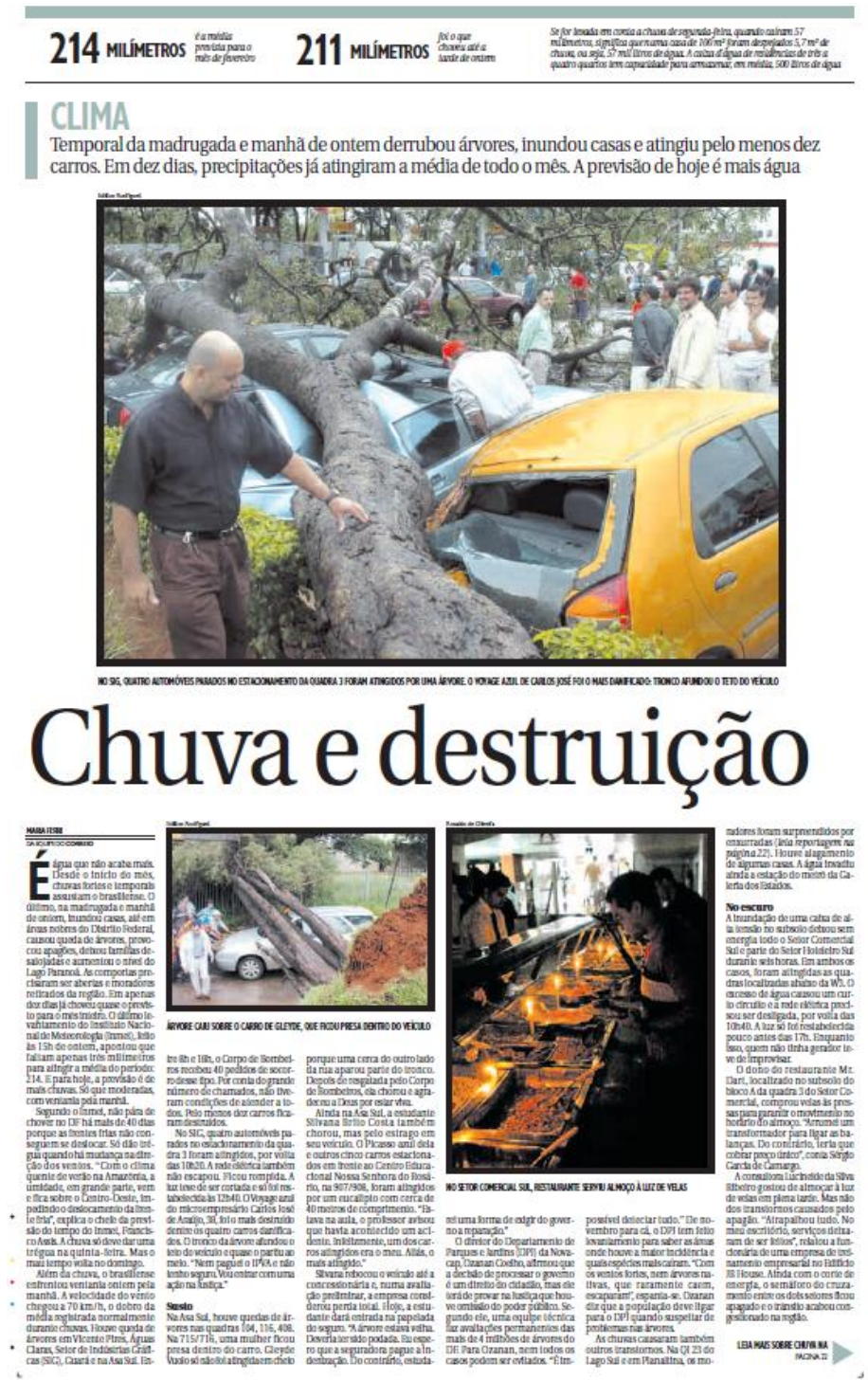

Figura 16. Recorte de reportagem de fevereiro de 2004 (Apêndice V, Notícia no 4). Fonte: Correio Braziliense.

\subsubsection{Ano de 2005}

O ano de 2005 foi um ano chuvoso. A Estação Brasília do INMET registrou um total de precipitação acumulada anualmente de 1760,1 mm de chuva (Gráfico 28), aproximadamente 14,2\% acima da média de precipitação anual da Normal Climatológica e a Estação Roncador do INMET registrou 1635,8 mm, cerca de 29\% abaixo da Normal, que é de 1540,6 mm (Gráfico 29).

$\mathrm{Na}$ primeira etapa do período chuvoso no ano, em janeiro e abril, as chuvas foram abaixo da média, superando a Normal em fevereiro e março, 
sendo que este último apresentou um volume atípico na Estação Brasília para o mês (398,6 mm, contra 180,6 mm da média histórica mensal). O período chuvoso foi retomado timidamente em agosto, setembro e outubro, que foram abaixo da média também e em novembro e dezembro as precipitações voltaram com força, retomando a regularidade e ficando acima dos $300 \mathrm{~mm}$ na Estação Roncador.

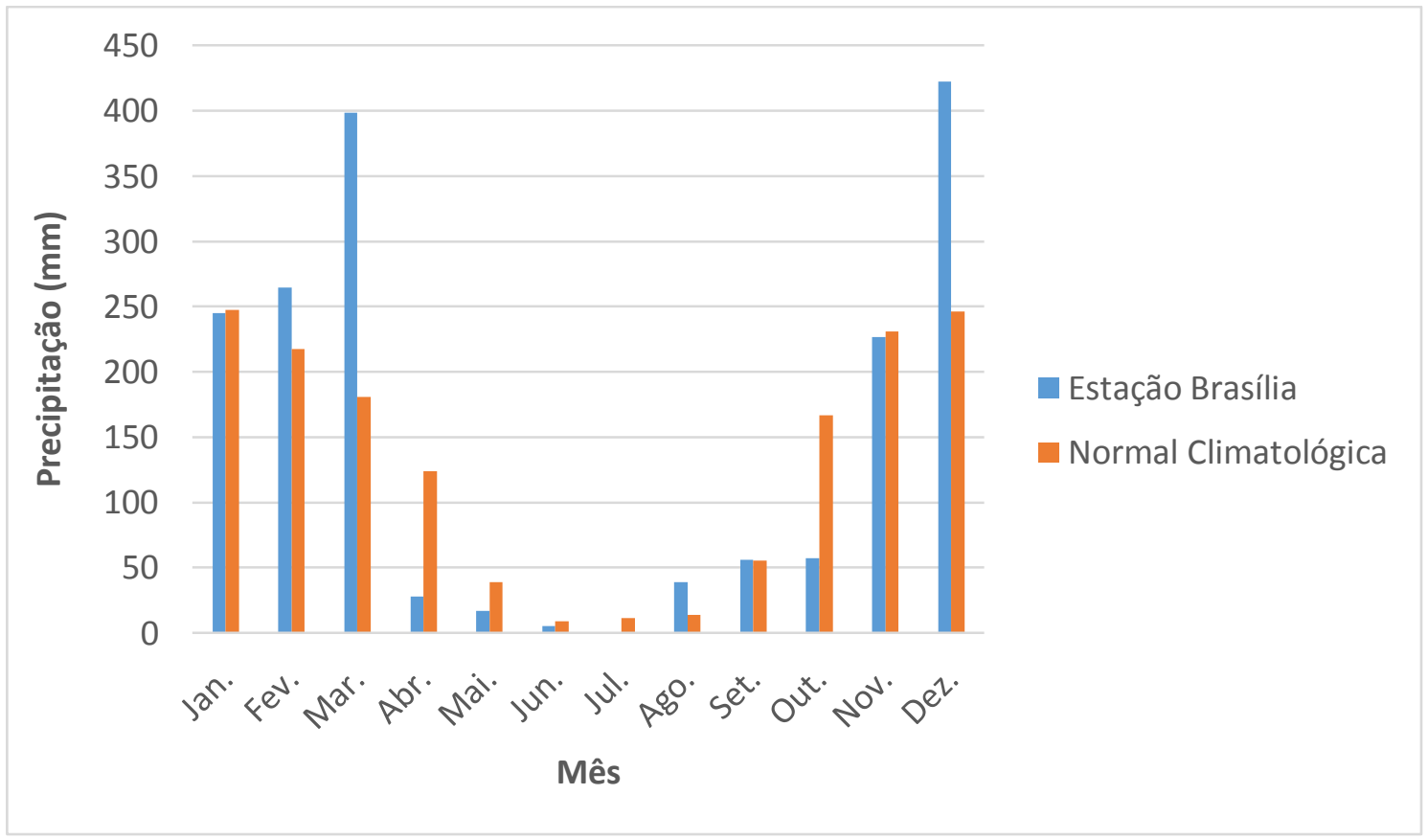

Gráfico 28. Precipitação mensal acumulada em 2005 na Estação Brasília do INMET (DF).

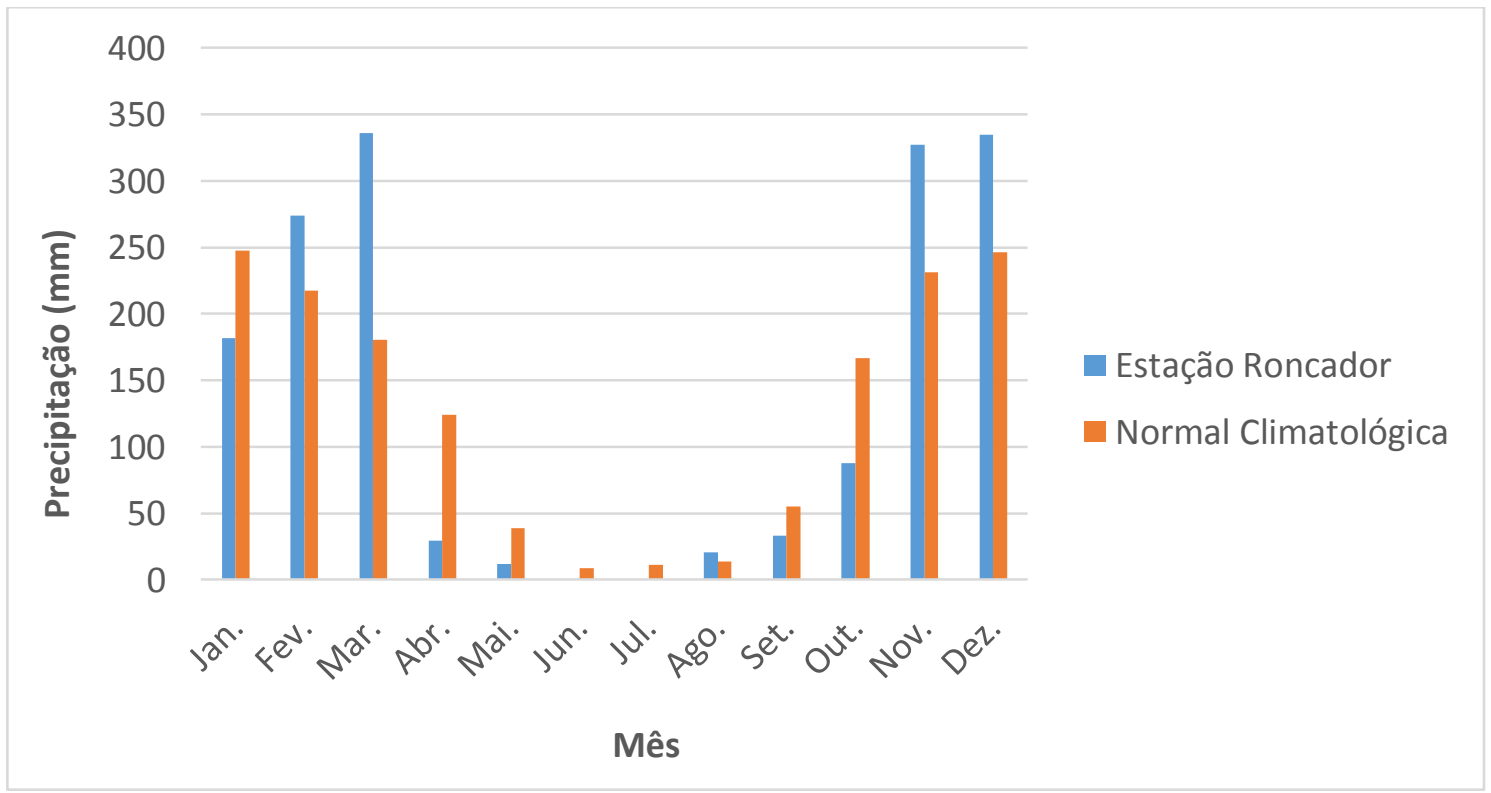

Gráfico 29. Precipitação mensal acumulada em 2005 na Estação Roncador do INMET (DF). 
Em 2005 foram encontradas 15 reportagens referentes à desastres naturais associados às precipitações, nos meses de fevereiro, março, setembro, novembro e dezembro, como pode ser aferido no Gráfico 30 e no Apêndice VI.

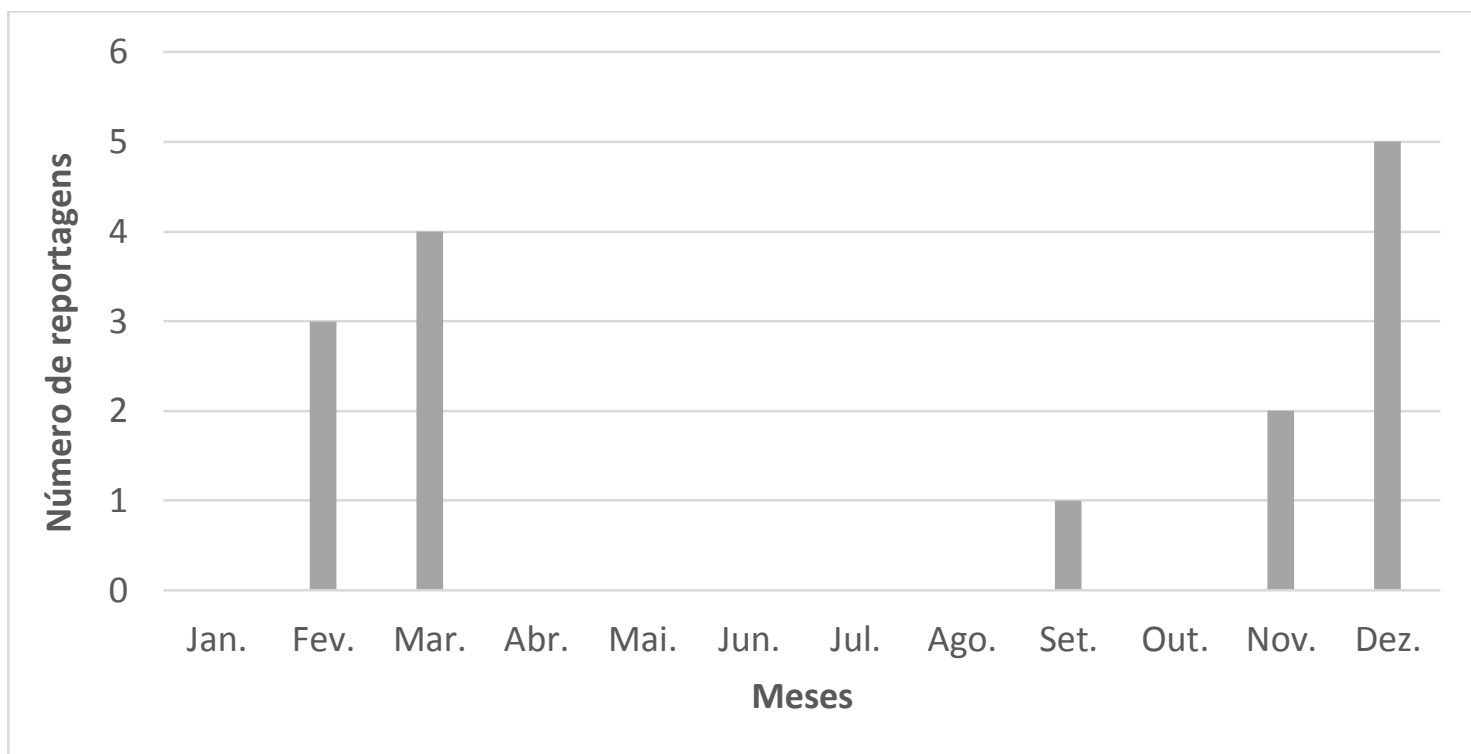

Gráfico 30. Número de reportagens encontradas mensalmente em 2005. Fonte dos dados: Correio Braziliense. Elaborado pelo autor.

De acordo com o que foi registrado nas reportagens, a Região Administrativa mais afetada foi o Plano Piloto (RA I), com 8 ocorrências de desastres, seguido por Sobradinho (RA V), Paranoá (RA VII), Núcleo Bandeirante (RA VIII), SCIA (RA XXV) e Sobradinho II (RA XXVI) com 2 ocorrências.

\begin{tabular}{|c|c|c|c|c|c|c|c|}
\hline $\begin{array}{l}\text { Região } \\
\text { Administrativa }\end{array}$ & Alagamento & Enxurrada & Erosão & Granizo & Movimento de Massa & Vendaval & Total \\
\hline $\begin{array}{l}\text { Plano Piloto } \\
\text { (RA I) }\end{array}$ & 4 & 1 & 0 & 1 & 0 & 2 & 8 \\
\hline Gama (RA II) & 0 & 0 & 0 & 0 & 0 & 0 & 0 \\
\hline $\begin{array}{l}\text { Taguatinga (RA } \\
\text { III) }\end{array}$ & 0 & 0 & 0 & 0 & 0 & 0 & 0 \\
\hline $\begin{array}{l}\text { Brazlândia (RA } \\
\text { IV) }\end{array}$ & 0 & 0 & 1 & 0 & 0 & 0 & 1 \\
\hline $\begin{array}{l}\text { Sobradinho (RA } \\
\text { V) }\end{array}$ & 2 & 0 & 0 & 0 & 0 & 0 & 2 \\
\hline $\begin{array}{l}\text { Planaltina (RA } \\
\text { VI) }\end{array}$ & 0 & 0 & 0 & 0 & 0 & 0 & 0 \\
\hline $\begin{array}{l}\text { Paranoá (RA } \\
\text { VII) }\end{array}$ & 1 & 1 & 0 & 0 & 0 & 0 & 2 \\
\hline Núcleo & & & & & & & \\
\hline $\begin{array}{l}\text { Bandeirante } \\
\text { (RA VIII) }\end{array}$ & 1 & 1 & 0 & 0 & 0 & 0 & 2 \\
\hline
\end{tabular}




\begin{tabular}{|c|c|c|c|c|c|c|c|}
\hline $\begin{array}{l}\text { Ceilândia (RA } \\
\text { IX) }\end{array}$ & 1 & 0 & 0 & 0 & 0 & 0 & 1 \\
\hline Guará (RA X) & 0 & 0 & 0 & 0 & 0 & 0 & 0 \\
\hline Cruzeiro (RA XI) & 0 & 0 & 0 & 0 & 0 & 0 & 0 \\
\hline $\begin{array}{l}\text { Samambaia (RA } \\
\text { XII) }\end{array}$ & 0 & 0 & 0 & 0 & 0 & 0 & 0 \\
\hline $\begin{array}{l}\text { Santa Maria } \\
\text { (RA XIII) }\end{array}$ & 0 & 0 & 0 & 0 & 0 & 0 & 0 \\
\hline $\begin{array}{l}\text { São Sebastião } \\
\text { (RA XIV) }\end{array}$ & 0 & 0 & 0 & 0 & 0 & 0 & 0 \\
\hline $\begin{array}{l}\text { Recanto das } \\
\text { Emas (RA XV) }\end{array}$ & 0 & 0 & 0 & 0 & 0 & 0 & 0 \\
\hline $\begin{array}{l}\text { Lago Sul (RA } \\
\text { XVI) }\end{array}$ & 0 & 0 & 0 & 0 & 0 & 0 & 0 \\
\hline $\begin{array}{l}\text { Riacho Fundo } \\
\text { (RA XVII) }\end{array}$ & 0 & 0 & 0 & 0 & 0 & 0 & 0 \\
\hline $\begin{array}{l}\text { Lago Norte (RA } \\
\text { XVIII) }\end{array}$ & 0 & 0 & 0 & 0 & 0 & 0 & 0 \\
\hline $\begin{array}{l}\text { Candangolândia } \\
\text { (RA XIX) }\end{array}$ & 0 & 0 & 0 & 0 & 0 & 0 & 0 \\
\hline $\begin{array}{l}\text { Águas Claras } \\
\text { (RA XX) }\end{array}$ & 0 & 0 & 0 & 0 & 0 & 0 & 0 \\
\hline $\begin{array}{l}\text { Riacho Fundo II } \\
\text { (RA XXI) }\end{array}$ & 0 & 0 & 0 & 0 & 0 & 0 & 0 \\
\hline Sudoeste / & & & & & & & \\
\hline $\begin{array}{l}\text { Octogonal (RA } \\
\text { XXII) }\end{array}$ & 0 & 0 & 0 & 0 & 0 & 0 & 0 \\
\hline $\begin{array}{l}\text { Varjão (RA } \\
\text { XXIII) }\end{array}$ & 0 & 0 & 0 & 0 & 0 & 0 & 0 \\
\hline $\begin{array}{l}\text { Park Way (RA } \\
\text { XXIV) }\end{array}$ & 0 & 0 & 0 & 0 & 0 & 0 & 0 \\
\hline $\begin{array}{l}\text { Setor } \\
\text { Complementar } \\
\text { de Indústria e } \\
\text { Abastecimento } \\
\text { (RA XXV) }\end{array}$ & 2 & 0 & 0 & 0 & 0 & 0 & 2 \\
\hline $\begin{array}{l}\text { Sobradinho II } \\
\text { (RA XXVI) }\end{array}$ & 0 & 0 & 1 & 0 & 0 & 1 & 2 \\
\hline $\begin{array}{l}\text { Jardim Botânico } \\
\text { (RA XXVII) }\end{array}$ & 0 & 0 & 0 & 0 & 0 & 0 & 0 \\
\hline $\begin{array}{l}\text { Itapoã (RA } \\
\text { XXVII) }\end{array}$ & 0 & 0 & 0 & 0 & 0 & 0 & 0 \\
\hline $\begin{array}{l}\text { Setor de } \\
\text { Indústria e } \\
\text { Abastecimento } \\
\text { (RA XXIX) }\end{array}$ & 0 & 0 & 0 & 0 & 0 & 0 & 0 \\
\hline $\begin{array}{l}\text { Vicente Pires } \\
\text { (RA XXX) }\end{array}$ & 1 & 1 & 0 & 0 & 0 & 0 & 2 \\
\hline Fercal (RA XXXI) & 0 & 0 & 0 & 0 & 0 & 0 & 0 \\
\hline Total & 12 & 4 & 2 & 1 & 0 & 3 & 22 \\
\hline
\end{tabular}

Quadro 7. Número de reportagens encontradas mensalmente em 2005 com tipologia de desastres naturais. Elaborado pelo autor. 
Em relação à tipologia de desastres naturais, os alagamentos foram os desastres naturais que ocorreram com maior frequência, sendo observados 12 vezes nas Regiões Administrativas; seguidos por enxurradas, com 4 ocorrências; vendavais, com 3 ocorrências; erosão, com 2 ocorrências; e queda de granizo, com uma ocorrência. As porcentagens de cada tipo de desastres podem ser observadas no Gráfico 31.

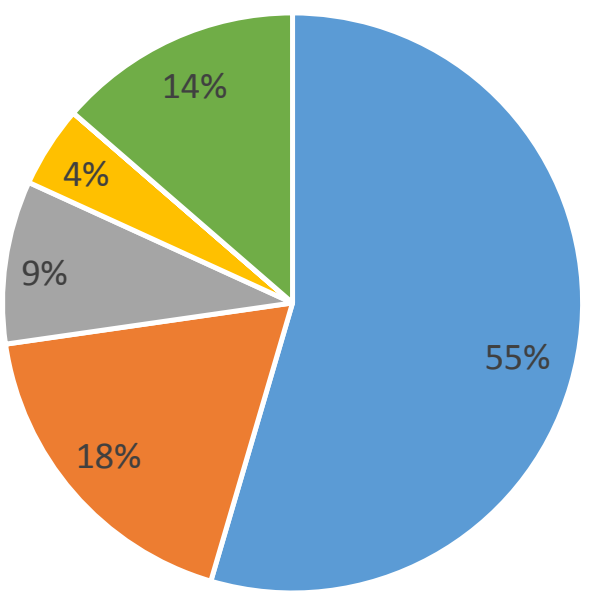

- Alagamento

- Enxurrada

- Erosão

- Granizo

- Vendaval

Gráfico 31. Porcentagem de desastres naturais encontrados nas reportagens ocorridos em 2005. Elaborado pelo autor.

No ano de 2005 destacam-se três reportagens, que ocuparam folhas inteiras do caderno Cidades. A primeira mostra que fortes chuvas atingiram o DF, o que ocasionou alagamentos no Plano Piloto, enxurradas em Vicente Pires e inundações em casa em Sobradinho.

A segunda mostra como a água da chuva catalisou o rompimento e colapso de trecho da DF-170, que liga o Lago Oeste à Brazlândia, e deixou famílias isoladas.

A terceira mostra a força dos vendavais que aconteceram em dezembro, apontando áreas de riscos para esse tipo de desastre na cidade, como Planaltina e Ceilândia. Introdução de espécies exóticas ao Cerrado para o projeto urbanístico na construção da capital é apontada como uma das causas das quedas de árvores. 
Chuvas fortes tumultuam o trânsito e provocam transtorno para o brasiliense na hora de voltar para casa.

CEB abre as comportas da barragem do Paranoá e Bombeiros alertam população às margens do lago

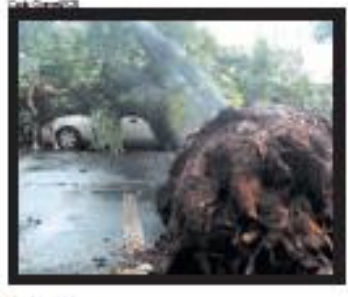

SUsto

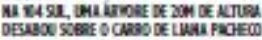

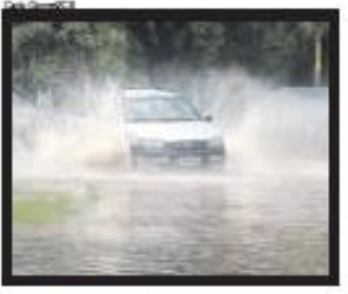

ERUNHo Morre

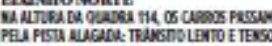

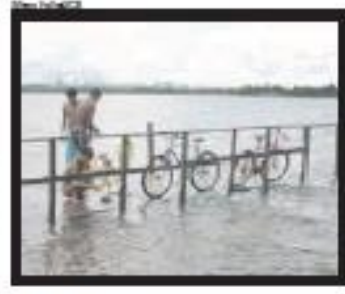

LMGopurusas

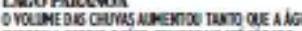

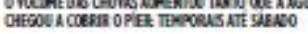

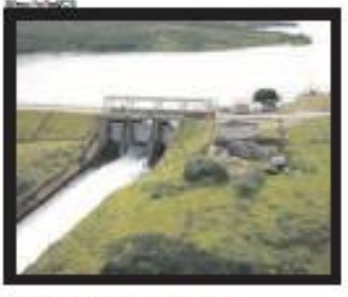

BABGLACIM DOPARUNOS

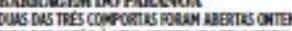

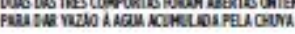

\section{Temporais assustam moradores}
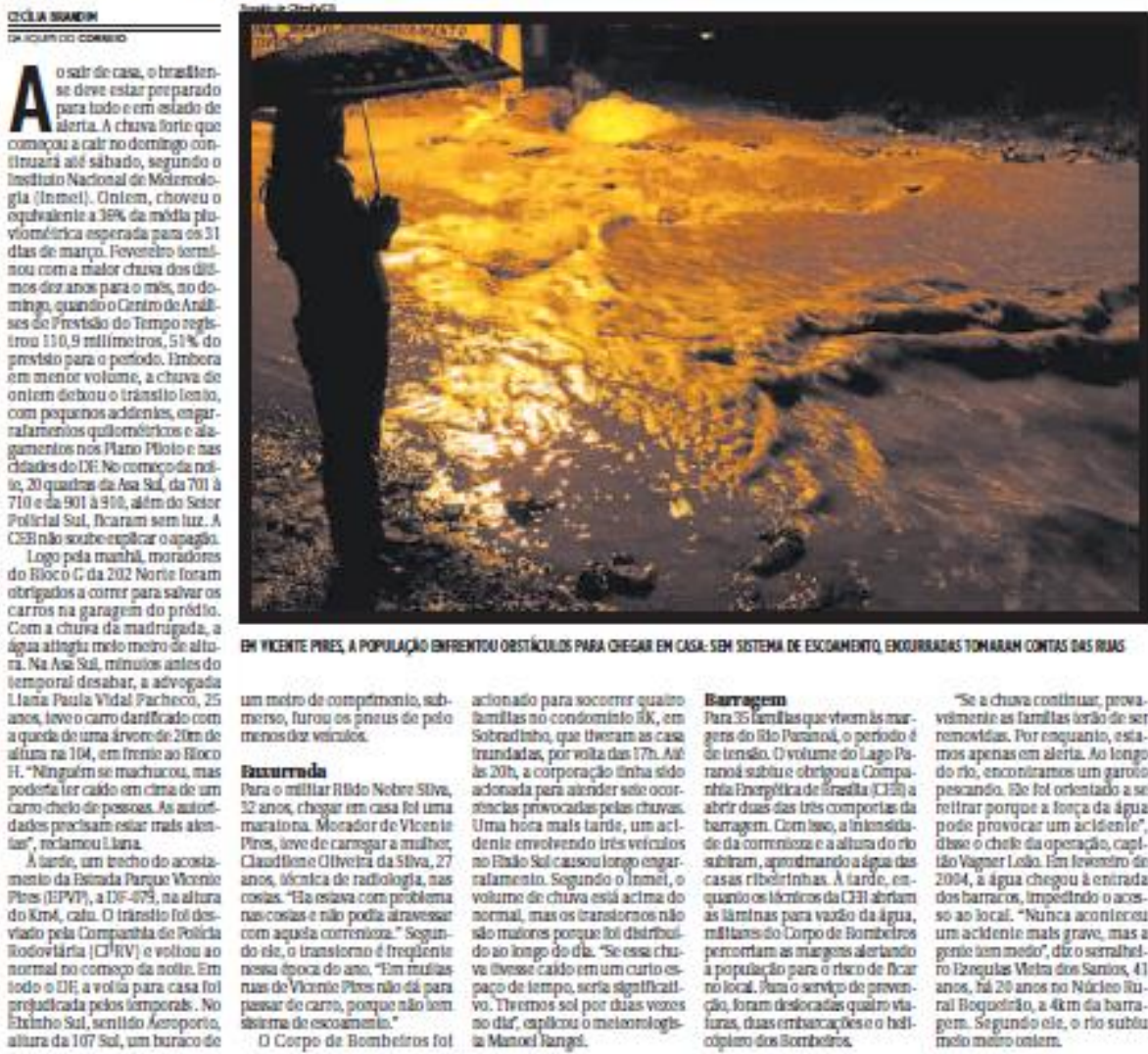

FAMÍLAS REMOVIDAS

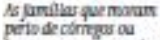

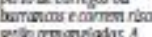

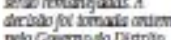

peb Cxemodo Ditrito omoperivenodaranes malspracipanzes malspracipanzis onde ardar 150 jorilly

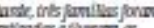

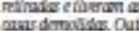

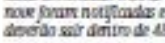
brax De acouda mus nojor riveono DF ato as

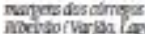
Norix $e$ iharto Panis. aive o Cansís o Nich

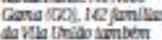

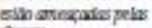

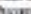
Ascomporias frarso atweias

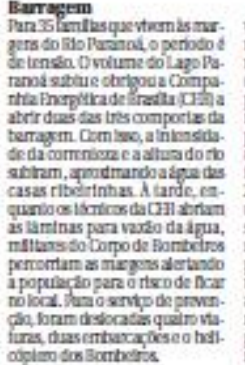

Se achisac continur, prov.

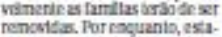

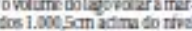

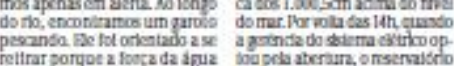

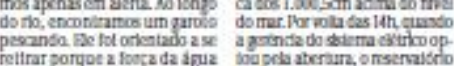

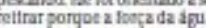
pote provocar umn acisenile

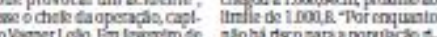

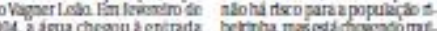

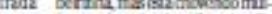

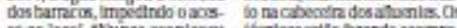

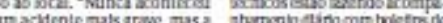

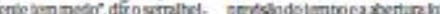

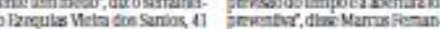
anos, thid 20 anos no Nírieo oin.

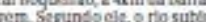

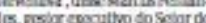

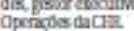

couscouchenm carsecio

Figura 17. Recorte de reportagem de março de 2005 (Apêndice $V$

I, Notícia no 4). Fonte: Correio Braziliense. 
ETRADAS

Parte da pista desmoronou após cónego Taquara transbordar e romper bueiro que passava soba DF-170. Água e lama invadiram chácaras e deixaram familias isoladas no km 4

\section{Chuva abre cratera em rodovia}
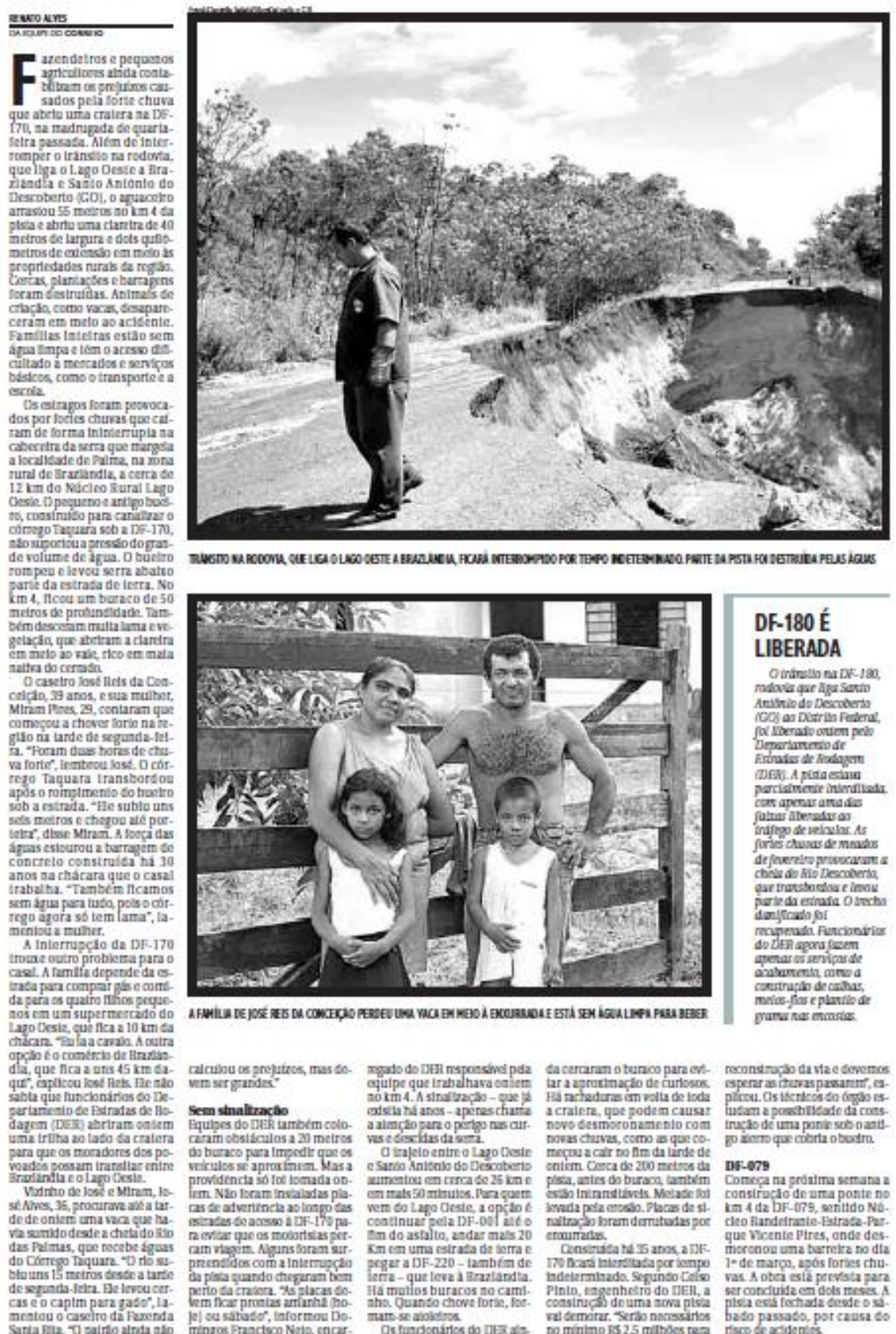

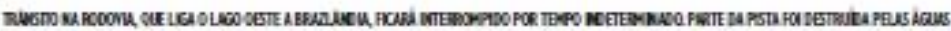

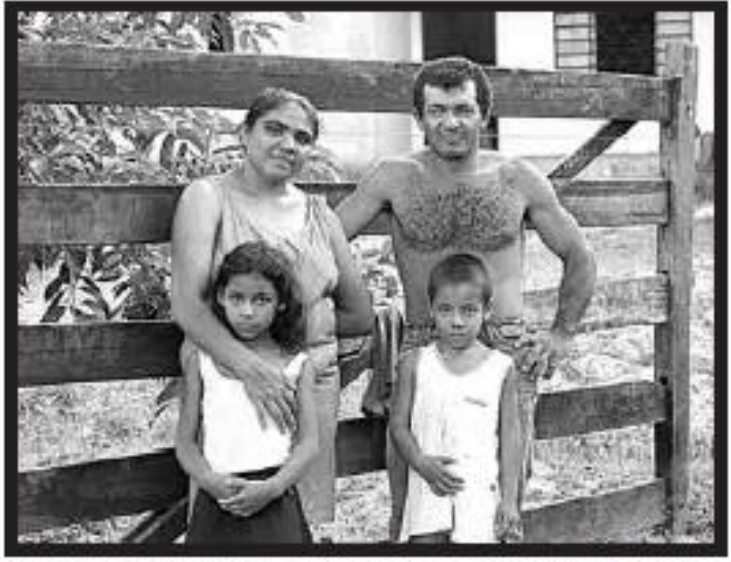

DF-180 É

LIBERADA

Ointretson nat 120

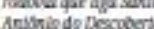

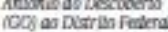

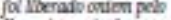
Deporimintiode Arrudes de hadazon

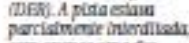
com aposirarnades fulmis abetrids as

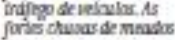
deforeztroprovocasin: chisu dis his Deecoborts

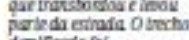

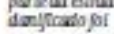

renpentala Runcianirios do Dles apovafwen

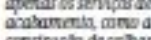

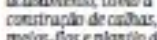
gursines mourtas.

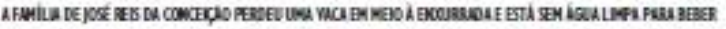

calcubue us prejutios, mas to.

sem strattracto

Equipes do DEFis tambim colodo buracs para limpedlr ques

vorulos seaprainimin. Stas a

providentra so foct tomada on. irm. Nin loram insialisas pla.

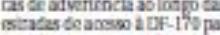
netiar ye os moborisias per. am rigem Nizuns Snaras sur.

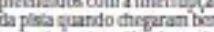

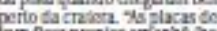

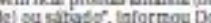

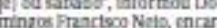

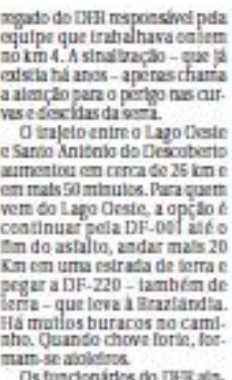

ta carraran o tunco parnes.

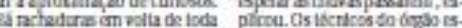

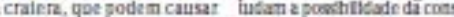
howo desmoronazarenio com inuclo de uma ponir spboant. bovas chaves, cormo as queces.

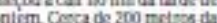
Dr-079

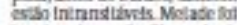

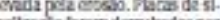

Consinda his anos, ant INW Bara hilertatapar ienpe Pinto, engenhespro do ment, a

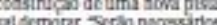
pominima is 25 milmos teas
Dr-079 consiruclóde uma ponte no $\ln 4$ da bF-079, senttdo Na. que vicenis Virs, ande des. T-de naros, avós forias chu. ser conduifa en dols moser A histo pasaso porcaesa to risco ex ardentias

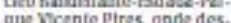
vas suta isia pertsta par

Figura 18. Recorte de reportagem de março de 2005 (Apêndice VI, Notícia nํ6). Fonte: Correio Braziliense. 

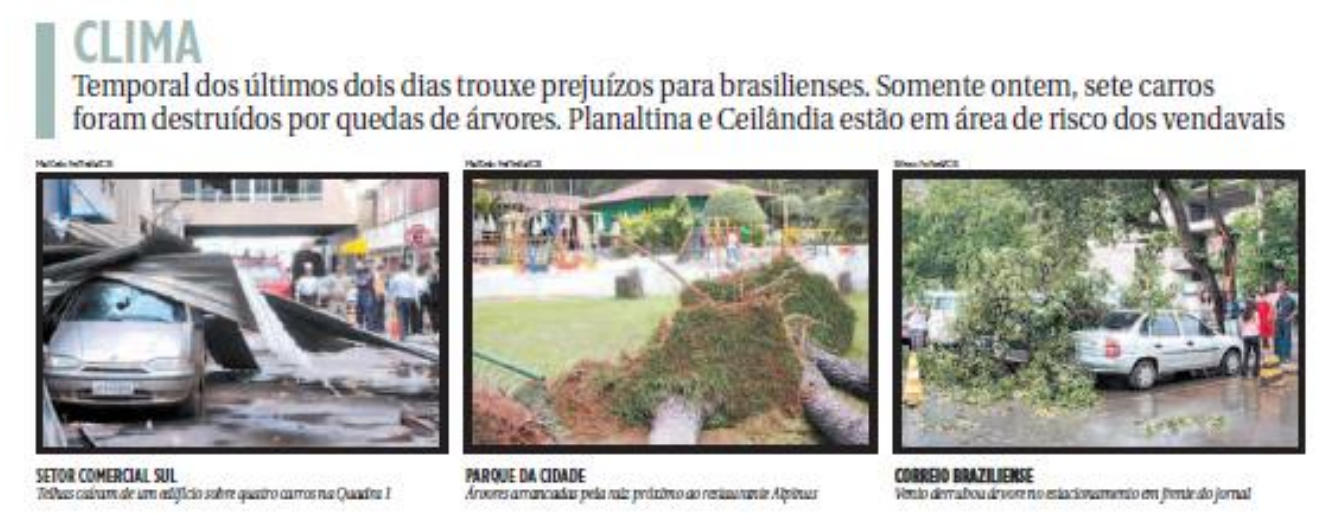

\section{Mais um mês de ventos fortes}

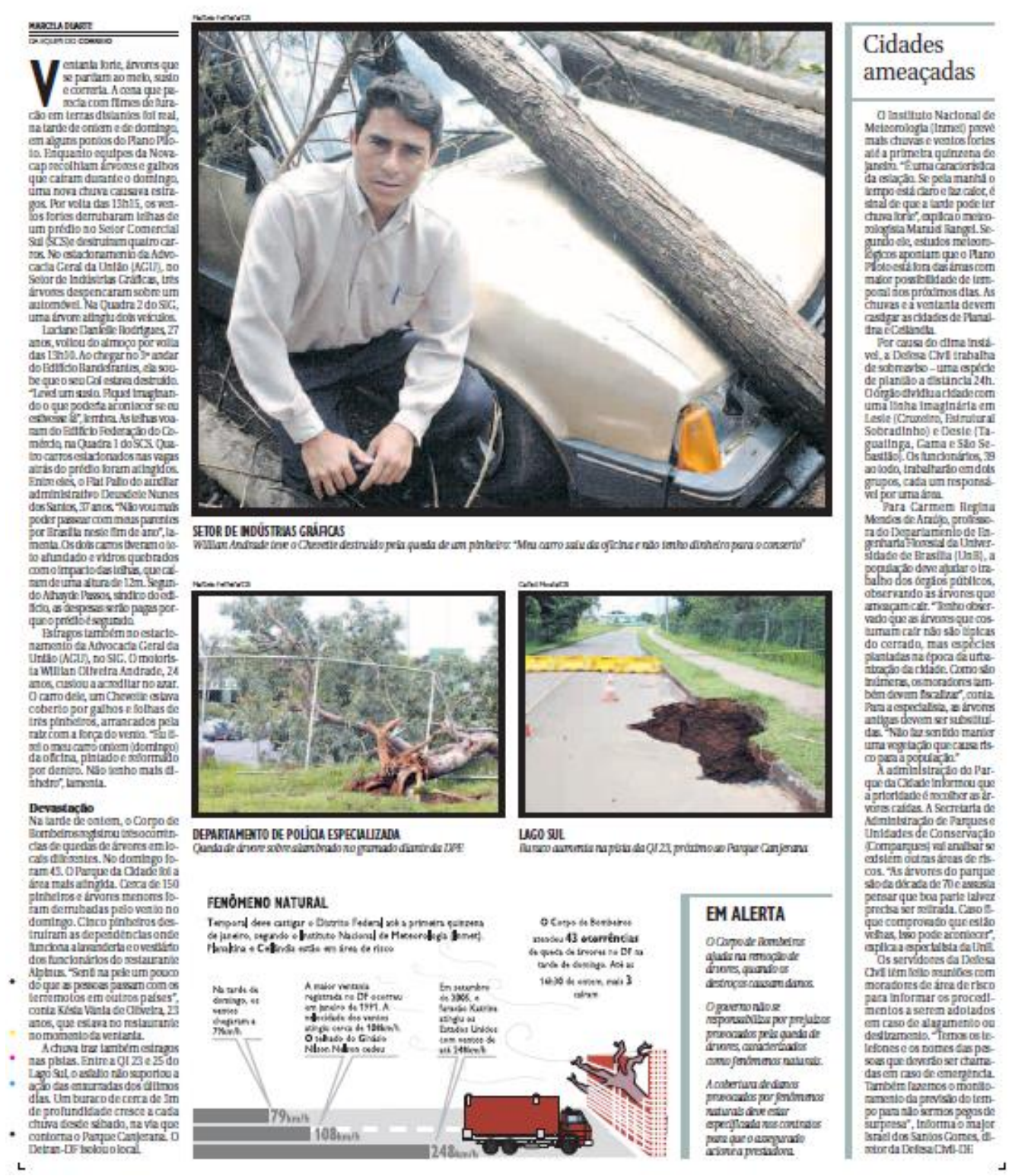

Figura 19. Recorte de reportagem de março de 2005 (Apêndice VI, Notícia no 15). Fonte: Correio Braziliense. 


\subsubsection{Ano de 2006}

Da série de anos estudados, o ano de 2006 foi o que apresentou a maior frequência de desastres naturais, mesmo não tendo sido o mais chuvoso no total de precipitação acumulado anualmente. A Estação Brasília do INMET registrou um total de precipitação acumulada anualmente de $1747,1 \mathrm{~mm}$ de chuva (Gráfico 32), aproximadamente $13,4 \%$ acima da média de precipitação anual da Normal Climatológica e a Estação Roncador do INMET registrou 1668 mm, cerca de 8\% acima da Normal, que é de 1540,6 mm (Gráfico 33).

Em janeiro e fevereiro, as chuvas foram abaixo da média, superando a Normal em março e decaindo para próximo e abaixo da média em abril. sendo que este último apresentou um volume atípico na Estação Brasília para o mês (398,6 mm, contra 180,6 mm da média histórica mensal). O período chuvoso se iniciou novamente em agosto, mantendo-se próximo da média entre setembro e dezembro, à exceção do mês de outubro.

O mês de outubro foi completamente atípico aos demais, tendo registrado somente na Estação Brasília do INMET impressionantes 526,4 mm, mais que o triplo da média histórica do mês, que é de 166,6 mm. Esse acúmulo de precipitações nesse mês se deve aos episódios seguidos de ZCAS no mês (INMET, s.a.; Steinke, Rezende, Cavalcanti, 2006; Coelho, Peres, Steinke, 2014). 


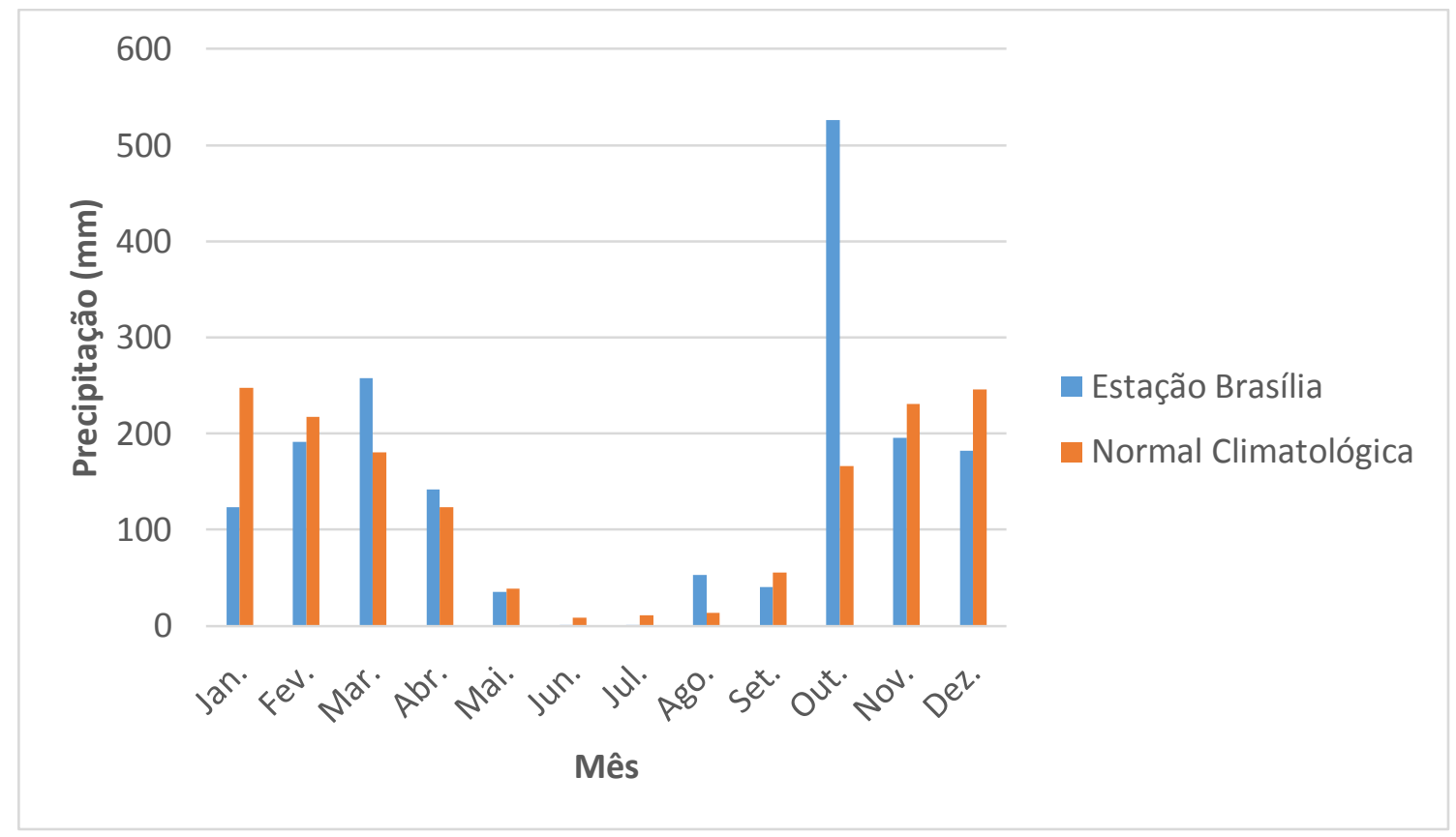

Gráfico 32. Precipitação mensal acumulada em 2006 na Estação Brasília do INMET (DF).

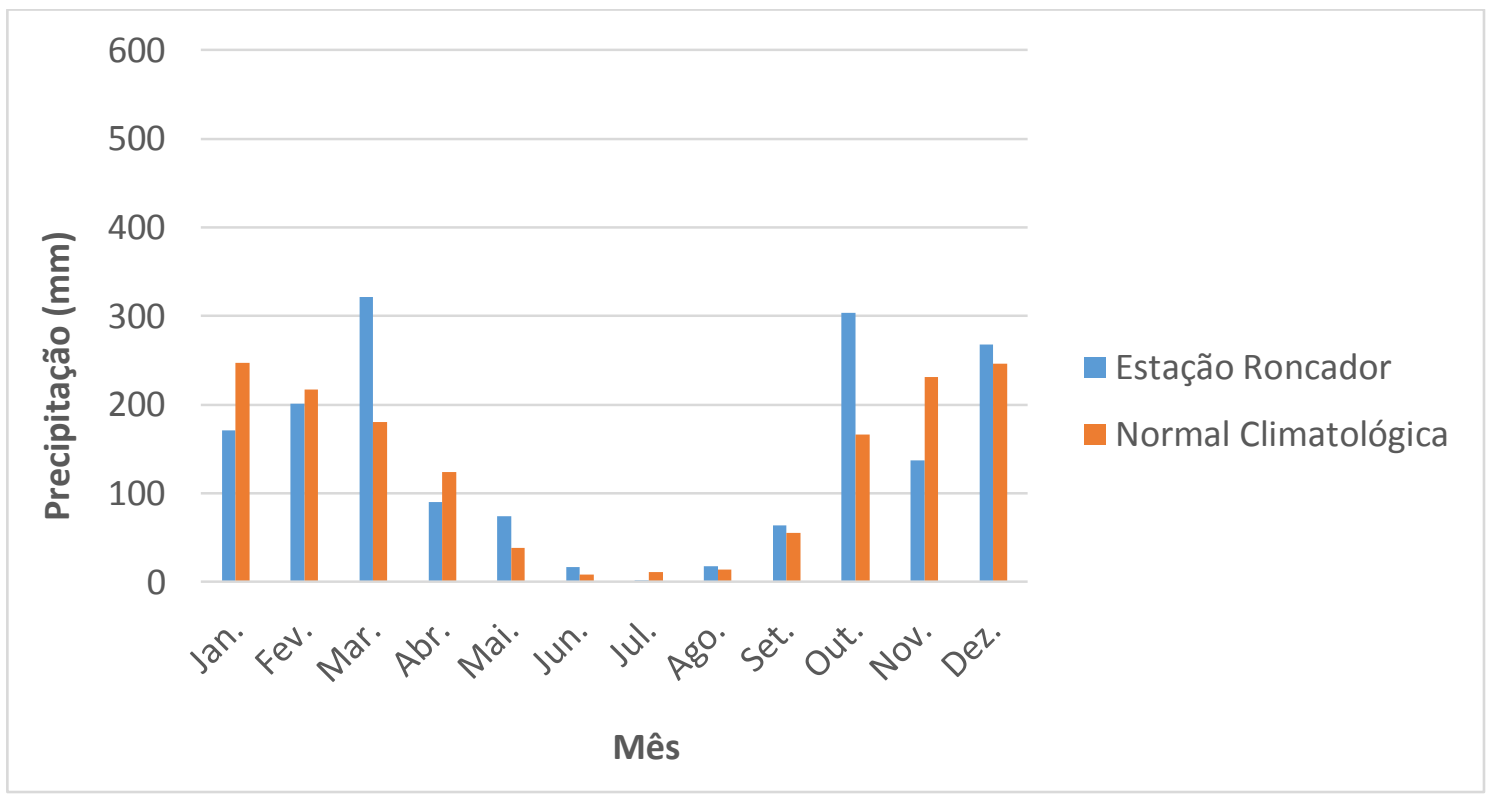

Gráfico 33. Precipitação mensal acumulada em 2006 na Estação Roncador do INMET (DF).

Em 2006 foram encontradas 36 reportagens referentes à desastres naturais associados às precipitações, em janeiro, fevereiro, março, abril, agosto, outubro, novembro e dezembro, como pode ser aferido no Gráfico 34 e no Apêndice VII. 


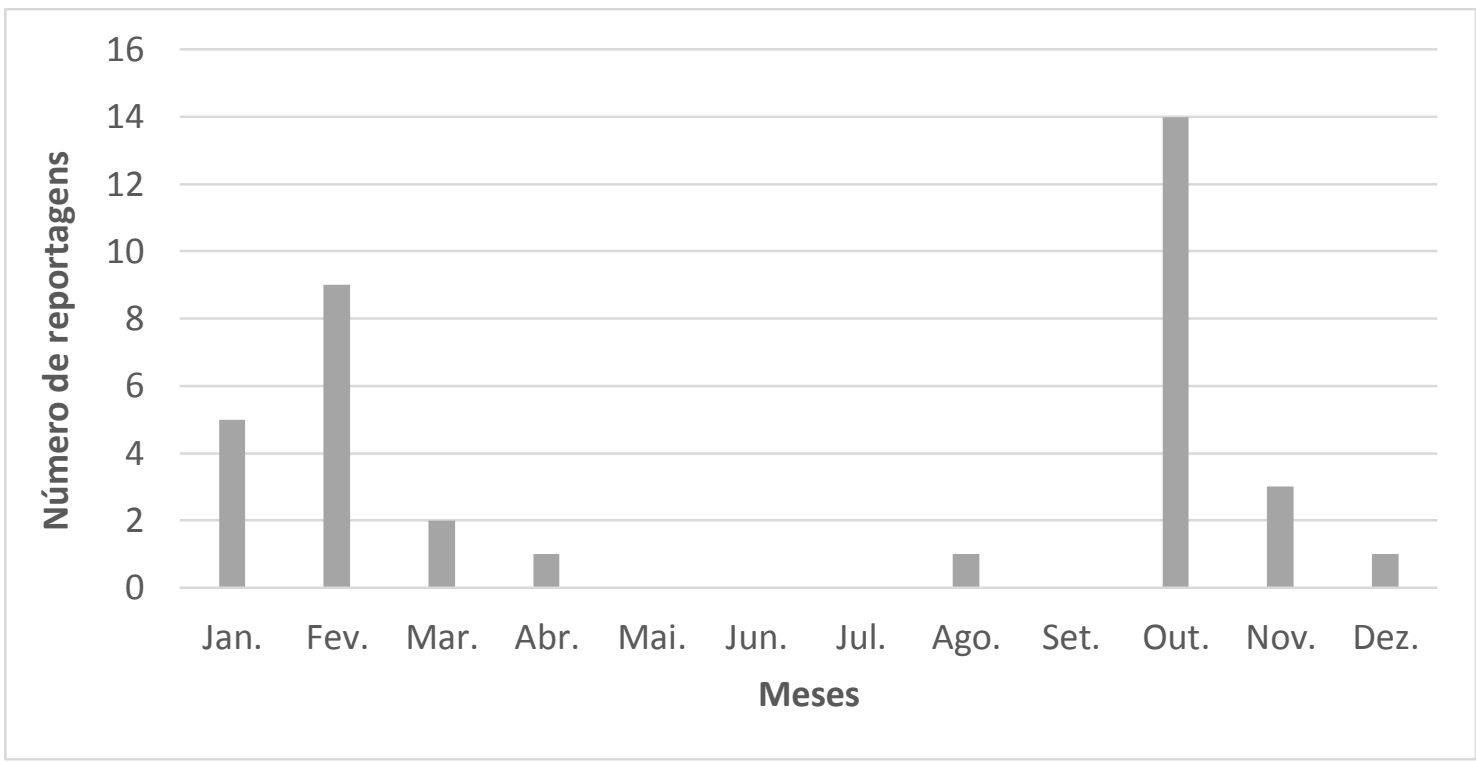

Gráfico 34. Número de reportagens encontradas mensalmente em 2006. Fonte dos dados: Correio Braziliense. Elaborado pelo autor.

De acordo com o que foi registrado nas reportagens, a Região Administrativa mais afetada foi o Plano Piloto (RA I), com 19 ocorrências de desastres; seguido por Ceilândia (RA IX), com 10 ocorrências; Varjão (RA XXIII), com 8 ocorrências; Sobradinho (RA V) e Itapoã (RA XXVII), com 7 ocorrências; Paranoá (RA VII) e Samambaia (RA XII), com 6 ocorrências. Somente 5 RA's não apresentaram ocorrência de desastres naturais.

\begin{tabular}{|c|c|c|c|c|c|c|c|}
\hline $\begin{array}{l}\text { Região } \\
\text { Administrativa }\end{array}$ & Alagamento & Enxurrada & Erosão & Granizo & Movimento de Massa & Vendaval & Total \\
\hline $\begin{array}{l}\text { Plano Piloto } \\
\text { (RA I) }\end{array}$ & 14 & 3 & 0 & 0 & 0 & 2 & 19 \\
\hline Gama (RA II) & 1 & 0 & 1 & 0 & 0 & 1 & 3 \\
\hline $\begin{array}{l}\text { Taguatinga (RA } \\
\text { III) }\end{array}$ & 3 & 1 & 1 & 0 & 0 & 0 & 5 \\
\hline $\begin{array}{l}\text { Brazlândia (RA } \\
\text { IV) }\end{array}$ & 0 & 0 & 0 & 0 & 0 & 0 & 0 \\
\hline $\begin{array}{l}\text { Sobradinho (RA } \\
\text { V) }\end{array}$ & 4 & 1 & 1 & 0 & 0 & 1 & 7 \\
\hline $\begin{array}{l}\text { Planaltina (RA } \\
\text { VI) }\end{array}$ & 3 & 0 & 1 & 0 & 0 & 1 & 5 \\
\hline $\begin{array}{l}\text { Paranoá (RA } \\
\text { VII) }\end{array}$ & 3 & 2 & 0 & 0 & 0 & 1 & 6 \\
\hline $\begin{array}{l}\text { Núcleo } \\
\text { Bandeirante } \\
\text { (RA VIII) }\end{array}$ & 2 & 1 & 1 & 0 & 0 & 1 & 5 \\
\hline $\begin{array}{l}\text { Ceilândia (RA } \\
\text { IX) }\end{array}$ & 4 & 2 & 3 & 0 & 0 & 1 & 10 \\
\hline Guará (RA X) & 3 & 0 & 0 & 0 & 0 & 2 & 5 \\
\hline Cruzeiro (RA XI) & 1 & 0 & 0 & 0 & 0 & 0 & 1 \\
\hline Samambaia (RA & 3 & 2 & 0 & 0 & 0 & 1 & 6 \\
\hline
\end{tabular}




\begin{tabular}{|c|c|c|c|c|c|c|c|}
\hline XII) & & & & & & & \\
\hline $\begin{array}{l}\text { Santa Maria } \\
\text { (RA XIII) }\end{array}$ & 0 & 0 & 0 & 0 & 0 & 0 & 0 \\
\hline $\begin{array}{l}\text { São Sebastião } \\
\text { (RA XIV) }\end{array}$ & 1 & 1 & 1 & 0 & 0 & 2 & 5 \\
\hline $\begin{array}{l}\text { Recanto das } \\
\text { Emas (RA XV) }\end{array}$ & 0 & 0 & 0 & 1 & 0 & 1 & 2 \\
\hline $\begin{array}{l}\text { Lago Sul (RA } \\
\text { XVI) }\end{array}$ & 2 & 0 & 0 & 0 & 0 & 1 & 3 \\
\hline $\begin{array}{l}\text { Riacho Fundo } \\
\text { (RA XVII) }\end{array}$ & 2 & 0 & 0 & 0 & 0 & 0 & 2 \\
\hline $\begin{array}{l}\text { Lago Norte (RA } \\
\text { XVIII) }\end{array}$ & 1 & 1 & 0 & 0 & 0 & 1 & 3 \\
\hline $\begin{array}{l}\text { Candangolândia } \\
\text { (RA XIX) }\end{array}$ & 0 & 0 & 0 & 0 & 0 & 0 & 0 \\
\hline $\begin{array}{l}\text { Águas Claras } \\
\text { (RA XX) }\end{array}$ & 0 & 0 & 0 & 0 & 0 & 0 & 0 \\
\hline $\begin{array}{l}\text { Riacho Fundo II } \\
\text { (RA XXI) }\end{array}$ & 0 & 0 & 0 & 0 & 0 & 1 & 1 \\
\hline $\begin{array}{l}\text { Sudoeste / } \\
\text { Octogonal (RA } \\
\text { XXII) }\end{array}$ & 0 & 0 & 0 & 0 & 0 & 0 & 0 \\
\hline $\begin{array}{l}\text { Varjão (RA } \\
\text { XXIII) }\end{array}$ & 4 & 2 & 2 & 0 & 0 & 0 & 8 \\
\hline $\begin{array}{l}\text { Park Way (RA } \\
\text { XXIV) }\end{array}$ & 1 & 0 & 0 & 0 & 0 & 0 & 1 \\
\hline $\begin{array}{l}\text { Setor } \\
\text { Complementar } \\
\text { de Indústria e } \\
\text { Abastecimento } \\
\text { (RA XXV) }\end{array}$ & 3 & 1 & 0 & 0 & 0 & 1 & 5 \\
\hline $\begin{array}{l}\text { Sobradinho II } \\
\text { (RA XXVI) }\end{array}$ & 0 & 0 & 0 & 0 & 0 & 0 & 0 \\
\hline $\begin{array}{l}\text { Jardim Botânico } \\
\text { (RA XXVII) }\end{array}$ & 1 & 0 & 0 & 0 & 0 & 0 & 1 \\
\hline $\begin{array}{l}\text { Itapoã (RA } \\
\text { XXVII) }\end{array}$ & 4 & 2 & 1 & 0 & 0 & 0 & 7 \\
\hline $\begin{array}{l}\text { Setor de } \\
\text { Indústria e } \\
\text { Abastecimento } \\
\text { (RA XXIX) }\end{array}$ & 1 & 0 & 0 & 0 & 0 & 0 & 1 \\
\hline $\begin{array}{l}\text { Vicente Pires } \\
\text { (RA XXX) }\end{array}$ & 1 & 3 & 0 & 0 & 0 & 0 & 4 \\
\hline Fercal (RA XXXI) & 0 & 2 & 0 & 0 & 0 & 0 & 2 \\
\hline Total & 62 & 24 & 12 & 1 & 0 & 18 & 117 \\
\hline
\end{tabular}

Quadro 8. Número de reportagens encontradas mensalmente em 2006 com tipologia de desastres naturais. Elaborado pelo autor.

Em relação à tipologia de desastres naturais, os alagamentos foram os desastres naturais que ocorreram com maior frequência, sendo observados 62 vezes nas Regiões Administrativas; seguidos por enxurradas, com 24 ocorrências; vendavais, com 18 ocorrências; erosão, com 12 ocorrências; e 
queda de granizo, com uma ocorrência. As porcentagens de cada tipo de desastres podem ser observadas no Gráfico 35.

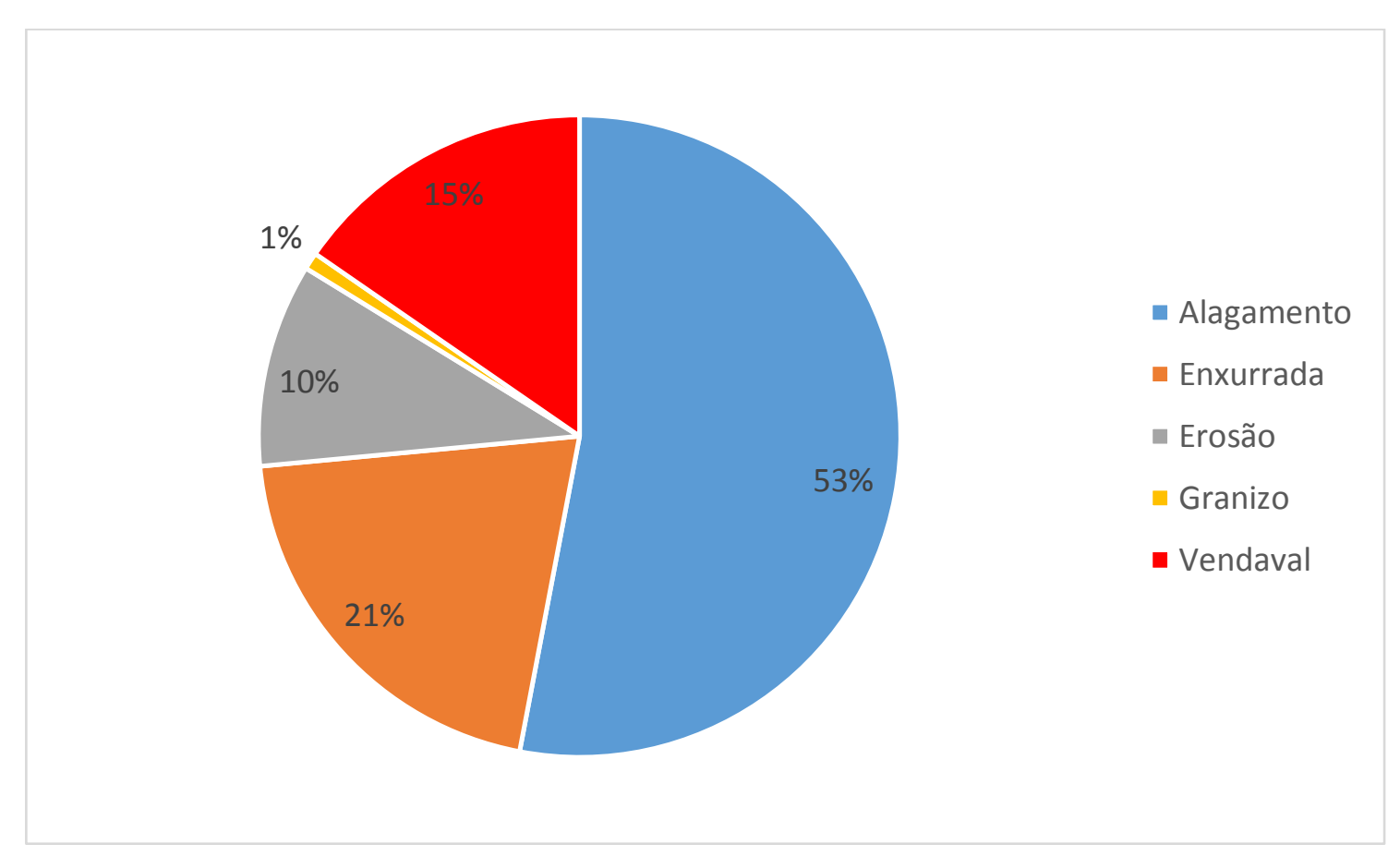

Gráfico 35. Porcentagem de desastres naturais encontrados nas reportagens ocorridos em 2006. Elaborado pelo autor.

$O$ ano de 2006 foi aquele que apresentou a maior quantidade de notícias. Três se destacam. A primeira, no mês de fevereiro, mostra como a construção civil é um dos principais agentes catalisadores do aumento dos riscos e vulnerabilidades de desastres naturais no DF, sobretudo com relação às erosões.

A segunda mostra como uma forte e rápida precipitação ocorrido em março alagou diversos pontos do DF rapidamente, paralisando o trânsito. A reportagem também chama atenção para o volume acumulado de precipitação no início do mês, que já havia ultrapassado a média da Normal Climatológica.

A terceira reportagem sintetiza o ocorrido no mês de outubro, que foi o outubro mais chuvoso em 43 anos. O volume acumulado facilitou a ocorrência de diversos desastres. 


\section{MEIO AMBIENTE}

Um terço das erosões é provocado pela retirada de material usado em edificações. Problema aumenta no período de chuvas, pois terrenos danificados não conseguem absorver a água, que escorre e faz estragos

\section{Construção civil, a maior vilã}

D.

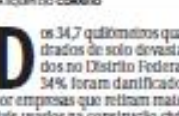

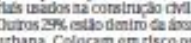

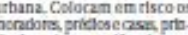

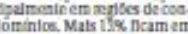

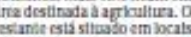
scupadss por carrado nattio

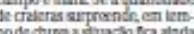

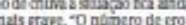

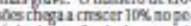

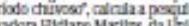

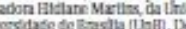

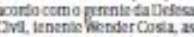
ocmacoes prosoypan in

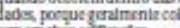
camenirtionerinaples Cosia captica que hí zir

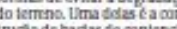
ugadede barlas de mileb

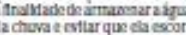
1. Dutro moranlimo consist tono, cocono slo chamados to coriss do solo para amociocer i. ADelsa CoM niertan gun. do uma cralanamrapa atima

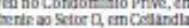

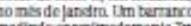

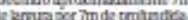

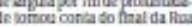

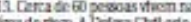

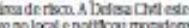
Aa virihang solme opelyp pe.

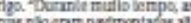

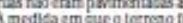
mpernowillinads, a chuwa co-

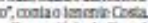
Osxcriariode Coombata

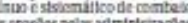
Glenzts Wo parindo de sca.

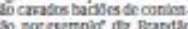

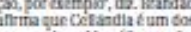

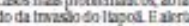

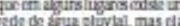

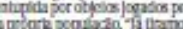

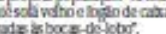

Processonatural

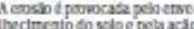

de agenirs naturals, como as

Chyrase os rutitos. 6 tomem

Deataltare cuser o 0 lemno sry

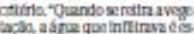

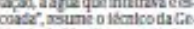
gencla de Montisramento Am bimenal da Seccotiaria de Melo

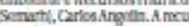

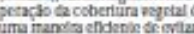

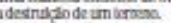
Angelin lember que aum

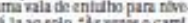
de terniz) Ecohritit con vepecia.

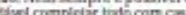
alto" ensina onspe Masbaummio enturato ser impectun Amenss qux se

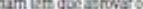
fen conler a érosia, tilto po

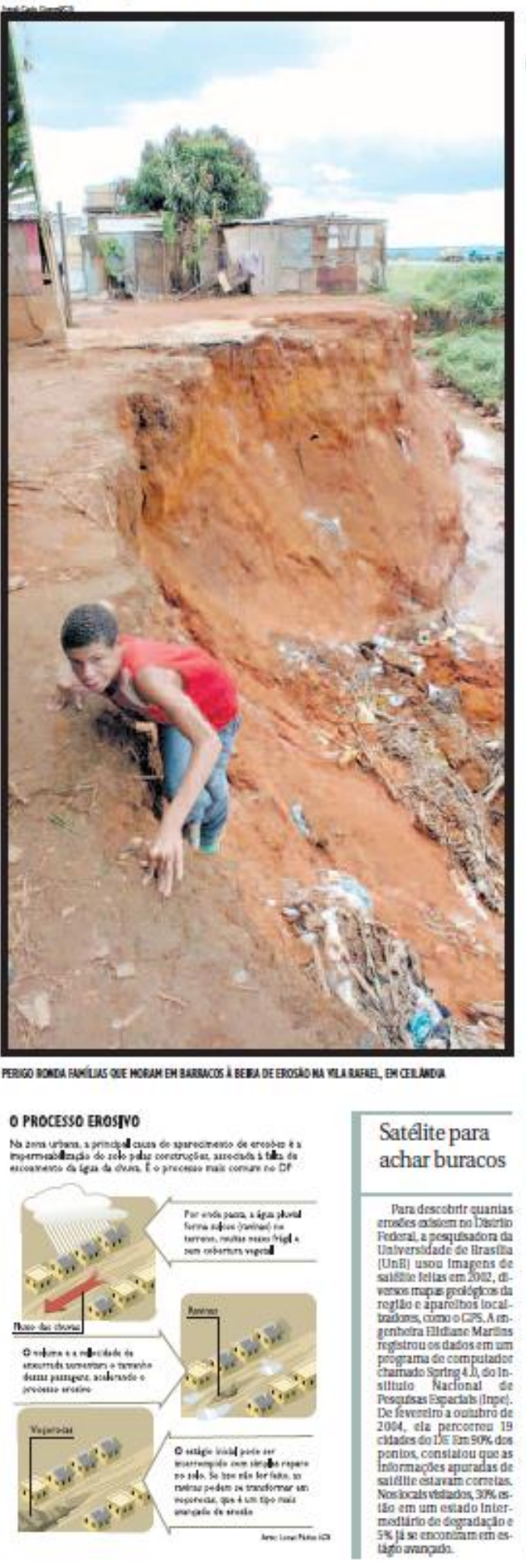

\section{DESGASTE POR TODO LADO}

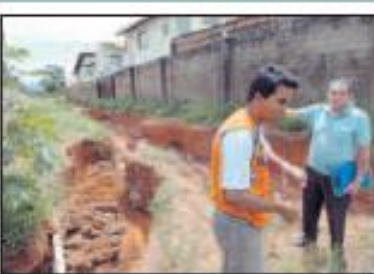

OUADEchey

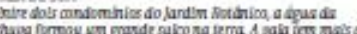

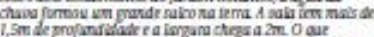

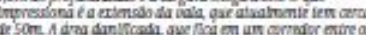

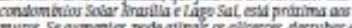

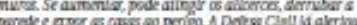

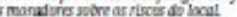

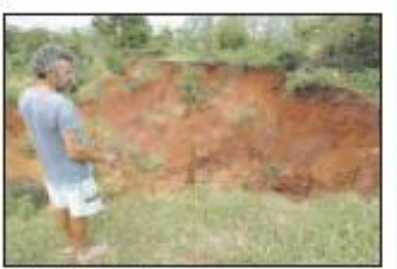

Purnagh ne carn

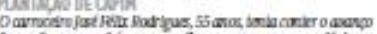

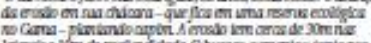

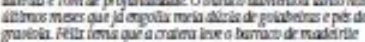
con

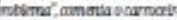

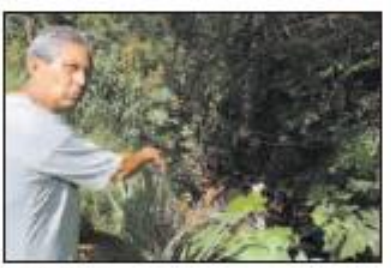

ACOS DEAMEH

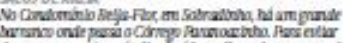

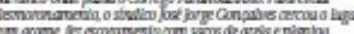

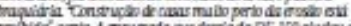

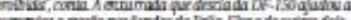

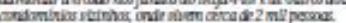

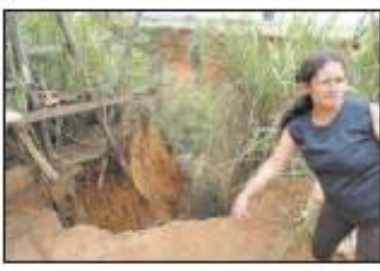

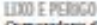

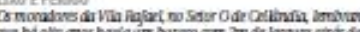

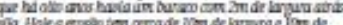

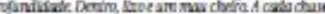

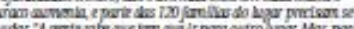

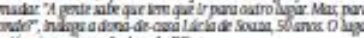

Figura 20. Recorte de reportagem de fevereiro de 2006 (Apêndice VII, Notícia № 11). Fonte: Correio Braziliense. 


\section{CLIMA}

Trânsito caótico, ruas, comércios e prédios residenciais alagados em Brasilia e Itapoã. Esse foi o saldo de uma tarde inteira de chuva forte. Transtornos devem se repetir hoje: previsão é de tempo fechado

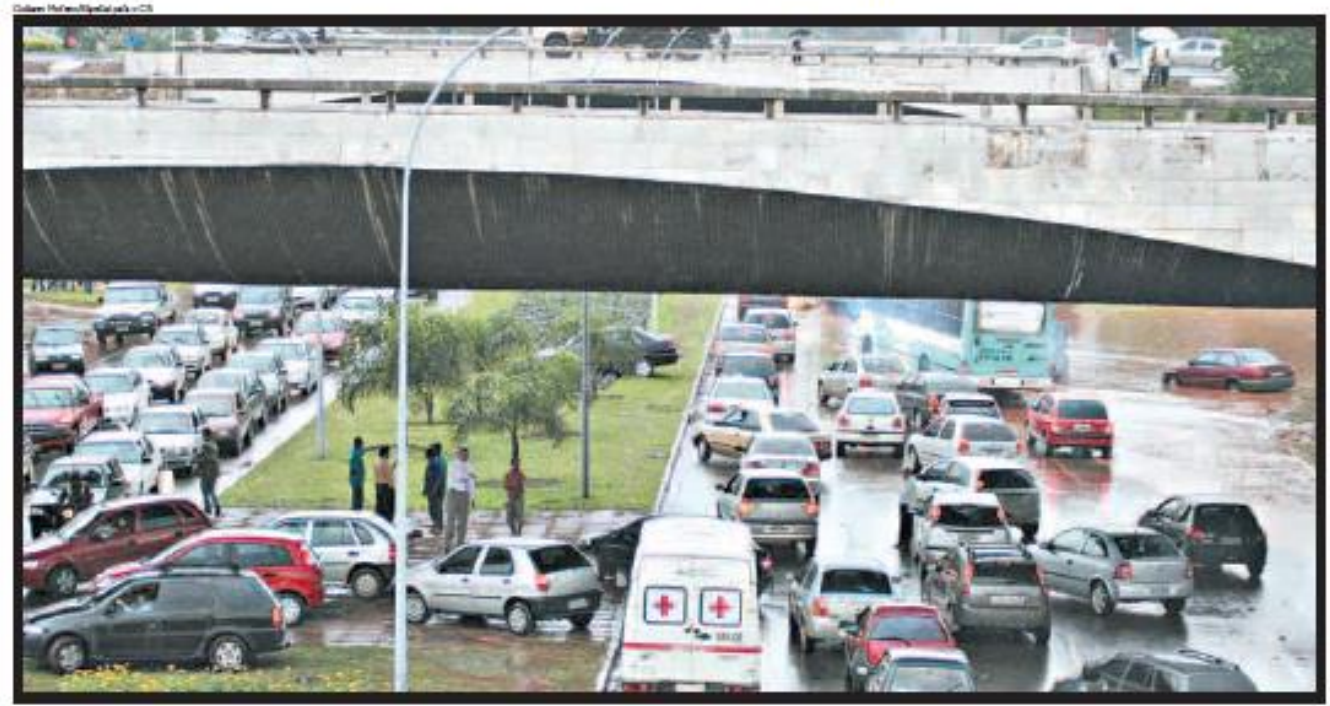

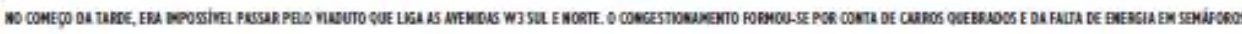

\section{Temporal assusta brasilienses}

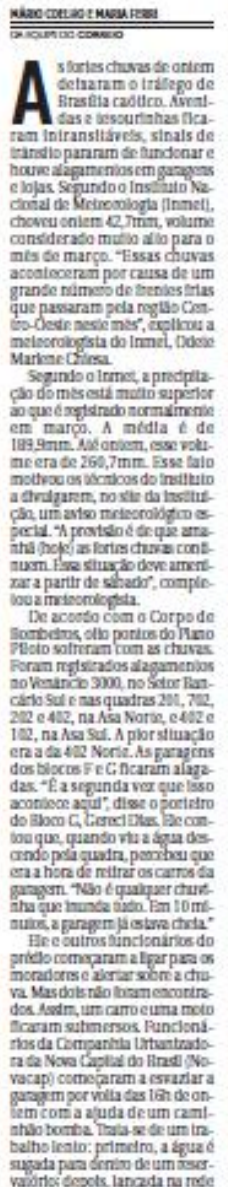

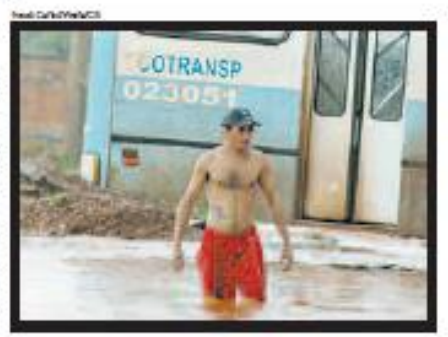

DMA DE PEDESTHE

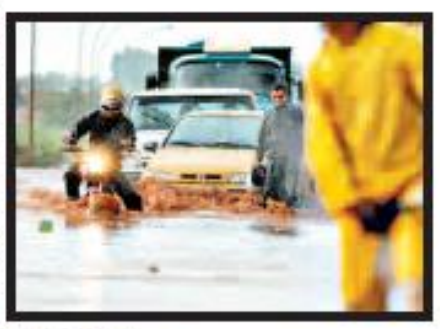

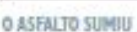

OASEDUTO SUMIU

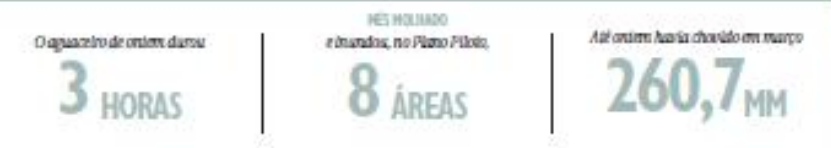

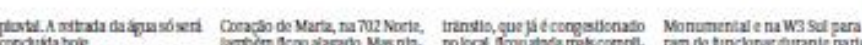
rondilathof

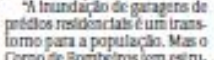

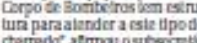

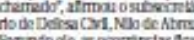

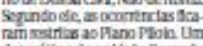

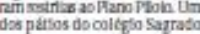

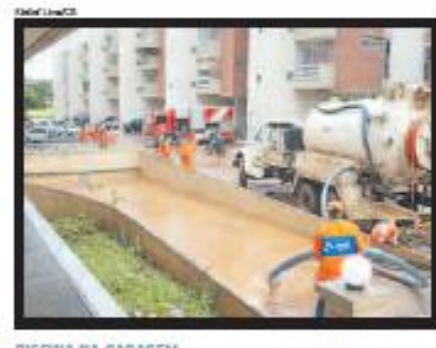

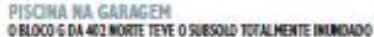

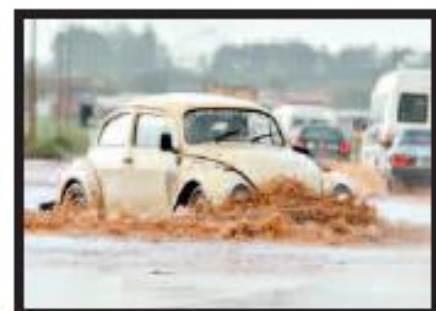

CENA RECORREUT

GeVA RECornante

ckidentes

Minde depar a a duar poniss de

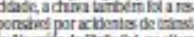

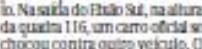

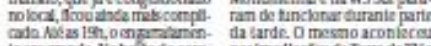

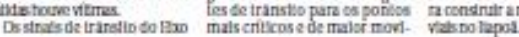

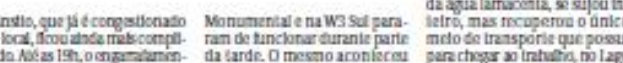

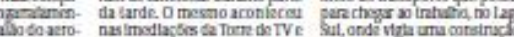

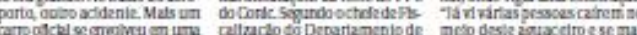

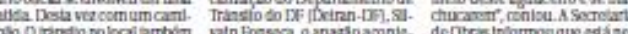

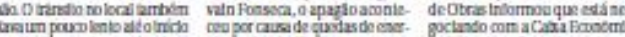

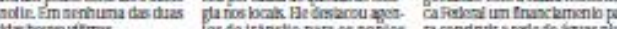

Figura 21. Recorte de reportagem de março de 2006 (Apêndice VII, Notícia № 16). Fonte: Correio Braziliense. 


\section{$25 \operatorname{CIDADES} \approx 0$}

TEMPO

Em 43 anos, nunca choveu tanto na capital neste mês. O temporal de ontem provocou alagamentos e congestionamentos nas principais vias do DF. No Riacho Fundo, 17 famílias ficaram desabrigadas
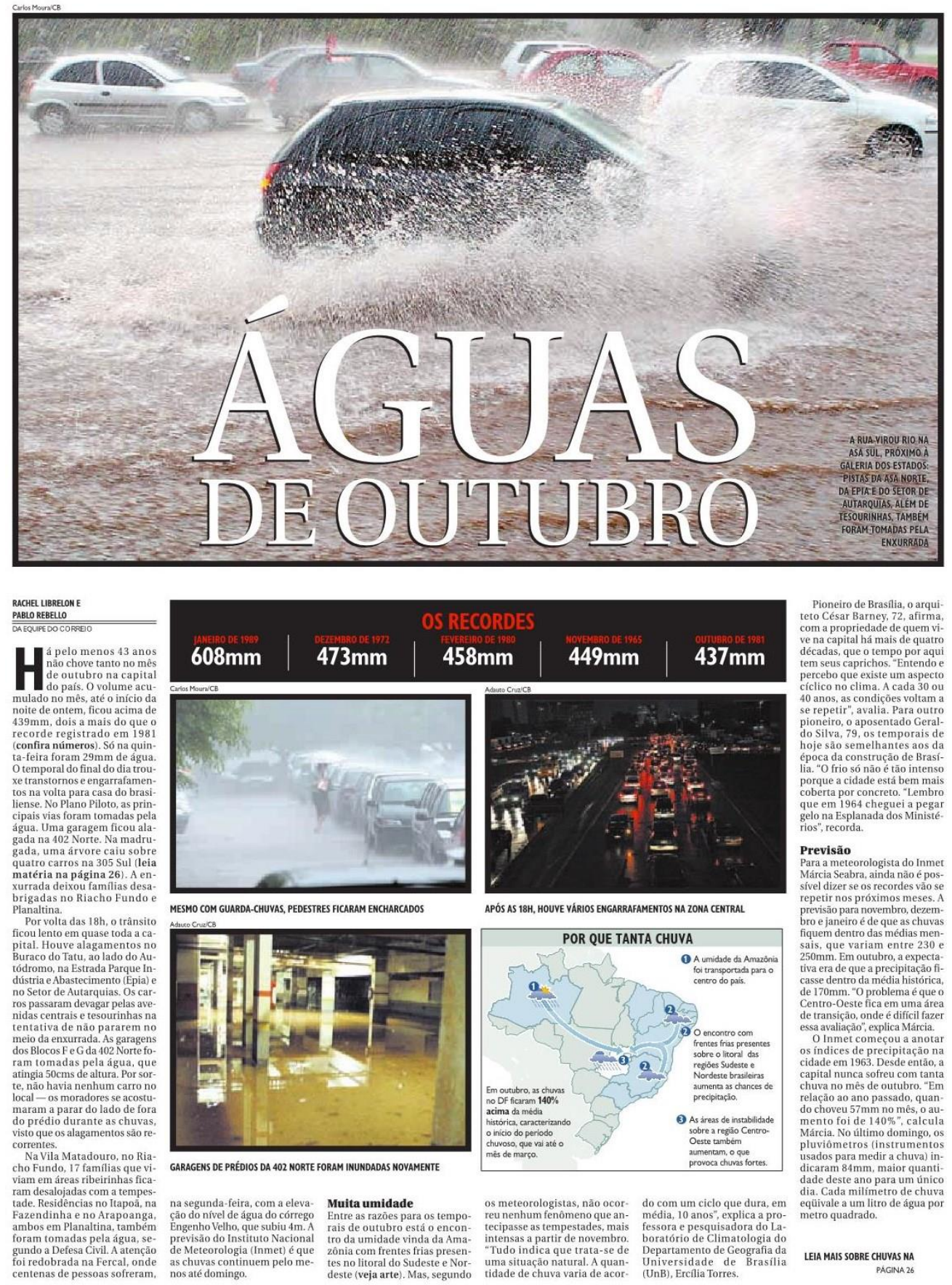

Figura 22. Recorte de reportagem de outubro de 2006 (Apêndice VII, Notícia no 26). Fonte: Correio Braziliense. 


\subsubsection{Ano de 2007}

O ano de 2007 foi um ano pouco chuvoso. A Estação Brasília do INMET registrou um total de precipitação acumulada anualmente de $1167 \mathrm{~mm}$ de chuva (Gráfico 36), aproximadamente $25 \%$ abaixo da média de precipitação anual da Normal Climatológica e a Estação Roncador do INMET registrou 1203,7 mm, cerca de 22\% abaixo da média histórica, que é de 1540,6 mm (Gráfico 37).

Na Estação Brasília, as chuvas só superaram a média da Normal nos meses de janeiro, fevereiro e dezembro. Na Estação Roncador, as chuvas superaram a média em janeiro e dezembro, ficando abaixo em todo o restante do ano.

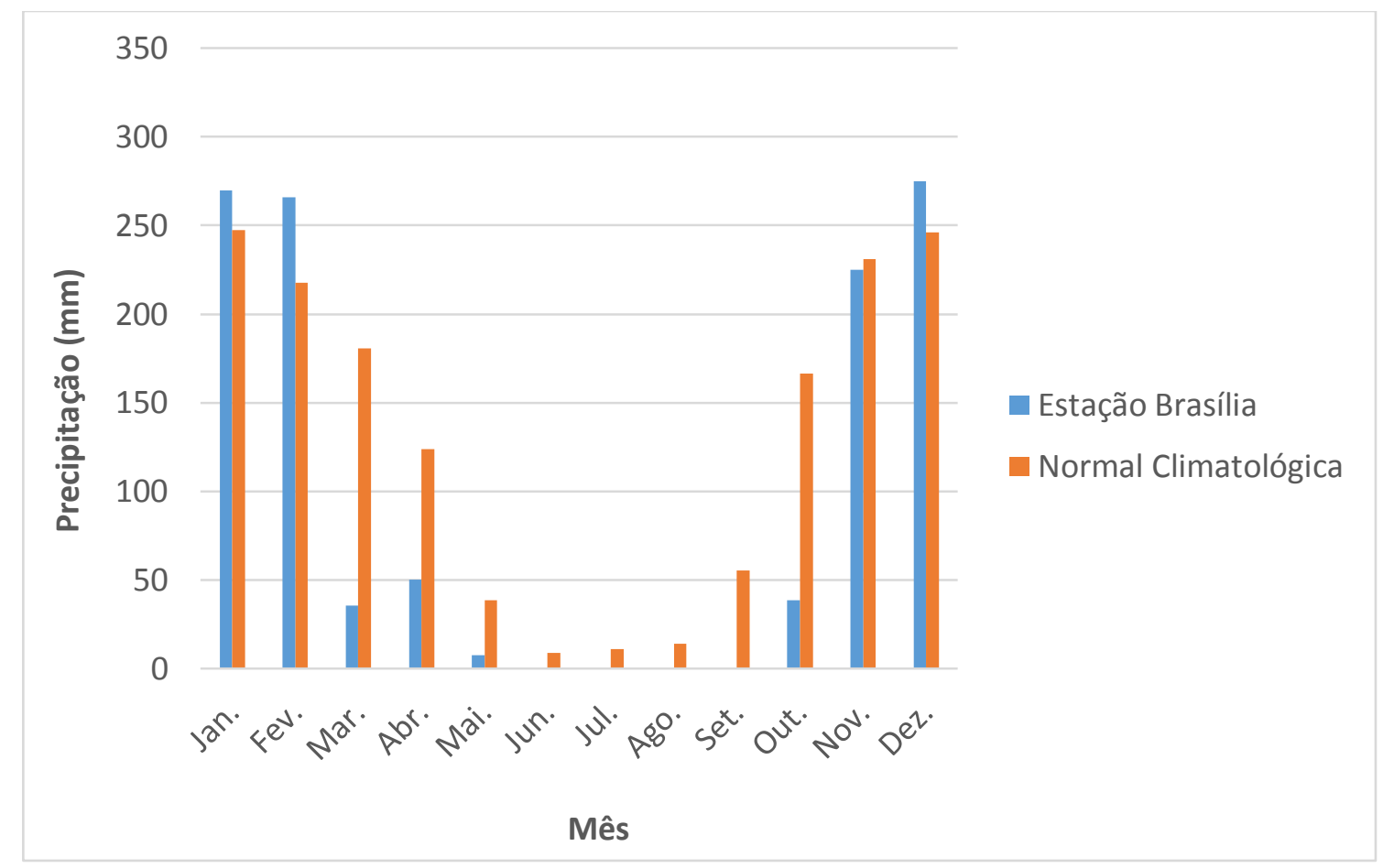

Gráfico 36. Precipitação mensal acumulada em 2007 na Estação Brasília do INMET (DF). 


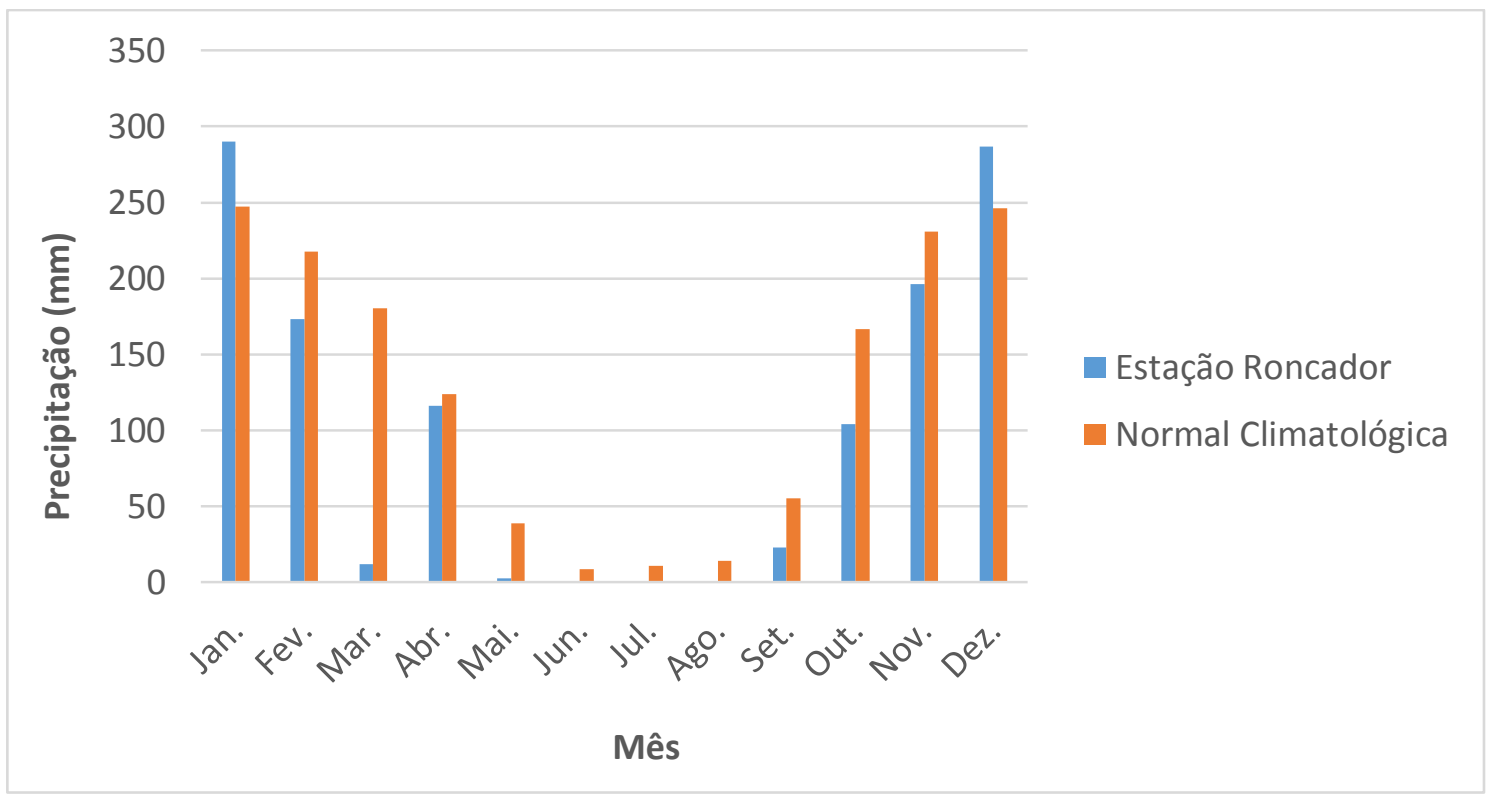

Gráfico 37. Precipitação mensal acumulada em 2007 na Estação Roncador do INMET (DF).

Mesmo sendo um ano com baixo volume de precipitação acumulada, em 2007 foram encontradas 24 reportagens referentes à desastres naturais associados às precipitações, em janeiro, fevereiro, março, outubro, novembro e dezembro, como pode ser aferido no Gráfico 38 e no Apêndice VIII. Esse fato é um indício de que mesmo as taxas pluviométricas mensais apresentando valores inferiores à Normal, as chuvas foram intensas e concentradas para o ano, sobretudo devido à longa estação seca.

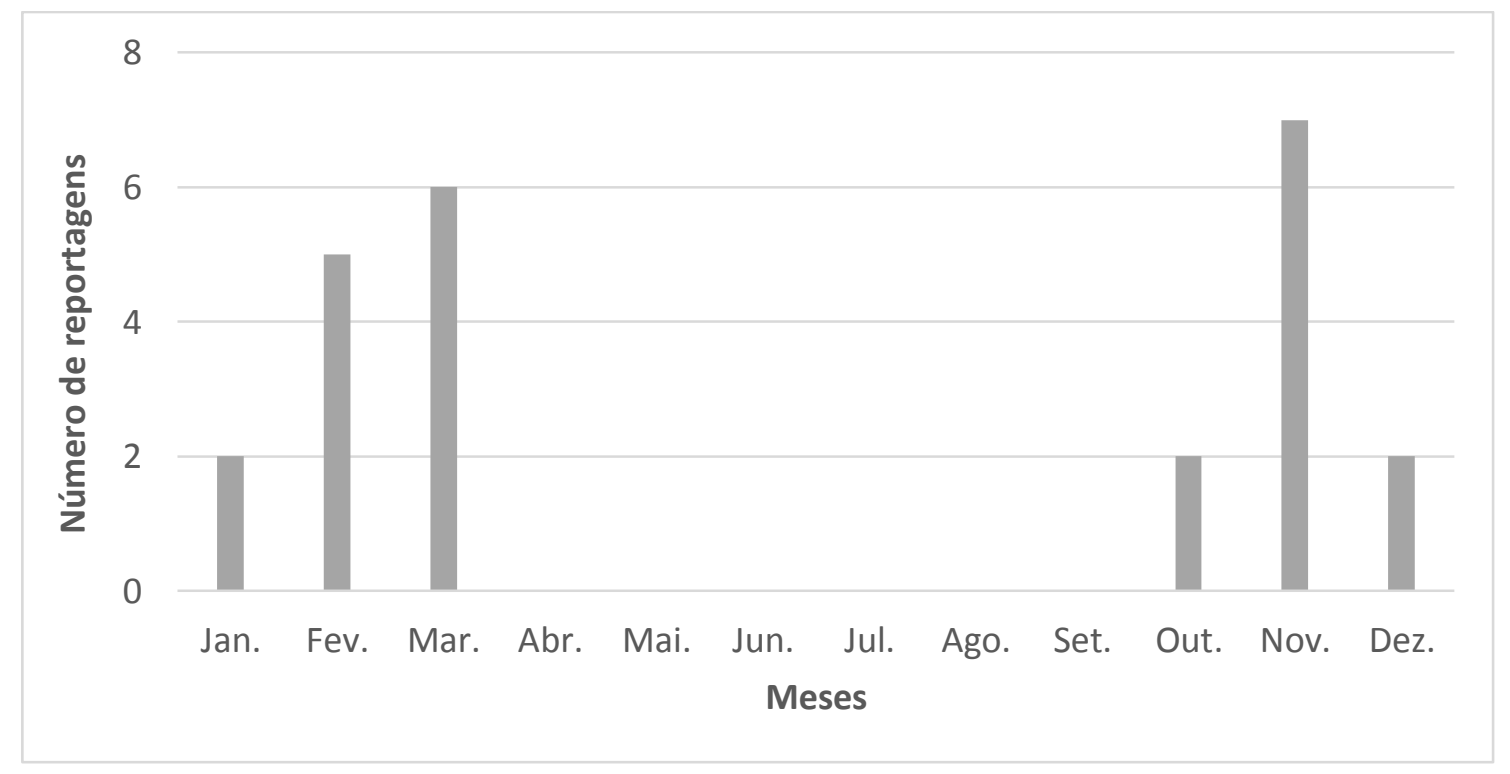

Gráfico 38. Número de reportagens encontradas mensalmente em 2007. Fonte dos dados: Correio Braziliense. Elaborado pelo autor. 
De acordo com o que foi registrado nas reportagens, as Regiões Administrativas mais afetadas foram o Plano Piloto (RA I), com 17 ocorrências de desastres, Ceilândia (RA IX), com 5 ocorrências e Guará com 3 ocorrências.

\begin{tabular}{|c|c|c|c|c|c|c|c|}
\hline $\begin{array}{l}\text { Região } \\
\text { Administrativa }\end{array}$ & Alagamento & Enxurrada & Erosão & Granizo & $\begin{array}{l}\text { Movimento } \\
\text { de Massa }\end{array}$ & Vendaval & Total \\
\hline $\begin{array}{l}\text { Plano Piloto } \\
\text { (RA I) }\end{array}$ & 10 & 4 & 0 & 0 & 0 & 3 & 17 \\
\hline Gama (RA II) & 0 & 0 & 0 & 0 & 0 & 0 & 0 \\
\hline $\begin{array}{l}\text { Taguatinga (RA } \\
\text { III) }\end{array}$ & 1 & 0 & 0 & 0 & 0 & 0 & 1 \\
\hline $\begin{array}{l}\text { Brazlândia (RA } \\
\text { IV) }\end{array}$ & 0 & 0 & 1 & 1 & 0 & 0 & 2 \\
\hline $\begin{array}{l}\text { Sobradinho (RA } \\
\text { V) }\end{array}$ & 0 & 0 & 0 & 0 & 0 & 1 & 1 \\
\hline $\begin{array}{l}\text { Planaltina (RA } \\
\text { VI) }\end{array}$ & 0 & 0 & 0 & 0 & 0 & 0 & 0 \\
\hline $\begin{array}{l}\text { Paranoá (RA } \\
\text { VII) }\end{array}$ & 0 & 0 & 0 & 0 & 0 & 0 & 0 \\
\hline $\begin{array}{l}\text { Núcleo } \\
\text { Bandeirante } \\
\text { (RA VIII) }\end{array}$ & 1 & 1 & 0 & 0 & 0 & 0 & 2 \\
\hline $\begin{array}{l}\text { Ceilândia (RA } \\
\text { IX) }\end{array}$ & 3 & 2 & 0 & 0 & 0 & 0 & 5 \\
\hline Guará (RA X) & 2 & 1 & 0 & 0 & 0 & 0 & 3 \\
\hline Cruzeiro (RA XI) & 0 & 0 & 0 & 0 & 0 & 1 & 1 \\
\hline $\begin{array}{l}\text { Samambaia (RA } \\
\text { XII) }\end{array}$ & 0 & 0 & 0 & 0 & 0 & 0 & 0 \\
\hline $\begin{array}{l}\text { Santa Maria } \\
\text { (RA XIII) }\end{array}$ & 0 & 0 & 0 & 0 & 0 & 0 & 0 \\
\hline $\begin{array}{l}\text { São Sebastião } \\
\text { (RA XIV) }\end{array}$ & 0 & 0 & 0 & 1 & 0 & 1 & 2 \\
\hline $\begin{array}{l}\text { Recanto das } \\
\text { Emas (RA XV) }\end{array}$ & 1 & 0 & 0 & 0 & 0 & 0 & 1 \\
\hline $\begin{array}{l}\text { Lago Sul (RA } \\
\text { XVI) }\end{array}$ & 0 & 0 & 0 & 0 & 0 & 0 & 0 \\
\hline $\begin{array}{l}\text { Riacho Fundo } \\
\text { (RA XVII) }\end{array}$ & 0 & 0 & 0 & 0 & 0 & 0 & 0 \\
\hline $\begin{array}{l}\text { Lago Norte (RA } \\
\text { XVIII) }\end{array}$ & 0 & 0 & 0 & 0 & 0 & 0 & 0 \\
\hline $\begin{array}{l}\text { Candangolândia } \\
\text { (RA XIX) }\end{array}$ & 0 & 0 & 0 & 0 & 0 & 0 & 0 \\
\hline $\begin{array}{l}\text { Águas Claras } \\
\text { (RA XX) }\end{array}$ & 1 & 0 & 0 & 0 & 0 & 0 & 1 \\
\hline $\begin{array}{l}\text { Riacho Fundo II } \\
\text { (RA XXI) }\end{array}$ & 0 & 0 & 0 & 0 & 0 & 0 & 0 \\
\hline $\begin{array}{l}\text { Sudoeste / } \\
\text { Octogonal (RA } \\
\text { XXII) }\end{array}$ & 0 & 0 & 0 & 0 & 0 & 0 & 0 \\
\hline $\begin{array}{l}\text { Varjão (RA } \\
\text { XXIII) }\end{array}$ & 0 & 0 & 0 & 0 & 0 & 0 & 0 \\
\hline $\begin{array}{l}\text { Park Way (RA } \\
\text { XXIV) }\end{array}$ & 0 & 0 & 0 & 0 & 0 & 0 & 0 \\
\hline Setor & 1 & 0 & 0 & 0 & 0 & 0 & 1 \\
\hline
\end{tabular}




\begin{tabular}{|llllllll}
\hline $\begin{array}{l}\text { Complementar } \\
\text { de Indústria e } \\
\text { Abastecimento }\end{array}$ & & & & & & & \\
(RA XXV) \\
$\begin{array}{l}\text { Sobradinho II } \\
\text { (RA XXVI) }\end{array}$ & 0 & 0 & 0 & 0 & 0 & 0 & 0 \\
$\begin{array}{l}\text { Jardim Botânico } \\
\text { (RA XXVII) }\end{array}$ & 0 & 0 & 0 & 0 & 0 & 0 & 0 \\
Itapoã (RA & 0 & 0 & 0 & 0 & 0 & 0 & 0 \\
$\begin{array}{l}\text { XXVII) } \\
\text { Setor de }\end{array}$ & 2 & 0 & 0 & 0 & 0 & 0 & 2 \\
$\begin{array}{l}\text { Indústria e } \\
\text { Abastecimento }\end{array}$ & & 0 & & & & & \\
$\begin{array}{l}\text { (RA XXIX) } \\
\text { Vicente Pires }\end{array}$ & 0 & 0 & 0 & 0 & 0 & 0 & 0 \\
(RA XXX) & 0 & 0 & 0 & 0 & 0 & 2 & 2 \\
$\begin{array}{l}\text { Fercal (RA XXXI) } \\
\text { Total }\end{array}$ & 22 & 8 & 1 & 2 & 0 & 8 & $\mathbf{4 1}$ \\
\hline
\end{tabular}

Quadro 9. Número de reportagens encontradas mensalmente em 2007 com tipologia de desastres naturais. Elaborado pelo autor.

Em relação à tipologia de desastres naturais, os alagamentos foram os desastres naturais que ocorreram com maior frequência, sendo observados 22 vezes nas Regiões Administrativas; seguidos por enxurradas e vendavais, com 8 ocorrências; queda de granizo, com 2 ocorrências; e erosão, com uma ocorrência. As porcentagens de cada tipo de desastres podem ser observadas no Gráfico 39.

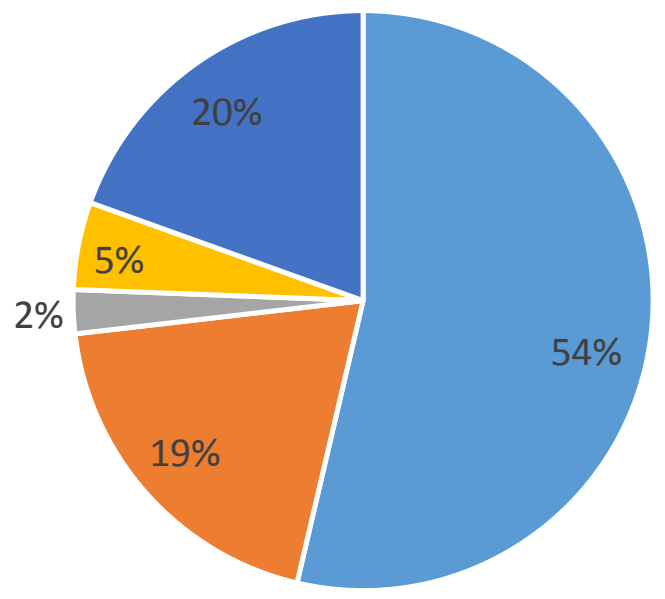

- Alagamento

- Enxurrada

- Erosão

Granizo

- Vendaval

Gráfico 39. Porcentagem de desastres naturais encontrados nas reportagens ocorridos em 2007. Elaborado pelo autor. 
No ano de 2007, há três reportagens que merecem atenção. A primeira destaca a questão de como os resíduos sólidos auxiliam no entupimento do sistema de coleta de águas pluviais e como isso consequentemente alaga as tesourinhas da Asa Norte.

A segunda mostra chuva forte, ocorrida no mês de novembro, onde a ventania de um rápido temporal destelhou um prédio comercial, que atingiu carros e pedestres. A terceira mostra um cartograma de riscos de pontos passíveis de alagamentos identificados no Plano Piloto.

\section{Temporal e lixo entopem Asa Norte}

GIZELLA RODRIGUES DA EQUIPE DO CORREIO

A empestade que desabou sobre a Asa Norte na última sexta-feira expôs uma fragilidade que deixou de ser exclusiva das áreas mais carentes do Distrito Federal. Antes restritos a regiões sem infra-estrutura, os alagamentos chegaram ao Plano Piloto e foram responsáveis por prejuízos ainda incalculáveis. O entupimento das bocas-de-lobo pelo lixo, a impermeabilização excessiva do solo, construções em áreas de nascentes, falhas de engenharia na construção das tesourinhas e a ineficiência da rede de águas pluviais são algumas das causas apontadas por especialistas para o transtorno causado pelo temporal.

No final da manhã de sextafeira choveu forte durante cerca de 40 minutos no DF. Os locais mais prejudicados foram as quadras $510 / 710,511 / 711$ e $512 / 712$ Norte. Carros foram arrastados pela Avenida W3, a água invadiu subsolos de lojas, como a Doce Encanto, a mais prejudicada. Além disso, uma tesourinha na 209 Norte ficou totalmente inundada e uma van submersa. A chuva se concentrou na Asa Norte, mas também atingiu forte Re-

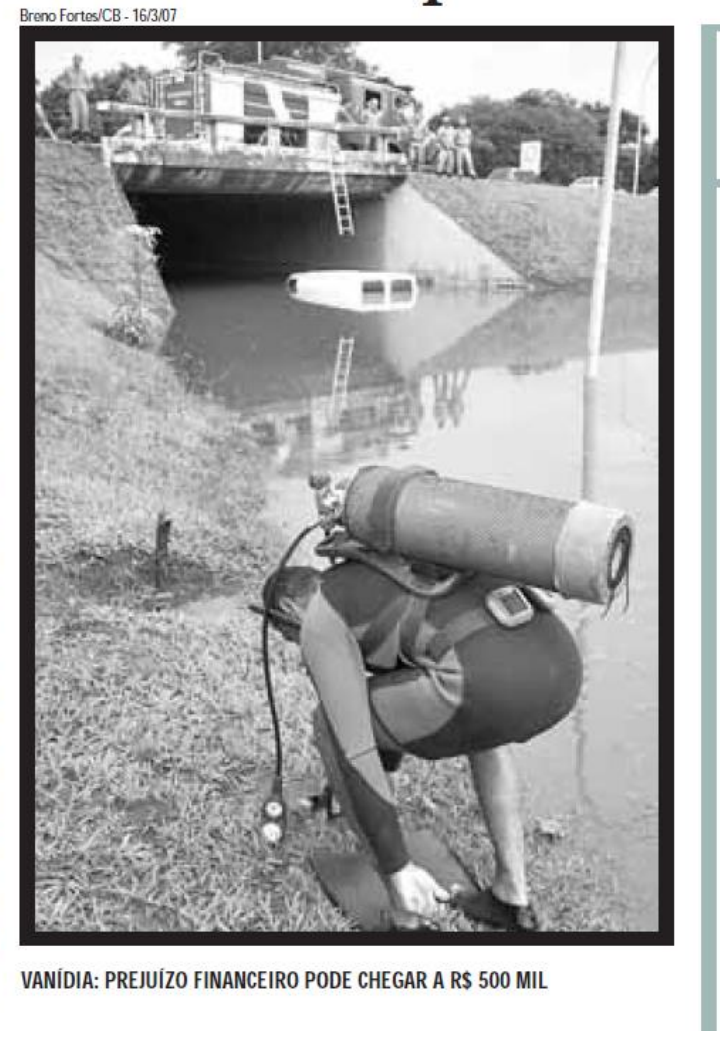

Prejuízos financeiros

Três dias após a chuva, empresários ainda tentavam limpar as lojas e recuperar o maior número de mercadorias que não foram danificadas. A realidade, porém, não era nada otimista. A água invadiu o subsolo das lojas e estragou tudo que encontrou pela frente. Na Doce Encanto, uma loja que vende móveis para quartos de bebês na 711 Norte, os proprietários estimam que $70 \%$ dos produtos ficaram imprestáveis para negó cios e calculam que os prejuízos chegam a R\$ $500 \mathrm{mil}$

Durante todo o dia, os funcionários da loja retiraram os materiais do subsolo. Dois contêineres de lixo ficaram lotados. A limpeza ainda deve durar cinco dias. Equipamentos eletrônicos, móveis, kits de almofadas para berços, máquinas de costura são exemplos do que foi perdido com a água, que subiu

Figura 23. Recorte de reportagem de março de 2007 (Apêndice VIII, Notícia no 11). Fonte: Correio Braziliense. 

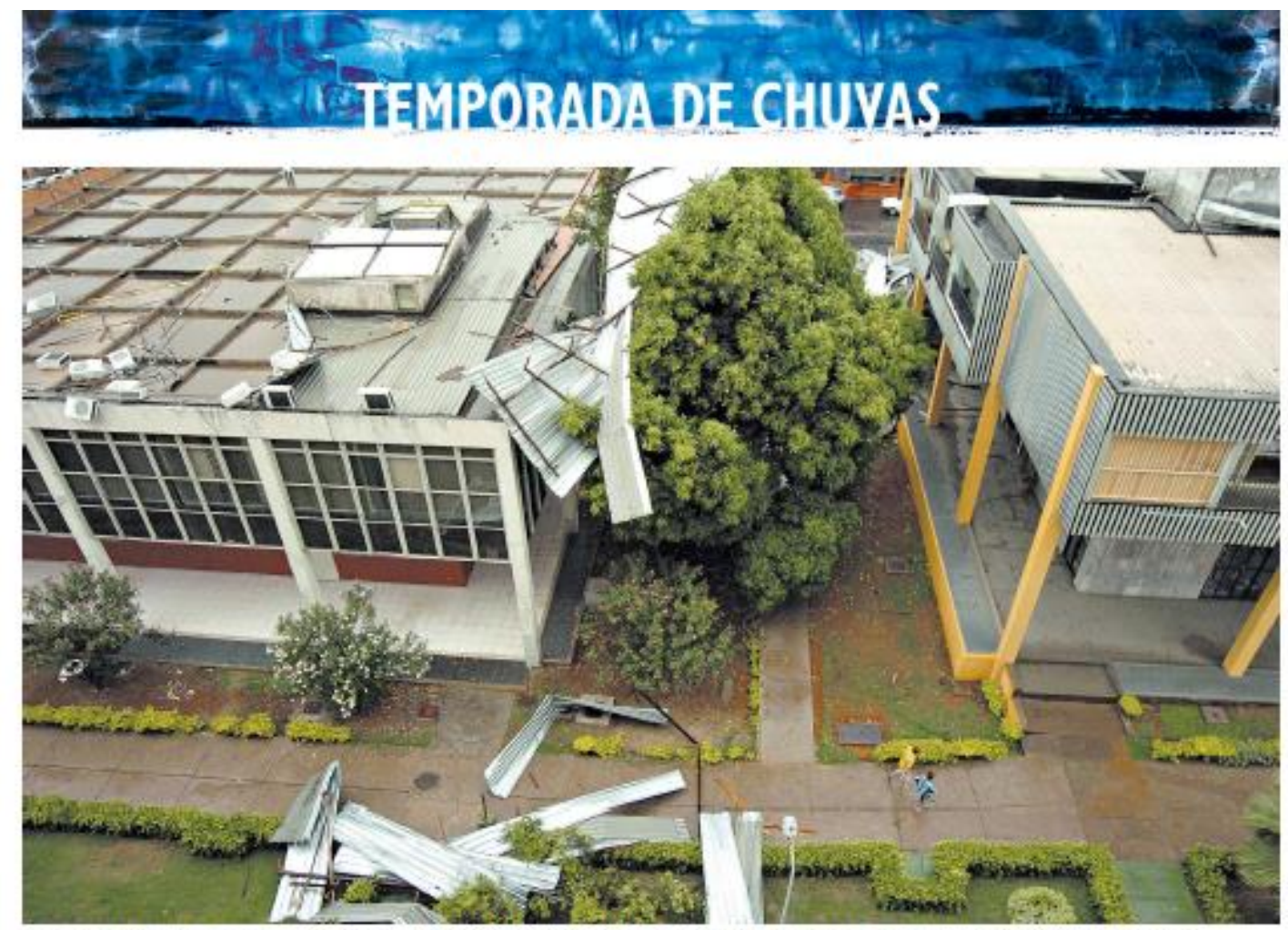

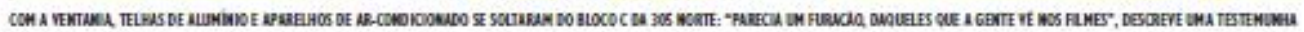

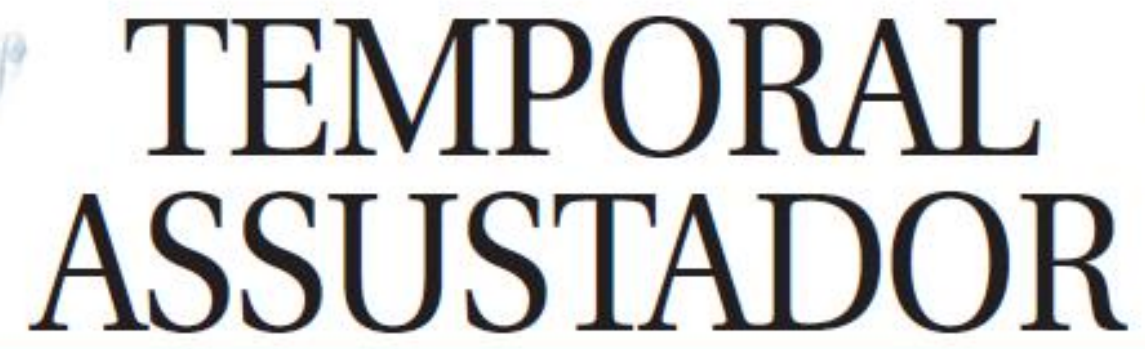

Na 305 Norte, telhado da comercial se solta e atinge oito carros. Chuva durou meia hora e alagou ruas. Meteorologia avisa que o tempo continuará fechado pelo menos até amanhã à tarde
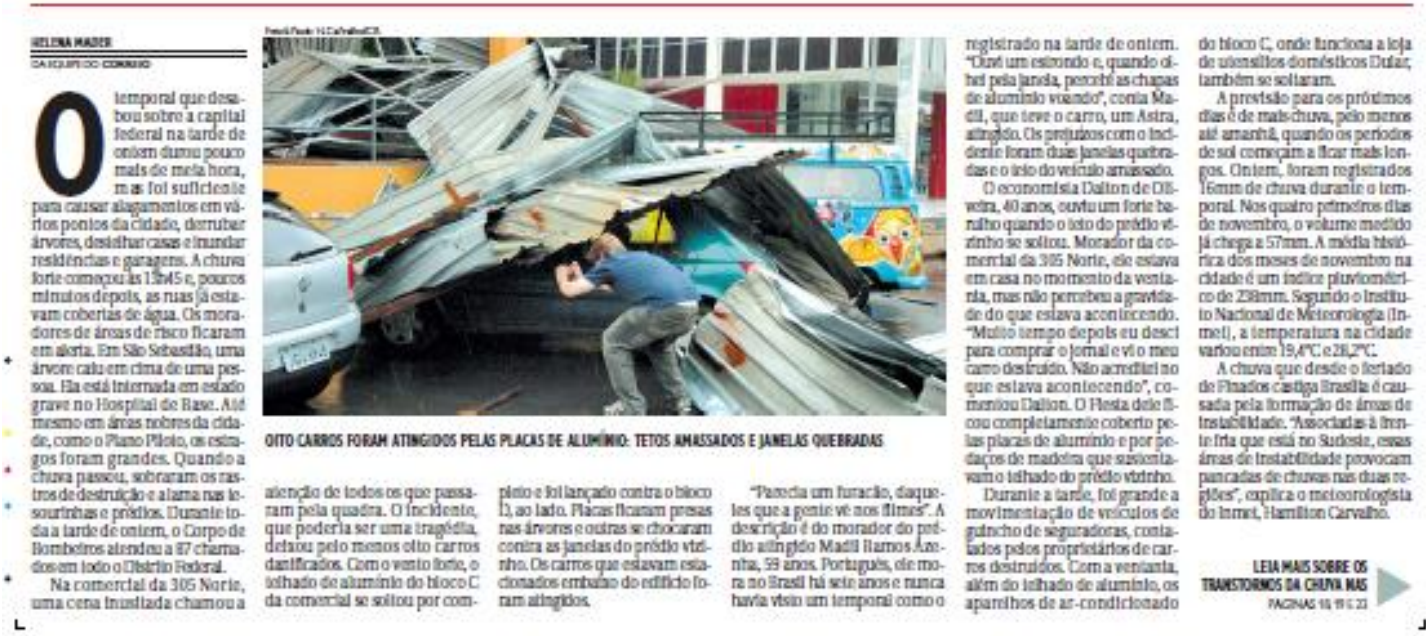

Figura 24. Recorte de reportagem de novembro de 2007 (Apêndice VIII, Notícia no 19). Fonte: Correio Braziliense. 


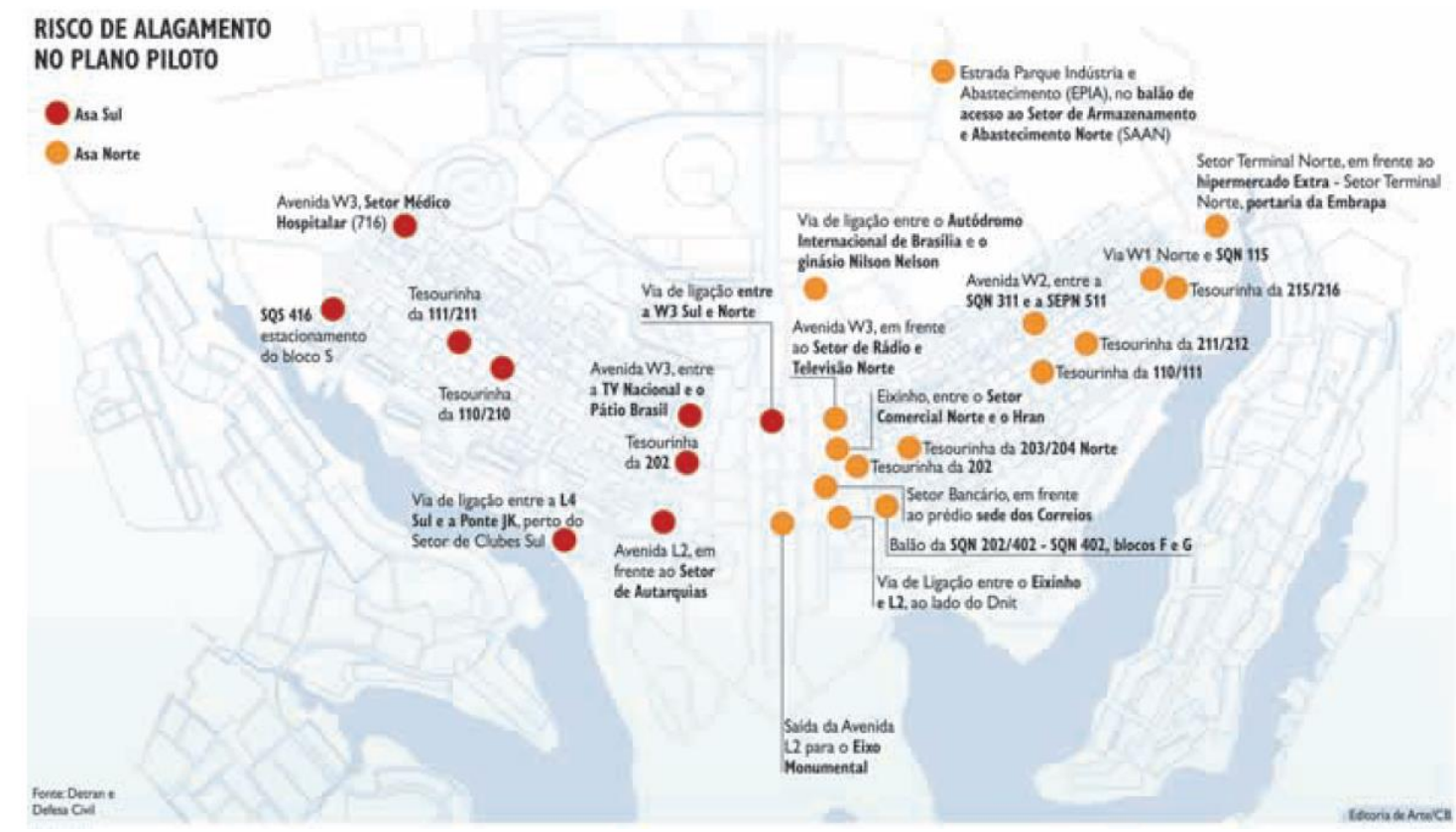

Figura 25. Recorte de reportagem de março de 2007 (Apêndice VIII, Notícia oํ 21). Fonte: Correio Braziliense.

\subsubsection{Ano de 2008}

O ano de 2008 foi um ano típico, tendo registrado na Estação Brasília do INMET registrou um total de precipitação acumulada anualmente de 1589,1 $\mathrm{mm}$ de chuva (Gráfico 40), aproximadamente 3\% acima da média de precipitação anual da Normal Climatológica e a Estação Roncador do INMET registrou 1613,7 mm, cerca de 4\% acima da média histórica, que é de 1540,6 mm (Gráfico 41).

Na primeira etapa do período chuvoso no ano, que vai de janeiro em abril, as precipitações foram regulares, tendo superado a média histórica em todos os meses, à exceção do mês de janeiro na Estação Brasília. Na segunda etapa, que vai dos meses de setembro a dezembro, as chuvas foram irregulares nas duas estações. Na Estação Brasília a chuva superou a média histórica nos meses de setembro, novembro e dezembro. Na Estação Roncador, a chuva superou a média apenas em dezembro. 


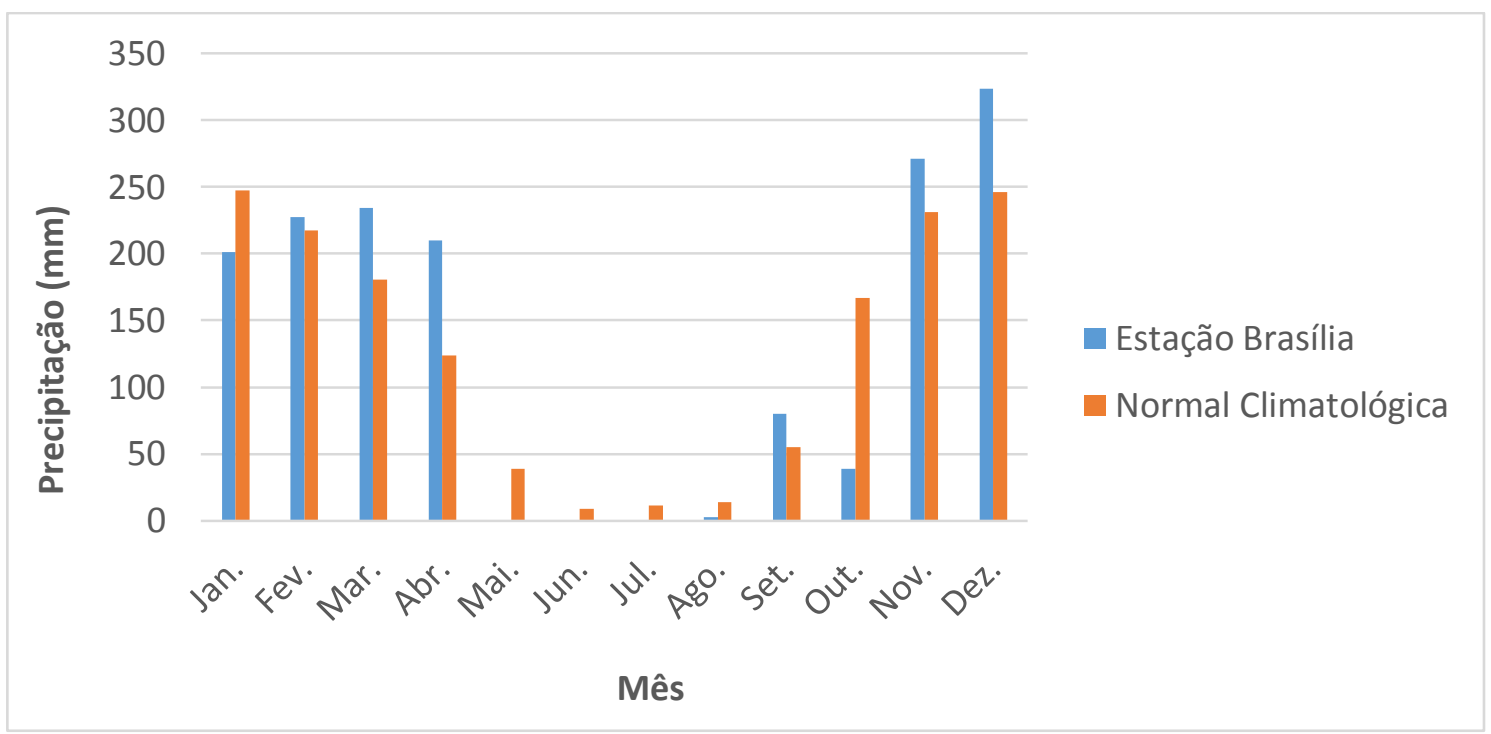

Gráfico 40. Precipitação mensal acumulada em 2008 na Estação Brasília do INMET (DF).

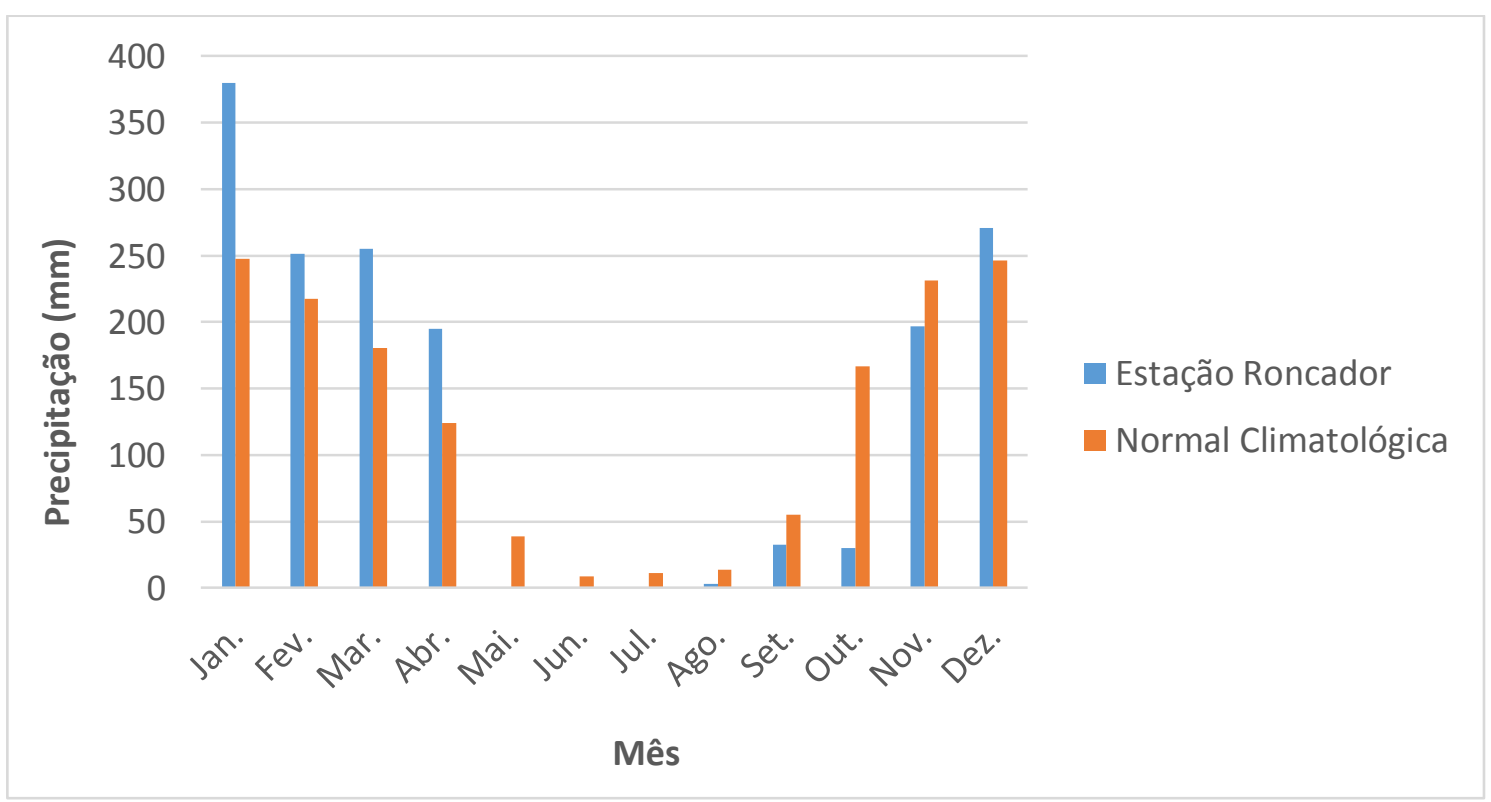

Gráfico 41. Precipitação mensal acumulada em 2008 na Estação Roncador do INMET (DF).

Em 2008 foram encontradas 26 reportagens referentes à desastres naturais associados às precipitações, em janeiro, fevereiro, março, abril, outubro e novembro, como pode ser aferido no Gráfico 42 e no Apêndice IX. O mês de fevereiro apresentou teve o maior número de reportagens (10), seguido por novembro, com 7 reportagens. 


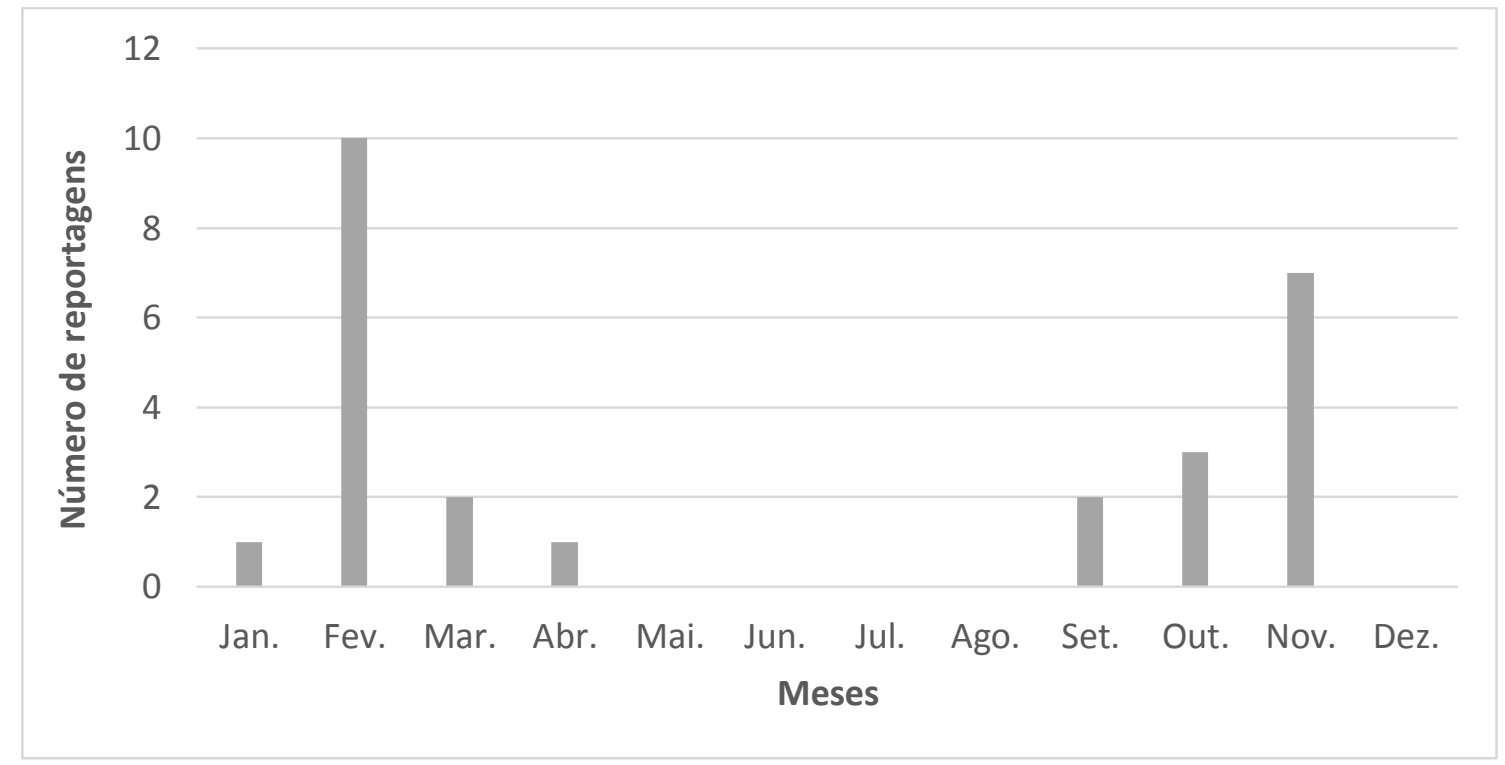

Gráfico 42. Número de reportagens encontradas mensalmente em 2008. Fonte dos dados: Correio Braziliense. Elaborado pelo autor.

De acordo com o que foi registrado nas reportagens, as Regiões Administrativas mais afetadas foram o Plano Piloto (RA I), com 17 ocorrências de desastres; Taguatinga, com 9 ocorrências; Ceilândia (RA IX), com 7 ocorrências e SCIA (RA XXV) com 5 ocorrências.

\begin{tabular}{|c|c|c|c|c|c|c|c|}
\hline $\begin{array}{l}\text { Região } \\
\text { Administrativa }\end{array}$ & Alagamento & Enxurrada & Erosão & Granizo & $\begin{array}{l}\text { Movimento } \\
\text { de Massa }\end{array}$ & Vendaval & Total \\
\hline $\begin{array}{l}\text { Plano Piloto } \\
\text { (RA I) }\end{array}$ & 9 & 2 & 0 & 2 & 0 & 4 & 17 \\
\hline Gama (RA II) & 1 & 0 & 0 & 1 & 0 & 2 & 4 \\
\hline $\begin{array}{l}\text { Taguatinga (RA } \\
\text { III) }\end{array}$ & 6 & 1 & 0 & 0 & 0 & 2 & 9 \\
\hline $\begin{array}{l}\text { Brazlândia (RA } \\
\text { IV) }\end{array}$ & 0 & 0 & 0 & 0 & 0 & 0 & 0 \\
\hline $\begin{array}{l}\text { Sobradinho (RA } \\
\text { V) }\end{array}$ & 1 & 0 & 0 & 1 & 0 & 1 & 3 \\
\hline $\begin{array}{l}\text { Planaltina (RA } \\
\text { VI) }\end{array}$ & 0 & 1 & 0 & 0 & 0 & 0 & 1 \\
\hline $\begin{array}{l}\text { Paranoá (RA } \\
\text { VII) }\end{array}$ & 0 & 0 & 0 & 0 & 0 & 0 & 0 \\
\hline $\begin{array}{l}\text { Núcleo } \\
\text { Bandeirante } \\
\text { (RA VIII) }\end{array}$ & 2 & 0 & 0 & 0 & 0 & 0 & 2 \\
\hline $\begin{array}{l}\text { Ceilândia (RA } \\
\text { IX) }\end{array}$ & 4 & 1 & 0 & 0 & 0 & 2 & 7 \\
\hline Guará (RA X) & 2 & 1 & 0 & 0 & 0 & 0 & 3 \\
\hline Cruzeiro (RA XI) & 0 & 0 & 0 & 0 & 0 & 1 & 1 \\
\hline $\begin{array}{l}\text { Samambaia (RA } \\
\text { XII) }\end{array}$ & 1 & 0 & 0 & 0 & 0 & 2 & 3 \\
\hline
\end{tabular}




\begin{tabular}{|c|c|c|c|c|c|c|c|}
\hline $\begin{array}{l}\text { Santa Maria } \\
\text { (RA XIII) }\end{array}$ & 2 & 0 & 0 & 0 & 0 & 1 & 3 \\
\hline $\begin{array}{l}\text { São Sebastião } \\
\text { (RA XIV) }\end{array}$ & 0 & 0 & 0 & 0 & 0 & 0 & 0 \\
\hline $\begin{array}{l}\text { Recanto das } \\
\text { Emas (RA XV) }\end{array}$ & 0 & 0 & 0 & 0 & 0 & 0 & 0 \\
\hline $\begin{array}{l}\text { Lago Sul (RA } \\
\text { XVI) }\end{array}$ & 0 & 1 & 0 & 0 & 0 & 1 & 2 \\
\hline $\begin{array}{l}\text { Riacho Fundo } \\
\text { (RA XVII) }\end{array}$ & 0 & 0 & 0 & 0 & 0 & 0 & 0 \\
\hline $\begin{array}{l}\text { Lago Norte (RA } \\
\text { XVIII) }\end{array}$ & 0 & 0 & 0 & 0 & 0 & 0 & 0 \\
\hline $\begin{array}{l}\text { Candangolândia } \\
\text { (RA XIX) }\end{array}$ & 0 & 0 & 0 & 0 & 0 & 0 & 0 \\
\hline $\begin{array}{l}\text { Águas Claras } \\
\text { (RA XX) }\end{array}$ & 1 & 0 & 0 & 0 & 0 & 0 & 1 \\
\hline $\begin{array}{l}\text { Riacho Fundo II } \\
\text { (RA XXI) }\end{array}$ & 0 & 0 & 0 & 0 & 0 & 0 & 0 \\
\hline $\begin{array}{l}\text { Sudoeste / } \\
\text { Octogonal (RA } \\
\text { XXII) }\end{array}$ & 0 & 0 & 0 & 1 & 0 & 0 & 1 \\
\hline $\begin{array}{l}\text { Varjão (RA } \\
\text { XXIII) }\end{array}$ & 0 & 0 & 0 & 0 & 0 & 0 & 0 \\
\hline $\begin{array}{l}\text { Park Way (RA } \\
\text { XXIV) }\end{array}$ & 1 & 0 & 0 & 0 & 0 & 1 & 2 \\
\hline $\begin{array}{l}\text { Setor } \\
\text { Complementar } \\
\text { de Indústria e } \\
\text { Abastecimento } \\
\text { (RA XXV) }\end{array}$ & 3 & 1 & 0 & 0 & 0 & 1 & 5 \\
\hline $\begin{array}{l}\text { Sobradinho II } \\
\text { (RA XXVI) }\end{array}$ & 1 & 0 & 0 & 0 & 0 & 1 & 2 \\
\hline $\begin{array}{l}\text { Jardim Botânico } \\
\text { (RA XXVII) }\end{array}$ & 0 & 0 & 0 & 0 & 0 & 0 & 0 \\
\hline $\begin{array}{l}\text { Itapoã (RA } \\
\text { XXVII) }\end{array}$ & 0 & 0 & 0 & 0 & 0 & 0 & 0 \\
\hline $\begin{array}{l}\text { Setor de } \\
\text { Indústria e } \\
\text { Abastecimento } \\
\text { (RA XXIX) }\end{array}$ & 1 & 0 & 0 & 0 & 0 & 0 & 1 \\
\hline $\begin{array}{l}\text { Vicente Pires } \\
\text { (RA XXX) }\end{array}$ & 0 & 0 & 0 & 0 & 0 & 0 & 0 \\
\hline Fercal (RA XXXI) & 1 & 0 & 0 & 0 & 0 & 0 & 1 \\
\hline Total & 36 & 8 & 0 & 5 & 0 & 19 & 68 \\
\hline
\end{tabular}

Quadro 10. Número de reportagens encontradas mensalmente em 2008 com tipologia de desastres naturais. Elaborado pelo autor.

Em relação à tipologia de desastres naturais, os alagamentos foram os desastres naturais que ocorreram com maior frequência, sendo observados 36 vezes nas Regiões Administrativas; seguido por vendavais, com 19 
ocorrências; enxurrada, com 8 ocorrências; e queda de granizo, com 5 ocorrências. As porcentagens de cada tipo de desastres podem ser observadas no Gráfico 43.

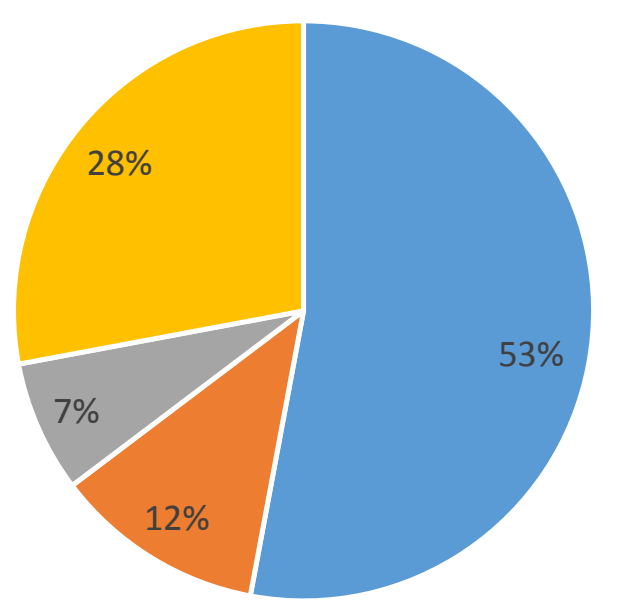

- Alagamento

- Enxurrada

- Granizo

- Vendaval

Gráfico 43. Porcentagem de desastres naturais encontrados nas reportagens ocorridos em 2008. Elaborado pelo autor.

$\mathrm{O}$ ano de 2008 traz duas reportagens como destaque. A primeira, no mês de fevereiro, mostra que as 12 horas seguidas de chuva no dia anterior deixaram um rastro de destruição pela capital: apenas nesse tempo choveu 90 $\mathrm{mm}$, mais do que os $60 \mathrm{~mm}$ registrados nos 20 primeiros dias de fevereiro. A reportagem informa que o INMET alertou que o volume não seria anormal nessa época do ano. O viaduto que liga a BR-070 à Estrutural ficou alagado. Em Taguatinga, chuva provocou estragos em uma obra, que foi interditada pela Defesa Civil, pois estava com a parede prestes a desabar. Na Ceilândia, Estrutural e Fercal, Defesa Civil pretende derrubar 284 casas em áreas de risco. A segunda mostra como uma forte e rápida precipitação ocorrido em março alagou diversos pontos do DF rapidamente, paralisando o trânsito. A reportagem também chama atenção para o volume acumulado de precipitação no início do mês, que já havia ultrapassado a média da Normal Climatológica.

A segunda reportagem novamente repete a manchete, apontando a quantidade de alagamentos que se sucederam no Plano Piloto com o aumento da precipitação. 
CLIMA

Após 12 horas de chuva forte, várias localldades do Distrito Federal apresentaram problemas. Em Riacho Fundo, famillias de chacareiros ficaram isoladas. Em Santa Marla, aulas de escola pública foram suspensas

\section{Temporal leva risco à população}
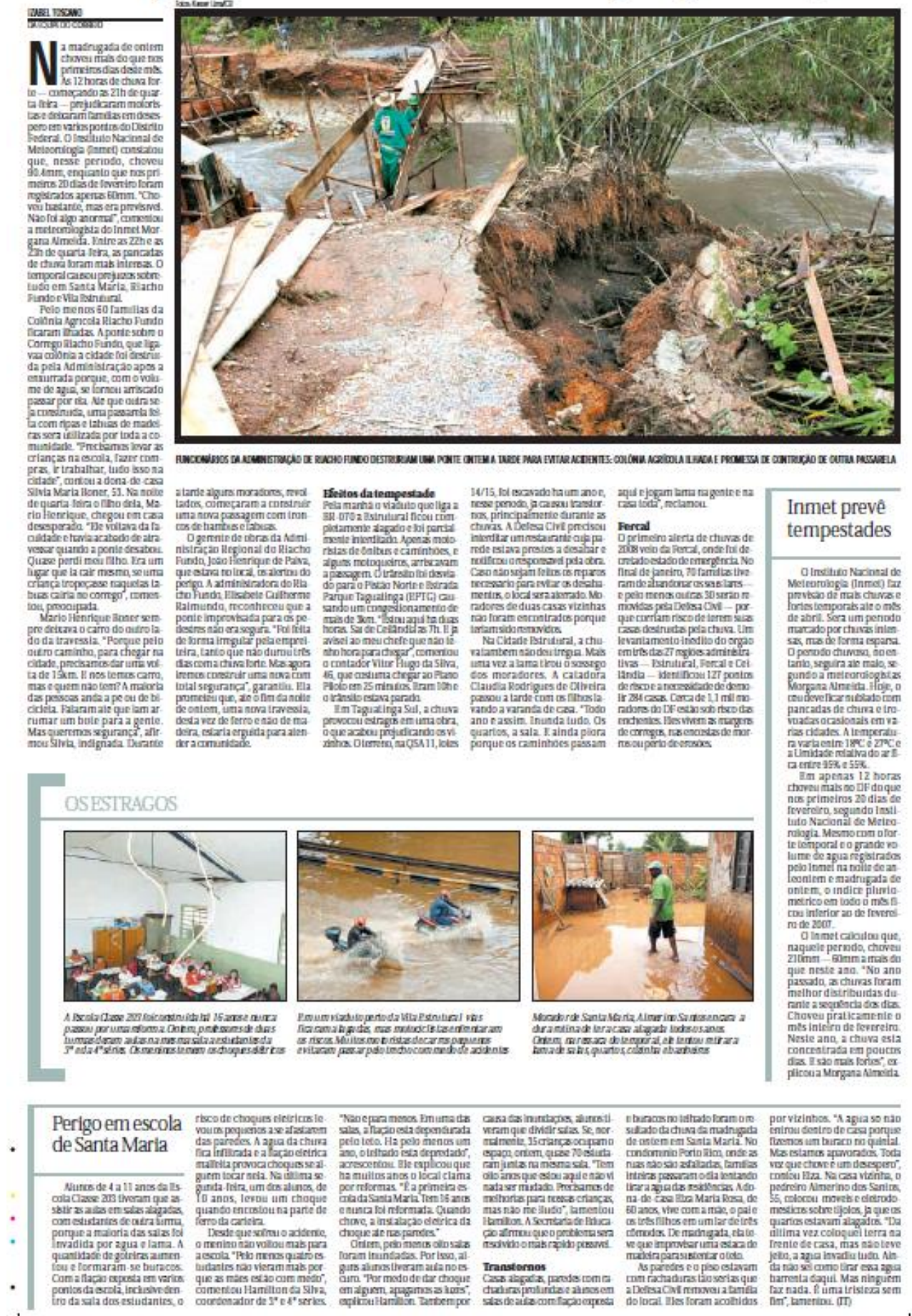

Figura 26. Recorte de reportagem de fevereiro de 2008 (Apêndice XI, Notícia nํ6). Fonte: Correio Braziliense. 


\section{CLIMA}

Temporal que teve início por volta das $16 \mathrm{~h}$ causou alagamentos e 20 acidentes automobilísticos.

Ontem choveu mais na capital do que no estado de Santa Catarina, que vem sofrendo com as tormentas

\section{Sexta-feira encharcada nas vias}
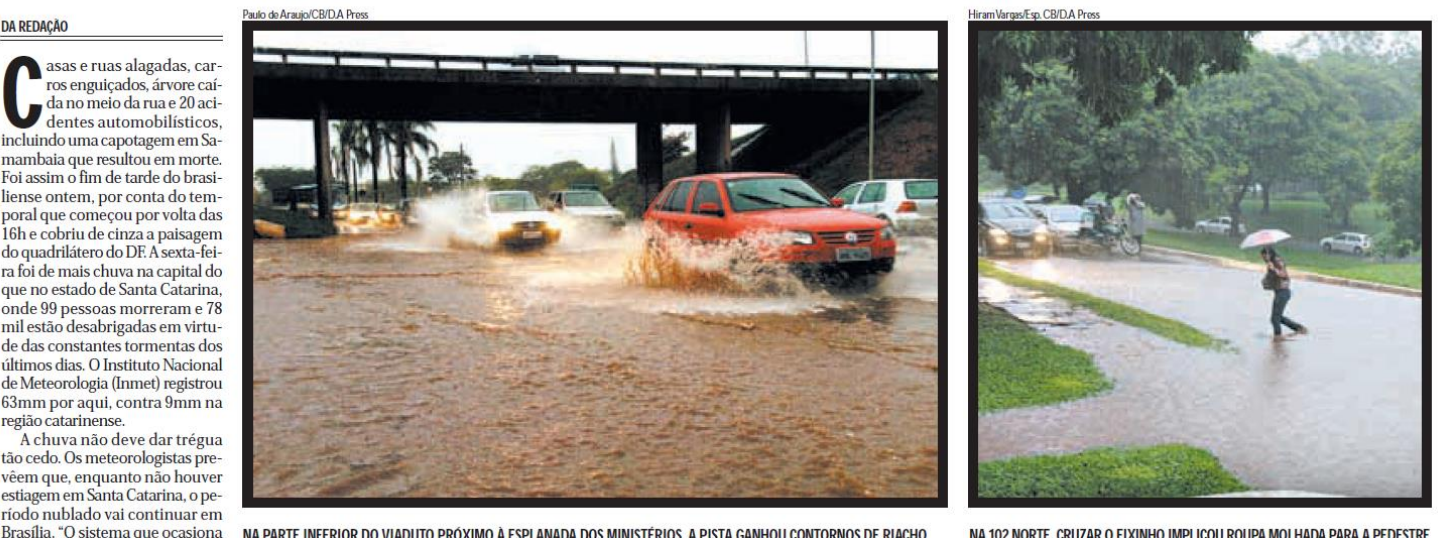

Figura 27. Recorte de reportagem de outubro de 2008 (Apêndice XI, Notícia oㅡ 25). Fonte: Correio Braziliense.

\subsubsection{Ano de 2009}

$\mathrm{O}$ ano de 2009 apresentou um comportamento distinto dos demais. $\mathrm{Na}$ Estação Brasília do INMET registrou um total de precipitação acumulada anualmente de 1792,9 mm de chuva (Gráfico 44), aproximadamente 16\% acima da média de precipitação anual da Normal Climatológica. Todavia a Estação Roncador do INMET registrou 1396,6 mm, cerca de 10\% abaixo da média histórica, que é de 1540,6 mm (Gráfico 45).

Na Estação Brasília, o ano de 2009 foi o mais chuvoso dentre todos os anos estudados, com as precipitações acumuladas mensalmente foram irregulares. O mês de abril apresentou uma configuração atípica, tendo registrado $375,9 \mathrm{~mm}$, o triplo do que normalmente é esperado para o período (123,8 mm, de acordo com a Normal). A média de precipitação acumulada mensalmente foi superada em abril, maio, junho, agosto, outubro e dezembro.

$\mathrm{Na}$ Estação Roncador, as chuvas foram irregulares. Verificou-se que assim como na Estação Brasília, o período de estiagem também foi curto. A 
média de precipitação acumulada mensalmente foi superada em abril, maio, agosto, outubro e dezembro.

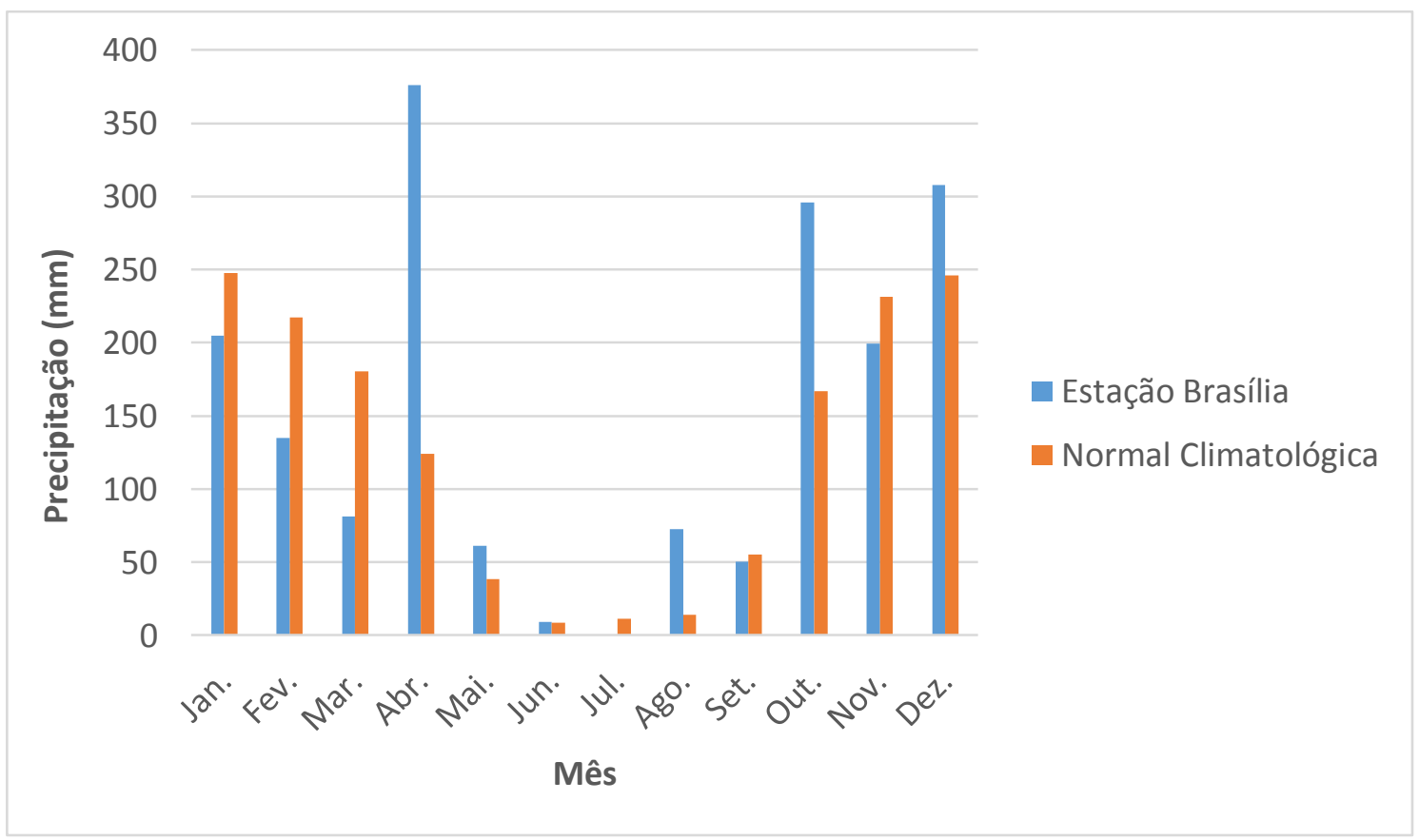

Gráfico 44. Precipitação mensal acumulada em 2009 na Estação Brasília do INMET (DF).

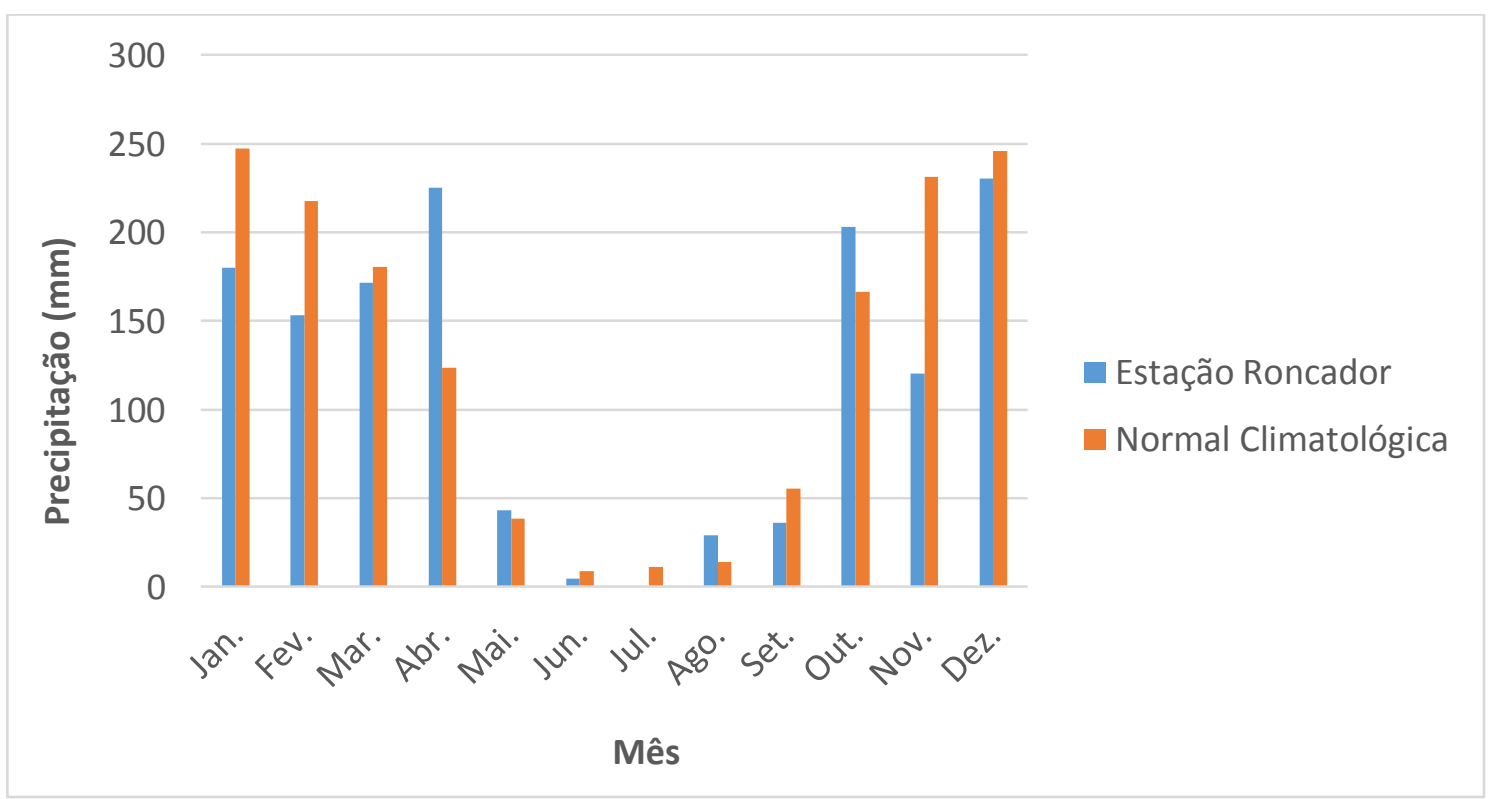

Gráfico 45. Precipitação mensal acumulada em 2009 na Estação Roncador do INMET (DF).

Em 2009 foram encontradas apenas 10 reportagens referentes à desastres naturais associados às precipitações, em fevereiro, março, abril, 
setembro, outubro e dezembro, como pode ser aferido no Gráfico 46 e no Apêndice $X$.

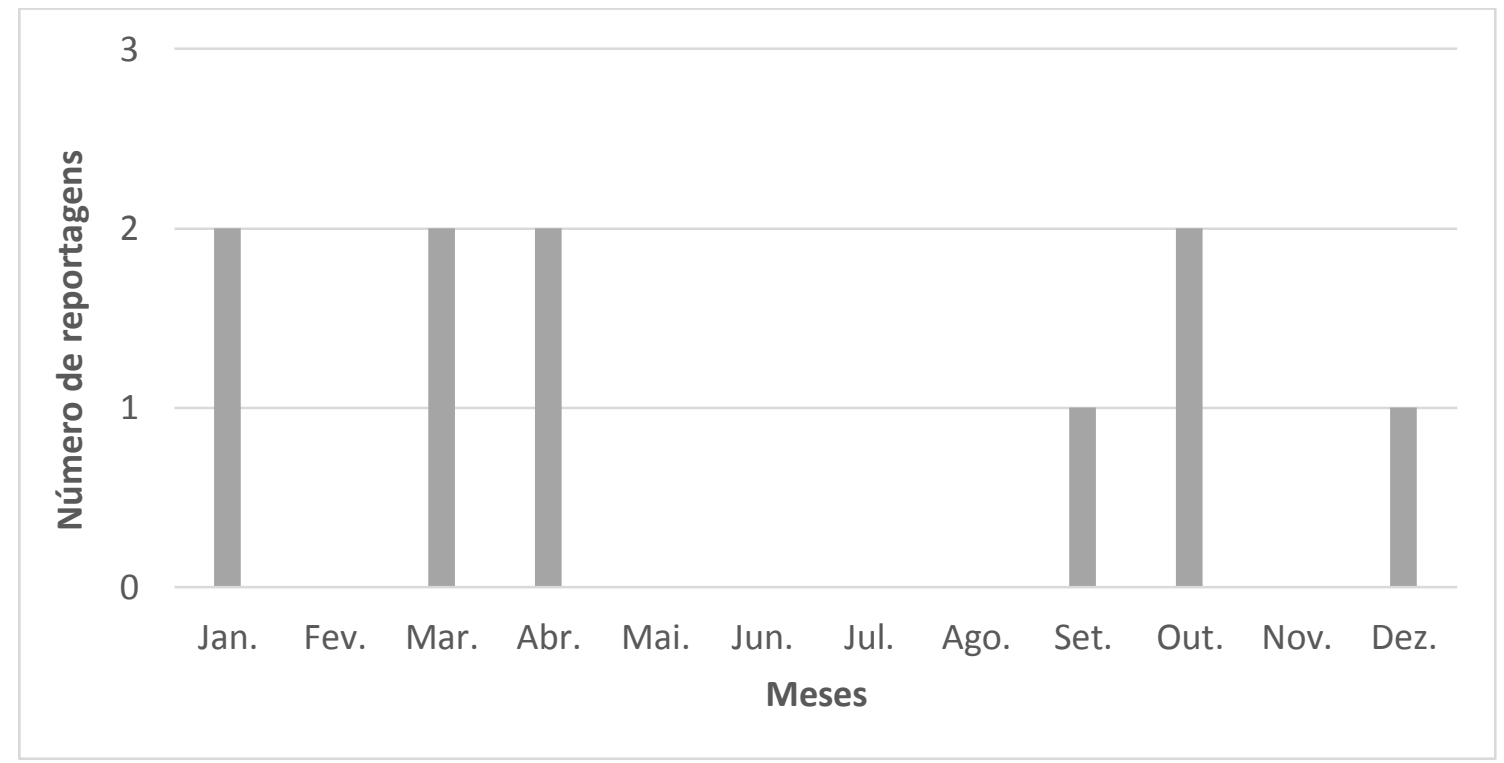

Gráfico 46. Número de reportagens encontradas mensalmente em 2009. Fonte dos dados: Correio Braziliense. Elaborado pelo autor.

De acordo com o que foi registrado nas reportagens, as Regiões Administrativas mais afetadas foram o Plano Piloto (RA I), com 10 ocorrências de desastres; Ceilândia (RA IX) e Águas Claras (RA XX) com 4 ocorrências.

\begin{tabular}{|c|c|c|c|c|c|c|c|}
\hline $\begin{array}{l}\text { Região } \\
\text { Administrativa }\end{array}$ & Alagamento & Enxurrada & Erosão & Granizo & $\begin{array}{c}\text { Movimento } \\
\text { de Massa }\end{array}$ & Vendaval & Total \\
\hline $\begin{array}{l}\text { Plano Piloto } \\
\text { (RA I) }\end{array}$ & 4 & 2 & 1 & 0 & 0 & 3 & 10 \\
\hline Gama (RA II) & 0 & 0 & 0 & 0 & 0 & 1 & 1 \\
\hline $\begin{array}{l}\text { Taguatinga (RA } \\
\text { III) }\end{array}$ & 1 & 0 & 0 & 2 & 0 & 0 & 3 \\
\hline $\begin{array}{l}\text { Brazlândia (RA } \\
\text { IV) }\end{array}$ & 0 & 0 & 0 & 0 & 0 & 0 & 0 \\
\hline $\begin{array}{l}\text { Sobradinho (RA } \\
\text { V) }\end{array}$ & 0 & 0 & 1 & 0 & 1 & 1 & 3 \\
\hline $\begin{array}{l}\text { Planaltina (RA } \\
\text { VI) }\end{array}$ & 0 & 0 & 0 & 0 & 0 & 0 & 0 \\
\hline $\begin{array}{l}\text { Paranoá (RA } \\
\text { VII) }\end{array}$ & 0 & 0 & 0 & 0 & 0 & 0 & 0 \\
\hline $\begin{array}{l}\text { Núcleo } \\
\text { Bandeirante } \\
\text { (RA VIII) }\end{array}$ & 0 & 0 & 0 & 0 & 0 & 0 & 0 \\
\hline $\begin{array}{l}\text { Ceilândia (RA } \\
\text { IX) }\end{array}$ & 2 & 0 & 1 & 0 & 0 & 1 & 4 \\
\hline Guará (RA X) & 0 & 0 & 0 & 0 & 0 & 0 & 0 \\
\hline Cruzeiro (RA XI) & 0 & 0 & 0 & 0 & 0 & 0 & 0 \\
\hline
\end{tabular}




\begin{tabular}{|c|c|c|c|c|c|c|c|}
\hline $\begin{array}{l}\text { Samambaia (RA } \\
\text { XII) }\end{array}$ & 0 & 0 & 0 & 2 & 0 & 0 & 2 \\
\hline $\begin{array}{l}\text { Santa Maria } \\
\text { (RA XIII) }\end{array}$ & 0 & 0 & 0 & 0 & 0 & 0 & 0 \\
\hline $\begin{array}{l}\text { São Sebastião } \\
\text { (RA XIV) }\end{array}$ & 0 & 0 & 0 & 0 & 0 & 0 & 0 \\
\hline $\begin{array}{l}\text { Recanto das } \\
\text { Emas (RA XV) }\end{array}$ & 0 & 0 & 0 & 0 & 0 & 0 & 0 \\
\hline $\begin{array}{l}\text { Lago Sul (RA } \\
\text { XVI) }\end{array}$ & 0 & 0 & 0 & 0 & 0 & 0 & 0 \\
\hline $\begin{array}{l}\text { Riacho Fundo } \\
\text { (RA XVII) }\end{array}$ & 0 & 0 & 0 & 0 & 0 & 0 & 0 \\
\hline $\begin{array}{l}\text { Lago Norte (RA } \\
\text { XVIII) }\end{array}$ & 0 & 0 & 0 & 0 & 0 & 0 & 0 \\
\hline $\begin{array}{l}\text { Candangolândia } \\
\text { (RA XIX) }\end{array}$ & 0 & 0 & 0 & 0 & 0 & 0 & 0 \\
\hline $\begin{array}{l}\text { Águas Claras } \\
\text { (RA XX) }\end{array}$ & 2 & 1 & 0 & 1 & 0 & 0 & 4 \\
\hline $\begin{array}{l}\text { Riacho Fundo II } \\
\text { (RA XXI) }\end{array}$ & 0 & 0 & 0 & 0 & 0 & 0 & 0 \\
\hline $\begin{array}{l}\text { Sudoeste / } \\
\text { Octogonal (RA } \\
\text { XXII) }\end{array}$ & 0 & 0 & 0 & 0 & 0 & 0 & 0 \\
\hline $\begin{array}{l}\text { Varjão (RA } \\
\text { XXIII) }\end{array}$ & 0 & 0 & 0 & 0 & 0 & 0 & 0 \\
\hline $\begin{array}{l}\text { Park Way (RA } \\
\text { XXIV) }\end{array}$ & 0 & 0 & 1 & 0 & 1 & 0 & 2 \\
\hline $\begin{array}{l}\text { Setor } \\
\text { Complementar } \\
\text { de Indústria e } \\
\text { Abastecimento } \\
\text { (RA XXV) }\end{array}$ & 0 & 0 & 0 & 0 & 0 & 0 & 0 \\
\hline $\begin{array}{l}\text { Sobradinho II } \\
\text { (RA XXVI) }\end{array}$ & 0 & 0 & 0 & 0 & 0 & 0 & 0 \\
\hline $\begin{array}{l}\text { Jardim Botânico } \\
\text { (RA XXVII) }\end{array}$ & 0 & 0 & 0 & 0 & 0 & 0 & 0 \\
\hline $\begin{array}{l}\text { Itapoã (RA } \\
\text { XXVII) }\end{array}$ & 1 & 0 & 0 & 0 & 0 & 0 & 1 \\
\hline $\begin{array}{l}\text { Setor de } \\
\text { Indústria e } \\
\text { Abastecimento } \\
\text { (RA XXIX) }\end{array}$ & 0 & 0 & 0 & 0 & 0 & 0 & 0 \\
\hline $\begin{array}{l}\text { Vicente Pires } \\
\text { (RA XXX) }\end{array}$ & 2 & 0 & 0 & 0 & 0 & 0 & 2 \\
\hline Fercal (RA XXXI) & 0 & 0 & 0 & 0 & 0 & 0 & 0 \\
\hline Total & 12 & 3 & 4 & 5 & 2 & 6 & 32 \\
\hline
\end{tabular}

Quadro 11. Número de reportagens encontradas mensalmente em 2009 com tipologia de desastres naturais. Elaborado pelo autor.

Em relação à tipologia de desastres naturais, os alagamentos foram os desastres naturais que ocorreram com maior frequência, sendo observados 12 vezes nas Regiões Administrativas; seguido por vendavais, com 6 ocorrências; queda de granizo, com 5 ocorrências; erosões, com 5 ocorrências; enxurradas, 
com 3 ocorrências; e movimentos de massa, com 2 ocorrências. As porcentagens de cada tipo de desastres podem ser observadas no Gráfico 47.

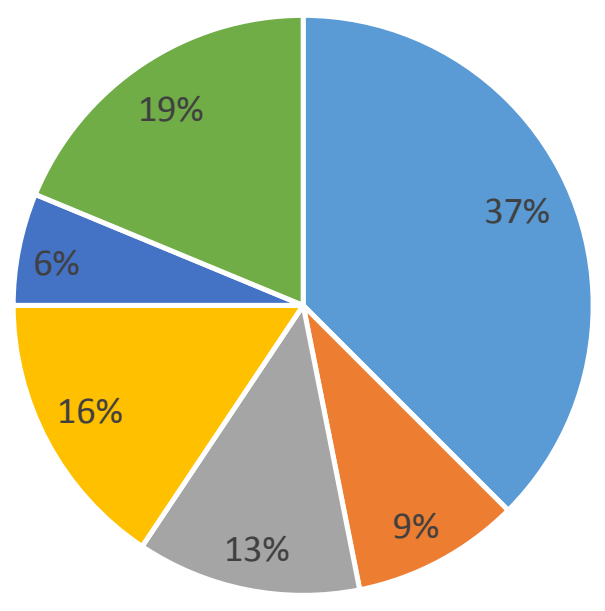

- Alagamento

- Enxurrada

- Erosão

- Granizo

- Movimento de Massa

- Vendaval

Gráfico 47. Porcentagem de desastres naturais encontrados nas reportagens ocorridos em 2008. Elaborado pelo autor.

No ano de 2009, duas reportagens se destacam. A primeira, em janeiro, relata os desastres causados pela tempestade que caiu na tarde do dia 8 , por volta das $14 \mathrm{~h} 30$ no Plano Piloto. A precipitação provocou alagamentos, estouros de encanamento, congestionamentos, paralisação do metrô, quedas de árvore e falta de energia elétrica em parte do Distrito Federal.

Na segunda reportagem, em abril, o Corpo de Bombeiros precisou de máquinas de sucção para tirar água de garagens alagadas na W3 Norte. Em Águas Claras, um muro caiu com a enxurrada. A água chegou a $60 \mathrm{~cm}$ de altura. A reportagem informou, baseada em informações do INMET que em seis horas, entre as $2 \mathrm{~h}$ e as $8 \mathrm{~h}$, choveu $98,1 \mathrm{~mm}$. Em 13 dias, o acumulado é de $232,8 \mathrm{~mm}-100 \mathrm{~mm}$ a mais que a média prevista para o mês, de $123,8 \mathrm{~mm}$. Sinal de que este pode ser o abril mais chuvoso da história. Até hoje, o recorde pertence ao ano de 1992. O Corpo de Bombeiros ainda registrou outras 11 chamadas por alagamento. De acordo com o noticiado, as quadras mais afetadas foram a 210,311 e 511 Norte. 
CLIMA

A quantidade de água que calu em apenas duas horas na tarde de ontem na capital provocou estragos, complicou o trânsito e o dia dos brasilienses. Previsåo do Inmet é de mais chuva para hoje
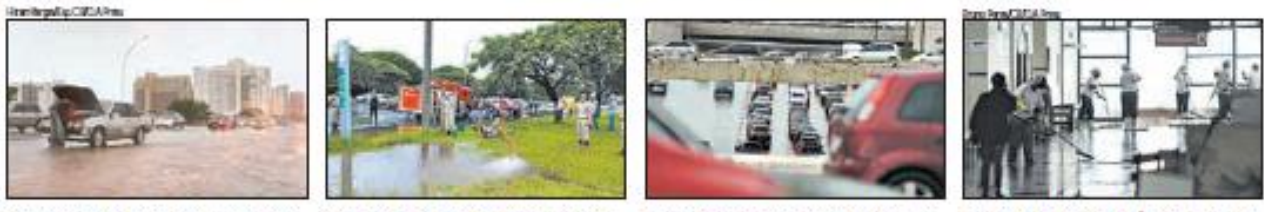

\section{Temporal de parar a cidade}

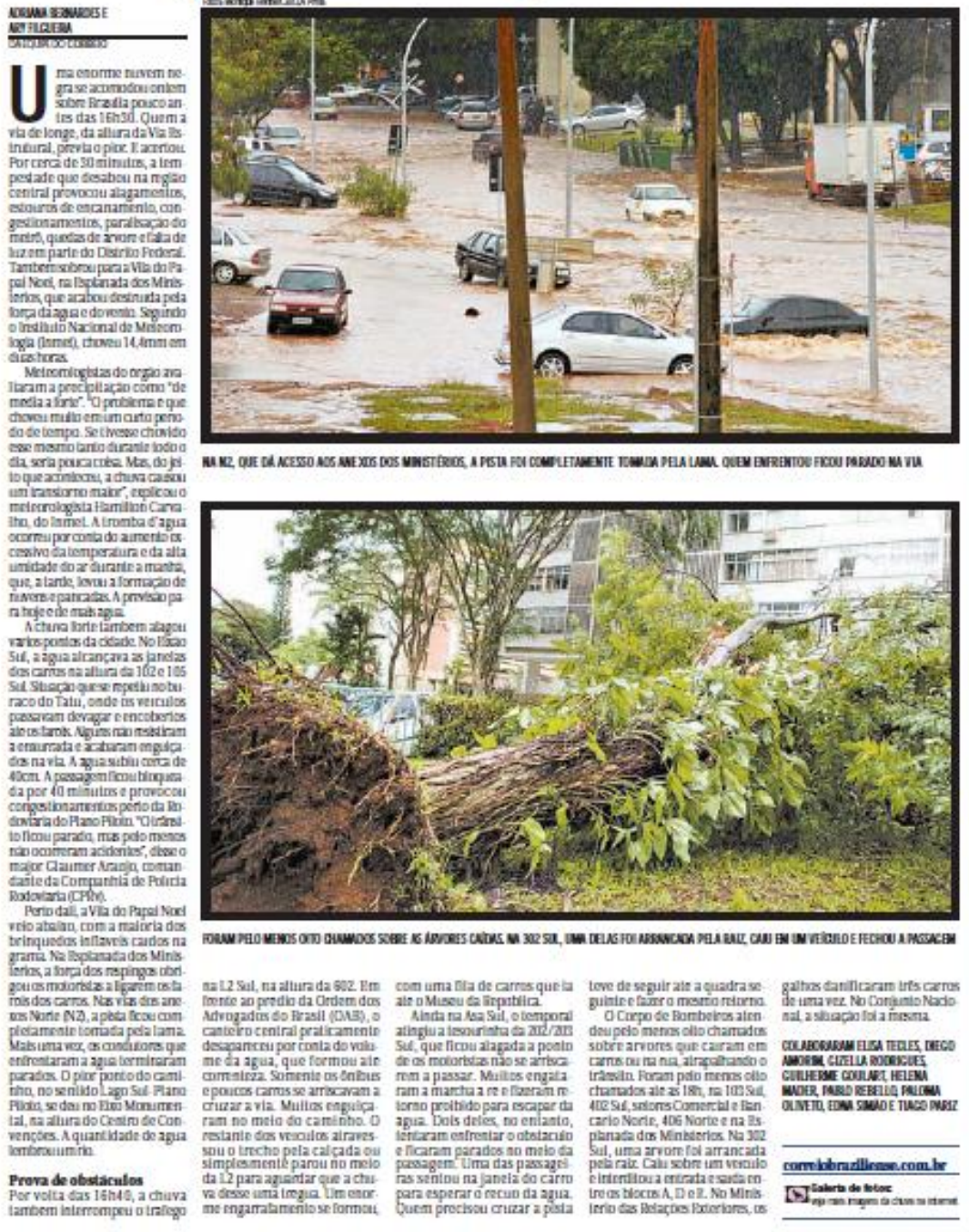

Semluzaté no Planalto

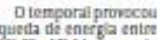

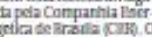

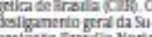

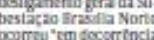

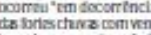

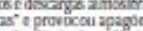

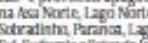

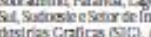

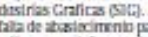
redisne a moino nas rst

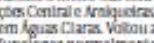
funcibarar normalit Na lspianada tos $\mathrm{M}$ nibierias ande himu dilt

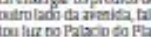

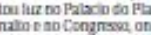

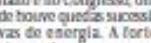
huva chrgous a caus:

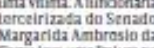

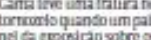
100 ansos da morte do os galuem enmascedadevists anvendaral. Dsocori

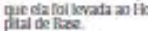

Intentizado Onterdizado

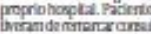

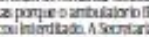

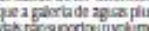
dezyuetranstortoul do

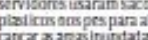

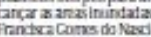

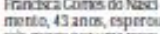

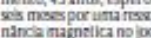
namra magnetica no joc

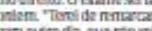
pracareods quaren x

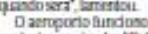

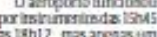

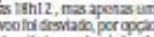

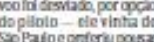

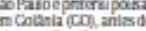
nyendils Dostations
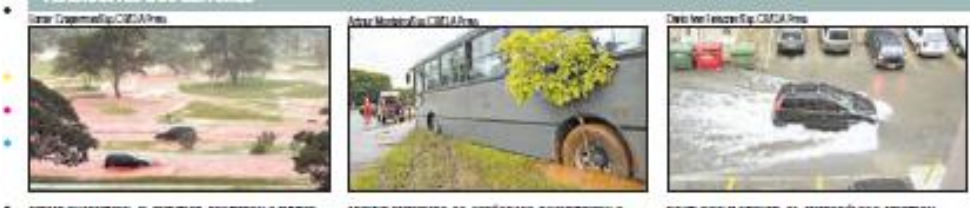

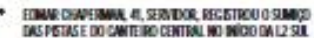

(1)

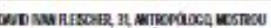

Magrom

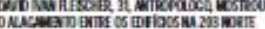

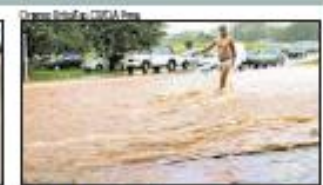

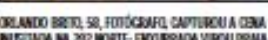

Figura 28. Recorte de reportagem de janeiro de 2009 (Apêndice X, Notícia no 1). Fonte: Correio Braziliense. 


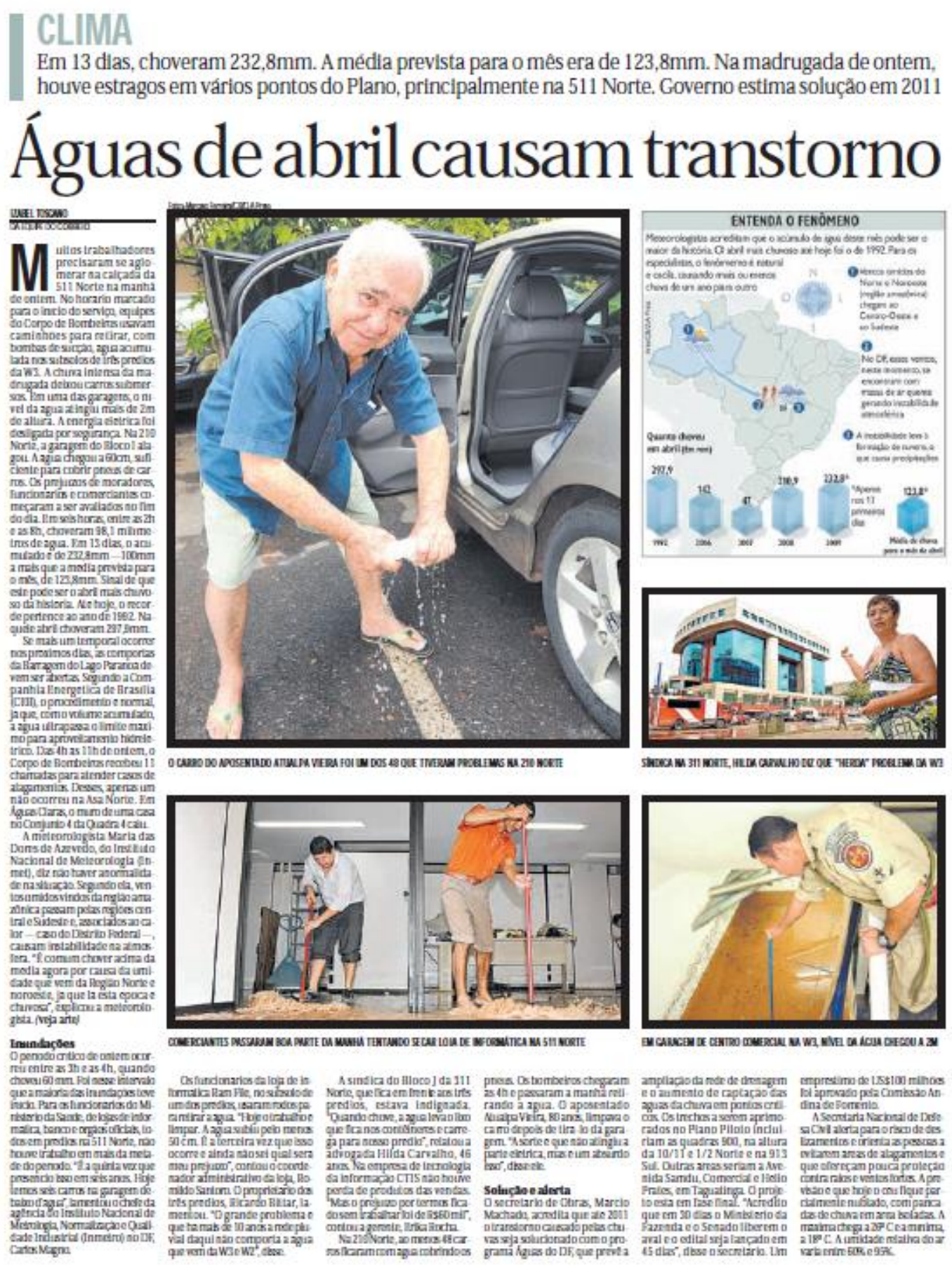

Figura 29. Recorte de reportagem de abril de 2009 (Apêndice X, Notícia ํㅡ6). Fonte: Correio Braziliense.

\subsubsection{Ano de 2010}

O ano de 2010 foi um ano pouco chuvoso. Na Estação Brasília do INMET registrou um total de precipitação acumulada anualmente de 1431,6 $\mathrm{mm}$ de chuva (Gráfico 48), aproximadamente 7\% abaixo da média de precipitação anual da Normal Climatológica, enquanto que a Estação Roncador 
do INMET registrou 1476,9 mm, cerca de $5 \%$ abaixo da média histórica, que é de 1540,6 mm (Gráfico 49).

No início do ano as estações meteorológicas apresentaram comportamentos distintos. Na Estação Brasília, as chuvas foram abaixo da média em janeiro e fevereiro, superando-a em março e abril. Na Estação Roncador, as chuvas superaram o esperado em janeiro e março. A longa estiagem se encerrou em outubro, com a retomada das precipitações, que ocorreram acima da média e seguiram essa tendência em novembro e dezembro nas duas estações.

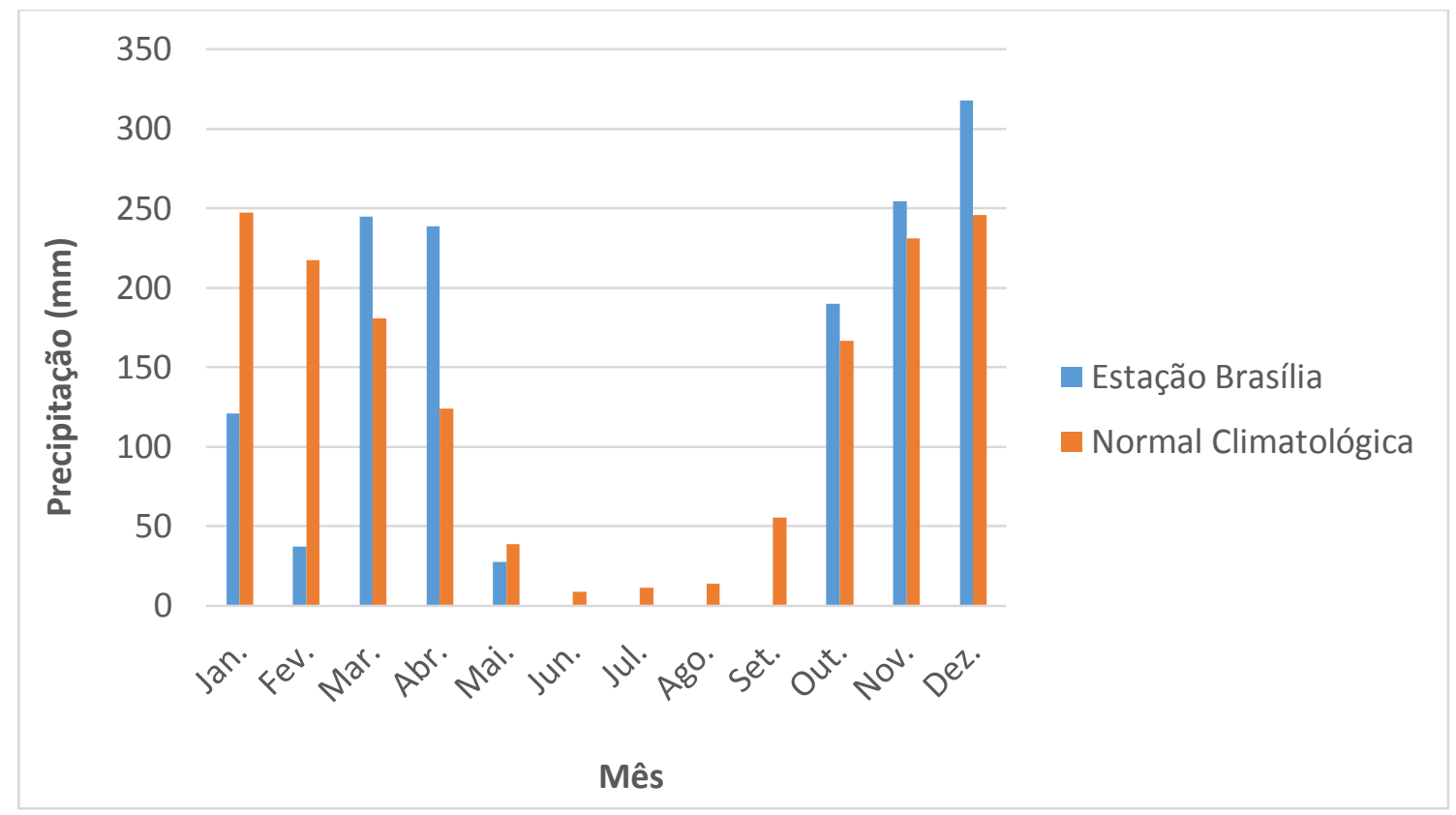

Gráfico 48. Precipitação mensal acumulada em 2010 na Estação Brasília do INMET (DF). 


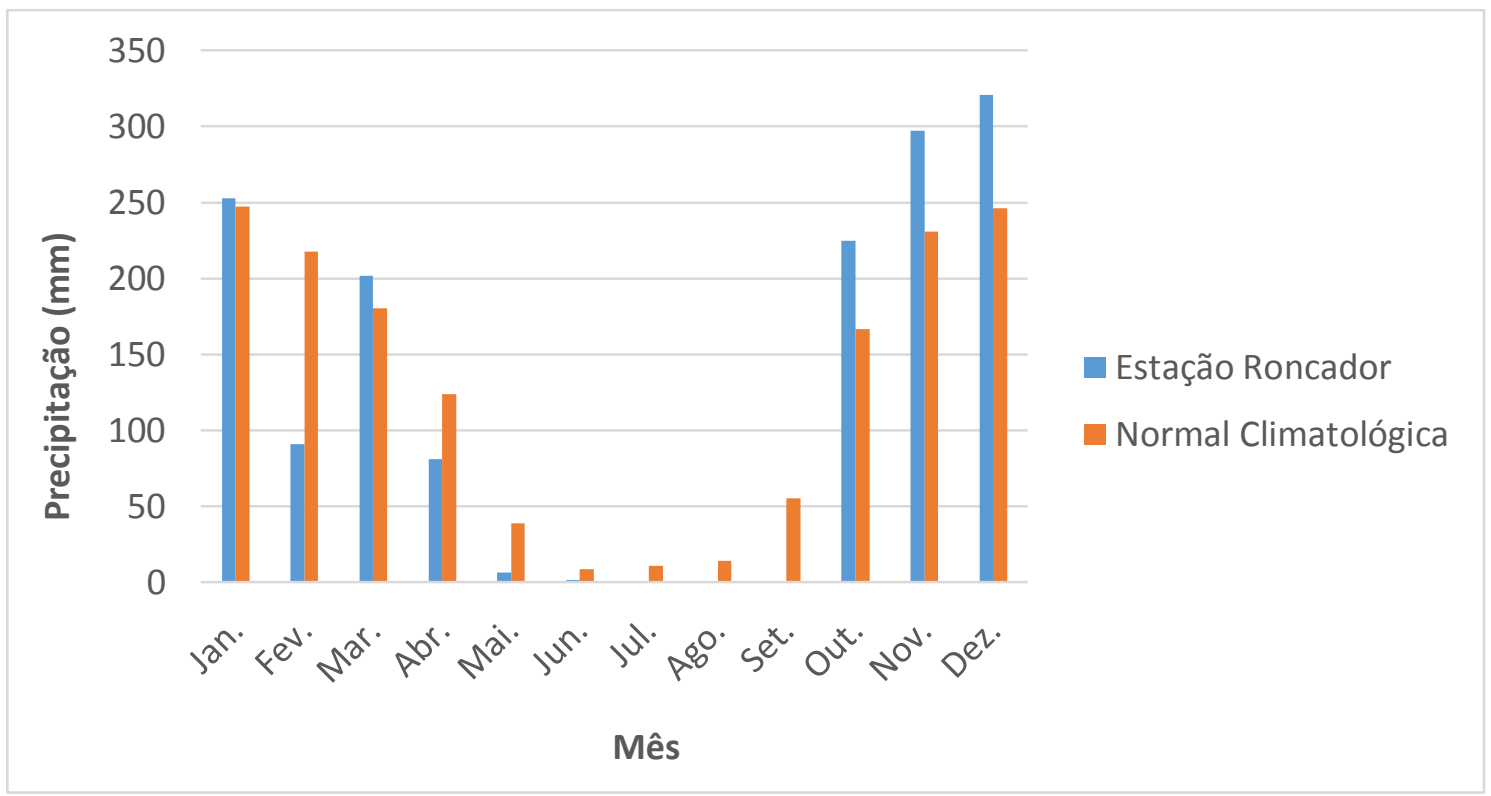

Gráfico 49. Precipitação mensal acumulada em 2010 na Estação Roncador do INMET (DF).

Em 2010 foram encontradas apenas 14 reportagens referentes à desastres naturais associados às precipitações, em fevereiro, março, abril, setembro, outubro e novembro, como pode ser aferido no Gráfico 50 e no Apêndice XI.

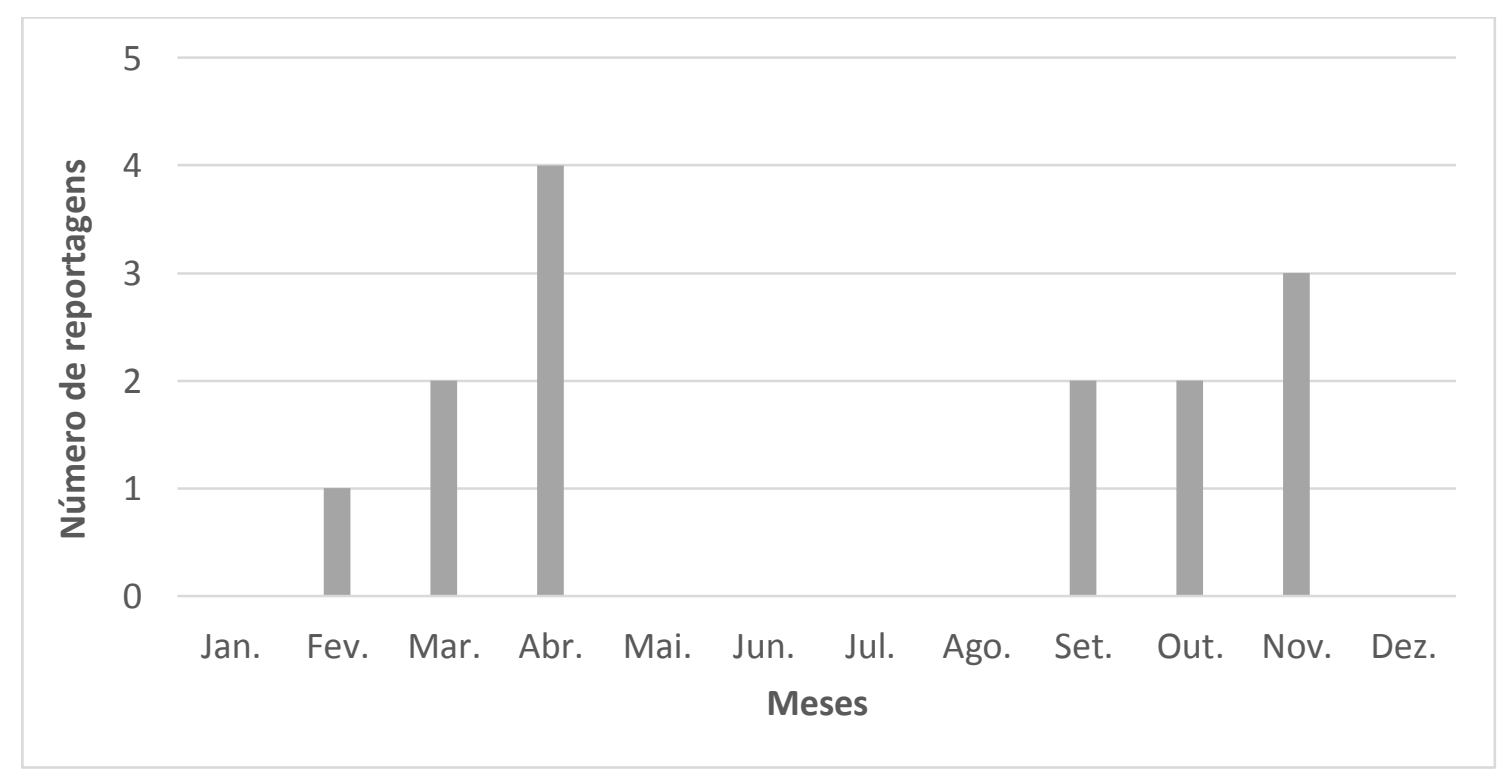

Gráfico 50. Número de reportagens encontradas mensalmente em 2009. Fonte dos dados: Correio Braziliense. Elaborado pelo autor.

De acordo com o que foi registrado nas reportagens, as Regiões Administrativas mais afetadas foram o Plano Piloto (RA I), com 11 ocorrências 
de desastres; seguido por Taguatinga (RA III), Ceilândia (RA IX) e Vicente Pires (RA XXX) com 5 ocorrências cada.

\begin{tabular}{|c|c|c|c|c|c|c|c|}
\hline $\begin{array}{l}\text { Região } \\
\text { Administrativa }\end{array}$ & Alagamento & Enxurrada & Erosão & Granizo & $\begin{array}{c}\text { Movimento } \\
\text { de Massa }\end{array}$ & Vendaval & Total \\
\hline $\begin{array}{l}\text { Plano Piloto } \\
\text { (RA I) }\end{array}$ & 9 & 2 & 0 & 0 & 0 & 0 & 11 \\
\hline Gama (RA II) & 2 & 0 & 0 & 0 & 0 & 0 & 2 \\
\hline $\begin{array}{l}\text { Taguatinga (RA } \\
\text { III) }\end{array}$ & 3 & 2 & 0 & 0 & 0 & 0 & 5 \\
\hline $\begin{array}{l}\text { Brazlândia (RA } \\
\text { IV) }\end{array}$ & 0 & 0 & 0 & 0 & 0 & 0 & 0 \\
\hline $\begin{array}{l}\text { Sobradinho (RA } \\
\text { V) }\end{array}$ & 0 & 0 & 0 & 0 & 0 & 0 & 0 \\
\hline $\begin{array}{l}\text { Planaltina (RA } \\
\text { VI) }\end{array}$ & 0 & 0 & 0 & 0 & 0 & 0 & 0 \\
\hline $\begin{array}{l}\text { Paranoá (RA } \\
\text { VII) }\end{array}$ & 0 & 0 & 0 & 0 & 0 & 0 & 0 \\
\hline $\begin{array}{l}\text { Núcleo } \\
\text { Bandeirante } \\
\text { (RA VIII) }\end{array}$ & 0 & 0 & 0 & 0 & 0 & 0 & 0 \\
\hline $\begin{array}{l}\text { Ceilândia (RA } \\
\text { IX) }\end{array}$ & 2 & 1 & 0 & 0 & 1 & 1 & 5 \\
\hline Guará (RA X) & 0 & 0 & 0 & 0 & 0 & 0 & 0 \\
\hline Cruzeiro (RA XI) & 1 & 0 & 0 & 0 & 0 & 0 & 1 \\
\hline $\begin{array}{l}\text { Samambaia (RA } \\
\text { XII) }\end{array}$ & 0 & 0 & 0 & 0 & 0 & 0 & 0 \\
\hline $\begin{array}{l}\text { Santa Maria } \\
\text { (RA XIII) }\end{array}$ & 0 & 0 & 0 & 0 & 0 & 0 & 0 \\
\hline $\begin{array}{l}\text { São Sebastião } \\
\text { (RA XIV) }\end{array}$ & 1 & 1 & 0 & 0 & 0 & 1 & 3 \\
\hline $\begin{array}{l}\text { Recanto das } \\
\text { Emas (RA XV) }\end{array}$ & 0 & 0 & 0 & 0 & 0 & 0 & 0 \\
\hline $\begin{array}{l}\text { Lago Sul (RA } \\
\text { XVI) }\end{array}$ & 0 & 0 & 0 & 0 & 0 & 0 & 0 \\
\hline $\begin{array}{l}\text { Riacho Fundo } \\
\text { (RA XVII) }\end{array}$ & 0 & 0 & 0 & 0 & 0 & 0 & 0 \\
\hline $\begin{array}{l}\text { Lago Norte (RA } \\
\text { XVIII) }\end{array}$ & 0 & 0 & 0 & 0 & 0 & 0 & 0 \\
\hline $\begin{array}{l}\text { Candangolândia } \\
\text { (RA XIX) }\end{array}$ & 0 & 0 & 0 & 0 & 0 & 0 & 0 \\
\hline $\begin{array}{l}\text { Águas Claras } \\
\text { (RA XX) }\end{array}$ & 0 & 0 & 0 & 0 & 0 & 0 & 0 \\
\hline $\begin{array}{l}\text { Riacho Fundo II } \\
\text { (RA XXI) }\end{array}$ & 0 & 0 & 0 & 0 & 0 & 0 & 0 \\
\hline $\begin{array}{l}\text { Sudoeste / } \\
\text { Octogonal (RA } \\
\text { XXII) }\end{array}$ & 0 & 0 & 0 & 0 & 0 & 0 & 0 \\
\hline $\begin{array}{l}\text { Varjão (RA } \\
\text { XXIII) }\end{array}$ & 0 & 0 & 0 & 0 & 0 & 0 & 0 \\
\hline $\begin{array}{l}\text { Park Way (RA } \\
\text { XXIV) }\end{array}$ & 0 & 0 & 0 & 0 & 0 & 0 & 0 \\
\hline $\begin{array}{l}\text { Setor } \\
\text { Complementar }\end{array}$ & 1 & 0 & 0 & 0 & 0 & 0 & 1 \\
\hline
\end{tabular}




\begin{tabular}{|c|c|c|c|c|c|c|c|}
\hline $\begin{array}{l}\text { de Indústria e } \\
\text { Abastecimento } \\
\text { (RA XXV) }\end{array}$ & & & & & & & \\
\hline $\begin{array}{l}\text { Sobradinho II } \\
\text { (RA XXVI) }\end{array}$ & 1 & 0 & 2 & 0 & 0 & 0 & 3 \\
\hline $\begin{array}{l}\text { Jardim Botânico } \\
\text { (RA XXVII) }\end{array}$ & 0 & 0 & 0 & 0 & 0 & 0 & 0 \\
\hline $\begin{array}{l}\text { Itapoã (RA } \\
\text { XXVII) }\end{array}$ & 0 & 0 & 0 & 0 & 0 & 0 & 0 \\
\hline $\begin{array}{l}\text { Setor de } \\
\text { Indústria e } \\
\text { Abastecimento } \\
\text { (RA XXIX) }\end{array}$ & 0 & 0 & 0 & 0 & 0 & 0 & 0 \\
\hline $\begin{array}{l}\text { Vicente Pires } \\
(\text { RA XXX) }\end{array}$ & 3 & 1 & 1 & 0 & 0 & 0 & 5 \\
\hline Fercal (RA XXXI) & 0 & 0 & 0 & 0 & 0 & 0 & 0 \\
\hline Total & 23 & 7 & 3 & 0 & 1 & 2 & 36 \\
\hline
\end{tabular}

Quadro 12. Número de reportagens encontradas mensalmente em 2010 com tipologia de desastres naturais. Elaborado pelo autor.

Em relação à tipologia de desastres naturais, os alagamentos foram os desastres naturais que ocorreram com maior frequência, sendo observados 23 vezes nas Regiões Administrativas; seguido por enxurradas com 7 ocorrências; erosões, com 3 ocorrências; vendavais, com 2 ocorrências; e movimentos de massa, com uma ocorrência. As porcentagens de cada tipo de desastres podem ser observadas no Gráfico 51.

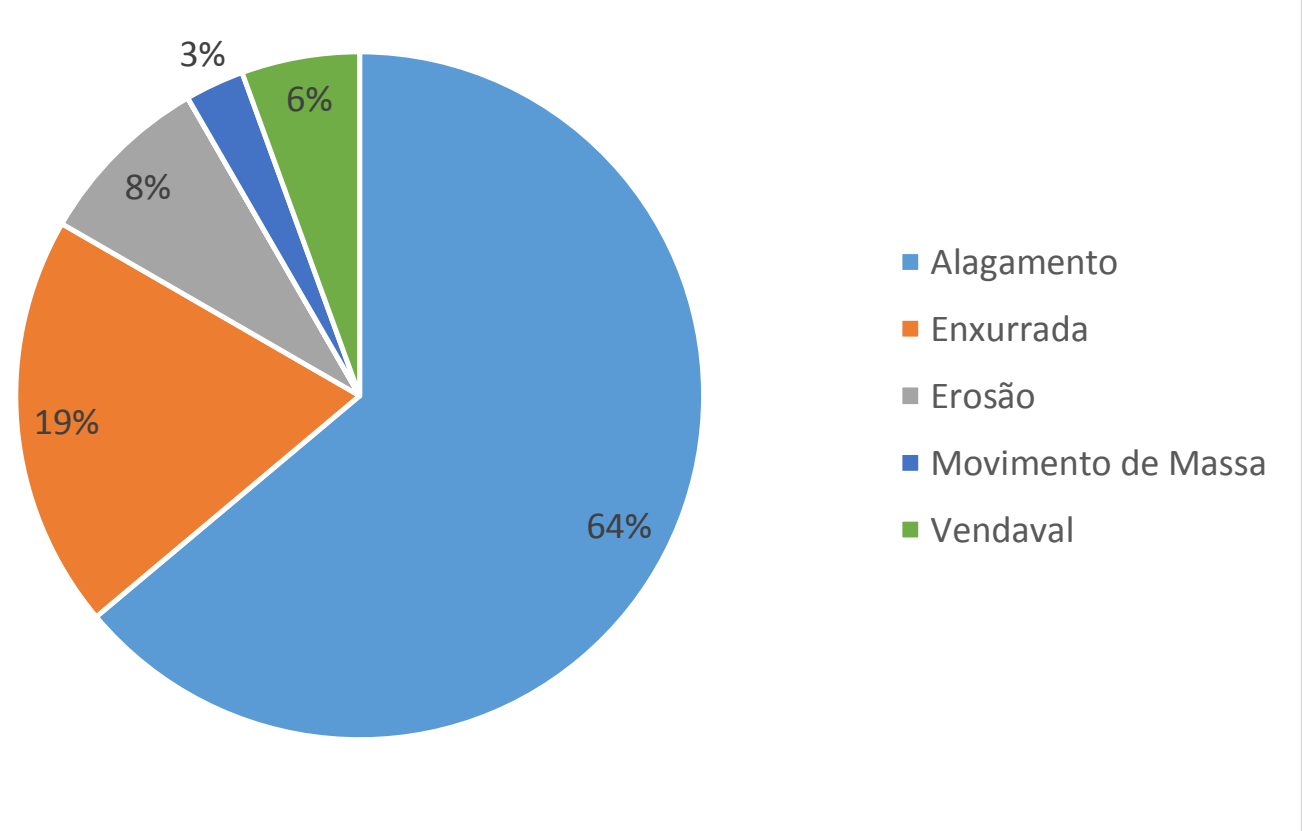

Gráfico 51. Porcentagem de desastres naturais encontrados nas reportagens ocorridos em 2010. Elaborado pelo autor. 
No ano de 2010, três reportagens chamam a atenção. A primeira apresenta um cartograma elaborado pela Defesa Civil com as áreas de risco e vulnerabilidade social e ambiental a desastres naturais associados às chuvas.

A segunda mostra que em apenas 30 minutos de chuva foi alcançado a marca de $47 \mathrm{~mm}$ de água por metro quadrado. Esse evento gerou vários desastres naturais, como os alagamentos das tesourinhas da 302 Norte e 502 Norte.

A terceira expõe como que a falta de planejamento urbano compromete a capacidade de resiliência de uma população. Em uma das primeiras chuvas após o final da seca, enxurrada carregou até manilhas por conta de uma obra realizada em Vicente Pires. A impermeabilização do solo aliada à declividade ainda derrubou muros, queda de energia e bens destruídos foram algumas consequências das primeiras precipitações após fim da estação seca no DF.

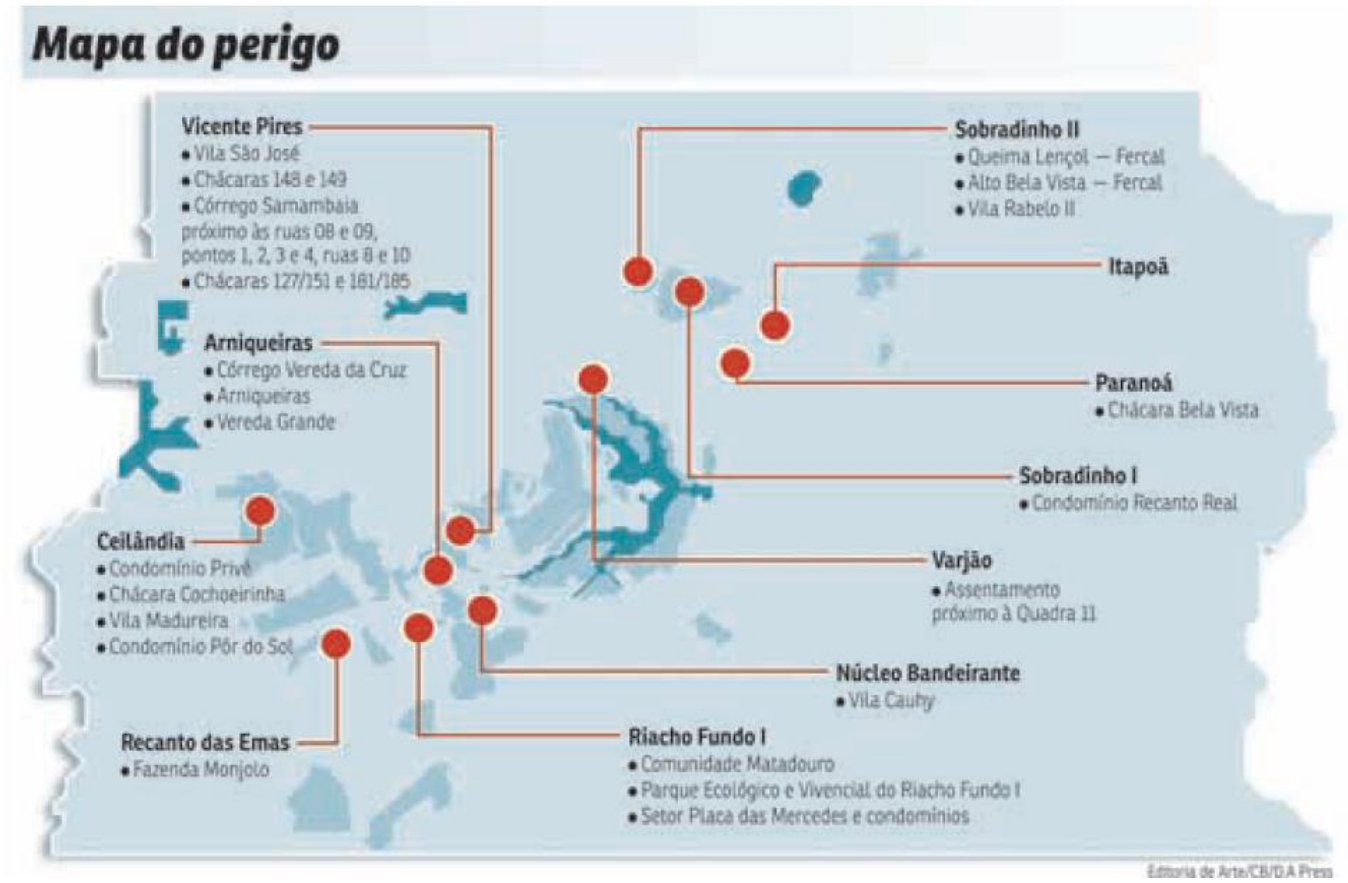

Figura 30. Recorte de reportagem de novembro de 2010 (Apêndice XI, Notícia ํㅜ 13). Fonte: Correio Braziliense. 


\section{TRANSTORNO}
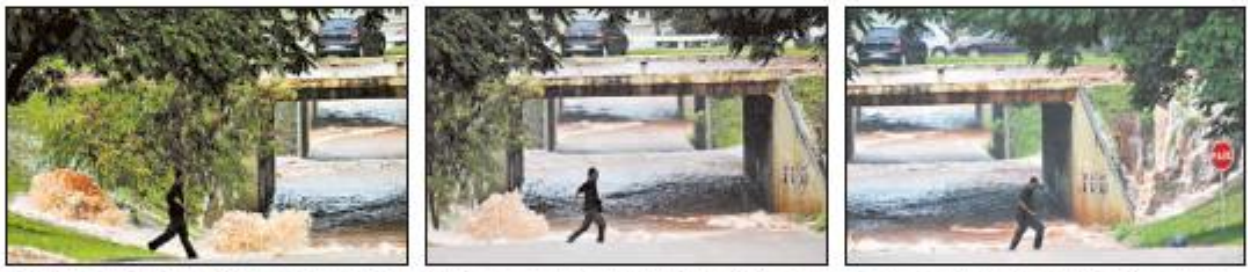

\section{Temporal castiga 0 centro de Brasilia}
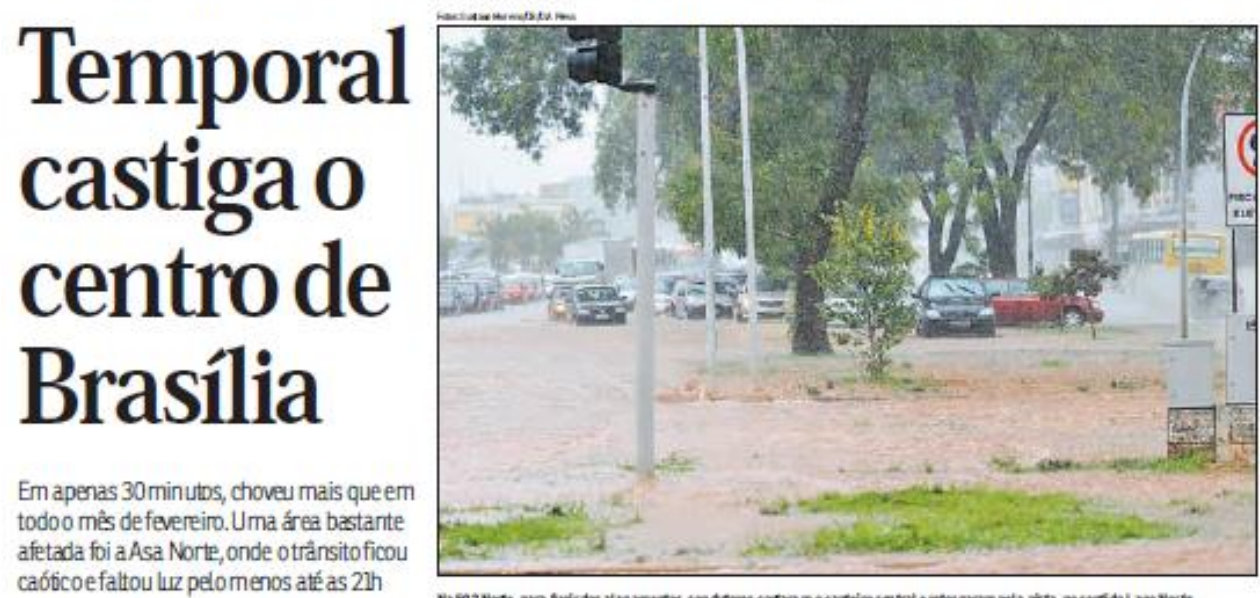

caóticoefaltou ur pelomenos atéas 2
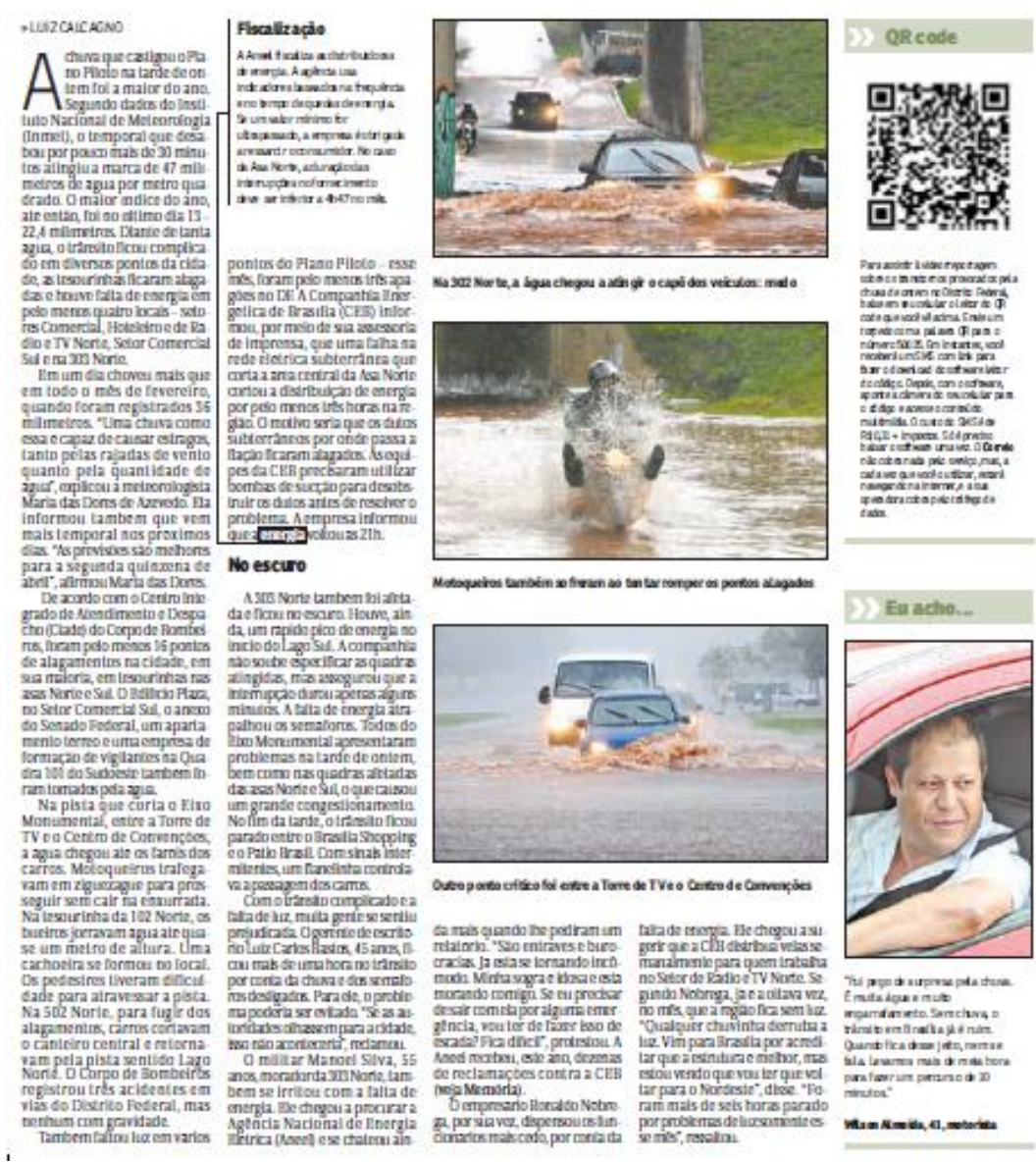

15 Memónla
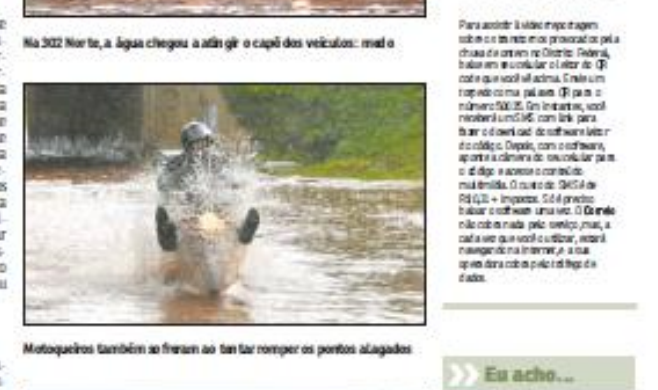

Queixas e multas

Nodimolax omnidn

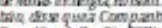

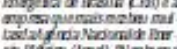

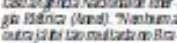

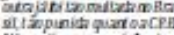

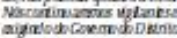

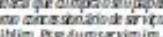
pible Bsclumservipin paes eque posisersestive

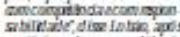

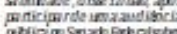

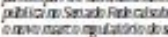
bramincopi

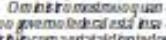

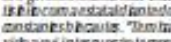

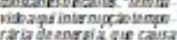
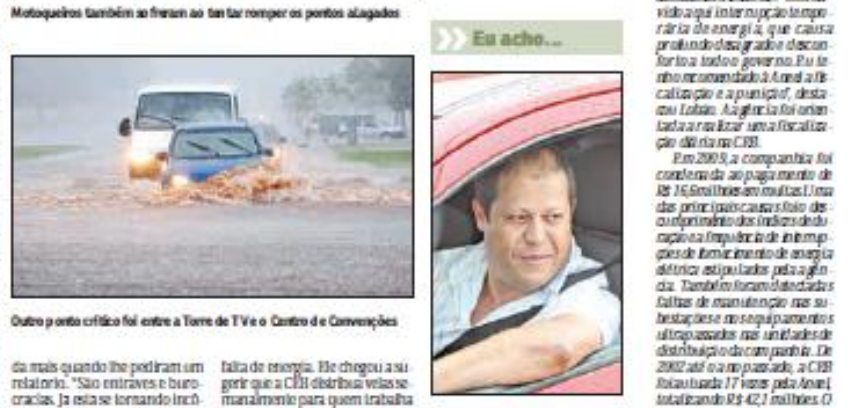

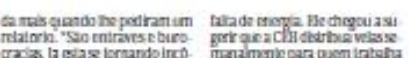
mocromentadederdin

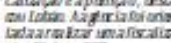

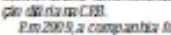

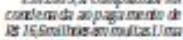

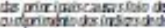

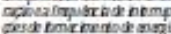

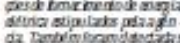

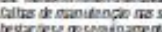

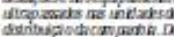

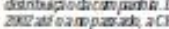

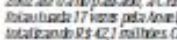

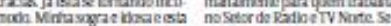

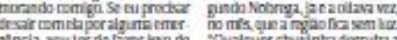

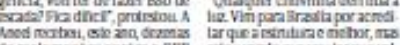

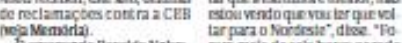

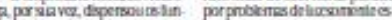

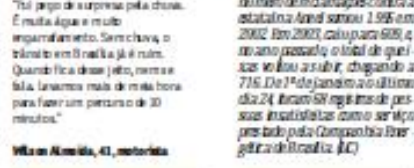

Figura 31. Recorte de reportagem de março de 2010 (Apêndice XI, Notícia no - 2). Fonte: Correio Braziliense. 


\section{Estragos começaram cedo}

Muros derrubad os, queda de energia e bens destruídos foram algumas consequências das primeiras precipitaçōes após a seca. Em Vicente Pires, moradores reclamam de obra na Rua 4 que teria provocado erourrada

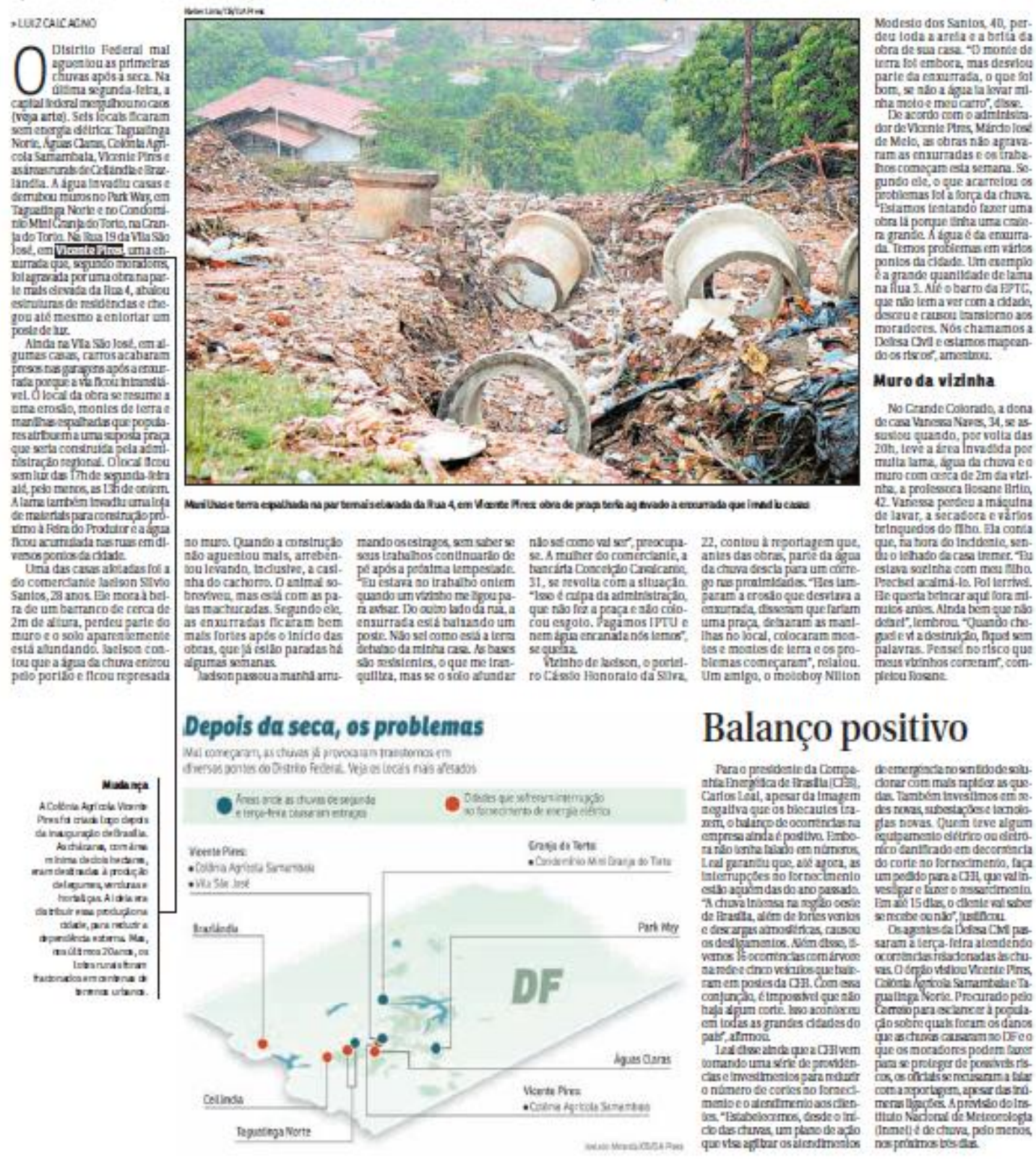

Figura 32. Recorte de reportagem de outubro de 2010 (Apêndice XI, Notícia no 10). Fonte: Correio Braziliense. 


\subsection{Análise do período (2000-2010)}

Os resultados mostraram que entre 2000 e 2010 ocorreram, de acordo com as reportagens, 439 desastres naturais. A Região Administrativa mais afetada por desastres naturais foi o Plano Piloto (RA I) com 100 desastres, seguido por Ceilândia (RA IX) e Taguatinga (RA III), com 31 desastres.

Dentre os 439 desastres, o tipo de desastres que durante a pesquisa foi mais recorrente foram os alagamentos, com 217 relatos nas reportagens; seguidos por vendavais, com 85 relatos, enxurradas, com 81 relatos; erosão, com 29 relatos; granizo, com 21 relatos; e movimentos de massa, com 6 reportagens (Figuras 36 a 38). Entre os anos estudados, o ano de 2006 apresentou a maior ocorrência de desastres, com 119 relatos nas reportagens.

Com relação às reportagens, foram encontradas 166 ao todo. $O$ ano de 2006 foi o que possui a maior quantidade de reportagens, apresentando 36. 


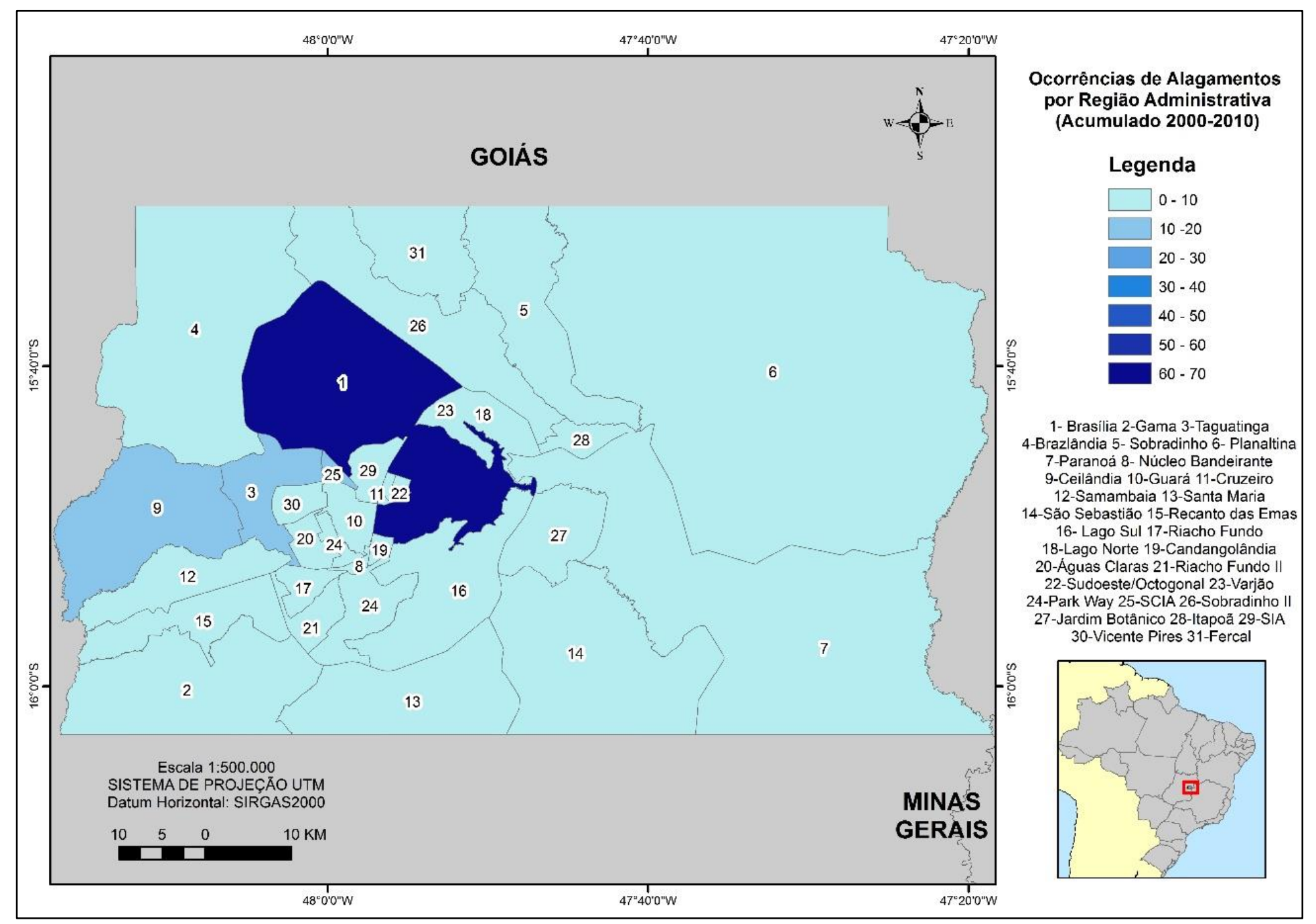

Figura 33. Mapa da ocorrência de alagamentos por Região Administrativa no período de 2000 a 2010. Elaborado por Lucas Garcia Magalhães Peres. 


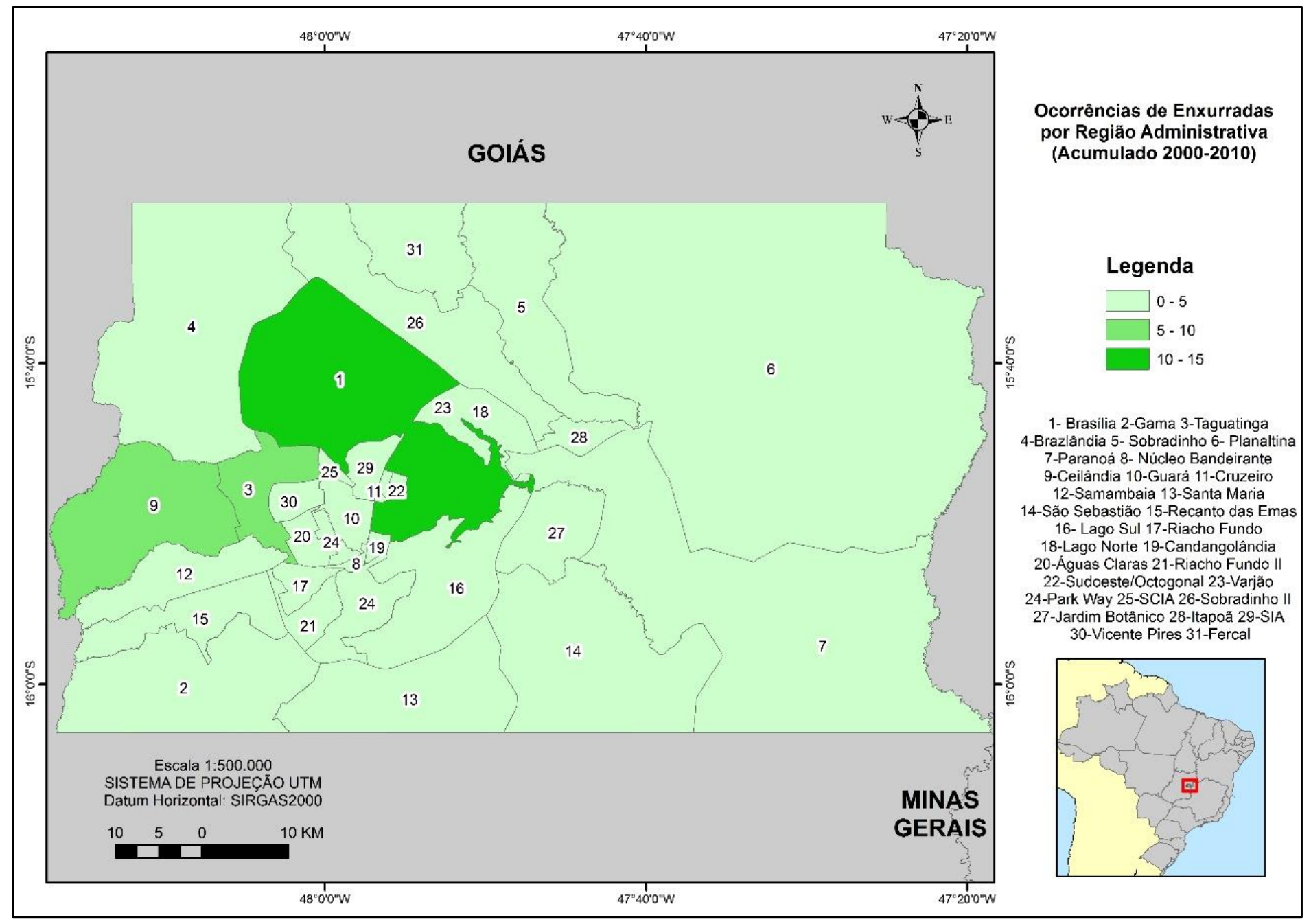

Figura 34. Mapa da ocorrência de enxurradas por Região Administrativa no período de 2000 a 2010. Elaborado por Lucas Garcia Magalhães Peres. 


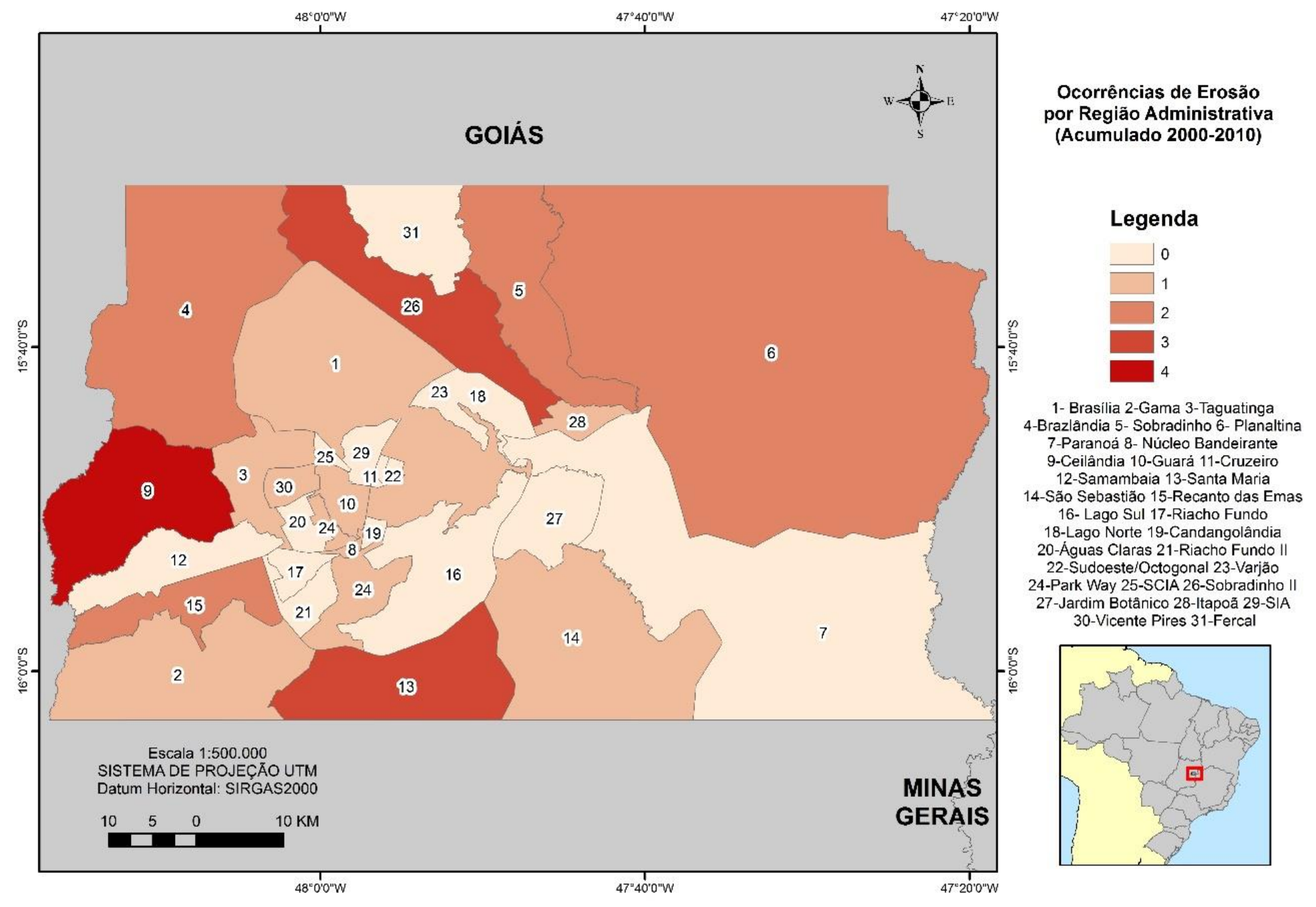

Figura 35. Mapa da ocorrência de erosão por Região Administrativa no período de 2000 a 2010. Elaborado por Lucas Garcia Magalhães Peres. 


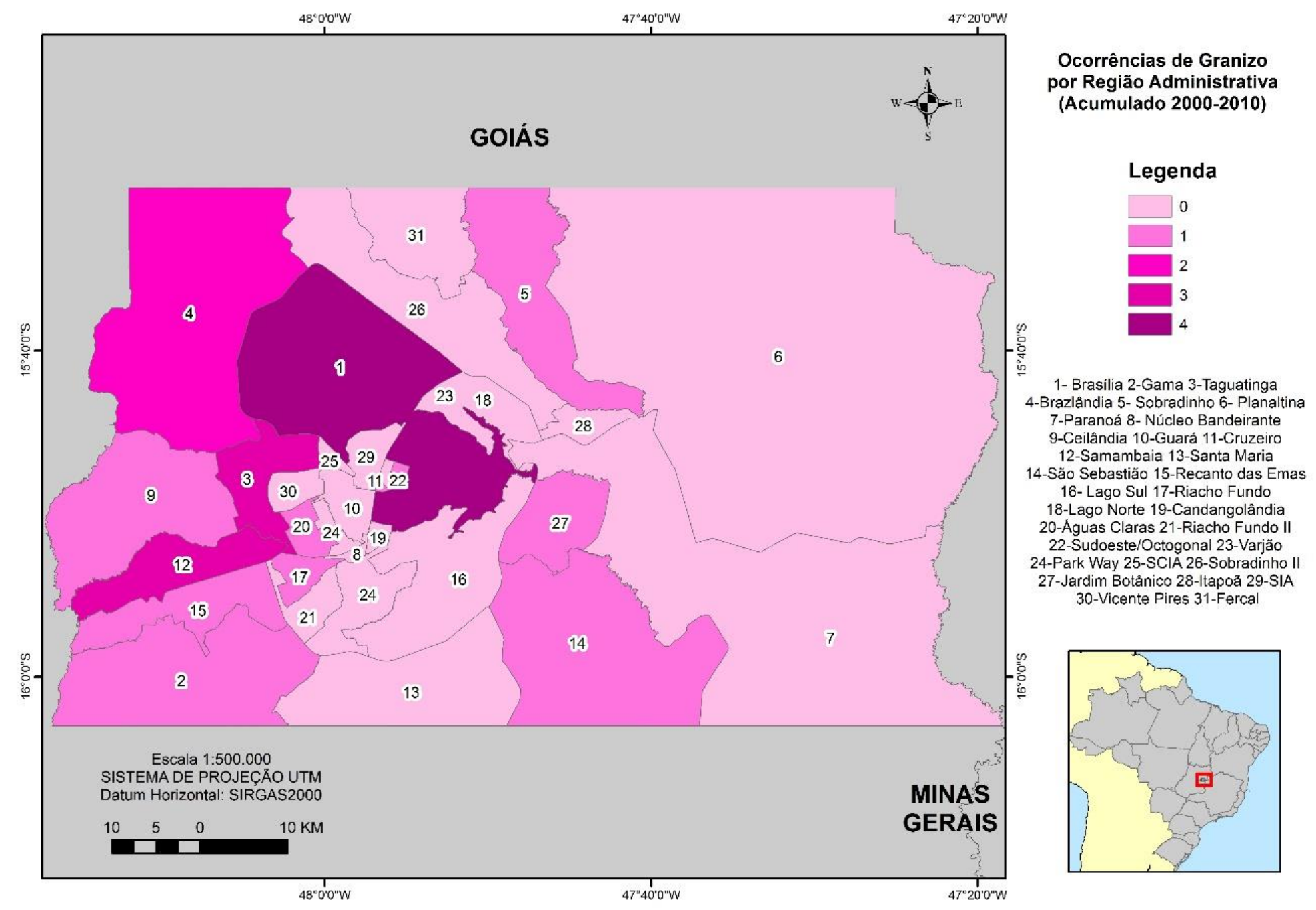

Figura 36. Mapa da ocorrência de granizo por Região Administrativa no período de 2000 a 2010. Elaborado por Lucas Garcia Magalhães Peres. 


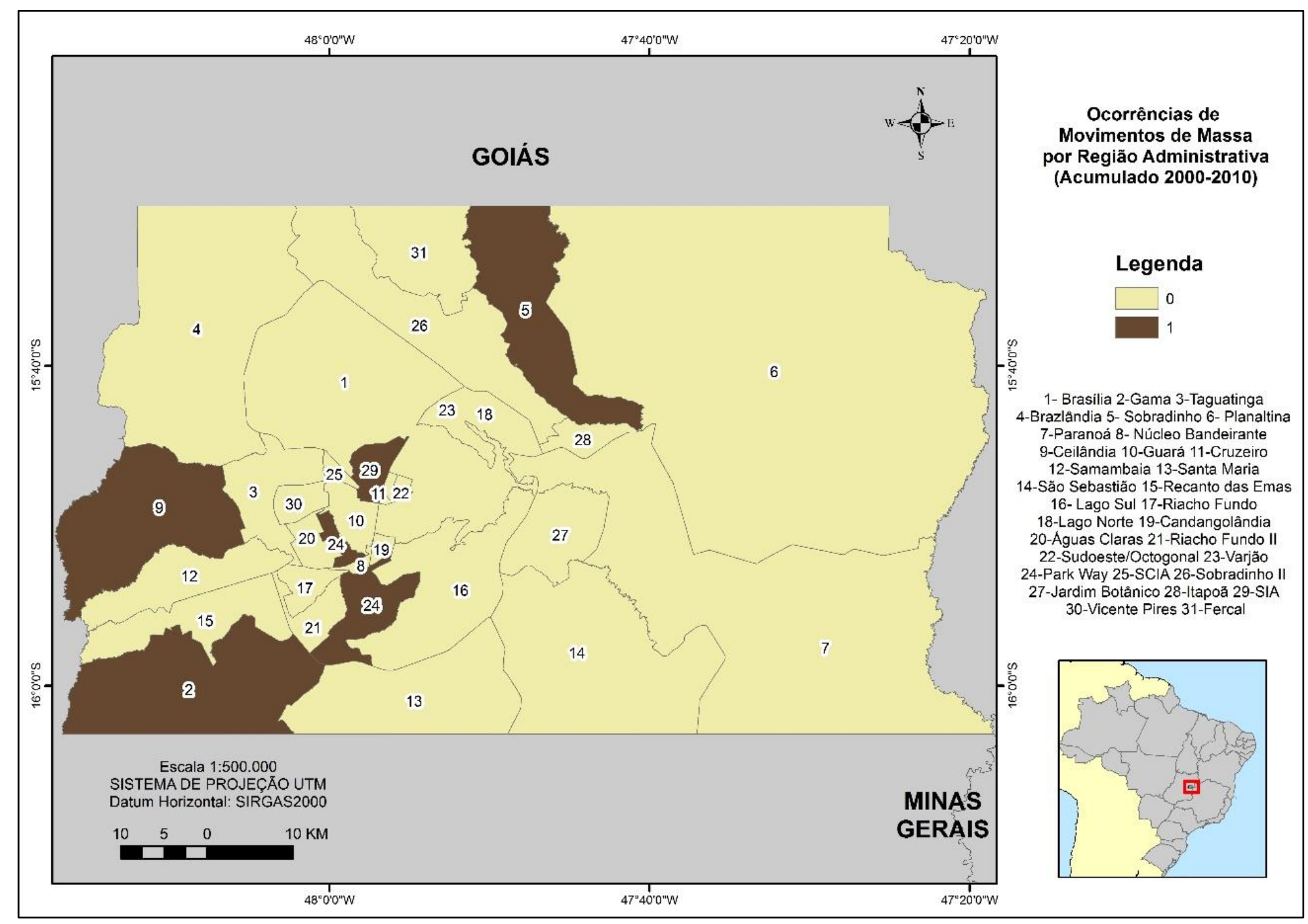

Figura 37. Mapa da ocorrência de movimentos de massa por Região Administrativa no período de 2000 a 2010. Elaborado por Lucas Garcia M. Peres. 


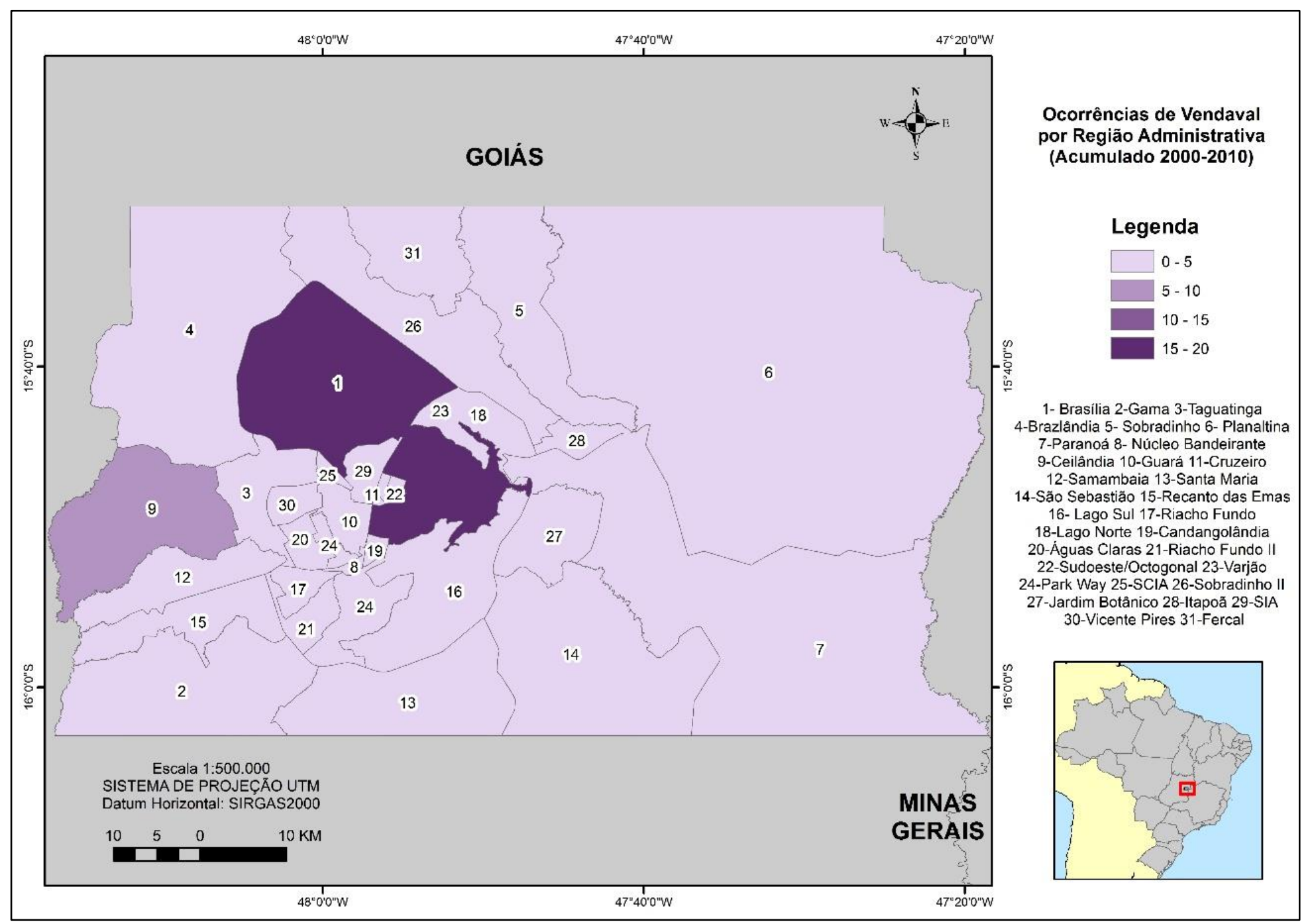

Figura 38. Mapa da ocorrência de vendavais por Região Administrativa no período de 2000 a 2010. Elaborado por Lucas Garcia Magalhães Peres. 


\section{CONCLUSÕES}

A pesquisa revelou que é falsa a noção geral do estabelecida pelo senso comum, pela mídia, pelas diretrizes do Plano Nacional de Riscos e Respostas a Desastres Naturais e em outros documentos que afirmam que o DF passa por poucos desastres naturais. Como podemos ver, mesmo com a cobertura espacial segmentada das reportagens, as mesmas apresentam um montante de dados e informações que permitem afirmar que o número de desastres nas Regiões Administrativas é significativo, mesmo com a pequena área que o DF ocupa no território brasileiro.

Foi alcançado o objetivo de identificar e analisar informações publicadas na mídia impressa referentes aos seguintes desastres naturais: alagamentos, enxurradas, erosões, movimentos de massa, quedas de granizo e vendavais associados a episódios de precipitação entre 2000 e 2010.

A hipótese levantada pelo estudo foi confirmada, o que quer dizer que a expansão urbana com pouco ou nenhum planejamento e infraestrutura préestabelecidos antes da ocupação de áreas é o principal condicionante para ocorrência de desastres naturais no DF, e não as precipitações. Ainda que algumas Regiões Administrativas tenham sido planejadas na sua fundação, como é o caso de Taguatinga (RA III), a sua ocupação e posterior expansão se deu antes da instalação de equipamentos urbanos adequados e suficientes para atender à população. $O$ rápido crescimento populacional do DF num curto período de tempo também neutralizou a capacidade de resposta do poder público, o qual poderia ter tomado medidas para ordenar a ocupação do território.

O meio oficial de coleta e divulgação de informações que poderia servir como ferramenta para a catalogação de desastres em jornais, revistas e outros meios é o S2ID - Sistema Integrado de Informações sobre Desastres, da Secretaria Nacional de Proteção e Defesa Civil (SEDEC) do Ministério da Integração. Atualmente o S2ID se encontra defasado e desatualizado, não servindo ao objetivo da sua criação. Sua cobertura também se mostra limitada, 
focada apenas em estados que historicamente tem maior vulnerabilidade a desastres, como Rio de Janeiro e Santa Catarina.

A atualização desse tipo de banco de dados permitiria, por exemplo, a identificação de áreas mais vulneráveis e com maior ocorrência de desastres, ainda que em geral direcionados pela cobertura midiática. Esse banco de dados, por sua vez, auxiliaria na confecção de mapas de ocorrências de desastres, em diversas escalas, para auxiliar o poder público na prevenção desse fenômeno, na previsão orçamentária e na tomada de decisão.

No Plano Piloto (RA I), área mais afetada pelos desastres encontrados nas reportagens, as iniciativas de reverter o problema de drenagem de águas pluviais tomadas pelo poder público, sobretudo a NOVACAP, esbarram na maioria das vezes em questões legais, como a aprovação das obras pelo IPHAN (Instituto do Patrimônio Histórico e Artístico Nacional), já que a área é tombada pela Organização das UNESCO (Organização das Nações Unidas para a Educação, Ciência e Saúde). Intervenções urbanas até para obras relativamente mais simples, como a criação de baciões nas vias, acabam não sendo aprovadas por alterarem o projeto urbanístico da capital.

Na Ceilândia (RA XI), cujo início se deu em Taguatinga (RA III) área do Centro de Erradicação de Invasões (CEI) das vilas irregulares que se localizavam próximas ao Plano Piloto, é visível que a resiliência da população aos desastres naturais é menor. Além de crescer urbana e demograficamente de forma célere, se tornando maior até do que a própria Taguatinga que the deu origem, a proximidade com áreas ambientalmente vulneráveis, como encostas, acarretou a ocorrência de diversos desastres, sobretudo nas áreas dos condomínios Privê e Sol Nascente, que surgiram como invasões e logo depois começaram a ser regularizadas pelo poder público.

Para minimizar os efeitos negativos dos desastres naturais associados às chuvas recomenda-se algumas ações:

- ampliação e aumento da efetividade da rede pública de transportes do DF, para atrair mais passageiros e reduzir o número de veículos em 
circulação, o que consequentemente reduziria também os acidentes de trânsito, melhorando a circulação de veículos;

- descentralização dos órgãos e repartições públicas do Plano Piloto, para diminuir o deslocamento diário e mútuo da maioria dos trabalhadores do DF, o que melhoraria a fluidez do trânsito nos horários de pico e ajudaria a desenvolver outras Regiões Administrativas do DF;

- fiscalização rigorosa das áreas de ocupação e expansão urbana no DF por parte do poder público, levando em conta que a maioria das áreas de expansão da cidade estão sobre espaços de recarga dos mananciais e de infiltração da água das chuvas. A reposição da água pelo lençol freático é prejudicada, o que futuramente pode ocasionar problemas de abastecimento.

Identificados os desastres naturais e descoberta as áreas de maior ocorrência localização, recomenda-se dar continuidade às pesquisas neste tema, para se descobrir por exemplo qual o impacto que os desastres naturais geram à economia do DF. Outra alternativa é utilizar o estudo com a mídia para identificação e prevenção de desastres como ferramenta pedagógica no ensino de Geografia.

Conclui-se com esse estudo que as precipitações, na maioria das vezes, não são as principais catalisadoras / causadoras de desastres naturais, como é amplamente noticiado pela mídia. O planejamento inicial que se deu para a construção da capital não abarcou a possibilidade de crescimento populacional e expansão urbana se dessem numa velocidade maior que o suportado para o que foi planejado, e logo o DF ultrapassou cinco vezes o número de habitantes proposto em seu plano original, que era de 500 mil habitantes. As iniciativas do poder público tomadas até recentemente carecem de coordenação interna e da falta de investimentos que tem afetado os governos recentes. É importante sempre se ressaltar que não cabe somente ao poder público isoladamente tomar medidas para prevenir os desastres naturais. A sociedade tem sua parcela de responsabilidade no aumento dos riscos de desastres, mas pode e deve ser conscientizada que a ocupação de áreas irregulares, o descarte 
inadequado de resíduos sólidos, dentre outras coisas que poderiam ser citadas, contribuem para sua tornar sua própria situação vulnerável.

\section{REFERÊNCIAS BIBLIOGRÁFICAS}

AHCHONG, Katrina; DODDS, Rachel. Anthropogenic climate change coverage in two Canadian newspapers, the Toronto Star and the Globe and Mail, from 1988 to 2007. Environmental Science \& Policy, v. 15, n. 1, p. 48-59, 2012.

AMARAL, Rosangela do; GUTJAHR, Mirian Ramos. Cadernos de educação ambiental: Desastres naturais. São Paulo: Instituto Geológico / Secretaria do Meio Ambiente, v. 8, 2011.

ANTILLA, Liisa. Climate of scepticism: US newspaper coverage of the science of climate change. Global environmental change, v. 15, n. 4, p. 338-352, 2005.

ANTILLA, Liisa. Self-censorship and science: a geographical review of media coverage of climate tipping points. Public Understanding of Science, 2010.

ARMOND, Nubia Beray; SANT'ANNA NETO, João Lima. Utilização de mídia impressa na identificação e análise de episódios extremos de chuva no município do Rio de Janeiro. Revista GeoNorte, v. 1, p.774-785, 2012.

ARMOND, Núbia Beray. Entre eventos e episódios: as excepcionalidades das chuvas e os alagamentos no espaço urbano no Rio de Janeiro. 2014. 239 f. Dissertação (Mestrado em Geografia) - Faculdade de Ciências e Tecnologia da Universidade Estadual Paulista Júlio de Mesquita Filho, Presidente Prudente, 2014.

ANGUELOVSKI, Isabelle; CARMIN, JoAnn. Something borrowed, everything new: innovation and institutionalization in urban climate governance. Current Opinion in Environmental Sustainability, v. 3, n. 3, p. 169-175, 2011.

BANISTER, David. Cities, mobility and climate change. Journal of Transport Geography, v. 19, n. 6, p. 1538-1546, 2011.

BARRETO, Raquel. Identificação de áreas susceptíveis a eventos extremos de chuva no Distrito Federal. Brasília, 2008. Dissertação (Mestrado em Geografia), Instituto de Ciências Humanas, Departamento de Geografia, Universidade de Brasília.

BARROS, J. R. A chuva no Distrito Federal: 0 regime $e$ as excepcionalidades do ritmo. Rio Claro, 2003. Dissertação (Mestrado em 
Geografia), Instituto de Geociências e Ciências Exatas, Departamento de Geografia, Universidade Estadual Paulista. 2003.

BILLETT, Simon. Dividing climate change: global warming in the Indian mass media. Climatic change, v. 99, n. 1-2, p. 1-16, 2010.

BOYKOFF, Maxwell T.; BOYKOFF, Jules M. Balance as bias: global warming and the US prestige press. Global environmental change, v. 14, n. 2, p. 125136, 2004.

BOYKOFF, Maxwell T.; BOYKOFF, Jules M. Climate change and journalistic norms: A case-study of US mass-media coverage. Geoforum, v. 38, n. 6, p. 1190-1204, 2007.

BOYKOFF, Maxwell T. The cultural politics of climate change discourse in UK tabloids. Political Geography, v. 27, n. 5, p. 549-569, 2008.

BOYKOFF, Maxwell T.; MANSFIELD, Maria. 'Ye Olde Hot Aire': reporting on human contributions to climate change in the UK tabloid press. Environmental Research Letters, v. 3, n. 2, p. 024002, 2008.

BRANDÃO, A. M. de P. M. O clima urbano da cidade do Rio de Janeiro. São Paulo, 1996. Tese (Doutorado em Geografia), Departamento de Geografia, Universidade de São Paulo. 1996.

BRASIL. Constituição (1891). Constituição dos Estados Unidos do Brasil: promulgada em 24 de fevereiro de 1891. Disponível em: <http://www.planalto.gov.br/ccivil 03/constituicao/constitui\%C3\%A7ao91.htm>.

BRASIL. Constituição (1946). Constituição dos Estados Unidos do Brasil: promulgada em 18 de setembro de 1946. Disponível em: <http://www.planalto.gov.br/ccivil 03/constituicao/constitui\%C3\%A7ao46.htm>.

BRASIL. Lei oㅜ 1803, de 5 de janeiro de 1953. Autoriza o Poder Executivo a realizar estudos definitivos sobre a localização da nova Capital da República. Diário Oficial da União. Seção 1. 08/01/1953. p. 347.

BRASIL. Ministério da Ciência e Tecnologia / Ministério das Relações Exteriores. Protocolo de Quioto (tradução). Quioto: 2001. Disponível em: < http://www.mct.gov.br/upd_blob/0012/12425.pdf>. Acesso em: 14 de novembro de 2015.

BRASIL. Ministério da Integração Nacional. Secretaria Nacional de Defesa Civil. Centro Nacional de Gerenciamento de Riscos e Desastres. Anuário Brasileiro de Desastres Naturais: 2011. Brasília: CENAD, 2012. 
BRASIL. Ministério da Integração Nacional. Secretaria Nacional de Defesa Civil. Centro Nacional de Gerenciamento de Riscos e Desastres. Anuário Brasileiro de Desastres Naturais: 2012. Brasília: CENAD, 2013.

BRASIL. Ministério da Integração Nacional. Secretaria Nacional de Defesa Civil. Centro Nacional de Gerenciamento de Riscos e Desastres. Anuário Brasileiro de Desastres Naturais: 2013. Brasília: CENAD, 2014.

BRASIL. Ministério de Integração de Nacional. Secretaria Nacional de Defesa Civil. Banco de Desastres Naturais: sistema integrado de informações sobre desastres - S2ID. 2015. Disponível em: <http://s2id.integracao.gov.br/>. Acesso em: nov. 2015.

BROWN, T.; BUDD, L.; BELL, M.; \& RENDELL, H. The local impact of global climate change: reporting on landscape transformation and threatened identity in the English regional newspaper press. Public Understanding of Science, $v$. 20, n. 5, p. 658-673, 2011.

CAMBRA, Marcus Felipe Emerick Soares; COELHO NETTO; Ana Luiza. A cidade do Rio de Janeiro e as chuvas de março-93: organização urbana e inundações. Anuário do Instituto de Geociências. v. 20. p. 55-74. 1997.

CAMPOS, José Eloi Guimarães. Hidrogeologia do Distrito Federal: bases para a gestão dos recursos hídricos subterrâneos. Revista Brasileira de

Geociências, v. 34, n. 1, p. 41-48, 2004.

CARPINTERO, Antônio Carlos Cabral. Brasília, prática e teoria urbanística no Brasil 1956-1998. São Paulo, 1998. Tese (Doutorado em Arquitetura e Urbanismo), Faculdade de Arquitetura e Urbanismo, Universidade de São Paulo.

CEPED (Centro Universitário de Estudos e Pesquisas sobre Desastres). Universidade Federal de Santa Catarina. Atlas Brasileiro de Desastres Naturais: 1991 a 2012. 2. ed. Florianópolis: CEPED, 2013.

CHAKRABARTY, Bikas K. Urban management: concepts, principles, techniques and education. Cities, v. 18, n. 5, p. 331-345, 2001.

CHERRY, C.; HOPFE, C.; MACGILLIVRAY, B.; PIDGEON, N. Media discourses of low carbon housing: The marginalisation of social and behavioural dimensions within the British broadsheet press. Public Understanding of Science, v. 24, n. 3, p. 302-310, 2015.

CHOI, J.; YANG, M.; CHANG, J. Elaboration of the hostile media phenomenon the roles of involvement, media skepticism, congruency of perceived media 
influence, and perceived opinion climate. Communication Research, v. 36, n. 1, p. 54-75, 2009.

CODEPLAN. Pesquisa distrital por amostra de municípios: Distrito Federal. Brasília: Secretaria de Planejamento do Governo do Distrito Federal, 2011. Disponível em: <

http://www.codeplan.df.gov.br/images/CODEPLAN/PDF/Pesquisas\%20Socioec on\%C3\%B4micas/PDAD/2012/PDAD-DF-2011-091112.pdf>. Acesso em: dez. 2015.

COELHO, Lucas Lima; PERES, Lucas Garcia Magalhães; STEINKE, Ercília Torres. Impactos pluviais e suas implicações no Distrito Federal no ano chuvoso de 2006. In: CONGRESSO IBEROAMERICANO DE ESTUDOS TERRITORIAIS E AMBIENTAIS, 6., 2014. Anais... São Paulo: Universidade de São Paulo, 2014, p. 2651-2669.

COELHO, L. L.; TAVEIRA, I. A. P.; STEINKE, E. T. Impactos pluviais do ano chuvoso de 1992 e suas consequências no Distrito Federal, Brasil. Anales del 14ํ Encuentro de Geógrafos de América Latina - Reencuentro de Saberes Territoriales Latinoamericanos. Lima: Unión Geográfica Internacional Comité Nacional Perú, v.1, 2013.

COOPER, Caren B. Media literacy as a key strategy toward improving public acceptance of climate change science. BioScience, v. 61, n. 3, p. 231-237, 2011.

COSTA, Graciete Guerrra da. As regiões administrativas do Distrito Federal de 1960 a 2011. Brasília, 2011. Tese (Doutorado em Arquitetura e Urbanismo), Faculdade de Arquitetura e Urbanismo, Departamento de Teoria e História, Universidade de Brasília.

CRULS, Luis. Relatório da Comissão Exploradora do Planalto Central do Brasil: Relatório Cruls. Brasília: CODEPLAN (Companhia do Desenvolvimento do Planalto Central), 1992.

DADDOW, Oliver. The UK media and 'Europe': from permissive consensus to destructive dissent. International Affairs, v. 88, n. 6, p. 1219-1236, 2012.

DIFRANCESCO, Darryn Anne; YOUNG, Nathan. Seeing climate change: The visual construction of global warming in Canadian national print media. Cultural Geographies, v. 18, n. 4, p. 517-536, 2011.

DOULTON, Hugh; BROWN, Katrina. Ten years to prevent catastrophe?:

Discourses of climate change and international development in the UK press.

Global Environmental Change, v. 19, n. 2, p. 191-202, 2009. 
EIDE, Elisabeth; YTTERSTAD, Andreas. The tainted hero: Frames of domestication in Norwegian press representation of the Bali climate summit. The International Journal of Press/Politics, v. 16, n. 1, p. 50-74, 2011.

ELY, Deise Fabiana. Aquecimento global e mudanças climáticas na mídia impressa: um debate científico?. In: KATUTA, A. M; ELY, D. F.; PAULINO, E. T; CUNHA, P. C. A.; ANTONELLO, I. T. (Org.). Geografia e mídia impressa. 1. ed. Londrina: Moriá, 2009.

EM-DAT. The Internacional Disaster Database. The Office of United States Foreign Disaster Assistance (OFDA) / Centre for Research on the Epidemiology of Disasters (CRED) International Disaster Database. Disponível em: <http://www.em-dat.net/>. Acesso em: nov. 2015.

FORD, James D.; KING, Diana. Coverage and framing of climate change adaptation in the media: A review of influential North American newspapers during 1993-2013. Environmental Science \& Policy, v. 48, p. 137-146, 2015.

FRANZÃO NETO, Ângelo. Midialização: o poder da mídia. São Paulo: Nobel, 2006.

FIALHO, Edson Soares. Climatologia e desastres ambientais: A demanda dos recursos públicos após o espetáculo midiático. Revista Tamoios, v. 9, n. 1, 2013.

GAILLARD, Jean-Christophe; TEXIER, Pauline. Religions, natural hazards, and disasters: An introduction. Religion, v. 40, n. 2, p. 81-84, 2010.

GAVIN, Neil T.; LEONARD-MILSOM, Liam; MONTGOMERY, Jessica. Climate change, flooding and the media in Britain. Public Understanding of Science, v. 20 , n. 3 , p. $422-438,2011$.

GUHA-SAPIR-, D.; HARGITT, D.; HOYOIS, P. Thirty years of Natural Disasters 1974-2003: the numbers. Bruxelas: Presses de l'Universite' Catholique de Louvain, 2004.

GONÇALVES, Neyde M. Santos. Impactos pluviais e desorganização do espaço urbano em Salvador. In: MONTEIRO, Carlos A. F; MENDONÇA, Francisco. Clima Urbano. São Paulo: Editora Contexto, p.69-91, 2003.

GRIMMOND, C.; ROTH, M.; OKE, T.; AU, Y.; BEST, M.; BETTS, R.; CARMICHAEL, G.; CLEUGH, H.; DABBERDT, W.; EMMANUEL, R.; FREITAS, E.; FORTUNIAK, K.; HANNA, S.; KLEIN, P.; KALKSTEIN, L.; LIU, C.; NICKSON, A.; PEARLMUTTER, D; SAILOR, D.; VOOGT, J. Climate and more sustainable cities: climate information for improved planning and management 
of cities (producers/capabilities perspective). Procedia Environmental

Sciences, v. 1, p. 247-274, 2010.

GUNTHER, A.; CHRISTEN, C.; LIEBHART, J. L.; CHIA, S. Congenial public, contrary press, and biased estimates of the climate of opinion. Public Opinion Quarterly, v. 65, n. 3, p. 295-320, 2001.

HALLEGATTE, Stéphane; DUMAS, Patrice. Can natural disasters have positive consequences? Investigating the role of embodied technical change. Ecological Economics, v. 68, n. 3, p. 777-786, 2009.

HALLEGATTE, S.; RANGER, N.; MESTRE, O.; DUMAS, P.; CORFEE-

MORLOT, J.; HERWEIJER, C.; WOOD, R.. Assessing climate change impacts, sea level rise and storm surge risk in port cities: a case study on Copenhagen.

Climatic change, v. 104, n. 1, p. 113-137, 2011.

HEWITT, K. The idea of calamity in a technocratic age. In: HEWITT, K. (Ed.) Interpretations of calamity: from the view point of ecology. London: Allen and Unwin, 1983. p.3-32.

IBGE. Estados@. Brasília: 2015. Disponível em: < http://www.ibge.gov.br/estadosat/perfil.php?sigla=df>. Acesso em: nov. 2015.

INMET. 2009. Normais Climatológicas do Brasil (1961-1990). Org.: RAMOS, A. M.; SANTOS, L. A. R.; FORTES, L. T. G. Brasília: 2009.

INMET / INPE - CPTEC. INFOCLIMA - Boletim de informações climáticas. Disponível em: <http://infoclima.cptec.inpe.br/>. Acesso em: agosto de 2016. JASPAL, Rusi; NERLICH, Brigitte; KOTEYKO, Nelya. Contesting science by appealing to its norms: Readers discuss climate science in the Daily Mail. Science Communication, p. 383-410, 2012.

JASPAL, Rusi; NERLICH, Brigitte. When climate science became climate politics: British media representations of climate change in 1988. Public Understanding of Science, p. 122-141, 2012.

KENIX, Linda Jean. Framing science: Climate change in the mainstream and alternative news of New Zealand. Political Science, v. 60, n. 1, p. 117-132, 2008.

KHASNIS, A.; NETTLEMAN, M. Global warming and infectious disease. Archives of medical research, v. 36, n. 6, p. 689-696, 2005.

KOBIYAMA, Masato (org.). Prevenção de desastres naturais: conceitos básicos. Curitiba: Organic Trading, 2006. 
LEITE, José Correa. Controvérsias na Climatologia: o IPCC e o aquecimento global antropogênico. Scientiae Studia, v. 13, n. 3, p. 643-677, 2015.

LIU, Xinsheng; VEDLITZ, Arnold; ALSTON, Letitia. Regional news portrayals of global warming and climate change. Environmental science \& policy, v. 11, n. 5, p. 379-393, 2008.

LYYTIMÄKI, Jari. Mainstreaming climate policy: the role of media coverage in Finland. Mitigation and Adaptation Strategies for Global Change, v. 16, n. 6 , p. 649-661, 2011.

MARCELINO, Emerson Vieira; NUNES, Lucí Hidalgo; KOBIYAMA, Masato. Banco de dados de desastres naturais: análise de dados globais e regionais. Caminhos de Geografia, v. 7, n. 19, 2006.

MARTINS, E. S.; BAPTISTA, G. M. M. Compartimentação geomorfológica e sistemas morfodinâmicos do Distrito Federal. In: Inventário hidrogeológico e dos recursos hídricos superficiais do Distrito Federal. Brasília: IEMA / SEMATEC / Universidade de Brasília, 1998, v. 1. p. 88-137.

MARTINS, E. S.; REATTO, A.; CARVALHO JÚNIOR, O. A.; GUIMARÃES, R. F. Evolução geomorfológica do Distrito Federal. Documentos EMBRAPA Cerrados. Planaltina: Embrapa Cerrados, n. 122, 2004.

MCBEAN, G. Climate change and extreme weather: a basis for action. Natural Hazards, v. 31, p. 177-190, 2004.

MCGILL, Ronald. Urban management in developing countries. Cities, v. 15, n. 6, p. 463-471, 1998.

MILLS, G.; CLEUGH, H.; EMMANUEL, R.; ENDLICHER, W.; ERELL, E.; MCGRANAHAN, G.; NG, E.; NICKSON, A.; ROSENTHAL, J.; STEEMER, $K$. Climate information for improved planning and management of mega cities (needs perspective). Procedia Environmental Sciences, v. 1, p. 228-246, 2010.

MONTEIRO, Carlos Augusto de Figueiredo. A frente polar atlântica e as chuvas de inverno na fachada sul-oriental do Brasil: contribuição metodológica à análise rítmica dos tipos de tempo no Brasil. Série teses e monografias, v. 1, Instituto de Geografia, Universidade de São Paulo, São Paulo, 1969.

NIMER, Edmond. Climatologia do Brasil. Rio de Janeiro: IBGE (série Recursos Naturais e Meio Ambiente), 1989.

NOVAES, Washington. Agenda 21: um novo modelo de civilização. Brasília: Caderno de Debate e Sustentabilidade, Ministério do Meio Ambiente, 2003. 
ORGANIZAÇÃO DAS NAÇÕES UNIDAS (ONU). World Economic and Social Survey 2008: Overcoming Economic Insecurity. Organização das Nações Unidas: Departamento de Assuntos Econômicos e Sociais, New York, 2008.

PASQUARÉ, Federico A.; OPPIZZI, Paolo. How do the media affect public perception of climate change and geohazards? An Italian case study. Global and Planetary Change, v. 90, p. 152-157, 2012.

PATENAUDE, Genevieve. Climate change diffusion: while the world tips, business schools lag. Global Environmental Change, v. 21, n. 1, p. 259-271, 2011.

POBEREZHSKAYA, Marianna. Media coverage of climate change in Russia: Governmental bias and climate silence. Public Understanding of Science, p. 96-111, 2014.

REUTERS, Thomson. Web of Science (website). Disponível em: $<$ https://www.webofknowledge.com>. Acesso em: out. 2015.

RUSSILL, Chris; NYSSA, Zoe. The tipping point trend in climate change communication. Global Environmental Change, v. 19, n. 3, p. 336-344, 2009.

SAMPEI, Yuki; AOYAGI-USUI, Midori. Mass-media coverage, its influence on public awareness of climate-change issues, and implications for Japan's national campaign to reduce greenhouse gas emissions. Global

Environmental Change, v. 19, n. 2, p. 203-212, 2009.

SEMARH. Mapa Ambiental do Distrito Federal. Brasília: SEMARH, 2000. Escala: 1:100.000. 1 CD-ROM.

SCHÄFER, Mike S.; IVANOVA, Ana; SCHMIDT, Andreas. What drives media attention for climate change? Explaining issue attention in Australian, German and Indian print media from 1996 to 2010. International Communication Gazette, v. 76, n. 2, p. 152-176, 2014.

SCHMIDT, Andreas; IVANOVA, Ana; SCHÄFER, Mike S. Media attention for climate change around the world: A comparative analysis of newspaper coverage in 27 countries. Global Environmental Change, v. 23, n. 5, p. 12331248, 2013.

SIDLE, R. C.; TAYLOR, D.; LU, X. X.; ADGER, W. N.; LOWE, D. J.; LANGE, W. P.; NEWNHAM, R. M.; DODSON, J. R. Interactions of natural hazards and society in Austral-Asia: evidence in past and recent records. Quaternary International, n.118-119, p.181-203, 2004.

SILVA, A. M.; SCHULZ, H. E.; CAMARGO, P. B. Erosão e hidrossedimentologia em bacias hidrográficas. São Carlos: RiMa, 2003. 
SILVA, José Graziano da. A modernização dolorosa: estrutura agrária, fronteira agrícola e trabalhadores rurais no Brasil. Rio de Janeiro: Zahar Editores, 1982.

SINCLAIR, M. R.; WATTERSON, I. G. Objective assessment of extratropical weather systems in simulated climates. Journal of Climate, v. 12, p. 34673485, 1999.

SOUZA, Camila Grosso de. A influência do ritmo climático na morbidade respiratória em ambientes urbanos. Presidente Prudente, 2007. Dissertação (Mestrado em Geografia) Faculdade de Ciências e Tecnologia, Universidade Estadual Paulista Júlio de Mesquita Filho. 2007.

STEINKE, V. A. Uso integrado de dados digitais morfométricos (altimetria e sistema de drenagem) na definição de unidades geomorfológicas no Distrito Federal. Brasília. Tese de Doutorado. Dissertação (Mestrado em Geologia) Instituto de Geociências, Universidade de Brasília, 2003.

STEINKE, Ercília Torres. Considerações sobre a variabilidade e mudança climática no Distrito Federal, suas repercussões nos recursos hídricos e informação ao grande público. Brasília, 2004. Tese (Doutorado em Ecologia) - Instituto de Ciências Biológicas, Universidade de Brasília. 2004.

STEINKE, E. T.; SAITO, C. H.; ANDRADE, G. S.; GASPAR, L. Como a mídia impressa do Distrito Federal divulga fatos relacionados ao clima e ao tempo na época de estiagem. Geografia, Rio Claro, v. 31, n. 2, p. 347-357, mai./ago. 2006.

STEINKE, E. T.; REZENDE, M. S.; CAVALCANTI, L. Sistemas geradores de eventos extremos de precipitação em outubro de 2006 no Distrito Federal: uma análise geográfica dos desastres. Revista Brasileira de Climatologia. São Paulo: v. 2, p. 23-34. dez. 2006.

STEINKE, V. A. Uso integrado de dados digitais morfométricos (altimetria e sistema de drenagem) na definição de unidades geomorfológicas no Distrito Federal. Brasília, 2003. Dissertação (Mestrado em Geologia) - Instituto de Geociências, Universidade de Brasília. 2003.

STRAHLER, A. N.; STRAHLER, A. H. Geografia Física. Barcelona: Omega, 1989.

TAKAHASHI, Bruno; MEISNER, Mark. Climate change in Peruvian newspapers: The role of foreign voices in a context of vulnerability. Public Understanding of Science, p. 427-442, 2012. 
TAVARES, Érico Neiva. Principais problemas causados à população de Brasília por precipitação nos períodos de 1982 a 1992 e de 1999 a 2005. Brasília, 2008. Monografia (Graduação em Geografia), Instituto de Ciências Humanas, Universidade de Brasília. 2008.

VAN DE VLIERT, Evert. Bullying the Media: Cultural and Climato-Economic Readings of Press Repression versus Press Freedom. Applied Psychology, v. 60, n. 3, p. 354-376, 2011.

VEYRET, Yvette. Os riscos: o homem como agressor e vítima do meio ambiente. São Paulo: Editora Contexto, 2007.

WERNA, Edmundo. The management of urban development, or the development of urban management? Problems and premises of an elusive concept. Cities, v. 12, n. 5, p. 353-359, 1995.

WHITE, G. F. Natural hazards research: concepts, methods and policy implications. In: WHITE, G. F. Natural hazards: local, national, global. New York: Oxford University Press, 1974, p. 3-16.

YOUNG, Nathan. Working the fringes: the role of letters to the editor in advancing non-standard media narratives about climate change. Public Understanding of Science, v. 22, n. 4, p. 443-459, 2013.

ZAMITH, Rodrigo; PINTO, Juliet; VILLAR, Maria Elena. Constructing Climate Change in the Americas An Analysis of News Coverage in US and South American Newspapers. Science Communication, v. 35, n. 3, p. 334-357, 2013.

ZANELLA, Maria Elisa. Inundações urbanas em Curitiba/PR: Impactos, riscos e vulnerabilidade socioambiental no bairro do Cajuru. Curitiba, 2006. Tese (Doutorado em Meio Ambiente e Desenvolvimento), Universidade Federal do Paraná. 2006.

ZAVATTINI, João Affonso. A Climatologia Geográfica Brasileira, o enfoque dinâmico e a noção de ritmo climático: desenvolvimento, progresso e perspectivas. Boletim Climatológico, Presidente Prudente, v. 1, n. 2, p. 11-20, 1996.

ZAVATTINI, João Affonso. A produção brasileira em climatologia: o tempo e o espaço nos estudos do ritmo climático. Terra Livre, São Paulo, v. 1, n. 20, p. 66-99, 2003.

ZHANG, Z.; TIAN, H; CAZELLES, B.; KAUSRUD, K. L.; BRÄUNING, A.; GUO, F. STENSETH, N. C. Periodic climate cooling enhanced natural disasters and 
wars in China during AD 10-1900. Proceedings of the Royal Society of London: Biological Sciences, n. 277, p. 3745-3753, 2010. 


\section{APÊNDICES}




\section{APÊNDICE I}

\section{Desastres Naturais relacionados às chuvas no Distrito Federal relatados no jornal Correio Braziliense no ano de 2000}

Janeiro

\begin{tabular}{|c|c|c|c|}
\hline \multicolumn{4}{|c|}{ Notícia nำ 1} \\
\hline Dia: 07 & Página: - & Caderno: Cidades & Possui Fotos: Sim \\
\hline \multicolumn{4}{|c|}{ Título: A chuva encharca a miséria } \\
\hline \multicolumn{4}{|c|}{$\begin{array}{l}\text { Informações adicionais: A chuva forte castigou uma invasão no Recanto das Emas, } \\
\text { causando enxurradas que inundaram várias casas e aumentaram erosões da região. }\end{array}$} \\
\hline \multicolumn{4}{|c|}{ Desastre(s) Natural(is) associado à reportagem: Enxurradas, erosão. } \\
\hline \multicolumn{4}{|c|}{ Região(ões) Administrativa(s) afetada(s): Recanto das Emas (RA XV). } \\
\hline \multicolumn{4}{|c|}{$\begin{array}{l}\text { Referência bibliográfica: ABREU, Marcelo. A chuva encharca a miséria. Correio } \\
\text { Braziliense, Brasília, } 07 \text { de jan. de } 2000 \text {. Cidades. }\end{array}$} \\
\hline
\end{tabular}

\begin{tabular}{|c|c|c|c|}
\hline \multicolumn{4}{|c|}{ Notícia no 2} \\
\hline Dia: 18 & Página: - & Caderno: Cidades & Possui Fotos: Sim \\
\hline \multicolumn{4}{|c|}{ Título: Chuvas alagam Brazlândia } \\
\hline \multicolumn{4}{|c|}{$\begin{array}{l}\text { Informações adicionais: Cerca de } 100 \text { casas ficaram alagadas no forte temporal que } \\
\text { caiu sobre Brazlândia, causando muitos danos materiais. }\end{array}$} \\
\hline \multicolumn{4}{|c|}{ Desastre(s) Natural(is) associado(s) à reportagem: Alagamento, enxurrada. } \\
\hline \multicolumn{4}{|c|}{ Região(ões) Administrativa(s) afetada(s): Brazlândia (RA IV). } \\
\hline $\begin{array}{l}\text { Referênci } \\
\text { Braziliens }\end{array}$ & $\begin{array}{l}\text { liográfica: } \\
\text { sília, } 18 \text { de }\end{array}$ & $\begin{array}{l}\text { IRO, Luciana. Chuv } \\
\text { 2000. Cidades, s. p. }\end{array}$ & Brazlândia. Correio \\
\hline
\end{tabular}

\begin{tabular}{|c|c|c|c|}
\hline \multicolumn{4}{|c|}{ Notícia n 3} \\
\hline Dia: 19 & Página: - & Caderno: Últimas & Possui Fotos: Sim \\
\hline \multicolumn{4}{|c|}{ Título: Chuva provoca estragos no DF } \\
\hline
\end{tabular}


Companhia Energética de Brasília (CEB), o que levou à falta de energia elétrica nessas Regiões Administrativas.

Desastre(s) Natural(is) associado(s) à reportagem: Enxurrada, vendaval.

Região(ões) Administrativa(s) afetada(s): Taguatinga (RA III), Ceilândia (RA IX), Samambaia (RA XII).

Referência bibliográfica: REDAÇÃO. Chuva provoca estragos no DF. Correio Braziliense, Brasília, 19 de jan. de 2000. Últimas, s. p.

\begin{tabular}{|c|c|c|c|}
\hline \multicolumn{4}{|c|}{ Notícia n 4} \\
\hline Dia: 20 & Página: - & Caderno: Cidades & Possui Fotos: Sim \\
\hline \multicolumn{4}{|c|}{ Título: Temporal foi rápido e destruidor } \\
\hline \multicolumn{4}{|c|}{$\begin{array}{l}\text { Informações adicionais: Chuva forte deixou casas inundadas, lama nas ruas, árvores } \\
\text { derrubadas e muita gente sem energia elétrica em Ceilândia, Recanto das Emas, } \\
\text { Samambaia e Taguatinga. No Centro de Ensino 18, na Ceilândia, duas partes do muro } \\
\text { da escola caíram. Um homem foi carregado pela enxurrada quando tentava ajudar um } \\
\text { colega na QNM } 20 \text { de Taguatinga e } 30 \text { casas ficaram destelhadas no Recanto das } \\
\text { Emas com a forte ventania. }\end{array}$} \\
\hline \multicolumn{4}{|c|}{$\begin{array}{l}\text { Desastre(s) Natural(is) associado(s) à reportagem: Alagamento, enxurrada, } \\
\text { vendaval. }\end{array}$} \\
\hline \multicolumn{4}{|c|}{$\begin{array}{l}\text { Região(ões) Administrativa(s) afetada(s): Taguatinga (RA III), Ceilândia (RA IX), } \\
\text { Samambaia (RA XII) e Recanto das Emas (RA XV). }\end{array}$} \\
\hline
\end{tabular}

\section{Fevereiro}

\begin{tabular}{|c|c|c|c|}
\hline \multicolumn{3}{|c|}{ Notícia no 5 } \\
\hline Dia: 11 & Página: 6 & Caderno: Cidades & Possui Fotos: Sim \\
\hline \multicolumn{3}{|c|}{ Título: A chuva, a erosão e a morte } \\
\hline $\begin{array}{l}\text { Informações adicionais: Três homens caem em vala e são levados pela enxurrada } \\
\text { em forte chuva que caiu na QR 416, na Santa Maria. Um deles, José Ari de Almeida, } \\
\text { de } 49 \text { anos, morreu afogado após passar } 10 \text { minutos na água. Moradores penduram } \\
\text { cordas nos postes para enfrentar as fortes enxurradas quando chove na área. }\end{array}$ \\
\hline Desastre(s) Natural(is) associado(s) à reportagem: Erosão, enxurrada. \\
\hline
\end{tabular}


Região(ões) Administrativa(s) afetada(s): Santa Maria (RA XIII).

Referência bibliográfica: MONTEIRO, Luciana. A chuva, a erosão e a morte. Correio Braziliense, Brasília, 11 de fev. de 2000. Cidades, p. 6.

Março

\begin{tabular}{|c|c|c|c|}
\hline \multicolumn{4}{|c|}{ Notícia n 6} \\
\hline Dia: 04 & Página: - & Caderno: Últimas & Possui Fotos: Sim \\
\hline \multicolumn{4}{|c|}{ Título: Temporal alaga as ruas de Brasília } \\
\hline \multicolumn{4}{|c|}{$\begin{array}{l}\text { Informações adicionais: Entre } 17 \mathrm{~h} 30 \text { e } 20 \mathrm{~h} 30 \text { do dia } 3 \text {, uma chuva de } 33,5 \mathrm{~mm} \text {, de } \\
\text { acordo com o INMET, caiu sobre o Distrito Federal e alagou ruas e tesourinhas do } \\
\text { Plano Piloto. Vários carros enguiçaram com os alagamentos, principalmente na } \\
\text { tesourinha da } 204 \text { e na L2 Norte na altura da quadra } 402 \text {. }\end{array}$} \\
\hline \multicolumn{4}{|c|}{ Desastre(s) Natural(is) associado(s) à reportagem: Alagamento. } \\
\hline \multicolumn{4}{|c|}{ Região(ões) Administrativa(s) afetada(s): Brasília (RA I). } \\
\hline
\end{tabular}

Abril

\begin{tabular}{|c|c|c|c|}
\hline \multicolumn{4}{|c|}{ Notícia nํ 7} \\
\hline Dia: 13 & Página: 2 & Caderno: Cidades & Possui Fotos: Sim \\
\hline \multicolumn{4}{|c|}{ Título: Esgoto dentro de casa } \\
\hline \multicolumn{4}{|c|}{$\begin{array}{l}\text { Informações adicionais: Moradores da QNN } 6 \text { e QNP 12, } 22 \text { e } 26 \text { reclamam que com } \\
\text { as chuvas, o esgoto das ruas alaga as casas. O medo de contrair doenças e o mal } \\
\text { cheiro são constantes no lugar. }\end{array}$} \\
\hline \multicolumn{4}{|c|}{ Desastre(s) Natural(is) associado(s) à reportagem: Alagamento. } \\
\hline \multicolumn{4}{|c|}{ Região(ões) Administrativa(s) afetada(s): Ceilândia (RA IX). } \\
\hline \multicolumn{4}{|c|}{$\begin{array}{l}\text { Referência bibliográfica: REDAÇÃO. Esgoto dentro de casa. Correio Braziliense, } \\
\text { Brasília, } 13 \text { de abr. de } 2000 \text {. Cidades, p. } 2 \text {. }\end{array}$} \\
\hline
\end{tabular}

Agosto 


\begin{tabular}{c|c|c|c|} 
Dia: 10 & Página: 16 & Caderno: Cidades & Possui Fotos: Sim \\
\hline
\end{tabular}

Título: Chuva fora de época alegra e transtorna

Informações adicionais: De acordo com o INMET, de $1 \mathrm{~h}$ da madrugada até $17 \mathrm{~h}$ da tarde do dia 9, choveu 52,4 mm no DF, cerca de quatro vezes mais do que normalmente chove em todo o mês de agosto. Não chovia a cerca de 129 dias. 0 asfalto molhado provocou muitos acidentes de trânsito no Plano Piloto.

Desastre(s) Natural(is) associado(s) à reportagem: Alagamento.

Região(ões) Administrativa(s) afetada(s): Brasília (RA I), Recanto das Emas (RA $\mathrm{XV})$.

Referência bibliográfica: ROCHA, Marcelo. Chuva fora de época alegra e transtorna. Correio Braziliense, Brasília, 10 de ago. de 2000. Cidades, p. 16.

\section{Outubro}

\begin{tabular}{|c|c|c|c|}
\hline \multicolumn{4}{|c|}{ Notícia n 9} \\
\hline Dia: 07 & Página: 3 & Caderno: Últimas & Possui Fotos: Sim \\
\hline \multicolumn{4}{|c|}{ Título: Chuva causa acidente fatal } \\
\hline \multicolumn{4}{|c|}{$\begin{array}{l}\text { Informações adicionais: Chuva causa acidentes de trânsito fatais e alaga casas no } \\
\text { Setor Tradicional, em Planaltina. A água atingiu a altura de cerca de } 1 \text { metro em } \\
\text { algumas casas. }\end{array}$} \\
\hline \multicolumn{4}{|c|}{ Desastre(s) Natural(is) associado(s) à reportagem: Alagamento. } \\
\hline \multicolumn{4}{|c|}{ Região(ões) Administrativa(s) afetada(s): Planaltina (RA VI). } \\
\hline \multicolumn{4}{|c|}{$\begin{array}{l}\text { Referência bibliográfica: REDAÇÃO. Chuva causa acidente fatal. Correio } \\
\text { Braziliense, Brasília, } 07 \text { de out. de } 2006 \text {. Últimas, p. } 3 \text {. }\end{array}$} \\
\hline
\end{tabular}

\begin{tabular}{|c|c|c|c|}
\hline \multicolumn{3}{|c|}{ Notícia no 10 } \\
\hline Dia: 29 & Página: 20 & Caderno: Cidades & Possui Fotos: Não \\
\hline Título: Transtornos com a chuva \\
\hline
\end{tabular}


interrupção dos serviços também na Feira dos Importados e na Rodoferroviária.

Desastre(s) Natural(is) associado(s) à reportagem: Alagamento.

Região(ões) Administrativa(s) afetada(s): Brasília (RA I), Cruzeiro (RA XI), Sudoeste / Octogonal (RA XXII).

Referência bibliográfica: REDAÇÃO. Transtornos com a chuva. Correio Braziliense, Brasília, 29 de out. de 2000. Cidades, p. 20.

\begin{tabular}{|c|c|c|c|}
\hline \multicolumn{4}{|c|}{ Notícia nำ 11} \\
\hline Dia: 31 & Página: 11 & Caderno: Cidades & Possui Fotos: Sim \\
\hline \multicolumn{4}{|c|}{ Título: Chuvas vão continuar } \\
\hline \multicolumn{4}{|c|}{$\begin{array}{l}\text { Informações adicionais: Enxurrada do dia } 30 \text { carrega e mata rapaz na Samambaia } \\
\text { Na Vila Naval, na região de Santa Maria, vendaval destelhou e chuva alagou várias } \\
\text { casas. Pais de alunos, servidores e professores formaram um mutirão na Escola } \\
\text { Classe } 5 \text { do Cruzeiro Novo para que } 400 \text { crianças não ficassem sem aulas devido à } \\
\text { forte enxurrada que alagou a escola. }\end{array}$} \\
\hline \multicolumn{4}{|c|}{$\begin{array}{l}\text { Desastre(s) Natural(is) associado(s) à reportagem: Alagamento, enxurrada e } \\
\text { vendaval. }\end{array}$} \\
\hline \multicolumn{4}{|c|}{$\begin{array}{l}\text { Região(ões) Administrativa(s) afetada(s): Cruzeiro (RA XI), Samambaia (RA II) e } \\
\text { Santa Maria (RA III). }\end{array}$} \\
\hline \multicolumn{4}{|c|}{$\begin{array}{l}\text { Referência bibliográfica: REDAÇÃO. Chuvas vão continuar. Correio Braziliense, } \\
\text { Brasília, } 31 \text { de out. de 2000. Cidades, p. } 11 .\end{array}$} \\
\hline
\end{tabular}

\section{Novembro}

\begin{tabular}{|c|c|c|c|}
\hline \multicolumn{4}{|c|}{ Notícia nำ 12} \\
\hline Dia: 07 & Página: 20 & Caderno: Cidades & Possui Fotos: Sim \\
\hline \multicolumn{4}{|c|}{ Título: Chuvas abrem cratera } \\
\hline \multicolumn{4}{|c|}{$\begin{array}{l}\text { Informações adicionais: Sistema de captação de águas pluviais teve falha e erosão } \\
\text { provocada pela chuvas engoliu dois carros no Setor de Oficinas do Guará II. Defesa } \\
\text { Civil interditou o local. No Recanto das Emas, dois buracos para onde desce a } \\
\text { enxurrada das chuvas servem de depósito de entulho e animais mortos. De acordo } \\
\text { com o Corpo de Bombeiros, entre outubro e novembro houve } 14 \text { casos de alagamento } \\
\text { em residência e comércios, } 60 \text { casas ameaçadas por quedas de árvore e mais de } 600 \\
\text { acidentes de trânsito. O INMET informa na reportagem que nos seis primeiros dias de } \\
\text { novembro choveu } 81 \mathrm{~mm} \text {. }\end{array}$} \\
\hline
\end{tabular}


Desastre(s) Natural(is) associado(s) à reportagem: Erosão.

Região(ões) Administrativa(s) afetada(s): Guará (RA X), Recanto das Emas (RA $\mathrm{XV})$.

Referência bibliográfica: REDAÇÃO. Chuvas abrem cratera. Correio Braziliense, Brasília, 07 de nov. de 2000. Cidades, p. 20.

\begin{tabular}{|c|c|c|c|}
\hline \multicolumn{4}{|c|}{ Notícia nำ 13} \\
\hline Dia: 13 & Página: 12 & Caderno: Cidades & Possui Fotos: Sim \\
\hline \multicolumn{4}{|c|}{ Título: Vinte minutos de chuva e ventos fortes } \\
\hline \multicolumn{4}{|c|}{$\begin{array}{l}\text { Informações adicionais: Às 13h de ontem, uma chuva com ventos muito fortes } \\
\text { atingiu o Setor de Indústria e Abastecimento (SIA), a Octogonal e o Cruzeiro. } \\
\text { Fregueses e feirantes ficaram assustados com o volume de água que caiu na Feira } \\
\text { dos Importados. Vento descobriu algumas barracas. }\end{array}$} \\
\hline \multicolumn{4}{|c|}{ Desastre(s) Natural(is) associado(s) à reportagem: Vendaval. } \\
\hline \multicolumn{4}{|c|}{$\begin{array}{l}\text { Região(ões) Administrativa(s) afetada(s): Cruzeiro (RA X), Sudoeste / Octogonal } \\
\text { (RA XXII) e Setor de Indústria e Abastecimento (RA XXIX). }\end{array}$} \\
\hline \multicolumn{4}{|c|}{$\begin{array}{l}\text { Referência bibliográfica: REDAÇÃO. Vinte minutos de chuva e ventos fortes. Correio } \\
\text { Braziliense, Brasília, } 12 \text { de nov. de } 2000 \text {. Cidades, p. } 13 \text {. }\end{array}$} \\
\hline
\end{tabular}

\section{Dezembro}

\begin{tabular}{|c|c|c|c|}
\hline \multicolumn{4}{|c|}{ Notícia nํ 14} \\
\hline Dia: 15 & Página: 3 & Caderno: Guia & Possui Fotos: Sim \\
\hline \multicolumn{4}{|c|}{ Título: Chuva e erosão ameaçam Conjunto Residencial 45} \\
\hline \multicolumn{4}{|c|}{$\begin{array}{l}\text { Informações adicionais: Na comunidade do Vale do Amanhecer, a seis quilômetros } \\
\text { de Planaltina e às margens da estrada pra Unaí, moradores do Conjunto Residencial } \\
45 \text { estão assustados com erosão na margem do rio Pipiripau. Com a enxurrada das } \\
\text { chuvas e a falta de vegetação da margem dos rios, a cratera está crescendo e levando } \\
\text { fundo de lotes. }\end{array}$} \\
\hline \multicolumn{4}{|c|}{ Desastre(s) Natural(is) associado(s) à reportagem: Enxurrada, erosão. } \\
\hline \multicolumn{4}{|c|}{ Região(ões) Administrativa(s) afetada(s): Planaltina (RA VI). } \\
\hline $\begin{array}{l}\text { Referênci } \\
\text { Residenci }\end{array}$ & $\begin{array}{l}\text { liográfica: } \\
\text { Correio } \mathrm{Brc}\end{array}$ & $\begin{array}{l}\text { Naiobe. Chuva } \\
\text { Brasília, } 15 \text { de d }\end{array}$ & $\begin{array}{l}\text { meaçam Conjunto } \\
\text {. Guia, p. } 3 .\end{array}$ \\
\hline
\end{tabular}




\section{APÊNDICE II}

Desastres Naturais relacionados às chuvas no Distrito Federal relatados no jornal Correio Braziliense no ano de 2001

Janeiro

\begin{tabular}{|c|c|c|c|}
\hline \multicolumn{4}{|c|}{ Notícia no 1} \\
\hline Dia: 21 & Página: 19 & Caderno: Cidades & Possui Fotos: Sim \\
\hline \multicolumn{4}{|c|}{ Título: Chuva alaga Setor de Oficinas } \\
\hline \multicolumn{4}{|c|}{$\begin{array}{l}\text { Informações adicionais: Chuva forte alagou o Setor de Oficinas Sul, no Guará. } \\
\text { Carros foram arrastados e passageiros tiveram que se apoiar nos bancos e tetos de } \\
\text { ônibus para não serem atingidos pelas águas. Em alguns pontos, água alagou cerca } \\
\text { de um metro de profundidade. }\end{array}$} \\
\hline \multicolumn{4}{|c|}{ Desastre(s) Natural(is) associado à reportagem: Alagamento. } \\
\hline \multicolumn{4}{|c|}{ Região(ões) Administrativa(s) afetada(s): Guará (RA X) } \\
\hline \multicolumn{4}{|c|}{$\begin{array}{l}\text { Referência bibliográfica: REDAÇÃO. Chuva alaga Setor de Oficinas. Correio } \\
\text { Braziliense, Brasília, } 19 \text { de jan. de 2001. Cidades, p. } 19 .\end{array}$} \\
\hline
\end{tabular}

\begin{tabular}{|l|c|c|}
\hline \multicolumn{3}{|c|}{ Notícia no 2} \\
\hline Dia: 25 & \multicolumn{1}{|c|}{ Página: 3} & \multicolumn{1}{c|}{ Caderno: Guia } \\
\hline Título: Erosão destrói ruas e põe moradores em risco \\
\hline $\begin{array}{l}\text { Informações adicionais: Quando chove, enxurrada leva cascalho que a } \\
\text { Administração de Santa Maria põe para tapar erosão que fica no meio da rua no } \\
\text { Conjunto "A" da quadra 402. Sem infraestrutura de coleta de águas pluviais, } \\
\text { moradores ficam preocupados, pois afirmam que força da água é capaz de arrastar } \\
\text { pessoas. }\end{array}$ \\
\hline Desastre(s) Natural(is) associado(s) à reportagem: Enxurrada, erosão. \\
\hline Região(ões) Administrativa(s) afetada(s): Santa Maria (RA XIII). \\
\hline $\begin{array}{l}\text { Referência bibliográfica: CASTRO, André Augusto. Erosão destrói ruas e põe } \\
\text { moradores em risco. Correio Braziliense, Brasília, 25 de jan. de 2001. Guia, p. 3. }\end{array}$ \\
\hline
\end{tabular}


Março

\begin{tabular}{|c|c|c|c|}
\hline \multicolumn{4}{|c|}{ Notícia n 3} \\
\hline Dia: 06 & Página: 3 & Caderno: Últimas & Possui Fotos: Sim \\
\hline \multicolumn{4}{|c|}{ Título: Temporal adia voos e tumultua trânsito } \\
\hline \multicolumn{4}{|c|}{$\begin{array}{l}\text { Informações adicionais: Chuva foi tão forte e concentrada que o aeroporto precisou } \\
\text { ser fechado por } 12 \text { minutos para pousos e decolagens. Vento forte derrubou árvores e } \\
\text { fechou o trânsito na W3 Norte. Outras árvores caíram na } 104 \text { e } 304 \text { Norte, atingidas } \\
\text { por raios. Na Rodoviária do Plano Piloto e Esplanada dos Ministérios, as pistas ficaram } \\
\text { alagadas. }\end{array}$} \\
\hline \multicolumn{4}{|c|}{ Desastre(s) Natural(is) associado(s) à reportagem: Alagamento, vendaval. } \\
\hline \multicolumn{4}{|c|}{ Região(ões) Administrativa(s) afetada(s): Brasília (RA I). } \\
\hline \multicolumn{4}{|c|}{$\begin{array}{l}\text { Referência bibliográfica: CHARLSON, Freddy. Temporal adia voos e tumultua } \\
\text { trânsito. Correio Braziliense, Brasília, } 6 \text { de mar. de 2001. Últimas, p. } 3 .\end{array}$} \\
\hline
\end{tabular}

\begin{tabular}{|c|c|c|c|}
\hline \multicolumn{4}{|c|}{ Notícia n 4} \\
\hline Dia: 15 & Página: 30 & Caderno: Cidades & Possui Fotos: Sim \\
\hline \multicolumn{4}{|c|}{ Título: Estado de emergência } \\
\hline \multicolumn{4}{|c|}{$\begin{array}{l}\text { Informações adicionais: Criação da Região Administrativa de Santa Maria reduziu o } \\
\text { volume de um ribeirão por causa de lixo e de erosões. O problema afeta o } \\
\text { abastecimento de água na cidade de Novo Gama, no Goiás, que é abastecida pelo } \\
\text { ribeirão. Retirada de areia às margens do ribeirão Santa Maria somada às chuvas } \\
\text { entope o sistema de distribuição de água na cidade vizinha. }\end{array}$} \\
\hline \multicolumn{4}{|c|}{ Desastre(s) Natural(is) associado(s) à reportagem: Erosão. } \\
\hline \multicolumn{4}{|c|}{ Região(ões) Administrativa(s) afetada(s): Santa Maria (RA XIII). } \\
\hline \multicolumn{4}{|c|}{$\begin{array}{l}\text { Referência bibliográfica: REDAÇÃO. Estado de emergência. Correio Braziliense, } \\
\text { Brasília, } 15 \text { de mar. de } 2001 \text {. Cidades, p. } 20 .\end{array}$} \\
\hline
\end{tabular}

\section{Maio}

\begin{tabular}{|c|c|c|c|}
\hline \multicolumn{3}{|c|}{ Notícia no 5 } \\
\hline Dia: 2 & Página: 3 & Caderno: Guia & Possui Fotos: Sim \\
\hline \multicolumn{2}{|l|}{ Título: Chuva inunda prédio por causa de obras } \\
\hline
\end{tabular}


Informações adicionais: Construção de estacionamento de prédio no Bloco D da quadra 407 do Cruzeiro Novo pela administração da cidade provoca transtornos aos moradores. Chuva alaga o andar térreo devido à falta de infraestrutura, pois a água não tem para onde escorrer.

Desastre(s) Natural(is) associado(s) à reportagem: Alagamento.

Região(ões) Administrativa(s) afetada(s): Cruzeiro (RA XI).

Referência bibliográfica: CASTRO, André Augusto. Chuva inunda prédio por causa de obras. Correio Braziliense, Brasília, 2 de mai. de 2001. Guia, p. 6.

Agosto

\begin{tabular}{|c|c|c|c|}
\hline \multicolumn{4}{|c|}{ Notícia n 6} \\
\hline Dia: 31 & Página: 19 & Caderno: Cidades & Possui Fotos: Sim \\
\hline \multicolumn{4}{|c|}{ Título: Águas começam a rolar } \\
\hline \multicolumn{4}{|c|}{$\begin{array}{l}\text { Informações adicionais: O Centro de Operações da Polícia Militar (COPOM) } \\
\text { registrou mais de } 20 \text { acidentes de trânsito em decorrência das pistas escorregadias } \\
\text { com a água da chuva. Estiagem é a mais curta dos últimos } 11 \text { anos, de acordo com o } \\
\text { INMET. Várias ruas do Plano Piloto ficaram alagadas. }\end{array}$} \\
\hline \multicolumn{4}{|c|}{ Desastre(s) Natural(is) associado(s) à reportagem: Alagamento. } \\
\hline \multicolumn{4}{|c|}{ Região(ões) Administrativa(s) afetada(s): Brasília (RA I). } \\
\hline
\end{tabular}




\section{APÊNDICE III}

Desastres Naturais relacionados às chuvas no Distrito Federal relatados no jornal Correio Braziliense no ano de 2002

Janeiro

\begin{tabular}{|c|c|c|c|}
\hline \multicolumn{4}{|c|}{ Notícia $n \div 1$} \\
\hline Dia: 06 & Página: 12 & Caderno: Cidades & Possui Fotos: Sim \\
\hline \multicolumn{4}{|c|}{ Título: Cidades alagadas no Distrito Federal } \\
\hline \multicolumn{4}{|c|}{$\begin{array}{l}\text { Informações adicionais: Com as chuvas constantes que atingem o Distrito Federal, } \\
\text { Goiás e Minas Gerais, os moradores convivem com a lama invadindo as casas, roupas } \\
\text { ensopadas, falhas no asfalto e doenças. Os transtornos trazidos pelas chuvas expõem } \\
\text { os problemas da infraestrutura deficiente. Na quadra } 307 \text { do Recanto das Emas, } \\
\text { Simone Vieira Batista reclama da lama e do lixo que são carregados para a porta de } \\
\text { casa com a enxurrada. No conjunto } 3 \text { da QR } 604 \text { da Samambaia, pontos de ônibus } \\
\text { distantes e sem abrigo encharcam quem precisa utilizar o transporte público. }\end{array}$} \\
\hline \multicolumn{4}{|c|}{ Desastre(s) Natural(is) associado à reportagem: Alagamento, enxurrada. } \\
\hline \multicolumn{4}{|c|}{$\begin{array}{l}\text { Região(ões) Administrativa(s) afetada(s): Samambaia (RA XII), Santa Maria (RA } \\
\text { XIII), São Sebastião (RA XIV), Riacho Fundo II (RA XXI), Recanto das Emas (RA XV). }\end{array}$} \\
\hline \multicolumn{4}{|c|}{$\begin{array}{l}\text { Referência bibliográfica: REDAÇÃO. Cidades alagadas no Distrito Federal. Correio } \\
\text { Braziliense, Brasília, } 06 \text { de jan. de } 2002 \text {. Cidades, p. } 12 \text {. }\end{array}$} \\
\hline
\end{tabular}

Fevereiro

\begin{tabular}{|c|c|c|c|}
\hline \multicolumn{4}{|c|}{ Notícia $n \div 2$} \\
\hline Dia: 19 & Página: 14 & Caderno: Cidades & Possui Fotos: Sim \\
\hline \multicolumn{4}{|c|}{ Título: Tempo fecha em Brasília } \\
\hline \multicolumn{4}{|c|}{$\begin{array}{l}\text { Informações adicionais: Aguaceiro de } 30 \text { minutos passou rápido, mas foi o suficiente } \\
\text { para deixar vários pontos de Brasília alagados. De acordo com o INMET, nesse curto } \\
\text { período de tempo, foram } 27 \mathrm{~mm} \text { de volume de água da chuva. Raios causaram pane } \\
\text { que deixou semáforos desligados nas vias } \mathrm{L} 2 \text {, W3 e Eixo Monumental, afetando } \\
\text { também Taguatinga. A central de atendimento do Corpo de Bombeiros também foi } \\
\text { afetada por raios e ficou indisponível na hora do temporal. Carros ficaram alegados no } \\
\text { Setor de Oficinas Sul, no Guará. }\end{array}$} \\
\hline \multicolumn{4}{|c|}{ Desastre(s) Natural(is) associado(s) à reportagem: Alagamento. } \\
\hline \multicolumn{4}{|c|}{ Região(ões) Administrativa(s) afetada(s): Guará (RA X). } \\
\hline
\end{tabular}


Referência bibliográfica: REDAÇÃO. Tempo fecha em Brasília. Correio Braziliense, Brasília, 19 de fev. de 2002. Cidades, p. 14.

Agosto

\begin{tabular}{|c|c|c|c|}
\hline \multicolumn{4}{|c|}{ Notícia nㅇ 3} \\
\hline Dia: 28 & Página: 35 & Caderno: Cidades & Possui Fotos: Sim \\
\hline \multicolumn{4}{|c|}{ Título: Granizo na tarde seca } \\
\hline \multicolumn{4}{|c|}{$\begin{array}{l}\text { Informações adicionais: Pedrinhas de gelo do tamanho de bolas de gude caíram } \\
\text { sobre várias cidades do Distrito Federal por volta das } 15 \mathrm{~h} \text {, provocando alguns } \\
\text { transtornos, sobretudo no trânsito. Fenômeno é típico das primeiras chuvas ocorridas } \\
\text { após o fim da estação seca, devido ao calor presente no ar. O INMET registrou } 12 \mathrm{~mm} \\
\text { de precipitação. }\end{array}$} \\
\hline \multicolumn{4}{|c|}{ Desastre(s) Natural(is) associado(s) à reportagem: Granizo. } \\
\hline \multicolumn{4}{|c|}{$\begin{array}{l}\text { Região(ões) Administrativa(s) afetada(s): Brasília (RA I), Brazlândia (RA IV), } \\
\text { Ceilândia (RA XI), Riacho Fundo (RA XVII), Samambaia (RA XII) e Taguatinga (RA III). }\end{array}$} \\
\hline \multicolumn{4}{|c|}{$\begin{array}{l}\text { Referência bibliográfica: HILÁRIO, Rodrigo; FARIA, Tiago. Granizo na tarde seca. } \\
\text { Correio Braziliense, Brasília, } 19 \text { de ago. de } 2000 \text {. Cidades, p. } 35 .\end{array}$} \\
\hline
\end{tabular}

\section{Setembro}

\begin{tabular}{|c|c|c|c|}
\hline \multicolumn{4}{|c|}{ Notícia no 4} \\
\hline Dia: 06 & Página: 3 & Caderno: Cidades & Possui Fotos: Sim \\
\hline \multicolumn{4}{|c|}{ Título: Tarde de chuva faz estragos na cidade } \\
\hline \multicolumn{4}{|c|}{$\begin{array}{l}\text { Informações adicionais: Chuva com muitas descargas elétricas e ventos de até } 80 \\
\mathrm{~km} / \mathrm{h} \text { derrubou a energia elétrica, alagou vários pontos, fechou o aeroporto, destelhou } \\
\text { casas e provocou queda de árvores em muitas localidades do DF. Por maior que } \\
\text { tenham sidos os transtornos, chuva registrada pelo INMET foi de } 5 \mathrm{~mm} \text {. Ceilândia, } \\
\text { Riacho Fundo I e II e Taguatinga foram as Regiões Administrativas mais afetadas com } \\
\text { temporal. }\end{array}$} \\
\hline \multicolumn{4}{|c|}{ Desastre(s) Natural(is) associado(s) à reportagem: Alagamento, vendaval. } \\
\hline \multicolumn{4}{|c|}{$\begin{array}{l}\text { Região(ões) Administrativa(s) afetada(s): Ceilândia (RA XI), Riacho Fundo (RA } \\
\text { XVII) e Taguatinga (RA III). }\end{array}$} \\
\hline \multicolumn{4}{|c|}{$\begin{array}{l}\text { Referência bibliográfica: XAVIER, Marcello. Tarde de chuva faz estragos na cidade. } \\
\text { Correio Braziliense, Brasília, } 06 \text { de set. de } 2002 \text {. Cidades, p. } 3 .\end{array}$} \\
\hline
\end{tabular}




\section{Dezembro}

\begin{tabular}{|c|c|c|c|}
\hline \multicolumn{4}{|c|}{ Notícia $n \div 5$} \\
\hline Dia: 27 & Página: 13 & Caderno: Cidades & Possui Fotos: Sim \\
\hline \multicolumn{4}{|c|}{ Título: Chuva destrói lojas no Guará } \\
\hline \multicolumn{4}{|c|}{$\begin{array}{l}\text { Informações adicionais: Água da chuva alagou várias lojas na Área Especial } 4 \text { do } \\
\text { Guará II. Volume atingiu cerca de } 80 \mathrm{~cm} \text { de altura e enxurrada derrubou muros e } \\
\text { paredes, enchendo de lama todo o local. }\end{array}$} \\
\hline \multicolumn{4}{|c|}{ Desastre(s) Natural(is) associado(s) à reportagem: Alagamento, enxurrada. } \\
\hline \multicolumn{4}{|c|}{ Região(ões) Administrativa(s) afetada(s): Guará (RA X). } \\
\hline \multicolumn{4}{|c|}{$\begin{array}{l}\text { Referência bibliográfica: FERRI, Maria. Chuva destrói lojas no Guará. Correio } \\
\text { Braziliense, Brasília, } 27 \text { de dez. de } 2002 \text {. Cidades, p. } 13 \text {. }\end{array}$} \\
\hline
\end{tabular}

\begin{tabular}{|c|c|c|c|}
\hline \multicolumn{4}{|c|}{ Notícia nะ 6} \\
\hline Dia: 31 & Página: 14 & Caderno: Cidades & Possui Fotos: Sim \\
\hline \multicolumn{4}{|c|}{ Título: Dia de contabilizar prejuízos } \\
\hline \multicolumn{4}{|c|}{$\begin{array}{l}\text { Informações adicionais: Os } 94,8 \text { mm de precipitação contabilizados pelo INMET no } \\
\text { dia } 29 \text { causaram muitos estragos no DF. Foi a chuva mais forte do ano. O acesso da } \\
\text { via L4 para a Ponte JK ficou alagado. Alguns carros ficaram boiando na água. Água } \\
\text { também a alagou várias lojas na Asa Sul e Norte. Feira dos Importados, no Setor de } \\
\text { Indústria e Abastecimento, também contabilizou prejuízos, pois água atingiu mais de } \\
50 \mathrm{~cm} \text { de altura. }\end{array}$} \\
\hline \multicolumn{4}{|c|}{ Desastre(s) Natural(is) associado(s) à reportagem: Alagamento. } \\
\hline \multicolumn{4}{|c|}{$\begin{array}{l}\text { Região(ões) Administrativa(s) afetada(s): Brasília (RA I), Setor de Indústria e } \\
\text { Abastecimento (RA XXIX). }\end{array}$} \\
\hline \multicolumn{4}{|c|}{$\begin{array}{l}\text { Referência bibliográfica: FERRI, Maria. Dia de contabilizar prejuízos. Correio } \\
\text { Braziliense, Brasília, } 31 \text { de dez. de 2002. Cidades, p. } 14 \text {. }\end{array}$} \\
\hline
\end{tabular}




\section{APÊNDICE IV}

\section{Desastres Naturais relacionados às chuvas no Distrito Federal relatados no jornal Correio Braziliense no ano de 2003}

Janeiro

\begin{tabular}{|c|c|c|c|}
\hline \multicolumn{4}{|c|}{ Notícia no 1} \\
\hline Dia: 12 & Página: 11 & Caderno: Brasil & Possui Fotos: Sim \\
\hline \multicolumn{4}{|c|}{ Título: Estragos também no DF } \\
\hline \multicolumn{4}{|c|}{$\begin{array}{l}\text { Informações adicionais: Na Santa Maria, teto de ginásio recém-inaugurado tombou } \\
\text { pela metade e telhados de casas foram arrancados pela força do vento que veio } \\
\text { acompanhado de chuva. No Recanto das Emas, moradores reclamam do } \\
\text { destelhamento de casas e de fortes enxurradas que estão carregando o asfalto das } \\
\text { ruas. No Jardim Botânico o vento arrancou árvores pelas raízes e o granizo destruiu } \\
\text { viveiros de plantas. Quatro árvores despencaram sobre a estufa. Os danos } \\
\text { ultrapassam } 1 \text { milhão de reais, de acordo com a diretora do Jardim. }\end{array}$} \\
\hline \multicolumn{4}{|c|}{$\begin{array}{l}\text { Desastre(s) Natural(is) associado à reportagem: Alagamento, granizo, enxurrada, } \\
\text { vendaval. }\end{array}$} \\
\hline \multicolumn{4}{|c|}{$\begin{array}{l}\text { Região(ões) Administrativa(s) afetada(s): Santa Maria (RA XIII), Jardim Botânico } \\
\text { (RA XXVII) e Recanto das Emas (RA XV). }\end{array}$} \\
\hline
\end{tabular}

\section{Dezembro}

\begin{tabular}{|c|c|c|c|}
\hline \multicolumn{4}{|c|}{ Notícia no 2} \\
\hline Dia: 23 & Página: 24 & Caderno: Cidades & Possui Fotos: Sim \\
\hline \multicolumn{4}{|c|}{ Título: Ventos derrubam árvores } \\
\hline \multicolumn{4}{|c|}{$\begin{array}{l}\text { Informações adicionais: Vento fez árvores despencarem sobre escola na } 103 \text { Sul e } \\
\text { sobre carros na } 407 \text { Sul, impedindo a passagem de outros veículos. }\end{array}$} \\
\hline \multicolumn{4}{|c|}{ Desastre(s) Natural(is) associado(s) à reportagem: Vendaval. } \\
\hline \multicolumn{4}{|c|}{ Região(ões) Administrativa(s) afetada(s): Guará (RA X). } \\
\hline
\end{tabular}




\section{APÊNDICE V}

\section{Desastres Naturais relacionados às chuvas no Distrito Federal relatados no jornal Correio Braziliense no ano de 2004}

\section{Fevereiro}

\begin{tabular}{|c|c|c|c|}
\hline \multicolumn{4}{|c|}{ Notícia nํ 1} \\
\hline Dia: 04 & Página: 26 & Caderno: Cidades & Possui Fotos: Sim \\
\hline \multicolumn{4}{|c|}{ Título: Chuvas de fevereiro começam mais fortes } \\
\hline \multicolumn{4}{|c|}{$\begin{array}{l}\text { Informações adicionais: Em três dias choveu o correspondente a } 25 \% \text { do previsto } \\
\text { para o mês ( } 53 \mathrm{~mm} \text {, de acordo com o INMET). Chuva alagou e vento destelhou casas } \\
\text { e deixou } 30 \text { famílias desabrigadas no Varjão. Regularidade das chuvas também tem } \\
\text { aumentado os buracos nas vias do Distrito Federal, principalmente no Plano Piloto, e } \\
\text { causado muitos engarrafamentos por conta de acidentes de trânsito. }\end{array}$} \\
\hline \multicolumn{4}{|c|}{ Desastre(s) Natural(is) associado à reportagem: Alagamento, enxurrada, vendaval. } \\
\hline \multicolumn{4}{|c|}{ Região(ões) Administrativa(s) afetada(s): Itapoã (RA XXVIII). } \\
\hline $\begin{array}{l}\text { Referênc } \\
\text { Correio } B\end{array}$ & $\begin{array}{l}\text { liográfica: } \mathrm{F} \\
\text { nse, Brasília }\end{array}$ & $\begin{array}{l}\text {, Maria. Chuvas de fe } \\
\text { e fev. de } 2004 \text {. Cidad }\end{array}$ & omeçam mais fortes. \\
\hline
\end{tabular}

\begin{tabular}{|c|c|c|c|}
\hline \multicolumn{4}{|c|}{ Notícia $n=2$} \\
\hline Dia: 08 & Página: 27 & Caderno: Cidades & Possui Fotos: Sim \\
\hline \multicolumn{4}{|c|}{ Título: A maior chuva do ano } \\
\hline \multicolumn{4}{|c|}{$\begin{array}{l}\text { Informações adicionais: Aguaceiro de } 41,2 \mathrm{~mm} \text {, de acordo com o INMET, foi } \\
\text { responsável por vários transtornos na capital. Na Asa Sul, garagem de clínica ficou } \\
\text { com água até o teto e árvore foi derrubada na } 106 \text { Sul pela forte ventania. No Gama, } \\
\text { queda de barranco fechou a DF-290. No Varjão, três barrancos caíram e dois } \\
\text { ameaçam cair se a chuva continuar. }\end{array}$} \\
\hline \multicolumn{4}{|c|}{$\begin{array}{l}\text { Desastre(s) Natural(is) associado(s) à reportagem: Alagamento, movimentos de } \\
\text { massa, vendaval. }\end{array}$} \\
\hline \multicolumn{4}{|c|}{$\begin{array}{l}\text { Região(ões) Administrativa(s) afetada(s): Brasília (RA I), Gama (RA II), Varjão (RA } \\
\text { XXIII). }\end{array}$} \\
\hline \multicolumn{4}{|c|}{$\begin{array}{l}\text { Referência bibliográfica: REDAÇÃO. A maior chuva do ano. Correio Braziliense, } \\
\text { Brasília, } 8 \text { de fev. de 2004. Cidades, p. } 27 .\end{array}$} \\
\hline
\end{tabular}




\begin{tabular}{c|c|c|c|} 
Dia: 10 & Página: 24 & Caderno: Cidades & Possui Fotos: Sim \\
\hline
\end{tabular}

Título: Temporada recorde de chuva, lama e buraco

Informações adicionais: Na L2 Norte, as quadras 112/114 Norte, em reforma, tem passado por diversos alagamentos. A Defesa Civil registrou 193 ocorrências por risco de desabamento em várias localidades. Em Vicente Pires, a rua 10 vive alagada constantemente. Barragem do Paranoá foi aberta para dar vazão ao excedente do volume de água.

Desastre(s) Natural(is) associado(s) à reportagem: Alagamento.

Região(ões) Administrativa(s) afetada(s): Brasília (RA I), Vicente Pires (RA XXX)

Referência bibliográfica: REDAÇÃO. Temporada recorde de chuva, lama e buraco. Correio Braziliense, Brasília, 8 de fev. de 2004. Cidades, p. 24.

\begin{tabular}{|c|c|c|c|}
\hline \multicolumn{4}{|c|}{ Notícia no 4} \\
\hline Dia: 11 & Página: 21 & Caderno: Cidades & Possui Fotos: Sim \\
\hline \multicolumn{4}{|c|}{ Título: Chuva e destruição } \\
\hline \multicolumn{4}{|c|}{$\begin{array}{l}\text { Informações adicionais: De acordo com o INMET, nos } 10 \text { primeiros dias de fevereiro } \\
\text { já choveu } 211 \mathrm{~mm} \text {. São mais de } 40 \text { dias contínuos de chuva devido a um bloqueio } \\
\text { atmosférico que está presente na região. Em alguns pontos a velocidade do vento } \\
\text { atingiu } 70 \mathrm{~km} / \mathrm{h} \text {. Vento provocou queda de árvores em Vicente Pires, Águas Claras, } \\
\text { Setor de Indústrias Gráficas (SIG), Guará e Plano Piloto (quadras } 104,116,408 \text { e } \\
907 / 908 \text { Sul e } 715 / 716 \text { Norte). A estação de metrô da Galeria dos Estados ficou } \\
\text { alagada. Em Planaltina e no Lago Sul, enxurradas varreram as ruas e alagaram } \\
\text { algumas casas. O Setor Hoteleiro Sul e o Setor Comercial Sul ficaram sem energia por } \\
\text { algumas horas. Bombeiros registraram } 40 \text { pedidos de socorro. }\end{array}$} \\
\hline \multicolumn{4}{|c|}{$\begin{array}{l}\text { Desastre(s) Natural(is) associado(s) à reportagem: Alagamento, enxurrada, } \\
\text { vendaval. }\end{array}$} \\
\hline \multicolumn{4}{|c|}{$\begin{array}{l}\text { Região(ões) Administrativa(s) afetada(s): Águas Claras (RA XX), Brasília (RA I), } \\
\text { Guará (RA X), Lago Sul (RA XVI), Planaltina (RA VI). }\end{array}$} \\
\hline \multicolumn{4}{|c|}{$\begin{array}{l}\text { Referência bibliográfica: FERRI, Maria. Chuva e destruição. Correio Braziliense, } \\
\text { Brasília, } 11 \text { de fev. de 2004. Cidades, p. } 21 \text {. }\end{array}$} \\
\hline
\end{tabular}




\section{Notícia $\mathrm{n}^{\circ} 5$}

\begin{tabular}{l|l|l|l} 
Dia: 11 & Página: 22 & Caderno: Cidades & Possui Fotos: Sim \\
\hline
\end{tabular}

Título: Inundação e famílias desalojadas

Informações adicionais: Os mais de 40 dias ininterruptos de chuvas obrigaram a Companhia Energética de Brasília (CEB) a abrir as comportas do Lago Paranoá. $\mathrm{Na}$ QI 4 do Lago Sul, casas ficaram alagadas. Número de famílias desabrigadas cresce.

Desastre(s) Natural(is) associado(s) à reportagem: Alagamento.

Região(ões) Administrativa(s) afetada(s): Lago Sul (RA XVI).

Referência bibliográfica: MEIRA, Larissa; GÓIS, Fabíola. Inundação e famílias desalojadas. Correio Braziliense, Brasília, 11 de fev. de 2004. Cidades, p. 22.

\begin{tabular}{|c|c|c|c|}
\hline \multicolumn{4}{|c|}{ Notícia $n \div 6$} \\
\hline Dia: 19 & Página: 37 & Caderno: Cidades & Possui Fotos: Sim \\
\hline \multicolumn{4}{|c|}{ Título: Estragos que não têm fim } \\
\hline \multicolumn{4}{|c|}{$\begin{array}{l}\text { Informações adicionais: No Plano Piloto, tesourinhas ficaram alagadas e um carro foi } \\
\text { atingido por árvore. Até o dia 18, INMET registrou } 299 \mathrm{~mm} \text { de precipitação em todo o } \\
\text { DF. Por precaução, } 15 \text { famílias foram retiradas de suas casas pela Defesa Civil no } \\
\text { Varjão. }\end{array}$} \\
\hline \multicolumn{4}{|c|}{ Desastre(s) Natural(is) associado(s) à reportagem: Alagamento. } \\
\hline \multicolumn{4}{|c|}{ Região(ões) Administrativa(s) afetada(s): Brasília (RA IX). } \\
\hline \multicolumn{4}{|c|}{$\begin{array}{l}\text { Referência bibliográfica: REDAÇÃO. Estragos que não têm fim. Correio Braziliense, } \\
\text { Brasília, } 19 \text { de dez. de } 2004 \text {. Cidades, p. } 37 .\end{array}$} \\
\hline
\end{tabular}

\section{Março}

\begin{tabular}{|c|c|c|c|}
\hline \multicolumn{3}{|c|}{ Notícia no 7} \\
\hline Dia: 18 & Página: 29 & Caderno: Cidades & Possui Fotos: Sim \\
\hline Título: Águas derrubam casas \\
\hline $\begin{array}{l}\text { Informações adicionais: Águas alagaram e derrubaram casas com transbordamento } \\
\text { do córrego Riacho Fundo, na Vila Cauhy, Núcleo Bandeirante. Cerca de } 30 \text { pessoas } \\
\text { ficaram desabrigadas e estão sendo atendidas pela Defesa Civil. }\end{array}$ \\
\hline Desastre(s) Natural(is) associado(s) à reportagem: Alagamento. \\
\hline
\end{tabular}


Região(ões) Administrativa(s) afetada(s): Núcleo Bandeirante (RA VIII).

Referência bibliográfica: FERRI, Maria. Águas derrubam casas. Correio Braziliense, Brasília, 18 de mar. de 2004. Cidades, p. 29.

Abril

\begin{tabular}{|c|c|c|c|}
\hline \multicolumn{4}{|c|}{ Notícia nㅇ 8} \\
\hline Dia: 10 & Página: 24 & Caderno: Cidades & Possui Fotos: Sim \\
\hline \multicolumn{4}{|c|}{ Título: Temporal provoca estragos } \\
\hline \multicolumn{4}{|c|}{$\begin{array}{l}\text { Informações adicionais: No dia 9, sexta-feira da paixão, chuva de } 26,8 \mathrm{~mm} \text { provocou } \\
\text { estragos. Vento chegou a } 70 \mathrm{~km} / \mathrm{h} \text {, de acordo com o INMET. Vento derrubou tapume } \\
\text { das obras do Museu Nacional e entortou semáforos na Esplanada dos Ministérios. } \\
\text { Água alagou tesourinhas e complicou o trânsito na L2 Sul. No Lago Sul, carros foram } \\
\text { carregados pela enxurrada. Parte da Asa Norte ficou sem energia elétrica. }\end{array}$} \\
\hline \multicolumn{4}{|c|}{$\begin{array}{l}\text { Desastre(s) Natural(is) associado(s) à reportagem: Alagamento, enxurrada, } \\
\text { vendaval. }\end{array}$} \\
\hline \multicolumn{4}{|c|}{ Região(ões) Administrativa(s) afetada(s): Brasília (RA I), Lago Sul (RA XVI). } \\
\hline \multicolumn{4}{|c|}{$\begin{array}{l}\text { Referência bibliográfica: REDAÇÃO. Temporal provoca estragos. Correio } \\
\text { Braziliense, Brasília, } 10 \text { de abr. de } 2004 \text {. Cidades, p. } 24 \text {. }\end{array}$} \\
\hline
\end{tabular}

\begin{tabular}{|c|c|c|c|}
\hline \multicolumn{4}{|c|}{ Notícia n 9} \\
\hline Dia: 15 & Página: 35 & Caderno: Cidades & Possui Fotos: Sim \\
\hline \multicolumn{4}{|c|}{ Título: Choveu, inundou } \\
\hline \multicolumn{4}{|c|}{$\begin{array}{l}\text { Informações adicionais: Na Asa Norte, } 10 \text { anos mais nova que a Asa Sul, as } \\
\text { tesourinhas das quadras } 202 / 402,211 / 411,213 / 413,216 / 416 \text { e as lojas das quadras } \\
111,714,715 \text { e } 716 \text { são alvos certos de alagamento durante as chuvas. Capacidade } \\
\text { de coleta da rede de águas pluviais está abaixo da capacidade, de acordo com o } \\
\text { Corpo de Bombeiros. Construções nas quadras } 900 \text { e desnível altimétrico são } \\
\text { apontados como responsáveis por intensificar os alagamentos. }\end{array}$} \\
\hline \multicolumn{4}{|c|}{ Desastre(s) Natural(is) associado(s) à reportagem: Alagamento. } \\
\hline \multicolumn{4}{|c|}{ Região(ões) Administrativa(s) afetada(s): Brasília (RA I). } \\
\hline $\begin{array}{l}\text { Referênci } \\
\text { Brasília, } 1\end{array}$ & $\begin{array}{l}\text { bliográfica: } \\
\text { abr. de } 2004\end{array}$ & $\begin{array}{l}\text { CA, Aline. Choveu, i } \\
\text { es, p. } 35 .\end{array}$ & Correio Braziliense, \\
\hline
\end{tabular}




\begin{tabular}{|c|c|c|c|}
\hline \multicolumn{4}{|c|}{ Notícia $\mathrm{n} \div 10$} \\
\hline Dia: 15 & Página: 35 & Caderno: Cidades & Possui Fotos: Sim \\
\hline \multicolumn{4}{|c|}{ Título: Buracos e lama em terminal } \\
\hline \multicolumn{4}{|c|}{$\begin{array}{l}\text { Informações adicionais: Terminal rodoviário de São Sebastião está repleto de } \\
\text { buracos e muita lama. Local não tem cobertura e não é asfaltado. Passageiros } \\
\text { reclamam do desconforto, que aumenta com as chuvas devido aos constantes } \\
\text { alagamentos no local. }\end{array}$} \\
\hline \multicolumn{4}{|c|}{ Desastre(s) Natural(is) associado(s) à reportagem: Alagamento. } \\
\hline \multicolumn{4}{|c|}{ Região(ões) Administrativa(s) afetada(s): São Sebastião (RA XIV). } \\
\hline \multicolumn{4}{|c|}{$\begin{array}{l}\text { Referência bibliográfica: GOULART, Guilherme. Buracos e lama em terminal. } \\
\text { Correio Braziliense, Brasília, } 15 \text { de abr. de } 2004 \text {. Cidades, p. } 35 .\end{array}$} \\
\hline
\end{tabular}

\section{Dezembro}

\begin{tabular}{|c|c|c|c|}
\hline \multicolumn{4}{|c|}{ Notícia nำ 11} \\
\hline Dia: 16 & Página: 48 & Caderno: Cidades & Possui Fotos: Sim \\
\hline \multicolumn{4}{|c|}{ Título: Chuva alaga a cidade } \\
\hline \multicolumn{4}{|c|}{$\begin{array}{l}\text { Informações adicionais: A chuva que caiu entre } 12 \mathrm{~h} \text { e } 14 \mathrm{~h} \text { alagou diversos pontos do } \\
\text { Distrito Federal. Cerca de } 22 \text { carros ficaram alagados na Cidade do Automóvel. INMET } \\
\text { registrou } 15,4 \mathrm{~mm} \text { nesse período. Ventos atingiram } 32 \mathrm{~km} / \mathrm{h} \text { e prejudicaram a } \\
\text { visibilidade dos motoristas. Enxurrada deixou van ilhada próximo à Feira dos } \\
\text { Importados, no SIA. }\end{array}$} \\
\hline \multicolumn{4}{|c|}{$\begin{array}{l}\text { Desastre(s) Natural(is) associado(s) à reportagem: Alagamento, enxurrada, } \\
\text { vendaval. }\end{array}$} \\
\hline \multicolumn{4}{|c|}{ Região(ões) Administrativa(s) afetada(s): SCIA (RA XXV), SIA (RA XXIX). } \\
\hline \multicolumn{4}{|c|}{$\begin{array}{l}\text { Referência bibliográfica: COSTA, Netto. Chuva alaga a cidade. Correio Braziliense, } \\
\text { Brasília, } 16 \text { de dez. de 2004. Cidades, p. } 48 .\end{array}$} \\
\hline
\end{tabular}

\begin{tabular}{|c|c|c|c|}
\hline \multicolumn{3}{|c|}{ Notícia no 12 } \\
\hline Dia: 29 & Página: 22 & Caderno: Cidades & Possui Fotos: Sim \\
\hline \multicolumn{2}{|l|}{ Título: Chuva flagela em Brazlândia } \\
\hline
\end{tabular}


Informações adicionais: Água da chuva alagou casas e força da enxurrada derrubou barracos na quadra 6 do Setor Norte de Brazlândia. Moradores ficaram assustados e alguns precisaram deixar suas casas.

Desastre(s) Natural(is) associado(s) à reportagem: Alagamento, enxurrada.

Região(ões) Administrativa(s) afetada(s): Brazlândia (RA IV).

Referência bibliográfica: COSTA, Netto. Chuva flagela em Brazlândia. Correio Braziliense, Brasília, 16 de dez. de 2004. Cidades, p. 48.

\begin{tabular}{|c|c|c|c|}
\hline \multicolumn{4}{|c|}{ Notícia nำ 13} \\
\hline Dia: 27 & Página: 18 & Caderno: Cidades & Possui Fotos: Sim \\
\hline \multicolumn{4}{|c|}{ Título: Vento forte provoca prejuízo } \\
\hline \multicolumn{4}{|c|}{$\begin{array}{l}\text { Informações adicionais: Uma forte ventania assustou moradores das quadras } 103 \text {, } \\
\text { 104, } 303 \text { e } 304 \text { Norte. Houve queda de árvores e muitos prejuízos nas quadras: } \\
\text { fecharam ruas, balões, passeios e danificaram pelo menos quatro carros. }\end{array}$} \\
\hline \multicolumn{4}{|c|}{ Desastre(s) Natural(is) associado(s) à reportagem: Vendaval. } \\
\hline \multicolumn{4}{|c|}{ Região(ões) Administrativa(s) afetada(s): Brasília (RA I). } \\
\hline $\begin{array}{l}\text { Referênc } \\
\text { Braziliens }\end{array}$ & $\begin{array}{l}\text { liográfica: } A \\
\text { sília, } 27 \text { de }\end{array}$ & $\begin{array}{l}\text { Renato. Vento fort } \\
\text { 2004. Cidades, p. }\end{array}$ & prejuízo. Correio \\
\hline
\end{tabular}




\section{APÊNDICE VI}

Desastres Naturais relacionados às chuvas no Distrito Federal relatados no jornal Correio Braziliense no ano de 2005

Fevereiro

\begin{tabular}{|c|c|c|c|}
\hline \multicolumn{4}{|c|}{ Notícia $n^{\circ} 1$} \\
\hline Dia: 04 & Página: 23 & Caderno: Cidades & Possui Fotos: Sim \\
\hline \multicolumn{4}{|c|}{ Título: Ruas cobertas de lama em Vicente Pires } \\
\hline \multicolumn{4}{|c|}{$\begin{array}{l}\text { Informações adicionais: Após forte temporal na cidade de Vicente Pires os } \\
\text { moradores enfrentaram problemas como buracos, atoleiros e inundações em algumas } \\
\text { residências. }\end{array}$} \\
\hline \multicolumn{4}{|c|}{ Desastre(s) Natural(is) associado à reportagem: Alagamento. } \\
\hline \multicolumn{4}{|c|}{ Região(ões) Administrativa(s) afetada(s): Vicente Pires (RA XXX). } \\
\hline \multicolumn{4}{|c|}{$\begin{array}{l}\text { Referência bibliográfica: DUARTE, Marcela. Ruas cobertas de lama em Vicente } \\
\text { Pires. Correio Braziliense, Brasília, } 23 \text { de fev. de } 2005 \text {. Cidades, p. } 23 \text {. }\end{array}$} \\
\hline
\end{tabular}

\begin{tabular}{|c|c|c|c|}
\hline \multicolumn{4}{|c|}{ Notícia no 2} \\
\hline Dia: 20 & Página: 27 & Caderno: Cidades & Possui Fotos: Sim \\
\hline \multicolumn{4}{|c|}{ Título: Chuva causa transtornos. } \\
\hline \multicolumn{4}{|c|}{$\begin{array}{l}\text { Informações adicionais: Forte chuva provocou rachaduras em prédio no Setor de } \\
\text { Oficinas Norte. Durante o mesmo dia a chuva ocasionou pequenos alagamentos em } \\
\text { certas localidades do DF. }\end{array}$} \\
\hline \multicolumn{4}{|c|}{ Desastre(s) Natural(is) associado(s) à reportagem: Alagamento. } \\
\hline \multicolumn{4}{|c|}{ Região(ões) Administrativa(s) afetada(s): Brasília (RA I). } \\
\hline $\begin{array}{l}\text { Referênc } \\
\text { Braziliens }\end{array}$ & $\begin{array}{l}\text { bliográfica: } F \\
\text { asília, } 20 \text { de } f\end{array}$ & $\begin{array}{l}\text { IRA, Daniel. Chuva c } \\
\text { 2005. Cidades, p. } 20\end{array}$ & anstornos. Correio \\
\hline
\end{tabular}

\begin{tabular}{|c|c|c|c|}
\hline \multicolumn{3}{|c|}{ Notícia no 3} \\
\hline Dia: 28 & Página: 18 & Caderno: Cidades & Possui Fotos: Sim \\
\hline Título: Medo e prejuízos em cinco horas de temporal. \\
\hline \multicolumn{2}{|l|}{ Informações adicionais: Temporal que atingiu diversas cidades do Distrito Federal } \\
\hline
\end{tabular}


provocou alagamentos, desabamento de muros e carros quebrados em diversos pontos da cidade. A região de Sobradinho foi a mais afetada, de modo que a população teve inúmeros prejuízos. Moradores relataram que o nível da água atingiu $30 \mathrm{~cm}$ de altura arrastando os moveis das residências.

Desastre(s) Natural(is) associado(s) à reportagem: Alagamento.

Região(ões) Administrativa(s) afetada(s): Sobradinho (RA V).

Referência bibliográfica: REDAÇÃO. Medo e prejuízos em cinco horas de temporal. Correio Braziliense, Brasília, 28 de fev. de 2005. Cidades, p. 18.

Março

\begin{tabular}{|c|c|c|c|}
\hline \multicolumn{4}{|c|}{ Notícia n 4} \\
\hline Dia: 02 & Página: 28 & Caderno: Cidades & Possui Fotos: Sim \\
\hline \multicolumn{4}{|c|}{ Título: Temporais assustam moradores. } \\
\hline \multicolumn{4}{|c|}{$\begin{array}{l}\text { Informações adicionais: Fortes chuvas atingiram o Distrito Federal, segundo o Inmet, } \\
\text { choveu equivalente a } 36 \% \text { da média pluviométrica para o mês de março. Houve } \\
\text { diversas ocorrências de problemas relacionadas com a forte chuva, com enxurradas } \\
\text { no Vicente Pires e alagamentos em Sobradinho e no Plano Piloto. }\end{array}$} \\
\hline \multicolumn{4}{|c|}{ Desastre(s) Natural(is) associado(s) à reportagem: Alagamento, enxurrada. } \\
\hline \multicolumn{4}{|c|}{$\begin{array}{l}\text { Região(ões) Administrativa(s) afetada(s): Vicente Pires (RA XXX), Sobradinho (RA } \\
\text { V), Brasília (I). }\end{array}$} \\
\hline \multicolumn{4}{|c|}{$\begin{array}{l}\text { Referência bibliográfica: BRANDIM, Cecília. Temporais assustam moradores. } \\
\text { Correio Braziliense, Brasília, } 02 \text { de mar. de } 2005 \text {. Cidades, p. } 28 .\end{array}$} \\
\hline
\end{tabular}

\begin{tabular}{|c|c|c|c|}
\hline \multicolumn{3}{|c|}{ Notícia no 5} \\
\hline Dia: 08 & Página: 34 & Caderno: Cidades & Possui Fotos: Sim \\
\hline Título: Recorde de chuva em março. \\
\hline
\end{tabular}


VIII), Paranoá (RA VII).

Referência bibliográfica: MADER, Helena. Recorde de chuva em março. Correio Braziliense, Brasília, 03 de mar. de 2005. Cidades, p. 34.

\begin{tabular}{|c|c|c|c|}
\hline \multicolumn{4}{|c|}{ Notícia $n=6$} \\
\hline Dia: 12 & Página: 28 & Caderno: Cidades & Possui Fotos: Sim \\
\hline \multicolumn{4}{|c|}{ Título: Chuva abre cratera em rodovia. } \\
\hline \multicolumn{4}{|c|}{$\begin{array}{l}\text { Informações adicionais: Forte chuva culminou com a abertura de uma cratera na } \\
\text { rodovia DF-170 em área onde foi construído canalização para o córrego Taquara, } \\
\text { deixando os moradores isoladoras }\end{array}$} \\
\hline \multicolumn{4}{|c|}{ Desastre(s) Natural(is) associado(s) à reportagem: Erosão. } \\
\hline \multicolumn{4}{|c|}{ Região(ões) Administrativa(s) afetada(s): Brazlândia (RA IV). } \\
\hline
\end{tabular}

\begin{tabular}{|c|c|c|c|}
\hline \multicolumn{4}{|c|}{ Notícia nำ 7} \\
\hline Dia: 26 & Página: 26 & Caderno: Cidades & Possui Fotos: Sim \\
\hline \multicolumn{4}{|c|}{ Título: Vizinhos do perigo. } \\
\hline \multicolumn{4}{|c|}{$\begin{array}{l}\text { Informações adicionais: Defesa Civil trabalha em procedimentos para conter erosões } \\
\text { em Sobradinho II, que foram intensificadas com a forças das águas durante as fortes } \\
\text { chuvas que ocorreram no mês de março. }\end{array}$} \\
\hline \multicolumn{4}{|c|}{ Desastre(s) Natural(is) associado(s) à reportagem: Erosão. } \\
\hline \multicolumn{4}{|c|}{ Região(ões) Administrativa(s) afetada(s): Sobradinho II (RA XXVI). } \\
\hline \multicolumn{4}{|c|}{$\begin{array}{l}\text { Referência bibliográfica: BRANDIM, Cecília. Vizinhos do perigo. Correio Braziliense, } \\
\text { Brasília, } 26 \text { de mar. de } 2005 \text {. Cidades, p. } 26 .\end{array}$} \\
\hline
\end{tabular}


Setembro

\begin{tabular}{|c|c|c|c|}
\hline \multicolumn{4}{|c|}{ Notícia nㅇ 8} \\
\hline Dia: 24 & Página: 31 & Caderno: Cidades & Possui Fotos: Sim \\
\hline \multicolumn{4}{|c|}{ Título: Estragos do temporal. } \\
\hline \multicolumn{4}{|c|}{$\begin{array}{l}\text { Informações adicionais: Depois do forte temporal foi possível identificar danos } \\
\text { provocados pelas rajadas de vento que atingiram velocidades de até } 64 \mathrm{~km} / \mathrm{h} \text {. Foram } \\
\text { registradas quedas de árvores e outdoors, rompimento de fiações elétricas e muros } \\
\text { residenciais. }\end{array}$} \\
\hline \multicolumn{4}{|c|}{ Desastre(s) Natural(is) associado(s) à reportagem: Vendaval. } \\
\hline \multicolumn{4}{|c|}{ Região(ões) Administrativa(s) afetada(s): Sobradinho II (RA XXVI). } \\
\hline \multicolumn{4}{|c|}{$\begin{array}{l}\text { Referência bibliográfica: MADER, Helena. Estragos do temporal. Correio Braziliense, } \\
\text { Brasília, } 24 \text { de set. de } 2005 \text {. Cidades, p. } 31 .\end{array}$} \\
\hline
\end{tabular}

\section{Novembro}

\begin{tabular}{|c|c|c|c|}
\hline \multicolumn{4}{|c|}{ Notícia no 9} \\
\hline Dia: 21 & Página: 15 & Caderno: Cidades & Possui Fotos: Sim \\
\hline \multicolumn{4}{|c|}{ Título: Invasão de risco. } \\
\hline \multicolumn{4}{|c|}{$\begin{array}{l}\text { Informações adicionais: Moradores da Estrutural se reúnem com o apoio de } \\
\text { voluntário da Defesa Civil para evitar novos problemas causados pelas chuvas. O ato } \\
\text { serviu como medida provisória para se evitar alagamentos, criando barricadas para } \\
\text { diminuir a velocidade da água. }\end{array}$} \\
\hline \multicolumn{4}{|c|}{ Desastre(s) Natural(is) associado(s) à reportagem: Alagamento. } \\
\hline \multicolumn{4}{|c|}{ Região(ões) Administrativa(s) afetada(s): SCIA (RA XXV) } \\
\hline $\begin{array}{l}\text { Referênci } \\
\text { Brasília, } 2\end{array}$ & $\begin{array}{l}\text { bliográfica: } \\
\text { nov. de } 2005\end{array}$ & $\begin{array}{l}\text { JIM, Cecília. Invasão } \\
\text { des, p. } 15 .\end{array}$ & Correio Braziliense, \\
\hline
\end{tabular}

\begin{tabular}{|c|c|c|c|}
\hline \multicolumn{3}{|c|}{ Notícia no 10} \\
\hline Dia: 23 & Página: 29 & Caderno: Cidades & Possui Fotos: Sim \\
\hline \multicolumn{3}{|l|}{ Título: Chuva e caos no trânsito. } \\
\hline $\begin{array}{l}\text { Informações adicionais: Forte evento pluviométrico que atingiu diversas regiões do } \\
\text { DF acarretou em casos de alagamentos em cerca de } 30 \text { casas na Ceilândia, os }\end{array}$ \\
\hline
\end{tabular}


moradores reclamam do sistema de drenagem da cidade.

Desastre(s) Natural(is) associado(s) à reportagem: Alagamento.

Região(ões) Administrativa(s) afetada(s): Ceilândia (RA IX).

Referência bibliográfica: LIBRELON, Rachel e CARABALLO, Carolina. Chuva e caos no trânsito. Correio Braziliense, Brasília, 23 de nov. de 2005. Cidades, p. 29.

\section{Dezembro}

\begin{tabular}{|c|c|c|c|}
\hline \multicolumn{4}{|c|}{ Notícia nº 11} \\
\hline Dia: 15 & Página: 38 & Caderno: Cidades & Possui Fotos: Sim \\
\hline \multicolumn{4}{|c|}{ Título: Buracos viram caso de polícia. } \\
\hline \multicolumn{4}{|c|}{$\begin{array}{l}\text { Informações adicionais: Vários buracos provocados pela ação das chuvas ocorreram } \\
\text { em regiões do DF, gerando inúmeros problemas de transito e incomodo para os } \\
\text { motoristas. }\end{array}$} \\
\hline \multicolumn{4}{|c|}{ Desastre(s) Natural(is) associado(s) à reportagem: Alagamento. } \\
\hline \multicolumn{4}{|c|}{ Região(ões) Administrativa(s) afetada(s): Brasília (RA I) } \\
\hline \multicolumn{4}{|c|}{$\begin{array}{l}\text { Referência bibliográfica: BERNARDES, Adriana. Buracos viram caso de polícia. } \\
\text { Correio Braziliense, Brasília, } 15 \text { de dez. de } 2005 \text {. Cidades, p. } 38 \text {. }\end{array}$} \\
\hline
\end{tabular}

\begin{tabular}{|c|c|c|c|}
\hline \multicolumn{4}{|c|}{ Notícia nํ 12} \\
\hline Dia: 21 & Página: 15 & Caderno: Cidades & Possui Fotos: Sim \\
\hline \multicolumn{4}{|c|}{ Título: Invasão de risco. } \\
\hline \multicolumn{4}{|c|}{$\begin{array}{l}\text { Informações adicionais: Moradores da Estrutural se reúnem com o apoio de } \\
\text { voluntário da Defesa Civil para evitar novos problemas causados pelas chuvas. O ato } \\
\text { serviu como medida provisória para se evitar alagamentos, criando barricadas para } \\
\text { diminuir a velocidade da água. }\end{array}$} \\
\hline \multicolumn{4}{|c|}{ Desastre(s) Natural(is) associado(s) à reportagem: Alagamento. } \\
\hline \multicolumn{4}{|c|}{ Região(ões) Administrativa(s) afetada(s): SCIA (RA XXV) } \\
\hline $\begin{array}{l}\text { Referênc } \\
\text { Brasília, } 2\end{array}$ & $\begin{array}{l}\text { ibliográfica: } \mathrm{E} \\
\text { e dez. de } 2005\end{array}$ & $\begin{array}{l}\text { JIM, Cecília. Invasão } \\
\text { des, p. } 15 .\end{array}$ & Correio Braziliense, \\
\hline
\end{tabular}




\begin{tabular}{l|l|l|l} 
Dia: 23 & Página: 27 & Caderno: Cidades & Possui Fotos: Sim
\end{tabular}

Título: Primavera com chuva e granizo.

Informações adicionais: Chuva com granizo provocou longos congestionamentos e quedas de energia. O temporal gerou danos em alguns veículos e residências.

Desastre(s) Natural(is) associado(s) à reportagem: Granizo.

Região(ões) Administrativa(s) afetada(s): Brasília (RA I)

Referência bibliográfica: REDAÇÃO. Primavera com chuva e granizo. Correio Braziliense, Brasília, 23 de dez. de 2005. Cidades, p. 27.

\begin{tabular}{|c|c|c|c|}
\hline \multicolumn{4}{|c|}{ Notícia n 14} \\
\hline Dia: 21 & Página: 15 & Caderno: Cidades & Possui Fotos: Sim \\
\hline \multicolumn{4}{|c|}{ Título: Chuva forte e ventos de $79 \mathrm{~km} / \mathrm{h}$. } \\
\hline \multicolumn{4}{|c|}{$\begin{array}{l}\text { Informações adicionais: Com a mudança de tempo, a chuva veio acompanhada com } \\
\text { fortes ventos provocaram queda de árvores no centro do Plano Piloto provocando } \\
\text { incontáveis danos aos moradores. }\end{array}$} \\
\hline \multicolumn{4}{|c|}{ Desastre(s) Natural(is) associado(s) à reportagem: Vendaval. } \\
\hline \multicolumn{4}{|c|}{ Região(ões) Administrativa(s) afetada(s): Brasília (RA I) } \\
\hline \multicolumn{4}{|c|}{$\begin{array}{l}\text { Referência bibliográfica: DUARTE, Flávia. Chuva forte e ventos de } 79 \mathrm{~km} / \mathrm{h} \text {. Correio } \\
\text { Braziliense, Brasília, } 21 \text { de dez. de } 2005 \text {. Cidades, p. } 15 \text {. }\end{array}$} \\
\hline
\end{tabular}

\begin{tabular}{|c|c|c|c|}
\hline \multicolumn{4}{|c|}{ Notícia nำ 15} \\
\hline Dia: 20 & Página: 26 & Caderno: Cidades & Possui Fotos: Sim \\
\hline \multicolumn{4}{|c|}{ Título: Mais um mês de ventos fortes. } \\
\hline \multicolumn{4}{|c|}{$\begin{array}{l}\text { Informações adicionais: Fortes ventos que atingiram o Plano Piloto levou a queda de } \\
\text { diversas árvores, fator que impediu o trafego de veículos em certas vias e em alguns } \\
\text { casos danificou os carros completamente. }\end{array}$} \\
\hline \multicolumn{4}{|c|}{ Desastre(s) Natural(is) associado(s) à reportagem: Vendaval. } \\
\hline \multicolumn{4}{|c|}{ Região(ões) Administrativa(s) afetada(s): Brasília (RA I) } \\
\hline Referênci & liográfica: $\mathrm{C}$ & E, Marcela. Mais um & ventos fortes. Correio \\
\hline
\end{tabular}


Braziliense, Brasília, 20 de dez. de 2005. Cidades, p. 26. 


\section{APÊNDICE VII}

\section{Desastres Naturais relacionados às chuvas no Distrito Federal relatados no jornal Correio Braziliense no ano de 2006}

Janeiro

\begin{tabular}{|c|c|c|c|}
\hline \multicolumn{4}{|c|}{ Notícia no 1} \\
\hline Dia: 04 & Página: 20 & Caderno: Cidades & Possui Fotos: Sim \\
\hline \multicolumn{4}{|c|}{ Título: Alerta: crateras e tempestades. } \\
\hline \multicolumn{4}{|c|}{$\begin{array}{l}\text { Informações adicionais: Brasília enfrentou o caos em mais uma tarde de chuva, que } \\
\text { formou uma cratera na pista da que dá acesso ao Eixinho. A chuva também causou } \\
\text { três acidentes de trânsito graves e teve ventos de até } 60 \mathrm{~km} / \mathrm{h} \text { de acordo com o } \\
\text { INMET. }\end{array}$} \\
\hline \multicolumn{4}{|c|}{ Desastre(s) Natural(is) associado(s) à reportagem: Vendaval. } \\
\hline \multicolumn{4}{|c|}{$\begin{array}{l}\text { Região(ões) Administrativa(s) afetada(s): Brasília (RA I), Setor Complementar de } \\
\text { Indústria e Abastecimento (RA XXV). }\end{array}$} \\
\hline \multicolumn{4}{|c|}{$\begin{array}{l}\text { Referência bibliográfica: CARABALLO, Carolina. Alerta: crateras e tempestades. } \\
\text { Correio Braziliense, Brasília, } 04 \text { de jan. de 2006. Cidades, p. } 20 .\end{array}$} \\
\hline
\end{tabular}

\begin{tabular}{|c|c|c|c|}
\hline \multicolumn{4}{|c|}{ Notícia n 2} \\
\hline Dia: 11 & Página: 24 & Caderno: Cidades & Possui Fotos: Sim \\
\hline \multicolumn{4}{|c|}{ Título: Moradores temem o avanço de erosão na Ceilândia } \\
\hline \multicolumn{4}{|c|}{$\begin{array}{l}\text { Informações adicionais: Erosões são aumentadas pela chuva no condomínio Privê, } \\
\text { ameaçando a segurança das casas próximas. Moradores afirmam que quando chove } \\
\text { a área fica tomada pela lama. Enxurrada que desce do Setor O também ameaça } \\
\text { nascente próxima ao condomínio. Administração tenta amenizar a situação das } \\
\text { erosões entulhando as crateras. }\end{array}$} \\
\hline \multicolumn{4}{|c|}{ Desastre(s) Natural(is) associado(s) à reportagem: Enxurrada, erosão. } \\
\hline \multicolumn{4}{|c|}{ Região(ões) Administrativa(s) afetada(s): Ceilândia (RA IX). } \\
\hline \multicolumn{4}{|c|}{$\begin{array}{l}\text { Referência bibliográfica: BERNARDES, Adriana. Moradores temem o avanço de } \\
\text { erosão na Ceilândia. Correio Braziliense, Brasília, } 11 \text { de jan. de 2006. Cidades, p. } 24 \text {. }\end{array}$} \\
\hline
\end{tabular}




\section{Notícia n으 3}

\begin{tabular}{c|c|c|c} 
Dia: 27 & Página: 30 & Caderno: Cidades & Possui Fotos: Não \\
\hline
\end{tabular}

Título: Pancadas de chuva no fim da tarde

Informações adicionais: Pancadas de chuva ocorreram no fim da tarde em várias cidades do DF, deixando o trânsito mais lento e as ruas alagadas.

Desastre(s) Natural(is) associado(s) à reportagem: Alagamento.

Região(ões) Administrativa(s) afetada(s): Taguatinga (RA III).

Referência bibliográfica: REDAÇÃO. Pancadas de chuva no fim da tarde. Correio Braziliense, Brasília, 27 de jan. de 2006. Cidades, p. 30.

\begin{tabular}{|c|c|c|c|}
\hline \multicolumn{4}{|c|}{ Notícia no 4} \\
\hline Dia: 28 & Página: 29 & Caderno: Cidades & Possui Fotos: Não \\
\hline \multicolumn{4}{|c|}{ Título: Estragos no rastro da chuva } \\
\hline \multicolumn{4}{|c|}{$\begin{array}{l}\text { Informações adicionais: Bombeiros registram } 22 \text { ocorrências devido às fortes } \\
\text { rajadas de vento da chuva, a maioria relacionada a destelhamento de } \\
\text { estabelecimentos e casas. De acordo com o INMET, a chuva foi provocada pelo fim de } \\
\text { um veranico pela concentração de nuvens que se chocaram com o ar quente. }\end{array}$} \\
\hline \multicolumn{4}{|c|}{ Desastre(s) Natural(is) associado(s) à reportagem: Vendaval. } \\
\hline \multicolumn{4}{|c|}{$\begin{array}{l}\text { Região(ões) Administrativa(s) afetada(s): Recanto das Emas (RA XV), Riacho } \\
\text { Fundo II (RA XXI), Samambaia (RA XII). }\end{array}$} \\
\hline \multicolumn{4}{|c|}{$\begin{array}{l}\text { Referência bibliográfica: FERRI, Maria; LIBRELON, Rachel. Estragos no rastro da } \\
\text { chuva. Correio Braziliense, Brasília, } 28 \text { de jan. de 2006. Cidades, p. } 29 .\end{array}$} \\
\hline
\end{tabular}

\begin{tabular}{|c|c|c|c|}
\hline \multicolumn{4}{|c|}{ Notícia nะ 5} \\
\hline Dia: 28 & Página: 29 & Caderno: Cidades & Possui Fotos: Sim \\
\hline \multicolumn{4}{|c|}{ Título: Uma pancada e o galo na cabeça } \\
\hline \multicolumn{4}{|c|}{$\begin{array}{l}\text { Informações adicionais: Chuva provocou diversos destelhamentos de casas no } \\
\text { Riacho Fundo II, trazendo muitos prejuízos aos moradores. }\end{array}$} \\
\hline \multicolumn{4}{|c|}{ Desastre(s) Natural(is) associado(s) à reportagem: Vendaval. } \\
\hline \multicolumn{4}{|c|}{ Região(ões) Administrativa(s) afetada(s): Riacho Fundo II (RA XXI). } \\
\hline
\end{tabular}


Referência bibliográfica: FERRI, Maria; LIBRELON, Rachel. Uma pancada e o galo na cabeça. Correio Braziliense, Brasília, 28 de jan. de 2006. Cidades, p. 29.

\section{Fevereiro}

\begin{tabular}{|c|c|c|c|}
\hline \multicolumn{4}{|c|}{ Notícia nㅇ 6} \\
\hline Dia: 01 & Página: 26 & Caderno: Cidades & Possui Fotos: Sim \\
\hline \multicolumn{4}{|c|}{ Título: Chuva continua hoje } \\
\hline \multicolumn{4}{|c|}{$\begin{array}{l}\text { Informações adicionais: Chuva de três horas causa acidentes de trânsito, } \\
\text { alagamentos e impede o trânsito em diversas vias. De acordo com o Instituto Nacional } \\
\text { de Meteorologia, apesar das fortes chuvas, janeiro ficou aquém da média }(241,4 \mathrm{~mm}) \\
\text { e registrou } 123,2 \mathrm{~mm} \text { de precipitação. }\end{array}$} \\
\hline \multicolumn{4}{|c|}{ Desastre(s) Natural(is) associado(s) à reportagem: Alagamento. } \\
\hline \multicolumn{4}{|c|}{ Região(ões) Administrativa(s) afetada(s): Brasília (RA I), Lago Sul (RA XVI). } \\
\hline $\begin{array}{l}\text { Referênc } \\
\text { Brasília, } 1\end{array}$ & $\begin{array}{l}\text { bliográfica: } \\
\text { fev. de } 2006 \text {. }\end{array}$ & $\begin{array}{l}\text { IRA, Ary. Chuva cc } \\
\text { s, p. } 26 .\end{array}$ & e. Correio Braziliense, \\
\hline
\end{tabular}

\begin{tabular}{|c|c|c|c|}
\hline \multicolumn{4}{|c|}{ Notícia no 7} \\
\hline Dia: 02 & Página: 32 & Caderno: Cidades & Possui Fotos: Sim \\
\hline \multicolumn{4}{|c|}{ Título: Noite de apagões e alagamentos } \\
\hline \multicolumn{4}{|c|}{$\begin{array}{l}\text { Informações adicionais: Forte chuva alaga diversos pontos do Distrito Federal e } \\
\text { ocasiona queda de energia em oito localidades. Chuva foi provocada pela chegada de } \\
\text { uma frente fria à capital aliada a zonas de instabilidade da Amazônia, de acordo com o } \\
\text { Instituto Nacional de Meteorologia. }\end{array}$} \\
\hline \multicolumn{4}{|c|}{ Desastre(s) Natural(is) associado(s) à reportagem: Alagamento. } \\
\hline \multicolumn{4}{|c|}{$\begin{array}{l}\text { Região(ões) Administrativa(s) afetada(s): Brasília (RA I), Gama (RA II), Guará (RA } \\
\text { X), Park Way (XXIV), Samambaia (RA XII). }\end{array}$} \\
\hline \multicolumn{4}{|c|}{$\begin{array}{l}\text { Referência bibliográfica: BERNARDES, Adriana; GOULART, Guilherme. Noite de } \\
\text { apagões e alagamentos. Correio Braziliense, Brasília, } 02 \text { de fev. de 2006. Cidades, p. } \\
32 .\end{array}$} \\
\hline
\end{tabular}




\section{Notícia no 8}

\begin{tabular}{l|l|l|l} 
Dia: 09 & Página: 34 & Caderno: Cidades & Possui Fotos: Não
\end{tabular}

Título: Chuva alaga parte de shopping

Informações adicionais: Temporal provoca alagamentos e apagões em diversas localidades do Distrito Federal. Houve quedas de energia no Plano Piloto e Paranoá, luzes da Ponte JK ficaram desligadas e um shopping no Jardim Botânico ficou parcialmente alagado.

Desastre(s) Natural(is) associado(s) à reportagem: Alagamento.

Região(ões) Administrativa(s) afetada(s): Brasília (RA I), Lago Sul (RA XVI), Jardim Botânico (RA XXVII), Paranoá (RA VII).

Referência bibliográfica: REDAÇÃO. Chuva alaga parte de shopping. Correio Braziliense, Brasília, 09 de fev. de 2006. Cidades, p. 34.

\begin{tabular}{|c|c|c|c|}
\hline \multicolumn{4}{|c|}{ Notícia n 9} \\
\hline Dia: 10 & Página: 25 & Caderno: Cidades & Possui Fotos: Sim \\
\hline \multicolumn{4}{|c|}{ Título: Destruição no rastro da chuva } \\
\hline \multicolumn{4}{|c|}{$\begin{array}{l}\text { Informações adicionais: Segundo o INMET, choveu em uma hora } 22,1 \mathrm{~mm} \text {, } \\
\text { quantidade considerada moderada. Houve queda de árvores no Paranoá e de energia } \\
\text { em } 12 \text { localidades. }\end{array}$} \\
\hline \multicolumn{4}{|c|}{ Desastre(s) Natural(is) associado(s) à reportagem: Vendaval. } \\
\hline \multicolumn{4}{|c|}{$\begin{array}{l}\text { Região(ões) Administrativa(s) afetada(s): Brasília (RA I), Gama (RA II), Guará (RA } \\
\text { X), Lago Sul (RA XVI), Lago Norte (RA XVIII), Núcleo Bandeirante (RA VIII), Paranoá } \\
\text { (RA VII), Planaltina (RA VI), São Sebastião (RA XIV), Sobradinho (RA V). }\end{array}$} \\
\hline \multicolumn{4}{|c|}{$\begin{array}{l}\text { Referência bibliográfica: COELHO, Mário. Destruição no rastro da chuva. Correio } \\
\text { Braziliense, Brasília, } 10 \text { de fev. de 2006. Cidades, p. } 25 \text {. }\end{array}$} \\
\hline
\end{tabular}

\begin{tabular}{|c|c|c|c|}
\hline \multicolumn{3}{|c|}{ Notícia no 10} \\
\hline Dia: 11 & Página: 31 & Caderno: Cidades & Possui Fotos: Sim \\
\hline Título: Carros são arrastados pela água \\
\hline $\begin{array}{l}\text { Informações adicionais: Chuva inunda partes da via estrutural e do Setor de Oficinas } \\
\text { Sul. Em cerca de uma hora, choveu cerca de } 33 \mathrm{~mm} \text { de chuva, metade da quantidade } \\
\text { de chuva que caiu no dia 1ํ de fevereiro, cerca de } 62 \mathrm{~mm} \text {, de acordo com o INMET, }\end{array}$ \\
\hline
\end{tabular}


que também considerou a chuva normal para o período.

Desastre(s) Natural(is) associado(s) à reportagem: Alagamento.

Região(ões) Administrativa(s) afetada(s): Guará (RA X), Setor Complementar de Indústria e Abastecimento (RA XXV).

Referência bibliográfica: CARABALLO, Carolina. Noite de apagões e alagamentos. Correio Braziliense, Brasília, 11 de fev. de 2006. Cidades, p. 31.

\begin{tabular}{|c|c|c|c|}
\hline \multicolumn{4}{|c|}{ Notícia n 11} \\
\hline Dia: 12 & Página: 30 & Caderno: Cidades & Possui Fotos: Sim \\
\hline \multicolumn{4}{|c|}{ Título: Construção civil, a maior vilã } \\
\hline \multicolumn{4}{|c|}{$\begin{array}{l}\text { Informações adicionais: "O número de erosões chega a crescer } 10 \% \text { no período } \\
\text { chuvoso", de acordo com Elidiane Martins, pesquisadora da Universidade de Brasília. } \\
\text { As erosões não são apenas naturais, porque muitas são provocadas pelas retirada de } \\
\text { materiais usados na construção civil (cerca de } 34 \% \text { dos } 34,7 \mathrm{~km} \text { dos solos degradados } \\
\text { no DF). Áreas mais afetadas são a Ceilândia e o ltapoã. }\end{array}$} \\
\hline \multicolumn{4}{|c|}{ Desastre(s) Natural(is) associado(s) à reportagem: Erosão. } \\
\hline \multicolumn{4}{|c|}{ Região(ões) Administrativa(s) afetada(s): Ceilândia (RA IX), Itapoã (RA XXVII). } \\
\hline $\begin{array}{l}\text { Referênci } \\
\text { Braziliens }\end{array}$ & $\begin{array}{l}\text { bliográfica: } \\
\text { rasília, } 12 \text { de }\end{array}$ & $\begin{array}{l}\text { ON, Rachel. Constru } \\
\text { 2006. Cidades, p. } 30\end{array}$ & , a maior vilã. Correio \\
\hline
\end{tabular}

\begin{tabular}{|c|c|c|c|}
\hline \multicolumn{4}{|c|}{ Notícia nำ 12} \\
\hline Dia: 12 & Página: 30 & Caderno: Cidades & Possui Fotos: Sim \\
\hline \multicolumn{4}{|c|}{ Título: Desgaste por todo lado } \\
\hline \multicolumn{4}{|c|}{$\begin{array}{l}\text { Informações adicionais: Entre dois condomínios no Jardim Botânico, a chuva formou } \\
\text { uma erosão de } 50 \text { metros de extensão. No Gama, há uma erosão de } 30 \text { metros de } \\
\text { extensão por } 10 \text { de profundidade que está aumentando. Em Sobradinho a enxurrada } \\
\text { que desce da DF-150 aumenta a erosão dos fundos do condomínio Beija-Flor. No } \\
\text { Setor O uma erosão cresce sobre uma área na qual vivem } 120 \text { famílias, que precisam } \\
\text { ser desalojadas. Moradores jogam lixo e usam sacos de areia na tentativa de conter } \\
\text { as erosões. }\end{array}$} \\
\hline \multicolumn{4}{|c|}{ Desastre(s) Natural(is) associado(s) à reportagem: Enxurrada, erosão. } \\
\hline \multicolumn{4}{|c|}{$\begin{array}{l}\text { Região(ões) Administrativa(s) afetada(s): Ceilândia (RA IX), Gama (RA II), Jardim } \\
\text { Botânico (RA XXVII), Sobradinho (RA V). }\end{array}$} \\
\hline
\end{tabular}


Referência bibliográfica: LIBRELON, Rachel. Desgaste por todo lado. Correio Braziliense, Brasília, 12 de fev. de 2006. Cidades, p. 30.

\begin{tabular}{|c|c|c|c|}
\hline \multicolumn{4}{|c|}{ Notícia nº 13} \\
\hline Dia: 15 & Página: 31 & Caderno: Cidades & Possui Fotos: \\
\hline \multicolumn{4}{|c|}{ Título: Em alerta contra os dias de chuva } \\
\hline \multicolumn{4}{|c|}{$\begin{array}{l}\text { Informações adicionais: O INMET informa que apesar das chuvas intensas e } \\
\text { constantes, o mês de janeiro teve menos chuvas em } 2006 \text { (122 mm) que no ano de } \\
2005 \text { (342 mm). }\end{array}$} \\
\hline \multicolumn{4}{|c|}{ Desastre(s) Natural(is) associado(s) à reportagem: Enxurrada. } \\
\hline \multicolumn{4}{|c|}{$\begin{array}{l}\text { Região(ões) Administrativa(s) afetada(s): Setor Complementar de Indústria e } \\
\text { Abastecimento (RA XXV). }\end{array}$} \\
\hline \multicolumn{4}{|c|}{$\begin{array}{l}\text { Referência bibliográfica: FLECK, Isabel. Em alerta contra os dias de chuva. Correio } \\
\text { Braziliense, Brasília, } 15 \text { de fev. de } 2006 \text {. Cidades, p. } 31 \text {. }\end{array}$} \\
\hline
\end{tabular}

\begin{tabular}{|c|c|c|c|}
\hline \multicolumn{4}{|c|}{ Notícia no 14} \\
\hline Dia: 21 & Página: 56 & Caderno: Cidades & Possui Fotos: Sim \\
\hline \multicolumn{4}{|c|}{ Título: Vento derruba casa e muros na Ceilândia } \\
\hline \multicolumn{4}{|c|}{$\begin{array}{l}\text { Informações adicionais: Chuva forte trouxe ventos de } 50 \mathrm{~km} / \mathrm{h} \text { que derrubaram uma } \\
\text { casa e um muro na Ceilândia. Os efeitos piores foram sentidos no Setor O e no Setor } \\
\text { P Norte. }\end{array}$} \\
\hline \multicolumn{4}{|c|}{ Desastre(s) Natural(is) associado(s) à reportagem: Vendaval. } \\
\hline \multicolumn{4}{|c|}{ Região(ões) Administrativa(s) afetada(s): Ceilândia (RA IX). } \\
\hline \multicolumn{4}{|c|}{$\begin{array}{l}\text { Referência bibliográfica: DUARTE, Marcela. Vento derruba casa e muros na } \\
\text { Ceilândia. Correio Braziliense, Brasília, } 21 \text { de fev. de 2006. Cidades, p. } 32 .\end{array}$} \\
\hline
\end{tabular}

\section{Março}




\begin{tabular}{|c|c|c|c|}
\hline \multicolumn{4}{|c|}{ Notícia $\mathrm{n} \div 15$} \\
\hline Dia: 09 & Página: 31 & Caderno: Cidades & Possui Fotos: Sim \\
\hline \multicolumn{4}{|c|}{ Título: Casas inundadas e ruas alagadas. } \\
\hline \multicolumn{4}{|c|}{$\begin{array}{l}\text { Informações adicionais: A chuva derrubou muros no Lago Norte e no Varjão. A } \\
\text { estação do INMET registrou 11,2 mm de chuva. Ainda de acordo com o instituto, em } \\
\text { janeiro e fevereiro de } 2006 \text { choveram } 236,5 \mathrm{~mm} \text { de chuva, } 51,8 \% \text { da média histórica, } \\
\text { que é de } 451,6 \mathrm{~mm} \text {. }\end{array}$} \\
\hline \multicolumn{4}{|c|}{ Desastre(s) Natural(is) associado(s) à reportagem: Alagamento, enxurrada. } \\
\hline \multicolumn{4}{|c|}{$\begin{array}{l}\text { Região(ões) Administrativa(s) afetada(s): Brasília (RA I), Lago Norte (RA XVIII), } \\
\text { Varjão (RA XXIII). }\end{array}$} \\
\hline \multicolumn{4}{|c|}{$\begin{array}{l}\text { Referência bibliográfica: REBELLO, Pablo. Noite de apagões e alagamentos. } \\
\text { Correio Braziliense, Brasília, } 09 \text { de mar. de } 2006 \text {. Cidades, p. } 31 .\end{array}$} \\
\hline
\end{tabular}

\begin{tabular}{|c|c|c|c|}
\hline \multicolumn{4}{|c|}{ Notícia nº 16} \\
\hline Dia: 31 & Página: 32 & Caderno: Cidades & Possui Fotos: Sim \\
\hline \multicolumn{4}{|c|}{ Título: Temporal assusta brasilienses } \\
\hline \multicolumn{4}{|c|}{$\begin{array}{l}\text { Informações adicionais: Chuva inundou o Venâncio 3000, o Setor Bancário Sul e as } \\
\text { quadras } 201,702,202 \text { e } 402 \text { na Asa Norte e } 402 \text { e } 102 \text { na Asa Sul e também a DF- } \\
250 \text { entre o Paranoá e o Itapoã. Segundo o INMET, choveu cerca de } 42,7 \mathrm{~mm} \text {. A } \\
\text { chuva foi provocada pela passagem de uma frente fria pelo Centro-Oeste. A média de } \\
\text { março era de } 189,9 \mathrm{~mm} \text {, mas até o dia } 30 \text { já havia chovido } 260,7 \mathrm{~mm} \text { no mês. }\end{array}$} \\
\hline \multicolumn{4}{|c|}{ Desastre(s) Natural(is) associado(s) à reportagem: Alagamento, enxurrada. } \\
\hline \multicolumn{4}{|c|}{$\begin{array}{l}\text { Região(ões) Administrativa(s) afetada(s): Brasília (RA I), Paranoá (RA XVII), Itapoã } \\
\text { (RA XXVII). }\end{array}$} \\
\hline \multicolumn{4}{|c|}{$\begin{array}{l}\text { Referência bibliográfica: COELHO, Mário; FERRI, Maria. Temporal assusta } \\
\text { brasilienses. Correio Braziliense, Brasília, } 31 \text { de mar. de 2006. Cidades, p. } 32 .\end{array}$} \\
\hline
\end{tabular}

Abril 


\begin{tabular}{|c|c|c|c|}
\hline \multicolumn{4}{|c|}{ Notícia nำ 17} \\
\hline Dia: 01 & Página: 32 & Caderno: Cidades & Possui Fotos: Sim \\
\hline \multicolumn{4}{|c|}{ Título: Chuva no fim de semana } \\
\hline \multicolumn{4}{|c|}{$\begin{array}{l}\text { Informações adicionais: Chuvas fortes ocorrem no Distrito Federal devido a zonas } \\
\text { de instabilidade que estão atuando sobre o Centro-Oeste. Chuva alagou parte das } \\
\text { quadras } 402 \text { e } 407 \text { Norte. }\end{array}$} \\
\hline \multicolumn{4}{|c|}{ Desastre(s) Natural(is) associado(s) à reportagem: Alagamento. } \\
\hline \multicolumn{4}{|c|}{ Região(ões) Administrativa(s) afetada(s): Brasília (RA I). } \\
\hline \multicolumn{4}{|c|}{$\begin{array}{l}\text { Referência bibliográfica: REDAÇÃO. Noite de apagões e alagamentos. Correio } \\
\text { Braziliense, Brasília, 1ํ de abr. de } 2006 \text {. Cidades, p. } 32 \text {. }\end{array}$} \\
\hline
\end{tabular}

\section{Agosto}

\begin{tabular}{|c|c|c|c|}
\hline \multicolumn{4}{|c|}{ Notícia nำ 18} \\
\hline Dia: 25 & Página: 30 & Caderno: Cidades & Possui Fotos: Sim \\
\hline \multicolumn{4}{|c|}{ Título: Temporal complica fim de tarde em Brasília } \\
\hline \multicolumn{4}{|c|}{$\begin{array}{l}\text { Informações adicionais: De acordo com o INMET, em uma hora, choveu } 42 \mathrm{~mm} \text {, } \\
\text { mais que o dobro da média de agosto que é de } 12 \mathrm{~mm} \text {. A chuva derrubou um outdoor } \\
\text { no Setor de Indústrias Gráficas, alagou parte do viaduto Ayrton Senna no Cruzeiro e } \\
\text { complicou a volta para casa do brasiliense. }\end{array}$} \\
\hline \multicolumn{4}{|c|}{ Desastre(s) Natural(is) associado(s) à reportagem: Alagamento. } \\
\hline \multicolumn{4}{|c|}{$\begin{array}{l}\text { Região(ões) Administrativa(s) afetada(s): Brasília (RA I), Cruzeiro (RA XI), Setor de } \\
\text { Indústria e Abastecimento (RA XXIX). }\end{array}$} \\
\hline \multicolumn{4}{|c|}{$\begin{array}{l}\text { Referência bibliográfica: FILGUEIRA, Ary. Temporal complica fim de tarde em } \\
\text { Brasília. Correio Braziliense, Brasília, } 25 \text { de ago. de 2006. Cidades, p. } 30 .\end{array}$} \\
\hline
\end{tabular}

\section{Outubro}

\begin{tabular}{|c|c|c|c|}
\hline \multicolumn{3}{|c|}{ Notícia no 19 } \\
\hline Dia: 14 & Página: 25 & Caderno: Cidades & Possui Fotos: Sim \\
\hline Título: Previsão é de ainda mais chuva \\
\hline
\end{tabular}


em 12 dias choveu $195 \mathrm{~mm}$, mais do que o esperado para o mês de outubro no DF, que é de $172 \mathrm{~mm}$. As chuvas devem continuar, impulsionadas pelas áreas de instabilidade que estão atuando sobre a região Centro-Oeste. No último sábado choveu $70 \mathrm{~mm}$, maior quantidade diária do ano.

Desastre(s) Natural(is) associado(s) à reportagem: Alagamento, erosão.

Região(ões) Administrativa(s) afetada(s): Núcleo Bandeirante (RA VIII).

Referência bibliográfica: RODRIGUES, Gizella. Previsão é de ainda mais chuva. Correio Braziliense, Brasília, 14 de out. de 2006. Cidades, p. 25.

\begin{tabular}{|c|c|c|c|}
\hline \multicolumn{4}{|c|}{ Notícia n 20} \\
\hline Dia: 14 & Página: 26 & Caderno: Cidades & Possui Fotos: Não \\
\hline \multicolumn{4}{|c|}{ Título: Quando o endereço vira ameaça } \\
\hline \multicolumn{4}{|c|}{$\begin{array}{l}\text { Informações adicionais: Defesa Civil alerta para chuvas fortes que devem ocorrer e } \\
\text { mapeia áreas de risco do DF. } 34 \text { residências devem ser retiradas no Varjão e } 70 \\
\text { famílias devem ser desalojadas na Vila Rafael, em Ceilândia. }\end{array}$} \\
\hline \multicolumn{4}{|c|}{$\begin{array}{l}\text { Desastre(s) Natural(is) associado(s) à reportagem: Ceilândia (RA IX), Varjão } \\
(X X I I I) \text {. }\end{array}$} \\
\hline \multicolumn{4}{|c|}{ Região(ões) Administrativa(s) afetada(s): Alagamento, erosão. } \\
\hline $\begin{array}{l}\text { Referênci } \\
\text { Correio } B r\end{array}$ & $\begin{array}{l}\text { bliográfica: } F \\
\text { ense, Brasília }\end{array}$ & $\begin{array}{l}\text { GUES, Gizella. Quan } \\
\text { out. de 2006. Cidad }\end{array}$ & $\begin{array}{l}\text { dereço vira ameaça. } \\
\text { b. }\end{array}$ \\
\hline
\end{tabular}

\begin{tabular}{|c|c|c|c|}
\hline \multicolumn{4}{|c|}{ Notícia n 21} \\
\hline Dia: 16 & Página: 18 & Caderno: Cidades & Possui Fotos: Não \\
\hline \multicolumn{4}{|c|}{ Título: Previsão de muita chuva na semana } \\
\hline \multicolumn{4}{|c|}{$\begin{array}{l}\text { Informações adicionais: A enxurrada destruiu o piso de uma casa na Vila Cauhy. } \\
\text { INMET aponta frentes frias vindas dos polos associadas a zonas de instabilidade da } \\
\text { Amazônia como causa das constantes chuvas que caem na capital. }\end{array}$} \\
\hline \multicolumn{4}{|c|}{ Desastre(s) Natural(is) associado(s) à reportagem: Enxurrada. } \\
\hline \multicolumn{4}{|c|}{ Região(ões) Administrativa(s) afetada(s): Núcleo Bandeirante (RA VIII). } \\
\hline \multicolumn{4}{|c|}{$\begin{array}{l}\text { Referência bibliográfica: REDAÇÃO. Previsão de muita chuva na semana. Correic } \\
\text { Braziliense, Brasília, } 16 \text { de out. de } 2006 \text {. Cidades, p. } 18 \text {. }\end{array}$} \\
\hline
\end{tabular}




\begin{tabular}{|c|c|c|c|}
\hline \multicolumn{4}{|c|}{ Notícia n으 22} \\
\hline Dia: 18 & Página: 28 & Caderno: Cidades & Possui Fotos: Sim \\
\hline \multicolumn{4}{|c|}{ Título: Destruição em Samambaia } \\
\hline \multicolumn{4}{|c|}{$\begin{array}{l}\text { Informações adicionais: Chuva destrói casa na quadra } 402 \text { da Samambaia. Água } \\
\text { também alagou outras casas e destruiu diversos móveis e eletrodomésticos. Além de } \\
\text { Samambaia, chuva alagou áreas de Taguatinga, Vicente Pires e Ceilândia. }\end{array}$} \\
\hline \multicolumn{4}{|c|}{ Desastre(s) Natural(is) associado(s) à reportagem: Alagamento, enxurrada. } \\
\hline \multicolumn{4}{|c|}{$\begin{array}{l}\text { Região(ões) Administrativa(s) afetada(s): Ceilândia (RA IX), Samambaia (RA XII), } \\
\text { Taguatinga (RA III), Vicente Pires (RA XXX). }\end{array}$} \\
\hline \multicolumn{4}{|c|}{$\begin{array}{l}\text { Referência bibliográfica: BEZERRA, André. Destruição em Samambaia. Correio } \\
\text { Braziliense, Brasília, } 18 \text { de out. de } 2006 \text {. Cidades, p. } 28 \text {. }\end{array}$} \\
\hline
\end{tabular}

\begin{tabular}{|c|c|c|c|}
\hline \multicolumn{4}{|c|}{ Notícia $\mathrm{n} \times 23$} \\
\hline Dia: 20 & Página: 30 & Caderno: Cidades & Possui Fotos: Sim \\
\hline \multicolumn{4}{|c|}{ Título: Alerta contra temporais. } \\
\hline \multicolumn{4}{|c|}{$\begin{array}{l}\text { Informações adicionais: Até o dia } 20 \text { já choveu } 271 \mathrm{~mm}, 57 \% \text { a mais do que o } \\
\text { esperado para o mês de outubro, que é de } 172 \mathrm{~mm} \text {. O INMET acredita que o El Niño } \\
\text { esteja influenciando o excesso de chuvas. Houve quedas de energia em vários pontos } \\
\text { do Plano Piloto e alagamentos em diversas cidades do Distrito Federal, principalmente } \\
\text { nas últimas quadras da Asa Norte. }\end{array}$} \\
\hline \multicolumn{4}{|c|}{ Desastre(s) Natural(is) associado(s) à reportagem: Alagamento. } \\
\hline \multicolumn{4}{|c|}{$\begin{array}{l}\text { Região(ões) Administrativa(s) afetada(s): Brasília (RA I), Ceilândia (RA IX), Núcleo } \\
\text { Bandeirante (RA VIII), Paranoá (RA VII), Planaltina (RA VI), Riacho Fundo (RA XVII), } \\
\text { Samambaia (RA XII), Setor Complementar de Indústria e Abastecimento (RA XXV), } \\
\text { Sobradinho (RA V), Taguatinga (RA III), Varjão (RA XVIII). }\end{array}$} \\
\hline \multicolumn{4}{|c|}{$\begin{array}{l}\text { Referência bibliográfica: REBELLO, Pablo. Alerta contra temporais. Correio } \\
\text { Braziliense, Brasília, } 20 \text { de out. de } 2006 \text {. Cidades, p. } 30 \text {. }\end{array}$} \\
\hline
\end{tabular}

\begin{tabular}{|c|c|c|c|}
\hline \multicolumn{3}{|c|}{ Notícia no 24} \\
\hline Dia: 24 & Página: 29 & Caderno: Cidades & Possui Fotos: Sim \\
\hline \multicolumn{2}{|l|}{ Título: Temporal acaba em destruição } \\
\hline
\end{tabular}


Informações adicionais: Na Fercal, transbordamento do córrego da Prainha desalojou 271 pessoas. No Núcleo Bandeirante, quatro famílias precisaram ser desalojadas. O córrego Vicente Pires também transbordou e a enxurrada retirou boa parte da cobertura de asfalto da área. A enxurrada também invadiu várias casas na quadra 402 de Samambaia. Entre domingo e segunda choveu cerca de $85 \mathrm{~mm}$. De acordo com o INMET, até o dia 23 de outubro já havia chovido $373 \mathrm{~mm}$ no Distrito Federal, $116 \%$ acima da média do mês (172 mm).

Desastre(s) Natural(is) associado(s) à reportagem: Enxurrada.

Região(ões) Administrativa(s) afetada(s): Núcleo Bandeirante (RA VIII), Samambaia (RA XII), Vicente Pires (RA XXX), Fercal (RA XXXI).

Referência bibliográfica: BEZERRA, André. Temporal acaba em destruição. Correio Braziliense, Brasília, 24 de out. de 2006. Cidades, p. 29.

\begin{tabular}{|c|c|c|c|}
\hline \multicolumn{4}{|c|}{ Notícia n으 25} \\
\hline Dia: 26 & Página: 21 & Caderno: Cidades & Possui Fotos: Sim \\
\hline \multicolumn{4}{|c|}{ Título: Na chuva, sem ônibus nem escola } \\
\hline \multicolumn{4}{|c|}{$\begin{array}{l}\text { Informações adicionais: Alunos enfrentam dificuldades para a ir à escola durante o } \\
\text { período chuvoso no Lago Oeste devido aos constantes alagamentos e a falta de } \\
\text { abrigos nas paradas de ônibus. De acordo com o DFTrans, dos } 3387 \text { pontos de ônibus } \\
\text { do DF, } 1272 \text { não possuem abrigo. }\end{array}$} \\
\hline \multicolumn{4}{|c|}{ Desastre(s) Natural(is) associado(s) à reportagem: Alagamento. } \\
\hline \multicolumn{4}{|c|}{ Região(ões) Administrativa(s) afetada(s): Planaltina (RA VI), Sobradinho (RA V). } \\
\hline \multicolumn{4}{|c|}{$\begin{array}{l}\text { Referência bibliográfica: LIBRELON, Rachel. Na chuva, sem ônibus nem escola. } \\
\text { Correio Braziliense, Brasília, } 26 \text { de out. de } 2006 \text {. Cidades, p. } 21 \text {. }\end{array}$} \\
\hline
\end{tabular}

\begin{tabular}{|c|c|c|c|}
\hline \multicolumn{3}{|c|}{ Notícia no 26} \\
\hline Dia: 27 & Página: 25 & Caderno: Cidades & Possui Fotos: Sim \\
\hline Título: Águas de outubro & \multicolumn{3}{|c|}{. } \\
\hline $\begin{array}{l}\text { Informações adicionais: Há 43 anos não chovia tanto no mês de outubro na capital. } \\
\text { Em outubro de 2005, o INMET registrou } 57 \mathrm{~mm} \text {, mas até o dia } 26 \text { de outubro de } 2006 \\
\text { já havia chovido 439 mm, dois milímetros a mais que os registrados no ano recorde } \\
\text { até então (outubro de 1981). A água alagou garagens na 402 Norte e provocou } \\
\text { engarrafamentos em diversos pontos da cidade. Na Vila Matadouro, no Riacho Fundo, } \\
72 \text { famílias foram desalojadas pela Defesa Civil. Residências no Itapoã e Planaltina } \\
\text { foram tomadas pela água. Apesar a grande quantidade de água precipitada, }\end{array}$ \\
\hline
\end{tabular}


pesquisadores do INMET e UnB acreditam que o volume de chuva é normal, já que registros semelhantes foram coletados na capital no passado em outros meses do ano. A umidade vinda da Amazônia, associada a linhas de instabilidade que vêm das frentes frias que estão sobre o Sudeste e Nordeste provocam as fortes chuvas.

Desastre(s) Natural(is) associado(s) à reportagem: Alagamento.

Região(ões) Administrativa(s) afetada(s): Brasília (RA I), Itapoã (RA XXVIII), Riacho Fundo (RA XVII), Planaltina (RA VI), Sobradinho (RA V).

Referência bibliográfica: LIBLELON, Rachel; REBELLO, Pablo. Águas de outubro. Correio Braziliense, Brasília, 27 de out. de 2006. Cidades, p. 25.

\begin{tabular}{|c|c|c|c|}
\hline \multicolumn{4}{|c|}{ Notícia nº 27} \\
\hline Dia: 28 & Página: 27 & Caderno: Cidades & Possui Fotos: Sim \\
\hline \multicolumn{4}{|c|}{ Título: Perto de uma marca histórica } \\
\hline \multicolumn{4}{|c|}{$\begin{array}{l}\text { Informações adicionais: O mês de outubro já é o segundo mais chuvoso da capital, } \\
\text { só perdendo para janeiro de } 1989 \text {, no qual choveu } 608 \mathrm{~mm} \text {. Na Fercal, } 208 \text { pessoas } \\
\text { foram desabrigadas. A chuva também alagou garagens e danificou equipamentos em } \\
\text { lojas nas quadras } 911 \text { e } 511 \text { Norte. Somente na última quinta o INMET registrou } 103 \\
\text { mm de chuva. }\end{array}$} \\
\hline \multicolumn{4}{|c|}{ Desastre(s) Natural(is) associado(s) à reportagem: Alagamento. } \\
\hline \multicolumn{4}{|c|}{ Região(ões) Administrativa(s) afetada(s): Brasília (RA I), Sobradinho (RA V). } \\
\hline $\begin{array}{l}\text { Referênc } \\
\text { Braziliens }\end{array}$ & $\begin{array}{l}\text { liográfica: } \\
\text { sília, } 28 \text { de }\end{array}$ & $\begin{array}{l}\text { ON, Rachel. Perto } \\
\text { 2006. Cidades, p. }\end{array}$ & ca histórica. Corı \\
\hline
\end{tabular}

\begin{tabular}{|c|c|c|c|}
\hline \multicolumn{3}{|c|}{ Notícia no 28} \\
\hline Dia: 28 & Página: 28 & Caderno: Cidades & Possui Fotos: Sim \\
\hline Título: Chuva entope a capital \\
\hline $\begin{array}{l}\text { Informações adicionais: Impermeabilização e ocupação do solo, bocas de lobo } \\
\text { obstruídas e volume recorde de chuvas alagam diversos pontos do Plano Piloto. } \\
\text { NOVACAP diz que faz limpeza constantes nos bueiros durante o ano e que as } \\
\text { tesourinhas são exemplos de bom funcionamento das bocas de lobo, pois assim que a } \\
\text { chuva acaba a água é escoada. }\end{array}$ \\
\hline Desastre(s) Natural(is) associado(s) à reportagem: Alagamentos \\
\hline Região(ões) Administrativa(s) afetada(s): Brasília (RA I). \\
\hline
\end{tabular}


Referência bibliográfica: LIBRELON, Rachel. Chuva entope a capital. Correio Braziliense, Brasília, 28 de out. de 2006. Cidades, p. 28.

\begin{tabular}{|c|c|c|c|}
\hline \multicolumn{3}{|c|}{ Notícia no 29} \\
\hline Dia: 28 & Página: 28 & \multicolumn{1}{|c|}{ Caderno: Cidades } & Possui Fotos: Sim \\
\hline Título: Nível do Paranoá no limite \\
\hline $\begin{array}{l}\text { Informações adicionais: Devido o excesso de chuvas, a CEB irá abrir as comportas } \\
\text { do Lago Paranoá para evitar inundações. Na Fercal, enxurrada chegou a } 20 \mathrm{~cm} \text { e } \\
\text { Córrego do Engenho Velho transbordou. No Varjão, enxurrada invadiu e alagou } \\
\text { apartamentos do andar térreo do Projeto Habitar Brasil, financiado pelo Banco } \\
\text { Interamericano de Desenvolvimento (BID). }\end{array}$ \\
\hline Desastre(s) Natural(is) associado(s) à reportagem: Alagamento, enxurrada. \\
\hline $\begin{array}{l}\text { Região(ões) Administrativa(s) afetada(s): Brasília (RA I), Fercal (RA XXXI), Varjão } \\
\text { (RA XXIII). }\end{array}$ \\
\hline $\begin{array}{l}\text { Referência bibliográfica: LIBRELON, Rachel. Chuva entope a capital. Correio } \\
\text { Braziliense, Brasília, 28 de out. de 2006. Cidades, p. 28. }\end{array}$ \\
\hline
\end{tabular}

\begin{tabular}{|c|c|c|c|}
\hline \multicolumn{4}{|c|}{ Notícia n 30} \\
\hline Dia: 28 & Página: 29 & Caderno: Cidades & Possui Fotos: Sim \\
\hline \multicolumn{4}{|c|}{ Título: Obras paradas há dois meses } \\
\hline \multicolumn{4}{|c|}{$\begin{array}{l}\text { Informações adicionais: As três maiores obras viárias do DF, em Vicente Pires } \\
\text { (duplicação da Marginal Sul da Estrutural), Paranoá (duplicação da DF-005) e } \\
\text { Planaltina (duplicação da DF-130) estão paradas devido às fortes chuvas que caem no } \\
\text { mês de outubro. A paralisação das obras além de causar o aumento do custo das } \\
\text { obras tem provocado o surgimento de buracos, erosões e até assoreamento de } \\
\text { mananciais próximos destas. }\end{array}$} \\
\hline \multicolumn{4}{|c|}{ Desastre(s) Natural(is) associado(s) à reportagem: Erosão. } \\
\hline \multicolumn{4}{|c|}{$\begin{array}{l}\text { Região(ões) Administrativa(s) afetada(s): Planaltina (RA VI), Taguatinga (RA III), } \\
\text { Varjão (RA XXIII). }\end{array}$} \\
\hline \multicolumn{4}{|c|}{$\begin{array}{l}\text { Referência bibliográfica: ALVES, Renato. Obras paradas há dois meses. Correio } \\
\text { Braziliense, Brasília, } 28 \text { de out. de } 2006 \text {. Cidades, p. } 29 \text {. }\end{array}$} \\
\hline
\end{tabular}

\section{Notícia no 31}




\begin{tabular}{|c|c|c|c|}
\hline Dia: 28 & Página: 30 & Caderno: Cidades & Possui Fotos: Sim \\
\hline \multicolumn{4}{|c|}{ Título: Ziguezague para escapar de buracos } \\
\hline \multicolumn{4}{|c|}{$\begin{array}{l}\text { Informações adicionais: As obras de duplicação da DF-130 deixa o solo exposto às } \\
\text { fortes chuvas e dificulta a vida de cerca de } 30 \text { mil pessoas que trafegam pela via todos } \\
\text { os dias. DER, responsável pela obra, diz que ela será retomada após o fim do período } \\
\text { chuvoso. }\end{array}$} \\
\hline \multicolumn{4}{|c|}{ Desastre(s) Natural(is) associado(s) à reportagem: Erosão. } \\
\hline \multicolumn{4}{|c|}{ Região(ões) Administrativa(s) afetada(s): Planaltina (RA VI). } \\
\hline \multicolumn{4}{|c|}{$\begin{array}{l}\text { Referência bibliográfica: ALVES, Renato. Ziguezague para escapar de buracos. } \\
\text { Correio Braziliense, Brasília, } 28 \text { de out. de } 2006 \text {. Cidades, p. } 30 .\end{array}$} \\
\hline
\end{tabular}

\begin{tabular}{|c|c|c|c|}
\hline \multicolumn{3}{|c|}{ Notícia no 32} \\
\hline Dia: 28 & Página: 30 & \multicolumn{1}{|c|}{ Caderno: Cidades } & Possui Fotos: Sim \\
\hline Título: Prejuízo em Vicente Pires \\
\hline $\begin{array}{l}\text { Informações adicionais: DER interrompe as obras de duplicação da DF-005 em } \\
\text { Vicente Pires devido à falta de recursos para continuar a obra. Enquanto o dinheiro } \\
\text { não é repassado, enxurradas invadem casas e formam lamaçais na região. }\end{array}$ \\
\hline Desastre(s) Natural(is) associado(s) à reportagem: Enxurrada. \\
\hline Região(ões) Administrativa(s) afetada(s): Vicente Pires (RA XXX). \\
\hline $\begin{array}{l}\text { Referência bibliográfica: ALVES, Renato. Prejuízo em Vicente Pires. Correio } \\
\text { Braziliense, Brasília, 28 de out. de 2006. Cidades, p. 30. }\end{array}$ \\
\hline
\end{tabular}

\section{Novembro}

\begin{tabular}{|c|c|c|c|}
\hline \multicolumn{4}{|c|}{ Notícia nํ 33} \\
\hline Dia: 07 & Página: 28 & Caderno: Cidades & Possui Fotos: Sim \\
\hline \multicolumn{4}{|c|}{ Título: Alagados e esquecidos de Itapoã } \\
\hline \multicolumn{4}{|c|}{$\begin{array}{l}\text { Informações adicionais: Em Itapoã, chuvas causam enxurradas e alagamentos } \\
\text { constantes. Rede de águas pluviais já foi licitada, mas ainda não foi implantada. } \\
\text { Chuvas de outubro pioraram a situação da área, eram esperados } 170 \mathrm{~mm} \text { de chuva, } \\
\text { mas foram registrados mais de } 526 \mathrm{~mm} \text { de acordo com o INMET. Zona de } \\
\text { Convergência do Atlântico Sul deixou vários pontos do DF com uma cortina de neblina } \\
\text { pela manhã, especialmente no Plano Piloto. }\end{array}$} \\
\hline
\end{tabular}


Desastre(s) Natural(is) associado(s) à reportagem: Alagamento, enxurrada.

Região(ões) Administrativa(s) afetada(s): Brasília (RA I), Itapoã (RA XXVIII).

Referência bibliográfica: LIBRELON, Rachel. Alagados e esquecidos de Itapoã.

Correio Braziliense, Brasília, 07 de nov. de 2006. Cidades, p. 30.

\begin{tabular}{|c|c|c|c|}
\hline \multicolumn{4}{|c|}{ Notícia n우 34} \\
\hline Dia: 09 & Página: 34 & Caderno: Cidades & Possui Fotos: Sim \\
\hline \multicolumn{4}{|c|}{ Título: Prejuízo no campo e na cidade } \\
\hline \multicolumn{4}{|c|}{$\begin{array}{l}\text { Informações adicionais: São Sebastião foi a cidade mais afetada pelas últimas } \\
\text { chuvas. Água alagou casas e trouxe problemas pra os moradores do campo, como } \\
\text { erosões e queda de árvores. De acordo com o INMET, nos primeiros oito dias de } \\
\text { novembro já choveu quase metade }(109,3 \mathrm{~mm}) \text { do que é esperado para o mês ( } 238 \\
\text { mm). }\end{array}$} \\
\hline \multicolumn{4}{|c|}{$\begin{array}{l}\text { Desastre(s) Natural(is) associado(s) à reportagem: Alagamento, enxurrada, erosão, } \\
\text { vendaval. }\end{array}$} \\
\hline \multicolumn{4}{|c|}{ Região(ões) Administrativa(s) afetada(s): São Sebastião (RA XIV). } \\
\hline \multicolumn{4}{|c|}{$\begin{array}{l}\text { Referência bibliográfica: BISA, Leandro. Prejuízo no campo e na cidade. Correio } \\
\text { Braziliense, Brasília, } 09 \text { nov. de } 2006 \text {. Cidades, p. } 34 \text {. }\end{array}$} \\
\hline
\end{tabular}

\begin{tabular}{|c|c|c|c|}
\hline \multicolumn{4}{|c|}{ Notícia n 35} \\
\hline Dia: 22 & Página: 30 & Caderno: Cidades & Possui Fotos: Sim \\
\hline \multicolumn{4}{|c|}{ Título: Época de chuva e ventania } \\
\hline \multicolumn{4}{|c|}{$\begin{array}{l}\text { Informações adicionais: QE } 28 \text { do Guará tem queda de árvore durante forte temporal } \\
\text { com ventanias. No Lago Sul, chove granizo. }\end{array}$} \\
\hline \multicolumn{4}{|c|}{$\begin{array}{l}\text { Desastre(s) Natural(is) associado(s) à reportagem: Alagamentos, granizo, } \\
\text { vendaval. }\end{array}$} \\
\hline \multicolumn{4}{|c|}{ Região(ões) Administrativa(s) afetada(s): Guará (RA X), Lago Sul (RA XVI) } \\
\hline \multicolumn{4}{|c|}{$\begin{array}{l}\text { Referência bibliográfica: GOULART, Guilherme. Época de chuva e ventania. Correio } \\
\text { Braziliense, Brasília, } 22 \text { nov. de 2006. Cidades, p. } 30 \text {. }\end{array}$} \\
\hline
\end{tabular}

\section{Dezembro}




\begin{tabular}{|c|c|c|c|}
\hline \multicolumn{4}{|c|}{ Notícia n 36} \\
\hline Dia: 13 & Página: 25 & Caderno: Cidades & Possui Fotos: Sim \\
\hline \multicolumn{4}{|c|}{ Título: Piscinão na Rodoviária de Brasília } \\
\hline \multicolumn{4}{|c|}{$\begin{array}{l}\text { Informações adicionais: Chuva alagou obra no estacionamento da plataforma } \\
\text { superior da Rodoviária do Plano Piloto e provocou engarrafamentos em diversos } \\
\text { pontos da cidade, especialmente na via Estrutural. Secretário de Obras diz que } \\
\text { alagamento de obra na rodoviária serve para verificação da vedação dos } \\
\text { estacionamentos. Usuários da rodoviária reclamam das constantes goteiras e da falta } \\
\text { de preparo da estrutura para o período chuvoso. Depois de } 24 \mathrm{~h} \text { de chuvas } \\
\text { ininterruptas, INMET registra } 71 \mathrm{~mm} \text { de precipitação. Até o dia } 12 \text { de dezembro já } \\
\text { choveu } 111 \mathrm{~mm} \text {, quase metade do esperado para o mês cuja média é } 248,6 \mathrm{~mm} \text {. } \\
\text { Chuvas foram causadas pelo encontro de uma frente fria semiestacionária que estava } \\
\text { sobre Minas Gerais e o Rio de Janeiro com uma massa de ar quente do Oceano } \\
\text { Atlântico, de acordo com o órgão. }\end{array}$} \\
\hline \multicolumn{4}{|c|}{ Desastre(s) Natural(is) associado(s) à reportagem: Alagamento. } \\
\hline \multicolumn{4}{|c|}{$\begin{array}{l}\text { Região(ões) Administrativa(s) afetada(s): Brasília (RA I), Setor Complementar de } \\
\text { Indústria e Abastecimento (RA XXV). }\end{array}$} \\
\hline \multicolumn{4}{|c|}{$\begin{array}{l}\text { Referência bibliográfica: REBELLO, Pablo. Piscinão na Rodoviária de Brasília. } \\
\text { Correio Braziliense, Brasília, } 13 \text { dez. de 2006. Cidades, p. } 25 \text {. }\end{array}$} \\
\hline
\end{tabular}

\section{APÊNDICE VIII}
Desastres Naturais relacionados às chuvas no Distrito Federal relatados no jornal Correio Braziliense no ano de 2007

Janeiro 


\begin{tabular}{|c|c|c|c|}
\hline \multicolumn{4}{|c|}{ Notícia no 1} \\
\hline Dia: 03 & Página: 26 & Caderno: Cidades & Possui Fotos: Sim \\
\hline \multicolumn{4}{|c|}{ Título: Estragos que vem com a chuva } \\
\hline \multicolumn{4}{|c|}{$\begin{array}{l}\text { Informações adicionais: A ausência de galerias pluviais deixa quadra } 802 \text { no } \\
\text { Recanto das Emas alagada. No Lago Norte, a chuva abriu um buraco tão grande na } \\
\text { pista que morador plantou uma bananeira dentro. No Núcleo Bandeirante, moradores } \\
\text { da Vila Cauhy sofrem com as enxurradas. INMET afirma que as fortes chuvas são } \\
\text { resultado da atuação da Zona de Convergência do Atlântico Sul nos últimos dias. }\end{array}$} \\
\hline \multicolumn{4}{|c|}{ Desastre(s) Natural(is) associado(s) à reportagem: Alagamento, enxurrada. } \\
\hline \multicolumn{4}{|c|}{$\begin{array}{l}\text { Região(ões) Administrativa(s) afetada(s): Núcleo Bandeirante (RA VIII), Recanto } \\
\text { das Emas (RA XV). }\end{array}$} \\
\hline \multicolumn{4}{|c|}{$\begin{array}{l}\text { Referência bibliográfica: BERNARDES, Adriana; GÓIS, Fabiana. Estragos que vem } \\
\text { com a chuva. Correio Braziliense, Brasília, } 03 \text { de jan. de 2007. Cidades, p. } 26 \text {. }\end{array}$} \\
\hline
\end{tabular}

\begin{tabular}{|c|c|c|c|}
\hline \multicolumn{4}{|c|}{ Notícia no 2} \\
\hline Dia: 28 & Página: 30 & Caderno: Cidades & Possui Fotos: Sim \\
\hline \multicolumn{4}{|c|}{ Título: Trânsito confuso e susto no Colorado } \\
\hline \multicolumn{4}{|c|}{$\begin{array}{l}\text { Informações adicionais: Chuva causou oito acidentes até o início da tarde em vários } \\
\text { pontos do DF. O mais grave ocorreu no Colorado onde três carros derraparam, dois } \\
\text { caminhões e um ônibus derraparam no mesmo local. O trânsito teve que ser desviado } \\
\text { para o Paranoá. O Corpo de Bombeiros também registrou alagamentos em Ceilândia } \\
\text { e Taguatinga. }\end{array}$} \\
\hline \multicolumn{4}{|c|}{ Desastre(s) Natural(is) associado(s) à reportagem: Alagamento. } \\
\hline \multicolumn{4}{|c|}{ Região(ões) Administrativa(s) afetada(s): Ceilândia (RA IX), Taguatinga (RA III). } \\
\hline \multicolumn{4}{|c|}{$\begin{array}{l}\text { Referência bibliográfica: REDAÇÃO. Trânsito confuso e susto no Colorado. Correio } \\
\text { Braziliense, Brasília, } 28 \text { de jan. de } 2007 \text {. Cidades, p. } 30 \text {. }\end{array}$} \\
\hline
\end{tabular}

\section{Fevereiro}

\begin{tabular}{|c|c|c|c|}
\hline \multicolumn{3}{|c|}{ Notícia n 3 $^{\text {3 }}$} \\
\hline Dia: 09 & Página: 28 & Caderno: Cidades & Possui Fotos: Não \\
\hline
\end{tabular}


Título: Casas sob risco de desabar

Informações adicionais: Enxurradas das chuvas formam pequeno riacho no Condomínio Sol Nascente e casas correm risco de desabar. A Defesa Civil interditou várias casas na área.

Desastre(s) Natural(is) associado(s) à reportagem: Enxurrada

Região(ões) Administrativa(s) afetada(s): Ceilândia (RA IX).

Referência bibliográfica: REDAÇÃO. Casas sob risco de desabar. Correio

Braziliense, Brasília, 9 de fev. de 2007. Cidades, p. 28.

\begin{tabular}{|c|c|c|c|}
\hline \multicolumn{4}{|c|}{ Notícia $n \div 4$} \\
\hline Dia: 18 & Página: 30 & Caderno: Cidades & Possui Fotos: Sim \\
\hline \multicolumn{4}{|c|}{ Título: Temporal alaga ruas no Plano Piloto } \\
\hline \multicolumn{4}{|c|}{$\begin{array}{l}\text { Informações adicionais: Chuva provocou alagamentos em diversos pontos da } \\
\text { cidade. W3 Norte, L2 Norte e L4 Sul foram as vias mais afetadas. }\end{array}$} \\
\hline \multicolumn{4}{|c|}{ Desastre(s) Natural(is) associado(s) à reportagem: Alagamento. } \\
\hline \multicolumn{4}{|c|}{ Região(ões) Administrativa(s) afetada(s): Brasília (RA I). } \\
\hline $\begin{array}{l}\text { Referênci } \\
\text { Braziliens }\end{array}$ & $\begin{array}{l}\text { liográfica: } \\
\text { asília, } 18 \text { de }\end{array}$ & $\begin{array}{l}\text { 200. Temporal alage } \\
\text { 2007. Cidades, p. } 3\end{array}$ & Plano Piloto. Correio \\
\hline
\end{tabular}

\begin{tabular}{|c|c|c|c|}
\hline \multicolumn{4}{|c|}{ Notícia nํ 5} \\
\hline Dia: 19 & Página: 27 & Caderno: Cidades & Possui Fotos: Sim \\
\hline \multicolumn{4}{|c|}{ Título: Esgoto transborda e alaga setor de hospital } \\
\hline \multicolumn{4}{|c|}{$\begin{array}{l}\text { Informações adicionais: No setor P Sul, no Condomínio Sonho Verde, mais de } 50 \\
\text { famílias tiveram casas alagadas e perderam eletrodomésticos e outros bens. No } \\
\text { Hospital de Ceilândia, o esgoto transbordou no setor de Emergência Pediátrica. Na } \\
\text { Guariroba, também em Ceilândia, enxurrada chegou a arrastar três carros. INMET } \\
\text { disse que chuvas na Ceilândia foram provocadas por pancadas isoladas, por isso não } \\
\text { há como medir pois não há equipamentos na região. }\end{array}$} \\
\hline \multicolumn{4}{|c|}{ Desastre(s) Natural(is) associado(s) à reportagem: Alagamento, enxurrada. } \\
\hline \multicolumn{4}{|c|}{ Região(ões) Administrativa(s) afetada(s): Ceilândia (RA IX). } \\
\hline
\end{tabular}


hospital. Correio Braziliense, Brasília, 19 de fev. de 2007. Cidades, p. 27.

\section{Notícia no 6}

\begin{tabular}{l|l|l|l} 
Dia: 20 & Página: 24 & Caderno: Cidades & Possui Fotos: Sim
\end{tabular}

Título: Acúmulo de chuvas e problemas

Informações adicionais: Chuva alaga 56 residências no Condomínio Sonho Verde, na expansão do setor $P$ Sul, na Ceilândia. Famílias foram transferidas para albergues. Houve grandes perdas materiais.

Desastre(s) Natural(is) associado(s) à reportagem: Alagamento.

Região(ões) Administrativa(s) afetada(s): Ceilândia (RA IX).

Referência bibliográfica: RODRIGUES, Gizela. Acúmulo de chuvas e problemas. Correio Braziliense, Brasília, 20 de fev. de 2007. Cidades, p. 24.

\begin{tabular}{|c|c|c|c|}
\hline \multicolumn{4}{|c|}{ Notícia nำ 7} \\
\hline Dia: 24 & Página: 29 & Caderno: Cidades & Possui Fotos: Sim \\
\hline \multicolumn{4}{|c|}{ Título: Sem distinção de classe social } \\
\hline \multicolumn{4}{|c|}{$\begin{array}{l}\text { Informações adicionais: Estudo do Laboratório de Climatologia Geográfica da } \\
\text { Universidade de Brasília mostra que os alagamentos no Plano Piloto são resultado das } \\
\text { mudanças urbanísticas nas áreas centrais da cidade nos últimos anos, como } \\
\text { ocupação das quadras } 700 / 900 \text {. Os alagamentos se concentram quadras que } \\
\text { começam com números pares porque estão topograficamente mais baixas. A } \\
\text { impermeabilização do solo é um fator preponderante. }\end{array}$} \\
\hline \multicolumn{4}{|c|}{ Desastre(s) Natural(is) associado(s) à reportagem: Alagamento. } \\
\hline \multicolumn{4}{|c|}{ Região(ões) Administrativa(s) afetada(s): Brasília (RA I). } \\
\hline $\begin{array}{l}\text { Referênci } \\
\text { Correio } B \prime\end{array}$ & $\begin{array}{l}\text { bliográfica: } \Lambda \\
\text { iense, Brasília }\end{array}$ & $\begin{array}{l}\text { ENEGRO, Érica. Ser } \\
\text { e fev. de 2007. Cidad }\end{array}$ & to de classe social. \\
\hline
\end{tabular}

\section{Março}

\section{Notícia no 8}




\begin{tabular}{|c|c|c|c|}
\hline Dia: 17 & Página: 34 & Caderno: Cidades & Possui Fotos: Sim \\
\hline \multicolumn{4}{|c|}{ Título: Temporal leva caos a brasiliense } \\
\hline \multicolumn{4}{|c|}{$\begin{array}{l}\text { Informações adicionais: As quadras } 107,108,311,509,510,511,512 \text { e } 710 \text { Norte } \\
\text { foram varridas pela enxurrada após forte chuva, que alagou muitas lojas e ainda } \\
\text { escorreu e desceu para alagar também a tesourinha da } 209 \text { Norte. Engarrafamentos } \\
\text { tumultuaram o trânsito por duas horas. Especialistas acreditam que o sistema de } \\
\text { vazão das águas da chuva foi planejado há } 20 \text { anos atrás e não levou em } \\
\text { consideração o rápido crescimento da cidade, acompanhado de grande adensamento } \\
\text { populacional. Chuva também causou engarrafamentos em Águas Claras e Taguatinga. }\end{array}$} \\
\hline \multicolumn{4}{|c|}{ Desastre(s) Natural(is) associado(s) à reportagem: Alagamento, enxurrada. } \\
\hline \multicolumn{4}{|c|}{ Região(ões) Administrativa(s) afetada(s): Brasília (RA I). } \\
\hline \multicolumn{4}{|c|}{$\begin{array}{l}\text { Referência bibliográfica: BEZERRA, André. Temporal leva caos a brasiliense. } \\
\text { Correio Braziliense, Brasília, } 17 \text { de mar. de 2007. Cidades, p. } 34 \text {. }\end{array}$} \\
\hline
\end{tabular}

\begin{tabular}{|c|c|c|c|}
\hline \multicolumn{4}{|c|}{ Notícia nㅇ 9} \\
\hline Dia: 17 & Página: 34 & Caderno: Cidades & Possui Fotos: Não \\
\hline \multicolumn{4}{|c|}{ Título: INMET prevê mau tempo } \\
\hline \multicolumn{4}{|c|}{$\begin{array}{l}\text { Informações adicionais: Chuva causou enxurradas na Asa Norte, Guará e Núcleo } \\
\text { Bandeirante. Em } 40 \text { minutos, o INMET registrou } 18 \mathrm{~mm} \text { de chuva, o que mostra sua } \\
\text { intensidade. De acordo com os meteorologistas as chuvas fortes são comuns no fim } \\
\text { de verão, em que ocorrem de forma mais rápida e intensa. Uma pequena estação do } \\
\text { INMET de previsão do tempo no Recanto das Emas registrou } 68 \mathrm{~mm} \text { de pluviosidade. } \\
\text { Apesar disso, não houve problemas significativos com os cidadãos da região sudoeste } \\
\text { do DF. }\end{array}$} \\
\hline \multicolumn{4}{|c|}{ Desastre(s) Natural(is) associado(s) à reportagem: Enxurrada. } \\
\hline \multicolumn{4}{|c|}{$\begin{array}{l}\text { Região(ões) Administrativa(s) afetada(s): Brasília (RA I), Guará (RA II), Núcleo } \\
\text { Bandeirante (VIII). }\end{array}$} \\
\hline \multicolumn{4}{|c|}{$\begin{array}{l}\text { Referência bibliográfica: BEZERRA, André. INMET prevê mau tempo. Correio } \\
\text { Braziliense, Brasília, } 17 \text { de mar. de } 2007 \text {. Cidades, p. } 34 \text {. }\end{array}$} \\
\hline
\end{tabular}

\begin{tabular}{|c|c|c|c|}
\hline \multicolumn{3}{|c|}{ Notícia no 10 } \\
\hline Dia: 18 & Página: 29 & Caderno: Cidades & Possui Fotos: Sim \\
\hline
\end{tabular}


Título: Dia de calcular prejuízo

Informações adicionais: Após os alagamentos do dia 16, ontem foi dia de calcular os prejuízos. Em loja na 511, prejuízo chegou a 500 mil reais. O secretário de Obras do DF afirma que a rede de águas pluviais está saturada devido à impermeabilização do solo e que a NOVACAP faz a manutenção da rede periodicamente.

Desastre(s) Natural(is) associado(s) à reportagem: Alagamento.

Região(ões) Administrativa(s) afetada(s): Brasília (RA I).

Referência bibliográfica: CASTRO, Jorge de. Dia de calcular prejuízo. Correio Braziliense, Brasília, 18 de mar. de 2007. Cidades, p. 29.

\begin{tabular}{|c|c|c|c|}
\hline \multicolumn{4}{|c|}{ Notícia nำ11 } \\
\hline Dia: 22 & Página: 28 & Caderno: Cidades & Possui Fotos: Sim \\
\hline \multicolumn{4}{|c|}{ Título: Temporal e lixo entopem Asa Norte } \\
\hline \multicolumn{4}{|c|}{$\begin{array}{l}\text { Informações adicionais: A tempestade que desabou sobre a Asa Norte na última } \\
\text { sexta-feira expôs uma fragilidade que deixou de ser exclusiva das áreas mais carentes } \\
\text { do Distrito Federal. Antes restritos a regiões sem infraestrutura, os alagamentos } \\
\text { chegaram ao Plano Piloto e foram responsáveis por prejuízos ainda incalculáveis. }\end{array}$} \\
\hline \multicolumn{4}{|c|}{ Desastre(s) Natural(is) associado(s) à reportagem: Alagamento. } \\
\hline \multicolumn{4}{|c|}{ Região(ões) Administrativa(s) afetada(s): Brasília (RA I). } \\
\hline
\end{tabular}

\begin{tabular}{|c|c|c|c|}
\hline \multicolumn{4}{|c|}{ Notícia no 12} \\
\hline Dia: 22 & Página: 28 & Caderno: Cidades & Possui Fotos: Não \\
\hline \multicolumn{4}{|c|}{ Título: Prejuízos financeiros } \\
\hline \multicolumn{4}{|c|}{$\begin{array}{l}\text { Informações adicionais: Após a chuva do dia 17, empresários ainda tentavam limpar } \\
\text { as lojas e recuperar o maior número de mercadorias que não foram danificadas. }\end{array}$} \\
\hline \multicolumn{4}{|c|}{ Desastre(s) Natural(is) associado(s) à reportagem: Alagamento. } \\
\hline \multicolumn{4}{|c|}{ Região(ões) Administrativa(s) afetada(s): Brasília (RA I). } \\
\hline \multicolumn{4}{|c|}{$\begin{array}{l}\text { Referência bibliográfica: RODRIGUES, Gizella. Prejuízos financeiros. Correio } \\
\text { Braziliense, Brasília, } 22 \text { de mar. de 2007. Cidades, p. } 28 .\end{array}$} \\
\hline
\end{tabular}




\begin{tabular}{|c|c|c|c|}
\hline \multicolumn{4}{|c|}{ Notícia nำ 13} \\
\hline Dia: 22 & Página: 33 & Caderno: Cidades & Possui Fotos: Sim \\
\hline \multicolumn{4}{|c|}{ Título: Alerta contra enxurradas } \\
\hline \multicolumn{4}{|c|}{$\begin{array}{l}\text { Informações adicionais: Mulher foi arrastada por } 40 \text { metros na chuva por enxurrada } \\
\text { na Asa Norte, próximo ao Hospital Regional da Asa Norte. INMET diz que chuvas } \\
\text { rápidas e intensas são previstas para o mês. }\end{array}$} \\
\hline \multicolumn{4}{|c|}{ Desastre(s) Natural(is) associado(s) à reportagem: Enxurrada. } \\
\hline \multicolumn{4}{|c|}{ Região(ões) Administrativa(s) afetada(s): Brasília (RA I). } \\
\hline \multicolumn{4}{|c|}{$\begin{array}{l}\text { Referência bibliográfica: REDAÇÃO. Alerta contra enxurradas. Correio Braziliense, } \\
\text { Brasília, } 22 \text { de mar. de } 2007 \text {. Cidades, p. } 33 .\end{array}$} \\
\hline
\end{tabular}

\section{Outubro}

\begin{tabular}{|c|c|c|c|}
\hline \multicolumn{4}{|c|}{ Notícia nํ 14} \\
\hline Dia: 20 & Página: 38 & Caderno: Cidades & Possui Fotos: Sim \\
\hline \multicolumn{4}{|c|}{ Título: Previsão de chuvas e trovoadas } \\
\hline \multicolumn{4}{|c|}{$\begin{array}{l}\text { Informações adicionais: Chove granizo em Brazlândia e São Sebastião na noite de } \\
\text { ontem. }\end{array}$} \\
\hline \multicolumn{4}{|c|}{ Desastre(s) Natural(is) associado(s) à reportagem: Granizo. } \\
\hline \multicolumn{4}{|c|}{$\begin{array}{l}\text { Região(ões) Administrativa(s) afetada(s): Brazlândia (RA IV) e São Sebastião (RA } \\
\text { XIV). }\end{array}$} \\
\hline \multicolumn{4}{|c|}{$\begin{array}{l}\text { Referência bibliográfica: REDAÇÃO. Previsão de chuvas e trovoadas. Correio } \\
\text { Braziliense, Brasília, } 3 \text { de out. de 2007. Cidades, p. } 26 \text {. }\end{array}$} \\
\hline
\end{tabular}

\begin{tabular}{|c|c|c|c|}
\hline \multicolumn{4}{|c|}{ Notícia nํ 15} \\
\hline Dia: 23 & Página: 23 & Caderno: Cidades & Possui Fotos: Sim \\
\hline \multicolumn{4}{|c|}{ Título: Chuvas alagam e param trânsito } \\
\hline \multicolumn{4}{|c|}{$\begin{array}{l}\text { Informações adicionais: Chuva causou diversos alagamentos e engarrafamentos na } \\
\text { cidade. Na entrada da Estrutural, ônibus quebra no acesso da cidade e cria } \\
\text { engarrafamento na via de mesmo nome. Segundo o INMET, o período chuvoso já }\end{array}$} \\
\hline
\end{tabular}


começou. A Defesa Civil emitiu alertas para as áreas vulneráveis do DF devido às fortes chuvas.

Desastre(s) Natural(is) associado(s) à reportagem: Alagamento.

Região(ões) Administrativa(s) afetada(s): Águas Claras (RA XX), Brasília (RA I), Guará (RA X), Setor de Indústria e Abastecimento (RA XXIX), Setor Complementar de Indústria e Abastecimento (RA XXV) e Taguatinga (RA III).

Referência bibliográfica: MORAIS, Afonso; COELHO, Mário. Chuvas alagam e param trânsito. Correio Braziliense, Brasília, 23 de out. de 2007. Cidades, p. 23.

Novembro

\begin{tabular}{|c|c|c|c|}
\hline \multicolumn{4}{|c|}{ Notícia nำ 16} \\
\hline Dia: 03 & Página: 21 & Caderno: Cidades & Possui Fotos: Sim \\
\hline \multicolumn{4}{|c|}{ Título: E o tempo fechou... } \\
\hline \multicolumn{4}{|c|}{$\begin{array}{l}\text { Informações adicionais: Dois temporais no dia de finados causaram acidentes de } \\
\text { trânsito, alagamento de tesourinhas, como a da } 203 / 204 \text { Sul, queda de árvores e } \\
\text { desmoronamentos em um prédio da Asa Sul deram trabalho ao Corpo de Bombeiros, } \\
\text { que atenderam } 40 \text { ocorrências simultâneas. O primeiro começou às } 13 \text { h30 e deu uma } \\
\text { trégua pouco depois, mas a chuva voltou com força às } 17 \mathrm{~h} 30 \text {. Três árvores caíram na } \\
\text { W3 Sul. O INMET registrou }\end{array}$} \\
\hline \multicolumn{4}{|c|}{$\begin{array}{l}39 \mathrm{~mm} \text { de precipitação e a média dos meses de novembro é de } 238 \mathrm{~mm} \text {. O órgão alerta } \\
\text { para a temporada de chuvas que se iniciou. }\end{array}$} \\
\hline \multicolumn{4}{|c|}{ Desastre(s) Natural(is) associado(s) à reportagem: Alagamento, vendaval. } \\
\hline \multicolumn{4}{|c|}{ Região(ões) Administrativa(s) afetada(s): Brasília (RA I). } \\
\hline \multicolumn{4}{|c|}{$\begin{array}{l}\text { Referência bibliográfica: GÓES, Dalila; LANSKY, Daniel; MADER, Helena. E o } \\
\text { tempo fechou. Correio Braziliense, Brasília, } 3 \text { de nov. de 2007. Cidades, p. } 21 .\end{array}$} \\
\hline
\end{tabular}

\begin{tabular}{|c|c|c|c|}
\hline \multicolumn{4}{|c|}{ Notícia nำ 17} \\
\hline Dia: 03 & Página: 22 & Caderno: Cidades & Possui Fotos: Sim \\
\hline \multicolumn{4}{|c|}{ Título: Quatro horas que valem por um mês } \\
\hline \multicolumn{4}{|c|}{$\begin{array}{l}\text { Informações adicionais: No Dia de Finados, o INMET registrou } 39 \mathrm{~mm} \text { de chuva, } \\
\text { índice quase } 40 \% \text { superior aos } 28 \mathrm{~mm} \text { que choveram em todo o mês de outubro. } \\
\text { Chuva forte causou blecaute que deixou o Cruzeiro sem luz e ventania provocou }\end{array}$} \\
\hline
\end{tabular}


queda de árvores na 705, 708 e 709 Sul e deixaram um carro danificado. Na 410 Sul a parede de um apartamento desmoronou devido ao entupimento de um cano de escoamento de água. No Setor Hoteleiro, o piso de um estacionamento cedeu e em Sobradinho vento derrubou dois outdoors.

Desastre(s) Natural(is) associado(s) à reportagem: Vendaval

Região(ões) Administrativa(s) afetada(s): Brasília (RA I), Cruzeiro (RA XI), Sobradinho (RA V).

Referência bibliográfica: MADER, Helena; LANSKY, Daniel; FILGUEIRA, Ary. Quatro horas que valem por um mês. Correio Braziliense, Brasília, 3 de nov. de 2007. Cidades, p. 22.

\begin{tabular}{|c|c|c|c|}
\hline \multicolumn{4}{|c|}{ Notícia n 18} \\
\hline Dia: 04 & Página: 29 & Caderno: Cidades & Possui Fotos: Sim \\
\hline \multicolumn{4}{|c|}{ Título: Chuvas fortes até terça-feira } \\
\hline \multicolumn{4}{|c|}{$\begin{array}{l}\text { Informações adicionais: Chuvas fortes do dia } 3 \text { destelharam casas na Fercal. Vários } \\
\text { moradores estão em áreas de risco. }\end{array}$} \\
\hline \multicolumn{4}{|c|}{ Desastre(s) Natural(is) associado(s) à reportagem: Vendaval. } \\
\hline \multicolumn{4}{|c|}{ Região(ões) Administrativa(s) afetada(s): Fercal (RA XXXI). } \\
\hline $\begin{array}{l}\text { Referênc } \\
\text { Braziliens }\end{array}$ & $\begin{array}{l}\text { bliográfica: } 1 \\
\text { asília, } 4 \text { de } \mathrm{n}\end{array}$ & $\begin{array}{l}\text { R, Helena. Chuvas fo } \\
\text { 2007. Cidades, p. } 29\end{array}$ & terça-feira. Correio \\
\hline
\end{tabular}

\begin{tabular}{|c|c|c|c|}
\hline \multicolumn{4}{|c|}{ Notícia nำ 19} \\
\hline Dia: 05 & Página: 17 & Caderno: Cidades & Possui Fotos: Sim \\
\hline \multicolumn{4}{|c|}{ Título: Temporal assustador } \\
\hline \multicolumn{4}{|c|}{$\begin{array}{l}\text { Informações adicionais: Com ventania causada pela chuva forte, telhas de alumínio } \\
\text { e aparelhos de ar condicionado se desprendem de teto de prédio na } 305 \text { Norte e } \\
\text { deixou } 8 \text { carros danificados. Em São Sebastião uma árvore caiu em cima de uma } \\
\text { pessoa, que está internada em estado grave. O Corpo de Bombeiros atendeu } 87 \\
\text { chamados. Os quatro primeiros dias de novembro já registraram } 57 \mathrm{~mm} \text { de } \\
\text { precipitação pelo INMET. A média histórica é de } 238 \mathrm{~mm} \text {. Chuva é provocada por } \\
\text { áreas de instabilidade geradas por uma forte frente fria que está no Sudeste, de } \\
\text { acordo com o órgão. }\end{array}$} \\
\hline \multicolumn{4}{|c|}{ Desastre(s) Natural(is) associado(s) à reportagem: Vendaval. } \\
\hline
\end{tabular}


Região(ões) Administrativa(s) afetada(s): Brasília (RA I), São Sebastião (RA XIV).

Referência bibliográfica: MADER, Helena. Temporal assustador. Correio Braziliense, Brasília, 5 de nov. de 2007. Cidades, p. 17.

\begin{tabular}{|c|c|c|c|}
\hline \multicolumn{4}{|c|}{ Notícia $\mathrm{n} \div 20$} \\
\hline Dia: 05 & Página: 18 & Caderno: Cidades & Possui Fotos: Sim \\
\hline \multicolumn{4}{|c|}{ Título: Árvores caem no Plano Piloto } \\
\hline \multicolumn{4}{|c|}{$\begin{array}{l}\text { Informações adicionais: Vento chega a } 54 \mathrm{~km} / \mathrm{h} \text { na capital na chuva de ontem. Na } \\
\text { Asa Norte as chuvas provocaram diversos problemas: na altura da 104, causou } \\
\text { engarrafamento devido ao alagamento de tesourinhas; na 106, árvore caiu na pista e } \\
\text { provocou engarrafamento na quadra; na } 402 \text {, água alagou garagem de bloco; na } 702 \text {, } \\
\text { água alagou a pista e deixou alguns veículos ilhados. Defesa Civil monitora áreas } \\
\text { vulneráveis. }\end{array}$} \\
\hline \multicolumn{4}{|c|}{ Desastre(s) Natural(is) associado(s) à reportagem: Alagamento, vendaval. } \\
\hline \multicolumn{4}{|c|}{ Região(ões) Administrativa(s) afetada(s): Brasília (RA I). } \\
\hline \multicolumn{4}{|c|}{$\begin{array}{l}\text { Referência bibliográfica: MADER, Helena. Árvores caem no Plano Piloto. Correio } \\
\text { Braziliense, Brasília, } 5 \text { de nov. de } 2007 \text {. Cidades, p. } 18 .\end{array}$} \\
\hline
\end{tabular}

\begin{tabular}{|c|c|c|c|}
\hline \multicolumn{4}{|c|}{ Notícia nำ 21} \\
\hline Dia: 06 & Página: 23 & Caderno: Cidades & Possui Fotos: Não \\
\hline \multicolumn{4}{|c|}{ Título: Os pontos críticos } \\
\hline \multicolumn{4}{|c|}{$\begin{array}{l}\text { Informações adicionais: Plano Piloto apresenta } 27 \text { áreas com maior risco de } \\
\text { alagamentos. Na Asa Norte, é comum inundar entre as quadras } 602 / 603 \text { e } 902 / 903 ; \\
610 / 611 \text { e } 910 / 911 ; 615 / 616 \text { e } 915 / 916 \text {. Na Asa Sul, entre as quadras } 610 / 611 \text { e } \\
910 / 911 ; 615 / 616 \text { e } 915 / 916 \text {. O governo pretende ampliar as redes de águas pluviais, } \\
\text { construindo três grandes galerias no Plano Piloto - da } 910 \text { até a } 610 \text { Norte, } 902 \text { até a } \\
602 \text { Norte e } 913 \text { até } 613 \text { Sul. As redes não serão feitas com os tubos usados } \\
\text { atualmente, que têm, no máximo, } 1,5 m \text { de diâmetro, mas com blocos de concreto } \\
\text { armado que podem chegar a nove metros quadrados. }\end{array}$} \\
\hline \multicolumn{4}{|c|}{ Desastre(s) Natural(is) associado(s) à reportagem: Alagamento. } \\
\hline \multicolumn{4}{|c|}{ Região(ões) Administrativa(s) afetada(s): Brasília (RA I). } \\
\hline $\begin{array}{l}\text { Referênci } \\
\text { Braziliens }\end{array}$ & $\begin{array}{l}\text { bliográfica: } \mathrm{F} \\
\text { rasília, } 6 \text { de } \mathrm{nc}\end{array}$ & $\begin{array}{l}\text { IGUES, Gizela. Os p } \\
\text { 2007. Cidades, p. } 23\end{array}$ & ticos. Correio \\
\hline
\end{tabular}




\begin{tabular}{|c|c|c|c|}
\hline \multicolumn{4}{|c|}{ Notícia nㅇ 22} \\
\hline Dia: 06 & Página: 24 & Caderno: Cidades & Possui Fotos: Sim \\
\hline \multicolumn{4}{|c|}{ Título: Risco de temporal e ventania } \\
\hline \multicolumn{4}{|c|}{$\begin{array}{l}\text { Informações adicionais: Defesa Civil e INMET alertam para temporais, que já } \\
\text { destruíram barracos na Fercal. Chuva alagou subsolo do edifício Central Brasília, no } \\
\text { Setor Bancário Norte, ameaçando documentos do Instituto do Patrimônio Histórico e } \\
\text { Artístico Nacional (IPHAN). }\end{array}$} \\
\hline \multicolumn{4}{|c|}{ Desastre(s) Natural(is) associado(s) à reportagem: Alagamento, vendaval. } \\
\hline \multicolumn{4}{|c|}{ Região(ões) Administrativa(s) afetada(s): Brasília (RA I), Fercal (RA XXXI). } \\
\hline \multicolumn{4}{|c|}{$\begin{array}{l}\text { Referência bibliográfica: MORAIS, Afonso; LANSKY, Daniel. Risco de temporal e } \\
\text { ventania. Correio Braziliense, Brasília, } 6 \text { de nov. de 2007. Cidades, p. } 24 \text {. }\end{array}$} \\
\hline
\end{tabular}

\section{Dezembro}

\begin{tabular}{|c|c|c|c|}
\hline \multicolumn{4}{|c|}{ Notícia nํ 23} \\
\hline Dia: 01 & Página: 28 & Caderno: Cidades & Possui Fotos: Sim \\
\hline \multicolumn{4}{|c|}{ Título: Chuva derruba parede no Guará } \\
\hline \multicolumn{4}{|c|}{$\begin{array}{l}\text { Informações adicionais: Durante uma hora foram registrados } 34.7 \mathrm{~mm} \text { de chuva. } \\
\text { Avenida central do Guará ficou alagada e água do alagamento derrubou parede do } \\
\text { Centro de Distribuição dos Correios. No SIA a água invadiu o Batalhão do Corpo de } \\
\text { Bombeiros deixando os soldados ilhados. }\end{array}$} \\
\hline \multicolumn{4}{|c|}{ Desastre(s) Natural(is) associado(s) à reportagem: Alagamento. } \\
\hline \multicolumn{4}{|c|}{$\begin{array}{l}\text { Região(ões) Administrativa(s) afetada(s): Guará (RA X), Setor de Indústria e } \\
\text { Abastecimento (RA XXIX). }\end{array}$} \\
\hline \multicolumn{4}{|c|}{$\begin{array}{l}\text { Referência bibliográfica: LANSKY, Daniel. Chuva derruba parede no Guará. Correio } \\
\text { Braziliense, Brasília, } 1^{\circ} \text { de dez. de } 2007 \text {. Cidades, p. } 28 \text {. }\end{array}$} \\
\hline
\end{tabular}

\begin{tabular}{|c|c|c|c|}
\hline \multicolumn{3}{|c|}{ Notícia no 24} \\
\hline Dia: 26 & Página: 20 & Caderno: Cidades & Possui Fotos: Sim \\
\hline \multicolumn{3}{|l|}{ Título: Futuro do RK na Justiça } \\
\hline $\begin{array}{l}\text { Informações adicionais: Chuva forte causou a abertura de uma imensa cratera no } \\
\text { condomínio RK, em Sobradinho. Instalação de rede de águas pluviais na área }\end{array}$ \\
\hline
\end{tabular}


depende de autorização da justiça.

Desastre(s) Natural(is) associado(s) à reportagem: Erosão

Região(ões) Administrativa(s) afetada(s): Sobradinho (RA V).

Referência bibliográfica: MADER, Helena. Futuro do RK na Justiça. Correio

Braziliense, Brasília, 26 de dez. de 2007. Cidades, p. 20. 


\section{APÊNDICE IX}

\section{Desastres Naturais relacionados às chuvas no Distrito Federal relatados no jornal Correio Braziliense no ano de 2008}

\section{Janeiro}

\begin{tabular}{|c|c|c|c|}
\hline \multicolumn{4}{|c|}{ Notícia no 1} \\
\hline Dia: 28 & Página: 18 & Caderno: Cidades & Possui Fotos: Sim \\
\hline \multicolumn{4}{|c|}{ Título: Estado de emergência } \\
\hline \multicolumn{4}{|c|}{$\begin{array}{l}\text { Informações adicionais: Chuva complica a vida de moradores na Fercal e governo } \\
\text { do DF manda retirar da área } 60 \text { famílias da área, que são transferidas para a } \\
\text { Samambaia. O córrego Engenho Velho transbordou e inundou diversas casas, } \\
\text { causando diversas perdas materiais. Governador José Roberto Arruda visita o local e } \\
\text { ordena a derrubada de casas. No setor P Norte, na Ceilândia, duas casas desabaram } \\
\text { e outras foram alagadas pela chuva. }\end{array}$} \\
\hline \multicolumn{4}{|c|}{ Desastre(s) Natural(is) associado(s) à reportagem: Alagamento. } \\
\hline \multicolumn{4}{|c|}{ Região(ões) Administrativa(s) afetada(s): Ceilândia (RA IX). } \\
\hline
\end{tabular}

\section{Fevereiro}

\begin{tabular}{|c|c|c|c|}
\hline \multicolumn{4}{|c|}{ Notícia no 2} \\
\hline Dia: 04 & Página: 24 & Caderno: Cidades & Possui Fotos: Sim \\
\hline \multicolumn{4}{|c|}{ Título: Vila Cauhy tem 20 pontos de risco } \\
\hline \multicolumn{4}{|c|}{$\begin{array}{l}\text { Informações adicionais: Defesa Civil aponta } 128 \text { pontos de risco na Ceilândia, Ferca } \\
\text { e Estrutural e derruba } 72 \text { casas na Fercal. } 41 \text { famílias já foram desalojadas. Na Vila } \\
\text { Cauhy, no Núcleo Bandeirante, chuva formou lamaçais nas ruas e córrego Riacho } \\
\text { Fundo por pouco não transbordou e quase levando casas próximo ao leito. A } \\
\text { Estrutural também sofre com a lama. De acordo com o INMET em janeiro choveram } \\
197 \mathrm{~mm} \text {, abaixo da média de } 241 \mathrm{~mm} \text {. Entretanto, as chuvas dos últimos dias foram } \\
\text { intensas devido a uma frente fria semiestacionária que estava atuando na região } \\
\text { Sudeste e criou linhas de instabilidade. }\end{array}$} \\
\hline \multicolumn{4}{|c|}{ Desastre(s) Natural(is) associado(s) à reportagem: Alagamento. } \\
\hline
\end{tabular}


Referência bibliográfica: CASTRO, Jorge de. Vila Cauhy tem 20 pontos de risco. Correio Braziliense, Brasília, 4 de fev. de 2008. Cidades, p. 24.

\begin{tabular}{|c|c|c|c|}
\hline \multicolumn{4}{|c|}{ Notícia n 3} \\
\hline Dia: 07 & Página: 28 & Caderno: Cidades & Possui Fotos: Sim \\
\hline \multicolumn{4}{|c|}{ Título: Mais chuva até domingo } \\
\hline \multicolumn{4}{|c|}{$\begin{array}{l}\text { Informações adicionais: Estrutural e Taguatinga tem casas alagadas com as fortes } \\
\text { chuvas. Desde o início de fevereiro choveu apenas } 20 \mathrm{~mm} \text { no DF. No mesmo período } \\
\text { de } 2007 \text { foram } 60,5 \mathrm{~mm} \text {. Na última terça, dia 5, choveu } 7,4 \mathrm{~mm} \text {, mas volume ainda é } \\
\text { baixo, de acordo com o INMET. }\end{array}$} \\
\hline \multicolumn{4}{|c|}{ Desastre(s) Natural(is) associado(s) à reportagem: Alagamento. } \\
\hline \multicolumn{4}{|c|}{$\begin{array}{l}\text { Região(ões) Administrativa(s) afetada(s): Setor Complementar de Indústria e } \\
\text { Abastecimento (RA XXV). }\end{array}$} \\
\hline \multicolumn{4}{|c|}{$\begin{array}{l}\text { Referência bibliográfica: NERI, Márcia. Mais chuva até domingo. Correio Braziliense, } \\
\text { Brasília, } 7 \text { de fev. de 2008. Cidades, p. } 28 \text {. }\end{array}$} \\
\hline
\end{tabular}

\begin{tabular}{|c|c|c|c|}
\hline \multicolumn{4}{|c|}{ Notícia n 4} \\
\hline Dia: 10 & Página: 32 & Caderno: Cidades & Possui Fotos: Não \\
\hline \multicolumn{4}{|c|}{ Título: Homem é tragado pela enxurrada } \\
\hline \multicolumn{4}{|c|}{$\begin{array}{l}\text { Informações adicionais: O Corpo de Bombeiros encontrou ontem o corpo de um } \\
\text { homem que caiu em um brejo de Planaltina. Ele estava desaparecido desde o dia } 7 \text { de } \\
\text { fevereiro e caiu em uma vala, a menos de } 50 \mathrm{~m} \text { do local onde mora, que estava } \\
\text { submersa devido à forte chuva que caiu naquele dia, sendo levado pela enxurrada. } 0 \\
\text { homem morreu afogado. O corpo estava em um ponto de escoamento de águas } \\
\text { pluviais, a } 5 \mathrm{~km} \text { da casa onde morava. }\end{array}$} \\
\hline \multicolumn{4}{|c|}{ Desastre(s) Natural(is) associado(s) à reportagem: Enxurrada. } \\
\hline \multicolumn{4}{|c|}{ Região(ões) Administrativa(s) afetada(s): Planaltina (RA VI). } \\
\hline \multicolumn{4}{|c|}{$\begin{array}{l}\text { Referência bibliográfica: REDAÇÃO. Homem é tragado pela enxurrada. Correio } \\
\text { Braziliense, Brasília, } 10 \text { de fev. de } 2008 \text {. Cidades, p. } 32 \text {. }\end{array}$} \\
\hline
\end{tabular}




\begin{tabular}{|c|c|c|c|}
\hline \multicolumn{4}{|c|}{ Notícia n 5} \\
\hline Dia: 28 & Página: 12 & Caderno: Cidades & Possui Fotos: Sim \\
\hline \multicolumn{4}{|c|}{ Título: O drama de viver no improviso } \\
\hline \multicolumn{4}{|c|}{$\begin{array}{l}\text { Informações adicionais: Na QNR 5, de Ceilândia Norte, moradores vivem em } \\
\text { situação precária agravadas pelas chuvas, que formam lamaçais e alagam os } \\
\text { barracos. O lugar foi ocupado por moradores da antiga Vila Rafael, que foi destruída } \\
\text { em um incêndio e cedida aos moradores no final do mandato pela então governadora } \\
\text { Maria de Lourdes Abadia. Na QNR } 2 \text {, situação é ainda pior. Lixo e lama trazem mal } \\
\text { cheiro e causam doenças aos moradores. Como a região não possui infraestrutura de } \\
\text { saneamento básico, rede de águas pluviais e energia elétrica, a circunstância dos } \\
\text { moradores é agravada pela chegada das chuvas. }\end{array}$} \\
\hline \multicolumn{4}{|c|}{ Desastre(s) Natural(is) associado(s) à reportagem: Alagamento. } \\
\hline \multicolumn{4}{|c|}{ Região(ões) Administrativa(s) afetada(s): Ceilândia (RA IX). } \\
\hline $\begin{array}{l}\text { Referênci } \\
\text { Braziliens }\end{array}$ & $\begin{array}{l}\text { ibliográfica: } \\
\text { rasília, } 12 \text { de }\end{array}$ & $\begin{array}{l}\text { U, Marcelo. O drama } \\
\text { 2008. Cidades, p. } 28\end{array}$ & no improviso. Correio \\
\hline
\end{tabular}

\begin{tabular}{|c|c|c|c|}
\hline \multicolumn{4}{|c|}{ Notícia n 6} \\
\hline Dia: 22 & Página: 24 & Caderno: Cidades & Possui Fotos: Sim \\
\hline \multicolumn{4}{|c|}{ Título: Temporal leva risco à população } \\
\hline \multicolumn{4}{|c|}{$\begin{array}{l}\text { Informações adicionais: As } 12 \text { horas seguidas de chuva deixaram um rastro de } \\
\text { destruição pela capital: apenas nesse tempo choveu } 90 \mathrm{~mm} \text {, mais do que os } 60 \mathrm{~mm} \\
\text { registrados nos } 20 \text { primeiros dias de fevereiro. INMET alerta que volume não é } \\
\text { anormal nessa época do ano. O órgão calculou que, naquele em fevereiro de } 2007 \text {, } \\
\text { choveu } 210 \mathrm{~mm}, 60 \mathrm{~mm} \text { a mais que neste ano. Chuvas fortes ainda devem continuar } \\
\text { até meados de abril, quando se encerra o período chuvoso. O viaduto que liga a BR- } \\
070 \text { à Estrutural ficou alagado. O trânsito foi desviado para a EPTG e provocou } \\
\text { enormes engarrafamentos. Em Taguatinga, chuva provocou estragos em uma obra, } \\
\text { que foi interditada pela Defesa Civil, pois estava com a parede prestes a desabar. } \mathrm{Na} \\
\text { Ceilândia, Estrutural e Fercal, Defesa Civil pretende derrubar } 284 \text { casas em áreas de } \\
\text { risco. }\end{array}$} \\
\hline \multicolumn{4}{|c|}{ Desastre(s) Natural(is) associado(s) à reportagem: Alagamento. } \\
\hline \multicolumn{4}{|c|}{$\begin{array}{l}\text { Região(ões) Administrativa(s) afetada(s): Guará (RA X), Taguatinga (RA III), Setor } \\
\text { Complementar de Indústria e Abastecimento (RA XXV). }\end{array}$} \\
\hline \multicolumn{4}{|c|}{$\begin{array}{l}\text { Referência bibliográfica: TOSCANO, Isabel. Temporal leva risco à população. } \\
\text { Correio Braziliense, Brasília, } 22 \text { de fev. de } 2008 \text {. Cidades, p. } 24 \text {. }\end{array}$} \\
\hline
\end{tabular}




\begin{tabular}{|l|l|l|l|} 
Dia: 22 & Página: 24 & Caderno: Cidades & Possui Fotos: Sim \\
\hline
\end{tabular}

Título: Perigo em escola de Santa Maria

Informações adicionais: Na Escola Classe 203 alunos assistiram aulas em salas alagadas com água e lama devido a chuva forte de ontem. Chuva também deixou a fiação elétrica exposta, que já causou um acidente com um aluno e alagou casas próximas a escola, alagando e provocando rachaduras nas paredes das residências. Defesa Civil interditou uma casa e removeu uma família do lugar.

Desastre(s) Natural(is) associado(s) à reportagem: Alagamento.

Região(ões) Administrativa(s) afetada(s): Santa Maria (RA XIII).

Referência bibliográfica: TOSCANO, Isabel. Perigo em escola de Santa Maria. Correio Braziliense, Brasília, 22 de fev. de 2008. Cidades, p. 24.

\begin{tabular}{|c|c|c|c|}
\hline \multicolumn{4}{|c|}{ Notícia nㅇ 8} \\
\hline Dia: 23 & Página: 34 & Caderno: Cidades & Possui Fotos: Sim \\
\hline \multicolumn{4}{|c|}{ Título: Previsão de chuvas no fim de semana } \\
\hline \multicolumn{4}{|c|}{$\begin{array}{l}\text { Informações adicionais: Chuva localizada, próxima ao aeroporto provoca } \\
\text { alagamento na Avenida das Nações. INMET registrou apenas } 0,2 \text { mm no período, } \\
\text { volume considerado normal pelos meteorologistas. Muitos carros quebraram nos } \\
\text { pontos alagados. }\end{array}$} \\
\hline \multicolumn{4}{|c|}{ Desastre(s) Natural(is) associado(s) à reportagem: Alagamento. } \\
\hline \multicolumn{4}{|c|}{ Região(ões) Administrativa(s) afetada(s): Brasília (RA I). } \\
\hline \multicolumn{4}{|c|}{$\begin{array}{l}\text { Referência bibliográfica: TECLES, Elisa; Castro, Jorge de. Previsão de chuvas no } \\
\text { fim de semana. Correio Braziliense, Brasília, } 23 \text { de fev. de 2008. Cidades, p. } 34 \text {. }\end{array}$} \\
\hline
\end{tabular}

\begin{tabular}{|c|c|c|c|}
\hline \multicolumn{3}{|c|}{ Notícia no 9} \\
\hline Dia: 24 & Página: 27 & \multicolumn{1}{|c|}{ Caderno: Cidades } & Possui Fotos: Sim \\
\hline Título: Prejuízos da chuva \\
\hline
\end{tabular}


Brasília. Em todo o mês, foram $152 \mathrm{~mm}$. A média é de $214 \mathrm{~mm}$ no mês fevereiro.

Desastre(s) Natural(is) associado(s) à reportagem: Alagamento.

Região(ões) Administrativa(s) afetada(s): Taguatinga (RA III).

Referência bibliográfica: CASTRO, Jorge de. Prejuízos da chuva. Correio

Braziliense, Brasília, 24 de fev. de 2008. Cidades, p. 27.

\begin{tabular}{|c|c|c|c|}
\hline \multicolumn{4}{|c|}{ Notícia n 10} \\
\hline Dia: 25 & Página: 28 & Caderno: Cidades & Possui Fotos: Sim \\
\hline \multicolumn{4}{|c|}{ Título: Chuvas mais leves durante a semana } \\
\hline \multicolumn{4}{|c|}{$\begin{array}{l}\text { Informações adicionais: INMET prevê chuvas mais leves a partir de março devido ao } \\
\text { tempo estável. Este ano, o órgão já registrou o total de } 348 \mathrm{~mm}^{3} \text { de chuvas. O volume } \\
\text { é bem menor do que o registrado no mesmo período de } 2006 \text {, quando foram } \\
\text { registrados } 489,1 \mathrm{~mm} \text {. Para janeiro, era esperado que as chuvas atingissem } 241 \mathrm{~mm} \text {, } \\
\text { mas elas não ultrapassaram } 196 \mathrm{~mm} \text {. Para este mês, a estimativa é que as chuvas } \\
\text { cheguem a } 214,7 \mathrm{~mm} \text {, mas até o momento, foram registrados } 152 \mathrm{~mm} \text {. Chuva causou } \\
\text { alagamentos ontem nas vias do Plano Piloto, mas não provocou acidentes. }\end{array}$} \\
\hline \multicolumn{4}{|c|}{ Desastre(s) Natural(is) associado(s) à reportagem: Alagamento. } \\
\hline \multicolumn{4}{|c|}{ Região(ões) Administrativa(s) afetada(s): Brasília (RA I). } \\
\hline \multicolumn{4}{|c|}{$\begin{array}{l}\text { Referência bibliográfica: BORGES, Priscilla. Chuvas mais leves durante a semana. } \\
\text { Correio Braziliense, Brasília, } 25 \text { de fev. de } 2008 \text {. Cidades, p. } 28 .\end{array}$} \\
\hline
\end{tabular}

\begin{tabular}{|c|c|c|c|}
\hline \multicolumn{4}{|c|}{ Notícia nำ 11} \\
\hline Dia: 28 & Página: 39 & Caderno: Cidades & Possui Fotos: Sim \\
\hline \multicolumn{4}{|c|}{ Título: Temporal alaga vias no Plano } \\
\hline \multicolumn{4}{|c|}{$\begin{array}{l}\text { Informações adicionais: Temporal pega brasiliense de surpresa no meio da tarde, } \\
\text { deixando as tesourinhas e o trecho entre a } 402 \text { e } 202 \text { Norte intransitáveis. Água } \\
\text { alagou também avenida N2 e causou panes em carros que tentavam atravessar as } \\
\text { enxurradas. INMET diz que temporais são comuns nessa época do ano. }\end{array}$} \\
\hline \multicolumn{4}{|c|}{ Desastre(s) Natural(is) associado(s) à reportagem: Alagamento, enxurrada. } \\
\hline \multicolumn{4}{|c|}{ Região(ões) Administrativa(s) afetada(s): Brasília (RA I). } \\
\hline \multicolumn{4}{|c|}{$\begin{array}{l}\text { Referência bibliográfica: REDAÇÃO. Temporal alaga vias no Plano. Correio } \\
\text { Braziliense, Brasília, } 28 \text { de fev. de } 2008 \text {. Cidades, p. } 39 \text {. }\end{array}$} \\
\hline
\end{tabular}




\section{Março}

\begin{tabular}{|c|c|c|c|}
\hline \multicolumn{4}{|c|}{ Notícia nº 12} \\
\hline Dia: 01 & Página: 32 & Caderno: Cidades & Possui Fotos: Sim \\
\hline \multicolumn{4}{|c|}{ Título: Trânsito problemático } \\
\hline \multicolumn{4}{|c|}{$\begin{array}{l}\text { Informações adicionais: Defesa Civil registra alagamentos na Fercal, em } \\
\text { Sobradinho, Vila Cauhy, no Núcleo Bandeirante e na Vila do IAPI, em Ceilândia. Na } \\
\text { Fercal, } 75 \text { casas foram demolidas e outras } 43 \text { estão em vias de ir ao chão. } \\
\text { Tesourinhas e Avenida das Nações ficaram alagadas no Plano Piloto. Chuva também } \\
\text { deixou trânsito parado na EPTG com os alagamentos. Segundo o o INMET em } \\
\text { fevereiro choveu mais do que o normal. A média para o mês é de } 214 \text { milímetros. No } \\
\text { segundo mês deste ano, o órgão registrou } 242,5 \text { milímetros. }\end{array}$} \\
\hline \multicolumn{4}{|c|}{ Desastre(s) Natural(is) associado(s) à reportagem: Alagamento. } \\
\hline \multicolumn{4}{|c|}{$\begin{array}{l}\text { Região(ões) Administrativa(s) afetada(s): Brasília (RA I), Ceilândia (RA IX), Núcleo } \\
\text { Bandeirante (RA VIII), Guará (RA X), Taguatinga (RA III), Fercal (RA XXXI) }\end{array}$} \\
\hline \multicolumn{4}{|c|}{$\begin{array}{l}\text { Referência bibliográfica: NERI, Márcia. Trânsito problemático. Correio Braziliense, } \\
\text { Brasília, } 1^{\circ} \text { de mar. de } 2008 \text {. Cidades, p. } 39 .\end{array}$} \\
\hline
\end{tabular}

\begin{tabular}{|c|c|c|c|}
\hline \multicolumn{4}{|c|}{ Notícia nำ 13} \\
\hline Dia: 28 & Página: 32 & Caderno: Cidades & Possui Fotos: Sim \\
\hline \multicolumn{4}{|c|}{ Título: Chuva provoca queda de temperatura e acidentes } \\
\hline \multicolumn{4}{|c|}{$\begin{array}{l}\text { Informações adicionais: Chuva de } 21 \mathrm{~mm} \text { de ontem provocou a queda brusca da } \\
\text { temperatura na capital e também diversos acidentes de trânsito e engarrafamentos } \\
\text { nas W3 Sul e Norte e na EPTG em Águas Claras. Acidente mais sério ocorreu na via } \\
\text { EPIA, onde caminhão do CEASA tentou sair de trás de uma carreta e tombou na pista. } \\
\text { Não houve feridos. }\end{array}$} \\
\hline \multicolumn{4}{|c|}{ Desastre(s) Natural(is) associado(s) à reportagem: Alagamento. } \\
\hline \multicolumn{4}{|c|}{ Região(ões) Administrativa(s) afetada(s): Águas Claras (RA XX), Brasília (RA I). } \\
\hline \multicolumn{4}{|c|}{$\begin{array}{l}\text { Referência bibliográfica: MONTENEGRO, Érica. Chuva provoca queda de } \\
\text { temperatura e acidentes. Correio Braziliense, Brasília, } 28 \text { de mar. de } 2008 \text {. Cidades, p. } \\
32 .\end{array}$} \\
\hline
\end{tabular}

Abril 


\begin{tabular}{|c|c|c|c|}
\hline \multicolumn{4}{|c|}{ Notícia nำ 14} \\
\hline Dia: 17 & Página: 37 & Caderno: Cidades & Possui Fotos: \\
\hline \multicolumn{4}{|c|}{ Título: Temporal e ventania assustam população } \\
\hline \multicolumn{4}{|c|}{$\begin{array}{l}\text { Informações adicionais: Posto de Saúde no } 1 \text {, segundo andar do prédio da Defesa } \\
\text { Civil e algumas casas foram destelhadas com forte temporal de } 20 \text { minutos que caiu } \\
\text { na Ceilândia no final da tarde. QNM } 18 \text { e } 19 \text { ficou sem energia elétrica. Muro do } \\
\text { quartel do Corpo de Bombeiros caiu e semáforos deixaram de funcionar. }\end{array}$} \\
\hline \multicolumn{4}{|c|}{ Desastre(s) Natural(is) associado(s) à reportagem: Vendaval. } \\
\hline \multicolumn{4}{|c|}{ Região(ões) Administrativa(s) afetada(s): Ceilândia (RA IX). } \\
\hline $\begin{array}{l}\text { Referênci } \\
\text { Correio } B r\end{array}$ & $\begin{array}{l}\text { bliográfica: } \mathrm{F} \\
\text { ense, Brasília }\end{array}$ & $\begin{array}{l}\tilde{A} O \text {. Temporal e ven } \\
\text { abr. de 2008. Cidad }\end{array}$ & Istam população. \\
\hline
\end{tabular}

\section{Setembro}

\begin{tabular}{|c|c|c|c|}
\hline \multicolumn{4}{|c|}{ Notícia nํ 15} \\
\hline Dia: 20 & Página: 40 & Caderno: Cidades & Possui Fotos: Sim \\
\hline \multicolumn{4}{|c|}{ Título: Enfim, a chuva chegou } \\
\hline \multicolumn{4}{|c|}{$\begin{array}{l}\text { Informações adicionais: A primeira chuva forte desta temporada, com ventos de até } \\
36 \mathrm{~km} / \mathrm{h} \text {, derrubou uma árvore sobre sete carros na Quadra } 2 \text { do Setor de } \\
\text { Abastecimento e Armazenagem Norte (SAAN) e uma parede de um prédio em } \\
\text { construção sobre o telhado de uma casa na Estrutural. O call center da CEB recebeu } \\
5,6 \text { mil ligações entre as } 16 \mathrm{~h} \text { e as } 19 \mathrm{~h} \text {. A maioria das chamadas foram de Ceilândia, } \\
\text { Gama, Samambaia e Taguatinga por causa de problemas na rede elétrica. Corpo de } \\
\text { Bombeiros registrou um acidente de trânsito próximo ao Instituto Médico Legal. A } \\
\text { estação do INMET no Recanto das Emas registrou } 4 \mathrm{~mm} \text { de precipitação. Ruas de } \\
\text { alguns bairros de Taguatinga ficaram alagadas. }\end{array}$} \\
\hline \multicolumn{4}{|c|}{ Desastre(s) Natural(is) associado(s) à reportagem: Alagamento, vendaval. } \\
\hline \multicolumn{4}{|c|}{$\begin{array}{l}\text { Região(ões) Administrativa(s) afetada(s): Brasília (RA I), Ceilândia (RA IX), Gama } \\
\text { (RA III), Samambaia (RA XII), Setor Complementar de Indústria e Abastecimento (RA } \\
\text { XXV), Taguatinga (RA III). }\end{array}$} \\
\hline \multicolumn{4}{|c|}{$\begin{array}{l}\text { Referência bibliográfica: CUNHA, Teresa. Enfim, a chuva chegou. Correio } \\
\text { Braziliense, Brasília, } 20 \text { de set. de } 2008 \text {. Cidades, p. } 40 \text {. }\end{array}$} \\
\hline
\end{tabular}

\section{Notícia $\mathrm{n}$ - 16}




\begin{tabular}{|c|c|c|c|}
\hline Dia: 26 & Página: 27 & Caderno: Cidades & Possui Fotos: Sim \\
\hline \multicolumn{4}{|c|}{ Título: Falta de energia pára Brasília } \\
\hline \multicolumn{4}{|c|}{$\begin{array}{l}\text { Informações adicionais: Temporal que caiu no final da tarde de ontem causou } \\
\text { quedas de energia em vários pontos do Plano Piloto: No Cruzeiro, Setor de Indústrias } \\
\text { Gráficas (SIG), Eixo Monumental e EPIA, vários semáforos ficaram desligados, } \\
\text { provocando vários engarrafamentos no trânsito. A queda também foi sentida na Asa } \\
\text { Norte, sendo que várias pesquisas foram perdidas na Universidade de Brasília. QL } 10 \\
\text { e } 20 \text { do Lago Sul ficaram três horas sem luz. Santa Maria ficou } 15 \text { horas sem energia } \\
\text { e na quadra } 308 \text { uma padaria perdeu cerca de } 1,5 \text { mil pães. Segundo a CEB, queda } \\
\text { de energia foi causada pela queda de uma árvore sobre quatro circuitos de } \\
\text { transmissão na EPIA, provavelmente devido aos ventos fortes ou descarga elétrica. O } \\
\text { INMET registrou um volume de água de } 20 \mathrm{~mm} \text {, considerado normal para o período } \\
\text { das primeiras chuvas. }\end{array}$} \\
\hline \multicolumn{4}{|c|}{ Desastre(s) Natural(is) associado(s) à reportagem: Vendaval. } \\
\hline \multicolumn{4}{|c|}{$\begin{array}{l}\text { Região(ões) Administrativa(s) afetada(s): Brasília (RA I), Cruzeiro (RA XI), Lago Sul } \\
\text { (RA XVI), Santa Maria (RA XIII). }\end{array}$} \\
\hline \multicolumn{4}{|c|}{$\begin{array}{l}\text { Referência bibliográfica: TOSCANO, Izabel. Falta de energia pára Brasília. Correio } \\
\text { Braziliense, Brasília, } 26 \text { de set. de } 2008 \text {. Cidades, p. } 27 .\end{array}$} \\
\hline
\end{tabular}

\section{Outubro}

\begin{tabular}{|c|c|c|c|}
\hline \multicolumn{4}{|c|}{ Notícia nํ 17} \\
\hline Dia: 30 & Página: 37 & Caderno: Cidades & Possui Fotos: Sim \\
\hline \multicolumn{4}{|c|}{ Título: Temporal e granizo assustam o Gama } \\
\hline \multicolumn{4}{|c|}{$\begin{array}{l}\text { Informações adicionais: Retorno da temporada de chuvas causou alagamentos, } \\
\text { queda de granizo e ventanias no Gama. No Setor Oeste do Gama, árvore caiu em } \\
\text { cima de uma caminhonete e a ventania destelhou uma casa. No Setor Sul, outra } \\
\text { árvore caiu sobre uma casa. Em Santa Maria, várias casas ficaram alagadas. } \\
\text { Bombeiros atenderam } 17 \text { chamados em apenas } 30 \text { minutos. }\end{array}$} \\
\hline \multicolumn{4}{|c|}{ Desastre(s) Natural(is) associado(s) à reportagem: Alagamento, granizo, vendaval } \\
\hline \multicolumn{4}{|c|}{ Região(ões) Administrativa(s) afetada(s): Gama (RA II), Santa Maria (RA XIII). } \\
\hline \multicolumn{4}{|c|}{$\begin{array}{l}\text { Referência bibliográfica: COSTI, Lúcio. Temporal e granizo assustam o Gama. } \\
\text { Correio Braziliense, Brasília, } 30 \text { de out. de 2008. Cidades, p. } 37 .\end{array}$} \\
\hline
\end{tabular}

\section{Notícia $n^{0} 18$}




\begin{tabular}{|c|c|c|c|}
\hline Dia: 30 & Página: 37 & Caderno: Cidades & Possui Fotos: Sim \\
\hline \multicolumn{4}{|c|}{ Título: Mais duas semanas de instabilidade no DF } \\
\hline \multicolumn{4}{|c|}{$\begin{array}{l}\text { Informações adicionais: DF registrou recorde de calor. Foram } 35,8^{\circ} \mathrm{C} \text { de acordo } \\
\text { com o INMET, temperatura mais alta desde que começaram as medições. Massa de } \\
\text { ar seco e quente está provocando as altas temperaturas e também bloqueando as } \\
\text { frentes frias e a umidade da Amazônia, de acordo com pesquisadora da Universidade } \\
\text { Federal do Goiás (UFG). Altas temperaturas também contribuem para formação das } \\
\text { chuvas intensas que tem provocado a queda de granizo em diversos pontos da } \\
\text { cidade, que antecedem as chuvas. }\end{array}$} \\
\hline \multicolumn{4}{|c|}{ Desastre(s) Natural(is) associado(s) à reportagem: Granizo. } \\
\hline \multicolumn{4}{|c|}{ Região(ões) Administrativa(s) afetada(s): Brasília (RA I). } \\
\hline \multicolumn{4}{|c|}{$\begin{array}{l}\text { Referência bibliográfica: VELEDA, Raphael. Mais duas semanas de instabilidade no } \\
\text { DF. Correio Braziliense, Brasília, } 30 \text { de out. de } 2008 \text {. Cidades, p. } 37 \text {. }\end{array}$} \\
\hline
\end{tabular}

\begin{tabular}{|c|c|c|c|}
\hline \multicolumn{4}{|c|}{ Notícia nํ 19} \\
\hline Dia: 31 & Página: 28 & Caderno: Cidades & Possui Fotos: Sim \\
\hline \multicolumn{4}{|c|}{ Título: Chuva provoca apagão e acidentes } \\
\hline \multicolumn{4}{|c|}{$\begin{array}{l}\text { Informações adicionais: Com chuva forte os brasilienses se envolveram em } \\
\text { acidentes de trânsito, tiveram veículos danificados em rodovias, ficaram presos em } \\
\text { elevadores, garagens de shoppings, ou sofreram com falta de energia elétrica em } \\
\text { vários pontos do Distrito Federal, como a Asa Norte, o Setor de Indústrias Gráficas, } \\
\text { Sudoeste, Eixo Monumental e o Parque da Cidade. No Setor Comercial Norte, um } \\
\text { problema na subestação da CEB deixou a região sem energia durante quase toda a } \\
\text { tarde. Um acidente envolvendo oito veículos complicou o trânsito na BR-020 próxima } \\
\text { ao viaduto do Colorado. }\end{array}$} \\
\hline \multicolumn{4}{|c|}{ Desastre(s) Natural(is) associado(s) à reportagem: Granizo. } \\
\hline \multicolumn{4}{|c|}{$\begin{array}{l}\text { Região(ões) Administrativa(s) afetada(s): Brasília (RA I), Sobradinho (RA V), } \\
\text { Sudoeste / Octogonal (RA XXII). }\end{array}$} \\
\hline \multicolumn{4}{|c|}{$\begin{array}{l}\text { Referência bibliográfica: CUNHA, Teresa. Chuva provoca apagão e acidentes. } \\
\text { Correio Braziliense, Brasília, } 31 \text { de out. de } 2008 \text {. Cidades, p. } 28 \text {. }\end{array}$} \\
\hline
\end{tabular}

\section{Novembro}




\begin{tabular}{|c|c|c|c|}
\hline \multicolumn{4}{|c|}{ Notícia nº 20} \\
\hline Dia: 09 & Página: 38 & Caderno: Cidades & Possui Fotos: Sim \\
\hline \multicolumn{4}{|c|}{ Título: Uma hora de chuva e muito estrago } \\
\hline \multicolumn{4}{|c|}{$\begin{array}{l}\text { Informações adicionais: Temporal com ventos de } 60 \mathrm{~km} / \mathrm{h} \text { deixou rastro de } \\
\text { destruição pelo Plano Piloto na tarde de ontem. Houve queda de árvores, alagamentos } \\
\text { e o trânsito ficou congestionado. Corpo de bombeiros atendeu } 13 \text { chamados. Na Ponte } \\
\text { JK, vento arrancou árvores. Tesourinhas das quadras } 209 \text { e } 210 \text { Norte ficaram } \\
\text { alagadas, juntamente com o Centro de Obstetrícia do Hospital Regional da Asa Sul } \\
\text { (HRAS). Chuva também alagou a quadra } 511 \text { Norte e uma loja de calçados na } 405 \\
\text { Norte. Árvore caiu sobre carro na } 211 \text { Norte. Em pouco mais de uma hora, os } \\
\text { aparelhos do INMET registraram } 9 \mathrm{~mm} \text { de chuva, volume considerado normal para o } \\
\text { período. }\end{array}$} \\
\hline \multicolumn{4}{|c|}{ Desastre(s) Natural(is) associado(s) à reportagem: Alagamento, vendaval. } \\
\hline \multicolumn{4}{|c|}{ Região(ões) Administrativa(s) afetada(s): Brasília (RA I). } \\
\hline \multicolumn{4}{|c|}{$\begin{array}{l}\text { Referência bibliográfica: TECLES, Elisa; GONTIJO, Yale; MADER, Helena. Uma } \\
\text { hora de chuva e muito estrago. Correio Braziliense, Brasília, } 9 \text { de nov. de } 2008 . \\
\text { Cidades, p. } 38 .\end{array}$} \\
\hline
\end{tabular}

\begin{tabular}{|c|c|c|c|}
\hline \multicolumn{4}{|c|}{ Notícia nำ 21} \\
\hline Dia: 10 & Página: 17 & Caderno: Cidades & Possui Fotos: Sim \\
\hline \multicolumn{4}{|c|}{ Título: Ventania fez até ferro voar } \\
\hline \multicolumn{4}{|c|}{$\begin{array}{l}\text { Informações adicionais: Ventos de até } 60 \mathrm{~km} / \mathrm{h} \text { derrubaram árvores na } 311 \text { e } 110 \\
\text { Norte e fizeram pedaços de ferro de cobertura de bloco voar e atingir janelas durante } \\
\text { forte temporal no dia } 8 \text {. Queda de árvore provocou estrago em padaria na } 110 \text { Norte, } \\
\text { que teve cobertura bastante danificada. W3 Norte tinha várias árvores caídas nas ruas } \\
\text { e alagamentos, que causaram congestionamentos. Polícia Rodoviária Federal } \\
\text { registrou } 10 \text { colisões nas estradas do DF. INMET disse que temporais são normais na } \\
\text { época de transição da seca para o período chuvoso. }\end{array}$} \\
\hline \multicolumn{4}{|c|}{ Desastre(s) Natural(is) associado(s) à reportagem: Alagamento, vendaval. } \\
\hline \multicolumn{4}{|c|}{ Região(ões) Administrativa(s) afetada(s): Brasília (RA I). } \\
\hline \multicolumn{4}{|c|}{$\begin{array}{l}\text { Referência bibliográfica: TECLES, Elisa. Ventania fez até ferro voar. Correio } \\
\text { Braziliense, Brasília, } 10 \text { de nov. de 2008. Cidades, p. } 17 .\end{array}$} \\
\hline
\end{tabular}

\section{Notícia no 22}




\begin{tabular}{|c|c|c|c|}
\hline Dia: 11 & Página: 29 & Caderno: Cidades & Possui Fotos: Sim \\
\hline \multicolumn{4}{|c|}{ Título: Mais uma semana de temporais } \\
\hline \multicolumn{4}{|c|}{$\begin{array}{l}\text { Informações adicionais: Ontem, choveu } 6,1 \text { milímetros no Plano Piloto de acordo } \\
\text { com o INMET. Aguaceiro trouxe transtornos para o brasiliense. Alagamentos e } \\
\text { enxurrada causaram engarrafamentos no Eixão Sul, EPTG e via Estrutural. Defesa } \\
\text { Civil irá desalojar } 287 \text { famílias no Núcleo Bandeirante, Ceilândia e Sobradinho. A } \\
\text { chuva também causou quedas de energia no Lago Sul. }\end{array}$} \\
\hline \multicolumn{4}{|c|}{ Desastre(s) Natural(is) associado(s) à reportagem: Alagamento, enxurrada. } \\
\hline \multicolumn{4}{|c|}{$\begin{array}{l}\text { Região(ões) Administrativa(s) afetada(s): Brasília (RA I), Guará (RA X), Setor } \\
\text { Complementar de Indústria e Abastecimento (RA XXV), Taguatinga (RA III). }\end{array}$} \\
\hline \multicolumn{4}{|c|}{$\begin{array}{l}\text { Referência bibliográfica: RODRIGUES, Gizella. Mais uma semana de temporais. } \\
\text { Correio Braziliense, Brasília, } 11 \text { de nov. de 2008. Cidades, p. } 29 .\end{array}$} \\
\hline
\end{tabular}

\begin{tabular}{|c|c|c|c|}
\hline \multicolumn{4}{|c|}{ Notícia nㅇ 23} \\
\hline Dia: 12 & Página: 27 & Caderno: Cidades & Possui Fotos: Sim \\
\hline \multicolumn{4}{|c|}{ Título: Chuva ameaça construções } \\
\hline \multicolumn{4}{|c|}{$\begin{array}{l}\text { Informações adicionais: Apenas } 33 \text { milímetros até as } 20 \text { h foram suficientes para } \\
\text { provocar acidentes de veículos e engarrafamentos no trânsito, falta de energia elétrica, } \\
\text { interdição de casas, destelhamentos, derrubada de árvores, entre outros estragos em } \\
\text { várias regiões. INMET diz que chuvas estão dentro do normal e comparam o } \\
\text { novembro deste ano com o mês de novembro de } 2007 \text {. De 10 a } 11 \text { de } 2007 \text {, choveram } \\
140 \text { milímetros. Este ano, nesses } 11 \text { dias, foram } 62 \text { milímetros. Chuva também alagou } \\
\text { dois laboratórios do Hospital Regional de Planaltina (HRP). }\end{array}$} \\
\hline \multicolumn{4}{|c|}{ Desastre(s) Natural(is) associado(s) à reportagem: Alagamento, vendaval. } \\
\hline \multicolumn{4}{|c|}{$\begin{array}{l}\text { Região(ões) Administrativa(s) afetada(s): Park Way (RA XXIV), Planaltina (RA VI), } \\
\text { Samambaia (RA XII), Sobradinho (RA V), Sobradinho II (RA XXVI), Taguatinga (RA } \\
\text { III). }\end{array}$} \\
\hline \multicolumn{4}{|c|}{$\begin{array}{l}\text { Referência bibliográfica: CUNHA, Teresa. Chuva ameaça construções. Correio } \\
\text { Braziliense, Brasília, } 12 \text { de nov. de 2008. Cidades, p. } 27 \text {. }\end{array}$} \\
\hline
\end{tabular}

\section{Notícia $\mathrm{n}$ ㅇ 24}




\begin{tabular}{|c|c|c|c|}
\hline Dia: 27 & Página: 35 & Caderno: Cidades & Possui Fotos: Não \\
\hline \multicolumn{4}{|c|}{ Título: Alagamentos em Ceilândia } \\
\hline \multicolumn{4}{|c|}{$\begin{array}{l}\text { Informações adicionais: Chuva provoca diversos alagamentos na Ceilândia, } \\
\text { especialmente na DF-095, que liga a região administrativa ao Plano Piloto. Três } \\
\text { famílias serão desalojadas do Condomínio Sol Nascente. }\end{array}$} \\
\hline \multicolumn{4}{|c|}{ Desastre(s) Natural(is) associado(s) à reportagem: Alagamento. } \\
\hline \multicolumn{4}{|c|}{ Região(ões) Administrativa(s) afetada(s): Ceilândia (RA IX). } \\
\hline $\begin{array}{l}\text { Referênci } \\
\text { Braziliens }\end{array}$ & $\begin{array}{l}\text { Jliográfica: V } \\
\text { asília, } 27 \text { de } n\end{array}$ & $\begin{array}{l}\text { A, Raphael. Alagam } \\
\text { 2008. Cidades, p. } 3\end{array}$ & Ceilândia. Correio \\
\hline
\end{tabular}

\begin{tabular}{|c|c|c|c|}
\hline \multicolumn{4}{|c|}{ Notícia nํ 25} \\
\hline Dia: 29 & Página: 37 & Caderno: Cidades & Possui Fotos: Sim \\
\hline \multicolumn{4}{|c|}{ Título: Sexta-feira encharcada nas vias } \\
\hline \multicolumn{4}{|c|}{$\begin{array}{l}\text { Informações adicionais: A sexta-feira foi de mais chuva na capital do que no estado } \\
\text { de Santa Catarina, onde } 99 \text { pessoas morreram e } 78 \text { mil estão desabrigadas em virtude } \\
\text { das constantes tormentas dos últimos dias. O Instituto Nacional de Meteorologia } \\
\text { (INMET) registrou } 63 \mathrm{~mm} \text { por aqui, contra } 9 \mathrm{~mm} \text { na região catarinense. Chuva alagou } \\
\text { as pistas da 102, } 611,707 \text { e L3 Norte e do Setor de Autarquias Sul. Na QI } 27 \text { do Lago } \\
\text { Sul enxurrada invadiu casa e formou um grande lamaçal, enquanto na QI } 25 \text {, um muro } \\
\text { caiu. }\end{array}$} \\
\hline \multicolumn{4}{|c|}{ Desastre(s) Natural(is) associado(s) à reportagem: Alagamento, enxurrada. } \\
\hline \multicolumn{4}{|c|}{ Região(ões) Administrativa(s) afetada(s): Brasília (RA I), Lago Sul (RA XVI). } \\
\hline \multicolumn{4}{|c|}{$\begin{array}{l}\text { Referência bibliográfica: REDAÇÃO. Sexta-feira encharcada nas vias. Correio } \\
\text { Braziliense, Brasília, } 29 \text { de nov. de 2008. Cidades, p. } 37 .\end{array}$} \\
\hline
\end{tabular}

\begin{tabular}{|c|c|c|c|}
\hline \multicolumn{4}{|c|}{ Notícia n 26} \\
\hline Dia: 29 & Página: 37 & Caderno: Cidades & Possui Fotos: Sim \\
\hline \multicolumn{4}{|c|}{ Título: Risco aumenta nas áreas carentes } \\
\hline \multicolumn{4}{|c|}{$\begin{array}{l}\text { Informações adicionais: Na Ceilândia, chuva forte arrancou parte do asfalto dos } \\
\text { condomínios Pôr do Sol e Sol Nascente, formando grandes lamaçais que estão } \\
\text { fazendo muitos carros atolarem. Com a enxurrada, buracos nas vias também } \\
\text { aumentam. }\end{array}$} \\
\hline
\end{tabular}


Desastre(s) Natural(is) associado(s) à reportagem: Enxurrada.

Região(ões) Administrativa(s) afetada(s): Ceilândia (RA I).

Referência bibliográfica: AMORIM, Diego. Risco aumenta nas áreas carentes.

Correio Braziliense, Brasília, 29 de nov. de 2008. Cidades, p. 37. 


\section{APÊNDICE X}

\section{Desastres Naturais relacionados às chuvas no Distrito Federal relatados no jornal Correio Braziliense no ano de 2009}

Janeiro

\begin{tabular}{|c|c|c|c|}
\hline \multicolumn{4}{|c|}{ Notícia no 1} \\
\hline Dia: 09 & Página: 21 & Caderno: Cidades & Possui Fotos: Sim \\
\hline \multicolumn{4}{|c|}{ Título: Temporal de parar a cidade } \\
\hline \multicolumn{4}{|c|}{$\begin{array}{l}\text { Informações adicionais: A tempestade que caiu na tarde do dia 8, por volta das } \\
14 \text { h30 no Plano Piloto, provocou alagamentos, estouros de encanamento, } \\
\text { congestionamentos, paralisação do metrô, quedas de árvore e falta de energia elétrica } \\
\text { em parte do Distrito Federal. Segundo o INMET, choveu } 14,4 \mathrm{~mm} \text { em duas horas. } \\
\text { Quadras } 102,103,105,202 / 203,302,402 \text { e } 602 \text { Sul e } 406 \text { Norte foram as mais } \\
\text { atingidas. }\end{array}$} \\
\hline \multicolumn{4}{|c|}{ Desastre(s) Natural(is) associado à reportagem: Alagamento, enxurrada, vendaval. } \\
\hline \multicolumn{4}{|c|}{ Região(ões) Administrativa(s) afetada(s): Brasília (RA I), Itapoã (RA XXVIII). } \\
\hline $\begin{array}{l}\text { Referênc } \\
\text { Correio } B\end{array}$ & $\begin{array}{l}\text { liográfica: } F \\
\text { ense, Brasília }\end{array}$ & $\begin{array}{l}\text { Maria. Chuvas de } f \\
\text { jan. de 2009. Cidac }\end{array}$ & omeçam mais fortes. \\
\hline
\end{tabular}

\begin{tabular}{|c|c|c|c|}
\hline \multicolumn{4}{|c|}{ Notícia n 2} \\
\hline Dia: 10 & Página: 27 & Caderno: Cidades & Possui Fotos: Sim \\
\hline \multicolumn{4}{|c|}{ Título: Chuva e vento castigam a Ceilândia } \\
\hline \multicolumn{4}{|c|}{$\begin{array}{l}\text { Informações adicionais: Ceilândia sofre com forte chuva que caiu por todo o Distrito } \\
\text { Federal. Em apenas uma hora de chuva várias famílias ficaram desabrigadas nas } \\
\text { QNRs. Ventos fortes derrubaram muros, levantaram telhas e danificaram carros. } \\
\text { Algumas pessoas ficaram feridas. }\end{array}$} \\
\hline \multicolumn{4}{|c|}{ Desastre(s) Natural(is) associado(s) à reportagem: Alagamento, vendaval. } \\
\hline \multicolumn{4}{|c|}{ Região(ões) Administrativa(s) afetada(s): Ceilândia (RA IX). } \\
\hline \multicolumn{4}{|c|}{$\begin{array}{l}\text { Referência bibliográfica: FILGUEIRA, Ary. Chuva e vento castigam a Ceilândia. } \\
\text { Correio Braziliense, Brasília, } 10 \text { de jan. de 2009. Cidades, p. } 27 \text {. }\end{array}$} \\
\hline
\end{tabular}

Março 


\section{Notícia no 3}

\begin{tabular}{c|c|c|c|} 
Dia: 10 & Página: 26 & Caderno: Cidades & Possui Fotos: Sim
\end{tabular}

Título: Cratera ameaça ribeirão e casas

Informações adicionais: Força da água das chuvas e a ocupação urbana desordenada formaram cratera que fica entre Sobradinho e o Varjão. Lama ameaça invadir ribeirão chegar até o Lago Paranoá.

Desastre(s) Natural(is) associado(s) à reportagem: Erosão, movimento de massa.

Região(ões) Administrativa(s) afetada(s): Varjão (RA XXIII), Sobradinho (RA V).

Referência bibliográfica: MADER, Helena. Cratera ameaça ribeirão e casas. Correio Braziliense, Brasília, 10 de mar. de 2009. Cidades, p. 26.

\begin{tabular}{|c|c|c|c|}
\hline \multicolumn{4}{|c|}{ Notícia $n \div 4$} \\
\hline Dia: 28 & Página: 38 & Caderno: Cidades & Possui Fotos: Sim \\
\hline \multicolumn{4}{|c|}{ Título: Nascentes do Plano sob ameaça } \\
\hline \multicolumn{4}{|c|}{$\begin{array}{l}\text { Informações adicionais: Na lagoa do Parque de Uso Múltiplo da } 613 / 614 \text { da Asa Sul } \\
\text { enxurrada criada pela chuva carrega terra e toda sorte de dejetos das vias para a } \\
\text { lagoa. No Parque Olhos D’Água, na } 212 / 213 \text { Norte, a água da chuva escorre das ruas } \\
\text { desce carregando o que encontra pela frente e desembocando na nascente, gerando } \\
\text { uma série de erosões. }\end{array}$} \\
\hline \multicolumn{4}{|c|}{ Desastre(s) Natural(is) associado(s) à reportagem: Enxurrada, erosão. } \\
\hline \multicolumn{4}{|c|}{ Região(ões) Administrativa(s) afetada(s): Brasília (RA I). } \\
\hline $\begin{array}{l}\text { Referênc } \\
\text { Correio } B\end{array}$ & $\begin{array}{l}\text { liográfica: } \\
\text { nse, Brasília }\end{array}$ & $\begin{array}{l}\text { ANO, Izabel. Nascen } \\
\text { e mar. de 2009. Cida }\end{array}$ & no sob ameaça. \\
\hline
\end{tabular}

Abril

\begin{tabular}{|c|c|c|c|}
\hline \multicolumn{4}{|c|}{ Notícia n 5} \\
\hline Dia: 07 & Página: 28 & Caderno: Cidades & Possui Fotos: Sim \\
\hline \multicolumn{4}{|c|}{ Título: Chuva intensa causa transtornos } \\
\hline \multicolumn{4}{|c|}{$\begin{array}{l}\text { Informações adicionais: Apenas nos primeiros seis dias de abril choveu mais do que } \\
\text { todo o mês anterior, cerca de } 105 \mathrm{~mm} \text {, contra } 85 \mathrm{~mm} \text { de março, de acordo com o } \\
\text { INMET. Chuva causou alagamentos em Vicente Pires e Taguatinga. No condomínio }\end{array}$} \\
\hline
\end{tabular}


Privê, na Ceilândia, erosão aumenta e ameaça moradores.

Desastre(s) Natural(is) associado(s) à reportagem: Alagamento, erosão.

Região(ões) Administrativa(s) afetada(s): Ceilândia (RA IX), Taguatinga (RA III) e Vicente Pires (RA XXX).

Referência bibliográfica: REBELLO, Pablo. Chuva intensa causa transtornos. Correio Braziliense, Brasília, 7 de abr. de 2009. Cidades, p. 28.

\begin{tabular}{|c|c|c|c|}
\hline \multicolumn{4}{|c|}{ Notícia nํ 6} \\
\hline Dia: 14 & Página: 25 & Caderno: Cidades & Possui Fotos: Sim \\
\hline \multicolumn{4}{|c|}{ Título: Águas de abril causam transtornos } \\
\hline \multicolumn{4}{|c|}{$\begin{array}{l}\text { Informações adicionais: Corpo de Bombeiros precisou de máquinas de sucção para } \\
\text { tirar água de garagens alagadas na W3 Norte. Em Águas Claras, um muro caiu com a } \\
\text { enxurrada. A água chegou a } 60 \mathrm{~cm} \text {. Em seis horas, entre as } 2 \mathrm{~h} \text { e as } 8 \mathrm{~h} \text {, choveu } 98,1 \\
\mathrm{~mm} \text {. Em } 13 \text { dias, o acumulado é de } 232,8 \mathrm{~mm}-100 \mathrm{~mm} \text { a mais que a média prevista } \\
\text { para o mês, de } 123,8 \mathrm{~mm} \text {. Sinal de que este pode ser o abril mais chuvoso da história. } \\
\text { Até hoje, o recorde pertence ao ano de } 1992 \text {. O Corpo de Bombeiros ainda registrou } \\
\text { outras } 11 \text { chamadas por alagamento. Quadras mais afetadas foram a } 210,311 \text { e } 511 \\
\text { Norte. }\end{array}$} \\
\hline \multicolumn{4}{|c|}{ Desastre(s) Natural(is) associado(s) à reportagem: Alagamento, enxurrada. } \\
\hline \multicolumn{4}{|c|}{ Região(ões) Administrativa(s) afetada(s): Brasília (RA IX), Águas Claras (RA XX). } \\
\hline
\end{tabular}

\section{Setembro}

\begin{tabular}{|l|c|c|c|}
\hline \multicolumn{3}{|c|}{ Notícia no 7 } \\
\hline Dia: 09 & Página: 32 & Caderno: Cidades & Possui Fotos: Sim \\
\hline Título: Chuva faz estragos & $\begin{array}{l}\text { Informações adicionais: Algumas ruas de Ceilândia ficaram alagadas. Em } \\
\text { Taguatinga choveu granizo e em Sobradinho o vento derrubou postes. }\end{array}$ \\
\hline $\begin{array}{l}\text { Desastre(s) Natural(is) associado(s) à reportagem: Alagamento, granizo e } \\
\text { vendaval. }\end{array}$ \\
\hline Região(ões) Administrativa(s) afetada(s): Ceilândia (RA IX), Sobradinho (RA V), \\
\hline
\end{tabular}


Taguatinga (RA III).

Referência bibliográfica: REDAÇÃO. Chuva faz estragos. Correio Braziliense, Brasília, 9 de set. de 2009. Cidades, p. 32.

Outubro

\begin{tabular}{|c|c|c|c|}
\hline \multicolumn{4}{|c|}{ Notícia nㅇ 8} \\
\hline Dia: 9 & Página: 27 & Caderno: Cidades & Possui Fotos: Sim \\
\hline \multicolumn{4}{|c|}{ Título: Temporal assusta } \\
\hline \multicolumn{4}{|c|}{$\begin{array}{l}\text { Informações adicionais: O temporal no início da tarde impressionou quem passava } \\
\text { por Águas Claras. Choveu granizo na região e muitos carros ficaram parados nas ruas } \\
\text { por conta do volume de água. }\end{array}$} \\
\hline \multicolumn{4}{|c|}{ Desastre(s) Natural(is) associado(s) à reportagem: Alagamento, granizo. } \\
\hline \multicolumn{4}{|c|}{ Região(ões) Administrativa(s) afetada(s): Águas Claras (RA XX). } \\
\hline $\begin{array}{l}\text { Referênc } \\
9 \text { de out. }\end{array}$ & $\begin{array}{l}\text { liográfica: } F \\
\text { 09. Cidades, }\end{array}$ & ÃO. Temporal assus & io Braziliense, Brasília, \\
\hline
\end{tabular}

\begin{tabular}{|c|c|c|c|}
\hline \multicolumn{4}{|c|}{ Notícia n 9} \\
\hline Dia: 12 & Página: 21 & Caderno: Cidades & Possui Fotos: Sim \\
\hline \multicolumn{4}{|c|}{ Título: Chuva e vento causam acidentes } \\
\hline \multicolumn{4}{|c|}{$\begin{array}{l}\text { Informações adicionais: Água da chuva alagou viaduto que liga Vicente Pires e } \\
\text { Águas Claras à EPTG e derrubou árvore em estrada no Gama, o que causou um } \\
\text { acidente automobilístico. Moradores de Taguatinga e Samambaia sofreram com o } \\
\text { granizo. Na Asa Norte, ruas ficaram alagadas e árvores caíram. }\end{array}$} \\
\hline \multicolumn{4}{|c|}{ Desastre(s) Natural(is) associado(s) à reportagem: Alagamento, granizo, vendaval. } \\
\hline \multicolumn{4}{|c|}{$\begin{array}{l}\text { Região(ões) Administrativa(s) afetada(s): Águas Claras (RA XX), Brasília (RA I), } \\
\text { Gama (RA II), Samambaia (RA II), Taguatinga (RA III), Vicente Pires (RA XXX). }\end{array}$} \\
\hline \multicolumn{4}{|c|}{$\begin{array}{l}\text { Referência bibliográfica: BOECHAT, Juliana. Chuva e vento causam acidentes. } \\
\text { Correio Braziliense, Brasília, } 12 \text { de out. de 2009. Cidades, p. } 21 \text {. }\end{array}$} \\
\hline
\end{tabular}

\section{Dezembro}

\section{Notícia nำ 10}

\begin{tabular}{l|l|l|l} 
Dia: 22 & Página: 34 & Caderno: Cidades & Possui Fotos: Sim
\end{tabular}


Título: Verão chega com muitas chuvas

Informações adicionais: Na Asa Sul, ruas ficaram alagadas e teve motorista que ficou ilhado dentro do próprio carro. A força dos ventos derrubou árvores e destelhou casas e prédios.

Desastre(s) Natural(is) associado(s) à reportagem: Alagamento, vendaval.

Região(ões) Administrativa(s) afetada(s): Brasília (RA I).

Referência bibliográfica: MEDEIROS, Luísa. Verão chega com muitas chuvas.

Correio Braziliense, Brasília, 22 de dez. de 2004. Cidades, p. 34.

\section{APÊNDICE XI}

Desastres Naturais relacionados às chuvas no Distrito Federal relatados no jornal Correio Braziliense no ano de 2010

Fevereiro 


\begin{tabular}{c|c|c|c|} 
Dia: 07 & Página: 30 & Caderno: Cidades & Possui Fotos: Sim \\
\hline
\end{tabular}

Título: Queda de árvores destrói carros.

Informações adicionais: Temporal ocasionou a queda de quatro árvores em Ceilândia, gerando prejuízos para os moradores que tiveram seus veículos destruídos pela força dos ventos. A chuva teve duração de 30 minutos.

Desastre(s) Natural(is) associado à reportagem: Vendaval.

Região(ões) Administrativa(s) afetada(s): Ceilândia (RA IX).

Referência bibliográfica: AMORIM, Diego. Queda de árvores destrói carros. Correio Braziliense, Brasília, 07 de fev. de 2010. Cidades, p. 30.

\section{Março}

\begin{tabular}{|c|c|c|c|}
\hline \multicolumn{4}{|c|}{ Notícia nㅇ 2} \\
\hline Dia: 30 & Página: 33 & Caderno: Cidades & Possui Fotos: Sim \\
\hline \multicolumn{4}{|c|}{ Título: Temporal castiga o centro de Brasília. } \\
\hline \multicolumn{4}{|c|}{$\begin{array}{l}\text { Informações adicionais: Em apenas } 30 \text { minutos de chuva foi alcançado a marca de } \\
47 \mathrm{~mm} \text { de água por metro quadrado. Sendo que em um dia choveu o referente ao mês } \\
\text { de fevereiro inteiro. Esse evento gerou vários problemas, como os alagamentos das } \\
\text { tesourinhas da } 302 \text { Norte e } 502 \text { Norte que geraram transtornos para a população. }\end{array}$} \\
\hline \multicolumn{4}{|c|}{ Desastre(s) Natural(is) associado(s) à reportagem: Alagamento. } \\
\hline \multicolumn{4}{|c|}{ Região(ões) Administrativa(s) afetada(s): Brasília (RA I). } \\
\hline \multicolumn{4}{|c|}{$\begin{array}{l}\text { Referência bibliográfica: CALCAGNO, Luiz. Temporal castiga o centro de Brasília. } \\
\text { Correio Braziliense, Brasília, } 30 \text { de mar. de } 2010 \text {. Cidades, p. } 33 .\end{array}$} \\
\hline
\end{tabular}

\begin{tabular}{|c|c|c|c|}
\hline \multicolumn{3}{|c|}{ Notícia no 3} \\
\hline Dia: 31 & Página: 33 & Caderno: Cidades & Possui Fotos: Sim \\
\hline \multicolumn{3}{|l|}{ Título: Acidentes em Taguatinga e família em risco na Estrutural. } \\
\hline
\end{tabular}


houveram problemas com alagamentos.

Desastre(s) Natural(is) associado(s) à reportagem: Alagamento.

Região(ões) Administrativa(s) afetada(s): Brasília (RA I), Taguatinga (RA III) e Cruzeiro (RA XI).

Referência bibliográfica: CALCAGNO, Luiz. Temporal castiga o centro de Brasília. Correio Braziliense, Brasília, 31 de mar. de 2010. Cidades, p. 33.

Abril

\begin{tabular}{|c|c|c|c|}
\hline \multicolumn{4}{|c|}{ Notícia n 4} \\
\hline Dia: 05 & Página: 21 & Caderno: Cidades & Possui Fotos: Sim \\
\hline \multicolumn{4}{|c|}{ Título: Mais chuvas, mais destruição. } \\
\hline \multicolumn{4}{|c|}{$\begin{array}{l}\text { Informações adicionais: O temporal que atingiu o DF, segundo o Inmet gerou fortes } \\
\text { pancadas de chuva em diversos pontos da Asa Norte, com índice pluviométrico de } \\
43,6 \text { milímetros, o que acabou provocando alagamentos e enxurradas na região. }\end{array}$} \\
\hline \multicolumn{4}{|c|}{ Desastre(s) Natural(is) associado(s) à reportagem: Alagamento, enxurrada. } \\
\hline \multicolumn{4}{|c|}{ Região(ões) Administrativa(s) afetada(s): Brasília (RA I) } \\
\hline \multicolumn{4}{|c|}{$\begin{array}{l}\text { Referência bibliográfica: TRINDADE, Naira; BOECHAT, Juliana; MEIRELES, Olivia. } \\
\text { Mais chuvas, mais destruição. Correio Braziliense, Brasília, } 05 \text { de abr. de } 2010 . \\
\text { Cidades, p. } 21 \text {. }\end{array}$} \\
\hline
\end{tabular}

\begin{tabular}{|c|c|c|c|}
\hline \multicolumn{4}{|c|}{ Notícia nำ 5} \\
\hline Dia: 06 & Página: 24 & Caderno: Cidades & Possui Fotos: Sim \\
\hline \multicolumn{4}{|c|}{ Título: Mais de um mês de água em cinco dias. } \\
\hline \multicolumn{4}{|c|}{$\begin{array}{l}\text { Informações adicionais: Volume de precipitações registrado ultrapassou 188mm, } \\
\text { superando a média esperada de } 132 \mathrm{~mm} \text {. Segundo a Defesa Civil, o número de } \\
\text { ocorrências não aumentou. }\end{array}$} \\
\hline \multicolumn{4}{|c|}{ Desastre(s) Natural(is) associado(s) à reportagem: Alagamento. } \\
\hline \multicolumn{4}{|c|}{ Região(ões) Administrativa(s) afetada(s): SCIA (RA XXV). } \\
\hline \multicolumn{4}{|c|}{$\begin{array}{l}\text { Referência bibliográfica: CALCAGNO, Luiz. Mais de um mês de água em cinco dias. } \\
\text { Correio Braziliense, Brasília, } 06 \text { de abr. de } 2004 \text {. Cidades, p. } 22 \text {. }\end{array}$} \\
\hline
\end{tabular}




\begin{tabular}{|c|c|c|c|}
\hline Dia: 07 & Página: 28 & Caderno: Cidades & Possui Fotos: Sim \\
\hline
\end{tabular}

Título: Áreas de risco aumentam.

Informações adicionais: Defesa Civil monitora 35 locais em todo o Distrito Federal onde podem ocorrer alagamentos e deslizamentos de

terra - número era de 25 , há 10 dias. Ontem à tarde, mais um temporal causou muitos transtornos para os brasilienses

Desastre(s) Natural(is) associado(s) à reportagem: Alagamento, movimentos de massa.

Região(ões) Administrativa(s) afetada(s): Brasília (RA IX), Vicente Pires (XXX), Ceilândia (RA IX), SCIA (RA XXV).

Referência bibliográfica: ARAÚJO, Saulo. Áreas de risco aumentam. Correio Braziliense, Brasília, 07 de abr. de 2010. Cidades, p. 28.

\begin{tabular}{|c|c|c|c|}
\hline \multicolumn{4}{|c|}{ Notícia nำ 7} \\
\hline Dia: 10 & Página: 31 & Caderno: Cidades & Possui Fotos: Sim \\
\hline \multicolumn{4}{|c|}{ Título: Sem soluções para os alagamentos. } \\
\hline \multicolumn{4}{|c|}{$\begin{array}{l}\text { Informações adicionais: Os temporais das últimas semanas evidenciaram um } \\
\text { problema conhecido da população, a insuficiência da rede de captação de águas } \\
\text { pluviais. Projeto do governo que pretende amenizar os danos aguarda liberação do } \\
\text { TCDF. }\end{array}$} \\
\hline \multicolumn{4}{|c|}{ Desastre(s) Natural(is) associado(s) à reportagem: Alagamento. } \\
\hline \multicolumn{4}{|c|}{$\begin{array}{l}\text { Região(ões) Administrativa(s) afetada(s): Brasília (RA I), Taguatinga (RA III), } \\
\text { Ceilândia (RA IX). }\end{array}$} \\
\hline \multicolumn{4}{|c|}{$\begin{array}{l}\text { Referência bibliográfica: MADER, Helena. Sem soluções para os alagamentos. } \\
\text { Correio Braziliense, Brasília, } 10 \text { de abr. de } 2010 \text {. Cidades, p. } 31 \text {. }\end{array}$} \\
\hline
\end{tabular}

\section{Setembro}

\begin{tabular}{|c|c|c|c|}
\hline \multicolumn{3}{|c|}{ Notícia no } \\
\hline Dia: 28 & Página: 18 & Caderno: Opinião & Possui Fotos: Sim \\
\hline \multicolumn{2}{|l|}{} \\
\hline \multicolumn{2}{|l|}{} \\
\hline
\end{tabular}


Informações adicionais: Os problemas decorrentes com os alagamentos que afetam as regiões do Distrito Federal são recorrentes todos os anos e necessitam maior atenção dos entes governamentais.

Desastre(s) Natural(is) associado(s) à reportagem: Alagamento.

Região(ões) Administrativa(s) afetada(s): Brasília (RA I).

Referência bibliográfica: REDAÇÃO. Chuvas no DF exigem medidas preventivas. Correio Braziliense, Brasília, 28 de set. de 2010. Cidades, p. 18.

\section{Notícia nำ 9}

\begin{tabular}{|c|c|c|c|}
\hline Dia: 29 & Página: 35 & Caderno: Cidades & Possui Fotos: Sim \\
\hline
\end{tabular}

Título: Seja bem-vinda chuva.

Informações adicionais: Com a chegada da estação chuvosa no DF, são alertados aos problemas decorrentes com os alagamentos, vendavais sempre frequentes em diversos pontos da cidade.

Desastre(s) Natural(is) associado(s) à reportagem: Alagamento, enxurrada, vendaval.

Região(ões) Administrativa(s) afetada(s): São Sebastião (RA XIV).

Referência bibliográfica: ALVES, Renato Seja bem-vinda chuva. Correio Braziliense, Brasília, 29 de set. de 2010. Cidades, p. 35.

\section{Outubro}

\begin{tabular}{|c|c|c|c|}
\hline \multicolumn{4}{|c|}{ Notícia nํ 10} \\
\hline Dia: 20 & Página: 29 & Caderno: Cidades & Possui Fotos: Sim \\
\hline \multicolumn{4}{|c|}{ Título: Estragos começaram cedo. } \\
\hline \multicolumn{4}{|c|}{$\begin{array}{l}\text { Informações adicionais: Muros derrubados, queda de energia e bens destruídos } \\
\text { foram algumas consequências das primeiras precipitações } \\
\text { após fim da estação seca no DF. }\end{array}$} \\
\hline \multicolumn{4}{|c|}{ Desastre(s) Natural(is) associado(s) à reportagem: Alagamento, enxurrada. } \\
\hline \multicolumn{4}{|c|}{$\begin{array}{l}\text { Região(ões) Administrativa(s) afetada(s): Taguatinga (RA III), Ceilândia (RA IX), } \\
\text { Vicente Pires (RA XXX). }\end{array}$} \\
\hline
\end{tabular}


Braziliense, Brasília, 20 de out. de 2010. Cidades, p. 29.

\section{Notícia no 11}

\begin{tabular}{|c|c|c|c|}
\hline Dia: 28 & Página: 46 & Caderno: Cidades & Possui Fotos: Sim \\
\hline
\end{tabular}

Título: Licitação pública fora de hora.

Informações adicionais: Iniciada a dois meses do fim do governo, concorrência para obras de escoamento de água das chuvas e pavimentação na Asa Norte e em Taguatinga tem edital de pré-qualificação com critérios que beneficiariam grupo seleto de empresas.

Desastre(s) Natural(is) associado(s) à reportagem: Alagamento, enxurrada.

Região(ões) Administrativa(s) afetada(s): Brasília (RA I), Taguatinga (RA III)

Referência bibliográfica: TAHAN, Lilian. Licitação pública fora de hora. Correio Braziliense, Brasília, 28 de out. de 2010. Cidades, p. 46.

\section{Novembro}

\begin{tabular}{|c|c|c|c|}
\hline \multicolumn{4}{|c|}{ Notícia nº 12} \\
\hline Dia: 04 & Página: 35 & Caderno: Cidades & Possui Fotos: Sim \\
\hline \multicolumn{4}{|c|}{ Título: Áreas de risco no DF. } \\
\hline \multicolumn{4}{|c|}{$\begin{array}{l}\text { Informações adicionais: Defesa Civil do Distrito Federal divulgou ontem balanço das } \\
\text { regiões de risco na capital federal. As residências das famílias } \\
\text { instaladas em } 26 \text { áreas são monitoradas. Sendo estas apresentadas com casos de } \\
\text { erosões, e emitindo sinais de alerta para as famílias próximas. }\end{array}$} \\
\hline \multicolumn{4}{|c|}{ Desastre(s) Natural(is) associado(s) à reportagem: Erosões. } \\
\hline \multicolumn{4}{|c|}{ Região(ões) Administrativa(s) afetada(s): Sobradinho II (RA XXVI) } \\
\hline $\begin{array}{l}\text { Referênci } \\
\text { Brasília, } 0\end{array}$ & $\begin{array}{l}\text { ibliográfica: } R \\
\text { e nov. de } 2010 \text {. }\end{array}$ & $\begin{array}{l}\text { ÂO. Áreas de risco } \\
\text { des, p. } 35 .\end{array}$ & Correio Braziliense, \\
\hline
\end{tabular}

\begin{tabular}{|c|c|c|c|}
\hline \multicolumn{3}{|c|}{ Notícia no 13 } \\
\hline Dia: 05 & Página: 30 & Caderno: Cidades & Possui Fotos: Sim \\
\hline \multicolumn{2}{|l|}{ Título: Chuva ameaça 26 áreas. } \\
\hline
\end{tabular}


Informações adicionais: Defesa Civil do Distrito Federal divulgou ontem balanço das regiões de risco na capital federal. As residências das famílias

instaladas em 26 áreas são monitoradas.

Desastre(s) Natural(is) associado(s) à reportagem: Alagamento, erosões.

Região(ões) Administrativa(s) afetada(s): Sobradinho II (RA XXVI), Vicente Pires (RA XXX).

Referência bibliográfica: CALCAGNO, Luiz. Chuva ameaça 26 áreas. Correio Braziliense, Brasília, 05 de nov. de 2010. Cidades, p. 30.

\begin{tabular}{|c|c|c|c|}
\hline \multicolumn{4}{|c|}{ Notícia n 14} \\
\hline Dia: 23 & Página: 28 & Caderno: Cidades & Possui Fotos: Sim \\
\hline \multicolumn{4}{|c|}{ Título: Chuva e fogo ao cair da tarde. } \\
\hline \multicolumn{4}{|c|}{$\begin{array}{l}\text { Informações adicionais: A forte chuva de ontem trouxe transtornos aos brasilienses. } \\
\text { Houve alagamentos em vários pontos, como na tesourinha da } 203 \text { Norte (D), e os } \\
\text { motoristas tiveram que empurrar os carros danificados. }\end{array}$} \\
\hline \multicolumn{4}{|c|}{ Desastre(s) Natural(is) associado(s) à reportagem: Alagamento. } \\
\hline \multicolumn{4}{|c|}{ Região(ões) Administrativa(s) afetada(s): Brasília (RA I). } \\
\hline $\begin{array}{l}\text { Referênci } \\
\text { Braziliens }\end{array}$ & $\begin{array}{l}\text { bliográfica: } \\
\text { asília, } 23 \text { de }\end{array}$ & $\begin{array}{l}\text { ÂO. Chuva e fogo a } \\
\text { 2010. Cidades, p. } 2\end{array}$ & tarde. Correio \\
\hline
\end{tabular}

